
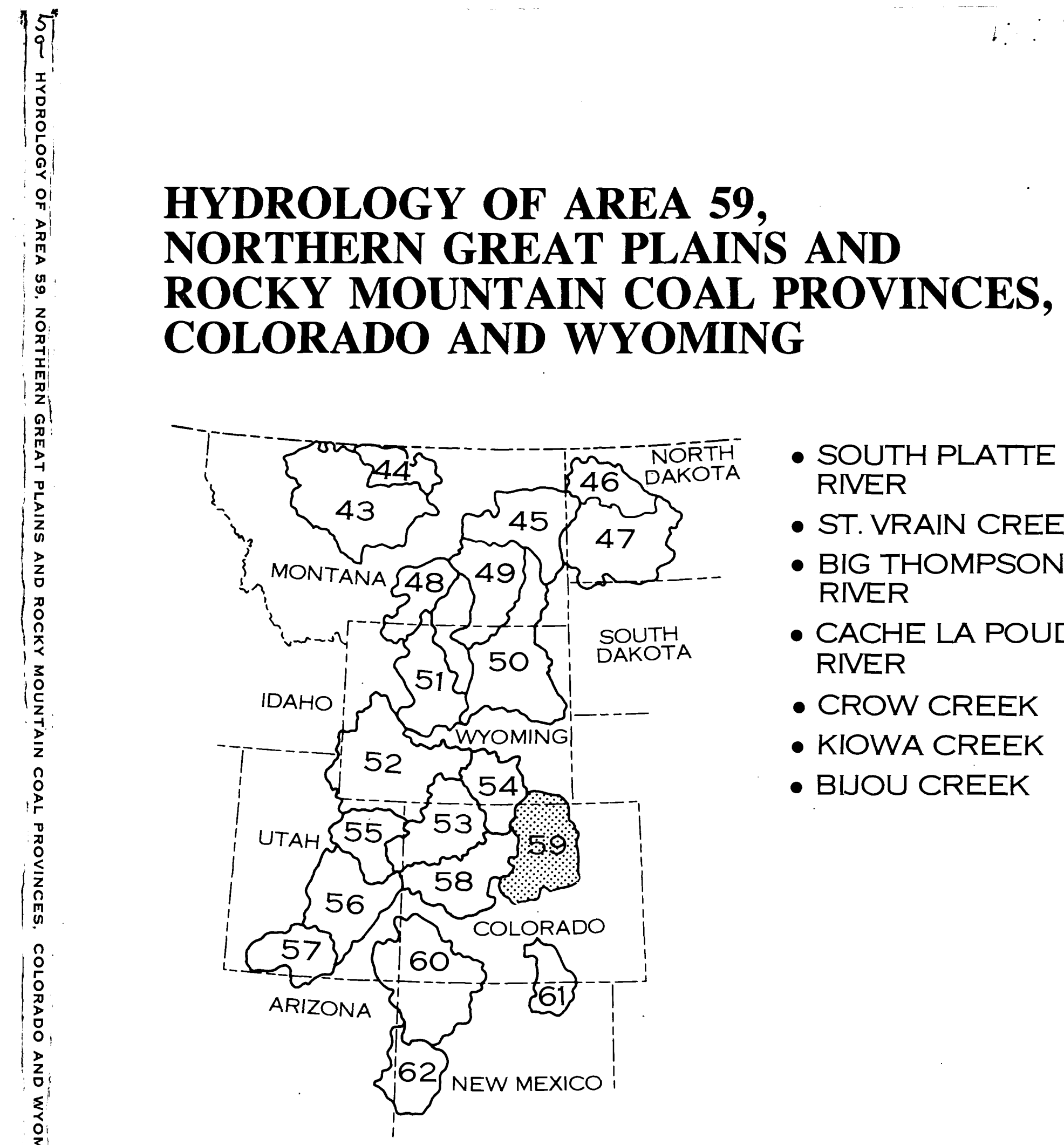

- SOUTH PLATTE RIVER

- ST. VRAIN CREEK

- BIG THOMPSON RIVER

- CACHE LA POUDRE RIVER

- CROW CREEK

- KIOWA CREEK

- BIJOU CREEK

UNITED STATES DEPARTMENT OF THE INTERIOR GEOLOGICAL SURVEY OPEN-FILE REPORT 85-153 


\section{HYDROLOGY OF AREA 59, NORTHERN GREAT PLAINS AND ROCKY MOUNTAIN COAL PROVINCES, COLORADO AND WYOMING}

BY

NEVILLE G. GAGGIANI, LINDA J. BRITTON, DONALD R. MINGES, AND OTHERS

U.S. GEOLOGICAL SURVEY

WATER-RESOURCES INVESTIGATIONS

OPEN-FILE REPORT 83-153

LAKEWOOD, COLORADO

JANUARY 1987 


\section{DEPARTMENT OF THE INTERIOR}

DONALD PAUL HODEL, SECRETARY

\section{UNITED STATES GEOLOGICAL SURVEY}

Dallas. L. Peck, Director

For additional information write to:

District Chief

U.S. Geological Survey

Water Resources Division

Bldg. 53, Denver Federal Center

Mail Stop 415, Box 25046

Lakewood, Colorado 80225 


\section{CONTENTS}

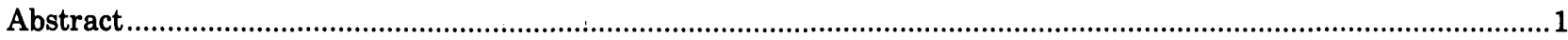

1.0 Introduction

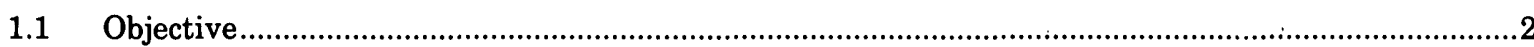

F. A. Kilpatrick

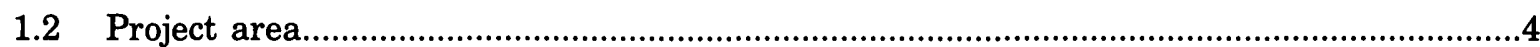

Neville G. Gaggiani

1.3 Hydrologic problems related to surface mining

Randolph S. Parker

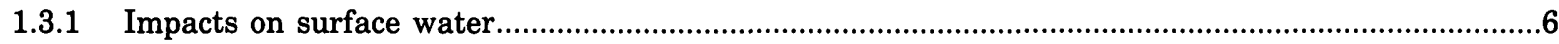

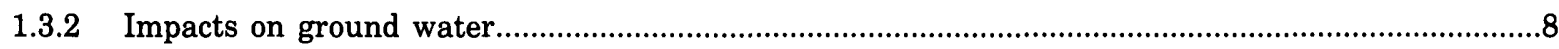

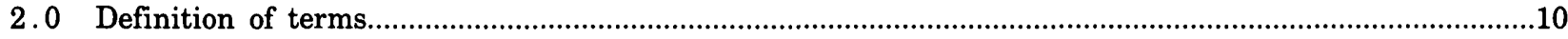

3.0 General features

Neville G. Gaggiani

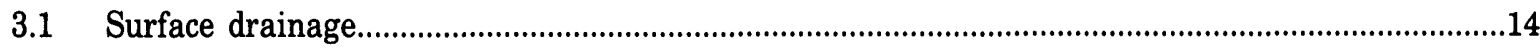

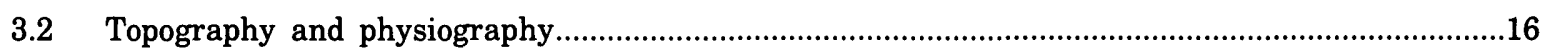

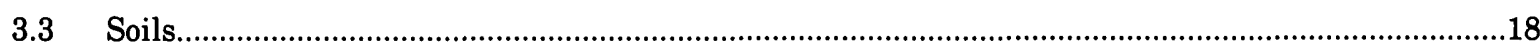

3.4 Geology

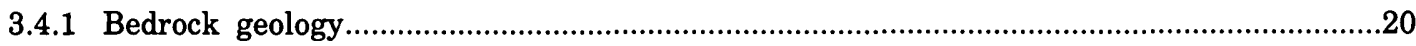

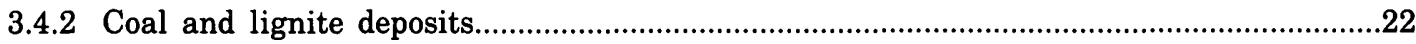

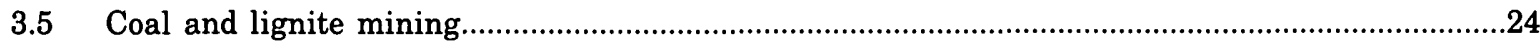

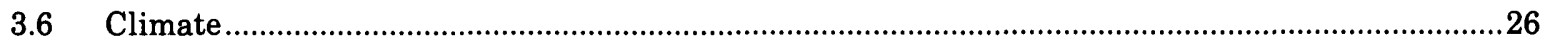

4.0 Water use

Linda J. Britton

4.1 Classification of surface water based on recreational, water supply, and

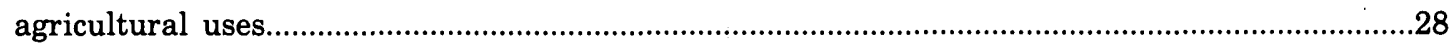

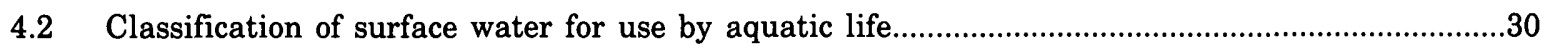

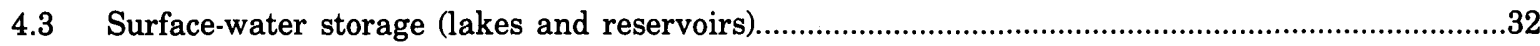

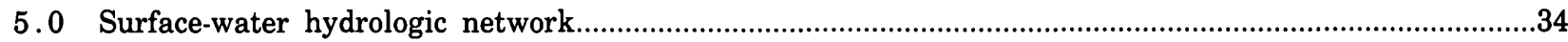

Neville G. Gaggiani 
6.0 Surface-water quantity

Donald $R$. Minges

6.1 Streamflow variability

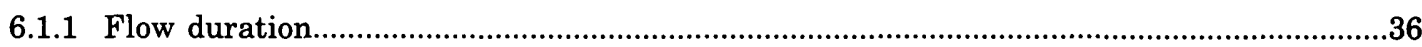

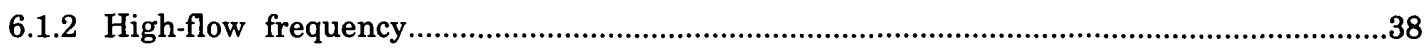

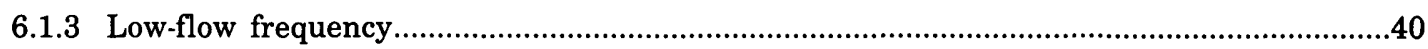

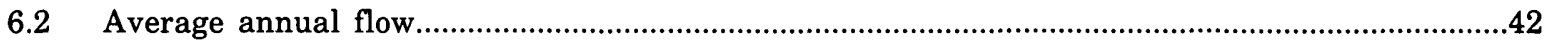

$6.3 \quad$ Floods

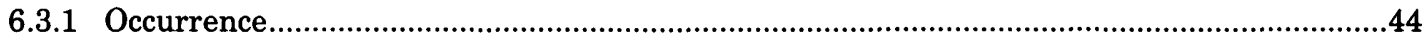

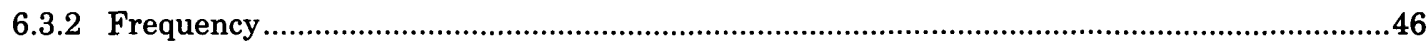

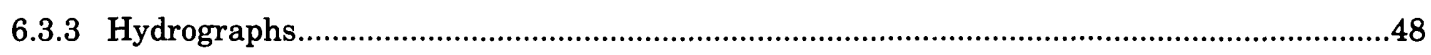

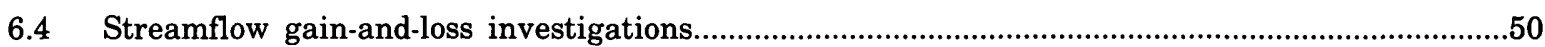

7.0 Surface-water quality

Linda J. Britton

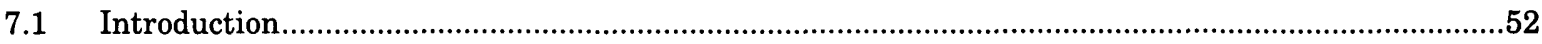

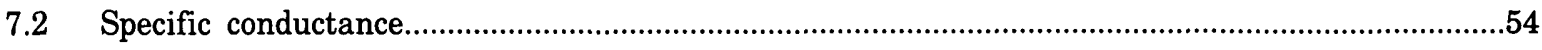

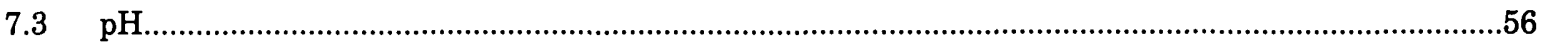

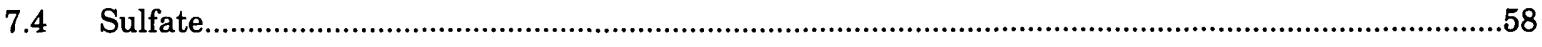

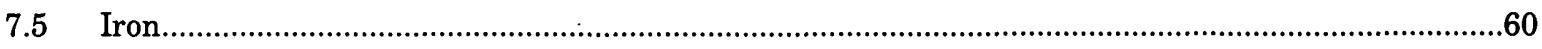

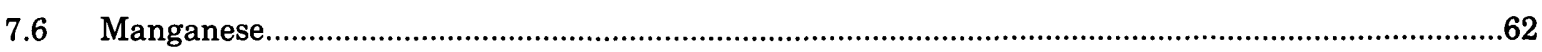

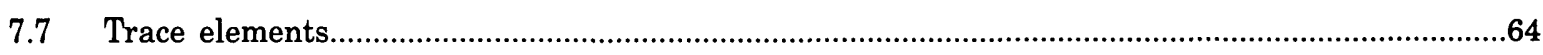

8.0 Sediment

James E. Kircher

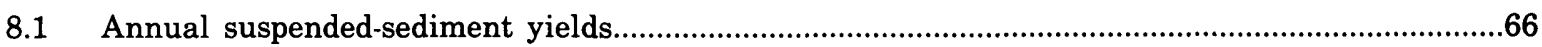

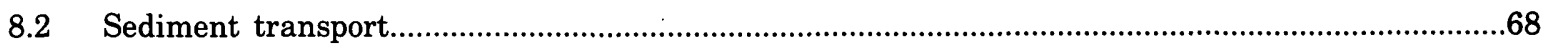

9.0 Ground water

Neville G. Gaggiani

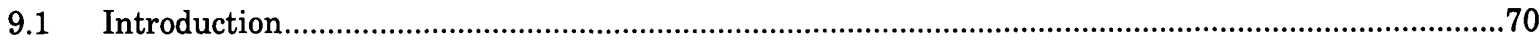


9.2 Availability. .72

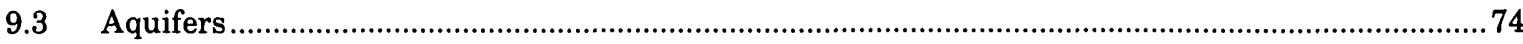

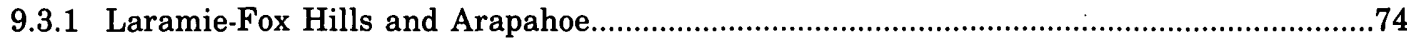

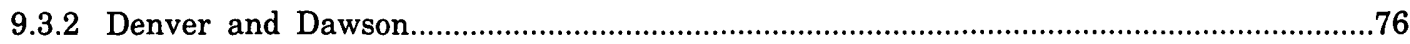

10.0 Ground-water quality

Neville G. Gaggiani

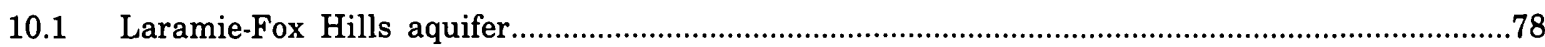

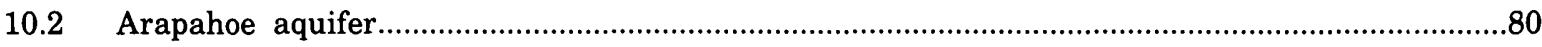

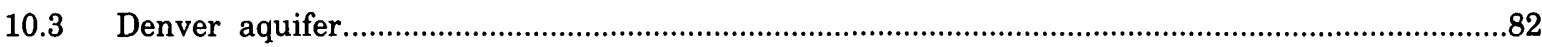

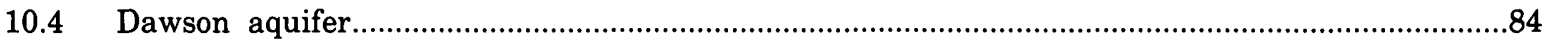

11.0 Water-data sources

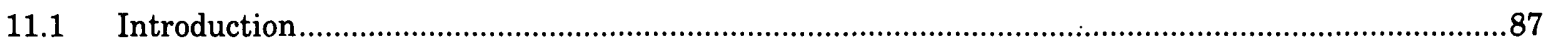

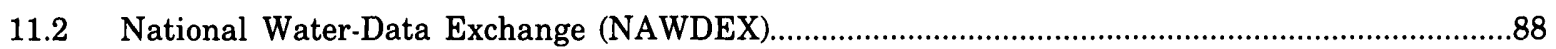

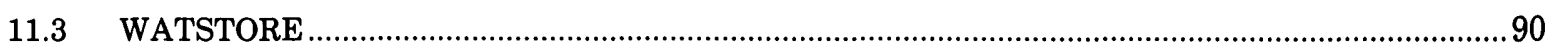

11.4 Index to water-data activities in coal provinces................................................................92

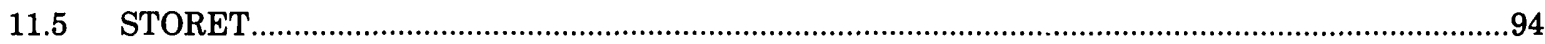

12.0 Supplemental information

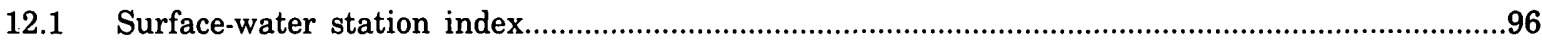

12.2 Summary of surface areas, capacities, and uses of selected lakes and reservoirs....................107

12.3 Specific conductance of water samples from selected surface-water stations............................110

12.4 Trace-element concentrations in water samples from selected surface-water stations exceeding recommended water-quality criteria.

13.0 References

13.1 References cited.

13.2 Selected references 


\section{FACTORS FOR CONVERTING INCH-POUND UNITS TO INTERNATIONAL SYSTEM OF UNITS (SI)}

For the convenience of readers who may want to use the International System of Units (SI), the data may be converted by using the following factors:

Multiply inch-pound units

acre-feet (acre-ft)

cubic feet per second $\left(\mathrm{ft}^{3} / \mathrm{s}\right)$

cubic feet per second per mile $\left[\left(\mathrm{ft}^{3} / \mathrm{s}\right) / \mathrm{mi}\right]$

cubic feet per second per square mile $\left[\left(\mathrm{ft}^{3} / \mathrm{s}\right) / \mathrm{mi}^{2}\right]$

feet $(\mathrm{ft})$

feet per mile (ft/mi)

acre feet per square mile per year [(acre-ft/mi $\left.\left.{ }^{2}\right) / \mathrm{yr}\right]$

gallons per minute (gal/min)

gallons per minute per square mile $\left[(\mathrm{gal} / \mathrm{min}) / \mathrm{mi}^{2}\right]$

inches (in.)

inches per hour (in/h)

micromhos per centimeter at $25^{\circ}$ Celsius $\left(\mu \mathrm{ho} / \mathrm{cm}\right.$ at $\left.25^{\circ} \mathrm{C}\right)$

miles (mi)

square miles $\left(\mathrm{mi}^{2}\right)$

tons, short $\underset{1,233}{\text { By }}$

0.02832

0.01760

0.01093

0.3048

0.1894

476.1

0.06309

0.02436

25.4

25.4

2.54

100

1.609

2.590

0.9078
To obtain SI units

cubic meters $\left(\mathrm{m}^{3}\right)$

cubic meters per second $\left(\mathrm{m}^{3} / \mathrm{s}\right)$

cubic meters per second per kilometer $\left[\left(\mathrm{m}^{3} / \mathrm{s}\right) / \mathrm{km}\right]$

cubic meters per second per square kilometer $\left[\left(\mathrm{m}^{3} / \mathrm{s}\right) / \mathrm{km}^{2}\right]$

meters (m)

meters per kilometer $(\mathrm{m} / \mathrm{km})$

cubic meters per square kilometer per year $\left.\left[\mathrm{m}^{3} / \mathrm{km}^{2}\right) / \mathrm{a}\right]$

liters per second $(\mathrm{L} / \mathrm{s})$

liters per second per square kilometer $\left[(\mathrm{L} / \mathrm{s}) / \mathrm{km}^{2}\right]$

millimeters (mm)

millimeters per hour $(\mathrm{mm} / \mathrm{h})$ centimeters per hour $(\mathrm{cm} / \mathrm{h})$

microsiemens per meter at $25^{\circ}$ Celsius $\left(\mathrm{S} / \mathrm{m}\right.$ at $25^{\circ} \mathrm{C}$ )

kilometers (km)

square kilometers $\left(\mathrm{km}^{2}\right)$

tons, metric $(\mathrm{t})$

$$
{ }^{\circ} \mathrm{F}=1.8 \times{ }^{\circ} \mathrm{C}+32
$$




\title{
HYDROLOGY OF AREA 59, NORTHERN GREAT PLAINS AND ROCKY MOUNTAIN COAL PROVINCES, COLORADO AND WYOMING
}

BY

NEVILLE G. GAGGIANI, LINDA J. BRITTON, DONALD R. MINGES, AND OTHERS

\begin{abstract}
Hydrologic information and analysis aid in decisions to lease federally owned coal and to prepare necessary Environmental Assessments and Impact Study reports. This need has become even more critical with the enactment of Public Law 95-87, the "Surface Mining Control and Reclamation Act of 1977." This act requires an appropriate regulatory agency to issue permits, based on the review of permit-application data to assess hydrologic impacts. This report, which partially fulfills this requirement, is one in a series of nationwide coal province reports that present information thematically, through the use of a brief text and accompanying maps, graphs, charts, or other illustrations for single hydrologic topics. The report broadly characterizes the hydrology of Area 59 in north-central Colorado and southeastern Wyoming.

The report area, located within the South Platte River basin, covers a 16,000-square-mile area of diverse geology, topography, and climate. This diversity results in contrasting hydrologic characteristics.

The South Platte River, the major stream in the area, and most of its tributaries originate in granitic mountains and flow into and through the sedimentary rocks of the Great Plains. Altitudes range from less than 5,000 feet to more than 14,000 feet above sea level. Precipitation in the mountains may exceed 40 inches annually, much of it during the winter, and produces deep snowpacks. Snowmelt during the spring and summer produces most streamflow. Transmountain diversion of water from the streams on the western slope of the mountains also adds to the streamflow. Precipitation in the plains is as little as 10 inches annually. Streams that originate in the plains are ephemeral.

Streamflow quality is best in the mountains, where dissolved-solids concentrations are generally small. Concentrations increase in the plains as streams flow through sedimentary basins, and as urbanization and irrigation increase. The quality of some mountain streams is affected by drainage from previous metalmining areas, as indicated by greater trace-element concentrations and smaller $\mathrm{pH}$ values. However, the large

trace-element concentrations decrease rapidly downstream from the metal-mining areas. Because the climate is semiarid in most of the area, the soils are not adequately leached; therefore, flows in ephemeral streams usually have larger concentrations of dissolved solids than flows in perennial streams.

Ground water is available throughout the area; yields range from less than 0.1 gallons per minute in the fractured granite aquifer in the mountains to more than 2,000 gallons per minute in the alluvial aquifer of the South Platte River valley. Major bedrock aquifers in order of decreasing age are the Laramie-Fox Hills, Arapahoe, Denver, and Dawson; these aquifers are used for municipal, domestic, and livestock supplies. Alluvial aquifers supply the high-yield irrigation wells.

The best quality ground water is found at the center of the major bedrock aquifers, where dissolved-solids concentrations are less than 200 milligrams per liter. The poorest-quality water is usually found near the edges of these aquifers. Water in the coal-bearing Laramie and Denver Formations is locally affected by coal deposits, causing dissolved-solids concentrations to be relatively large.

Only one coal mine is now operating in Area 59, the Coors Energy Company surface coal mine, which produced 100,000 short tons of subbituminous coal from the Upper Cretaceous Laramie Formation in 1982. Past coal-mining operations removed more than 130 million tons of coal and lignite from Area 59, 99 percent of which came from underground mines. The largest coal production was in Weld and Boulder Counties, Colorado.

Hydrologic problems related to surface mining are erosion, sedimentation, decline in water levels, disruption of aquifers, and degradation of water quality. Because the semiarid mine areas have very little runoff, and the major streams have large buffer and dilution capacities, the effects of mining on surface water is minimal. However, effects on ground water may be much more severe and long-lasting.
\end{abstract}




\title{
1.0 INTRODUCTION \\ 1.1 Objective
}

\section{Report Summarizes Available Hydrology Data}

\author{
Existing hydrologic conditions and sources of information are identified to aid \\ leasing decisions, preparation of Environmental Impact studies, \\ and evaluation of mine-permit applications.
}

Hydrologic information and analysis aid in decisions to lease federally owned coal and to prepare necessary Environmental Assessments and Impact Study reports. This need has become even more critical with the enactment of Public Law 95-87, the "Surface Mining Control and Reclamation Act of 1977." This Act requires an appropriate regulatory agency to issue mining permits, based on the review of permit-application data to assess hydrologic impacts. This need is partly fulfilled by this report, which broadly characterizes the hydrology of Area 59 in Colorado and Wyoming, a part of the Northern Great Plains and Rocky Mountain Coal Provinces (fig. 1.1-1). This report is one of a series that describes coal provinces nationwide.

This report provides general hydrologic information thematically, through the use of a brief text and accompanying maps, charts, graphs, or other illustrations, for each of a series of water-resources- related topics. All of the topical discussions taken together provide a description of the hydrology of the area. This information will be useful to Federal agencies in the leasing and management of Federal coal lands, to surface-mine owners, operators, and others preparing permit applications, and to regulatory authorities evaluating the adequacy of the applications.

The hydrologic information presented herein, or available through sources identified in this report, will be useful in describing the hydrology of the "general area" of any proposed mine. This hydrologic information will be supplemented by the lease applicant's site-specific data, as well as data from other sources. The purpose of the sitespecific data is to provide a detailed appraisal of the hydrology of the area in the vicinity of the mine, and the anticipated hydrologic consequences of the mining operation. 


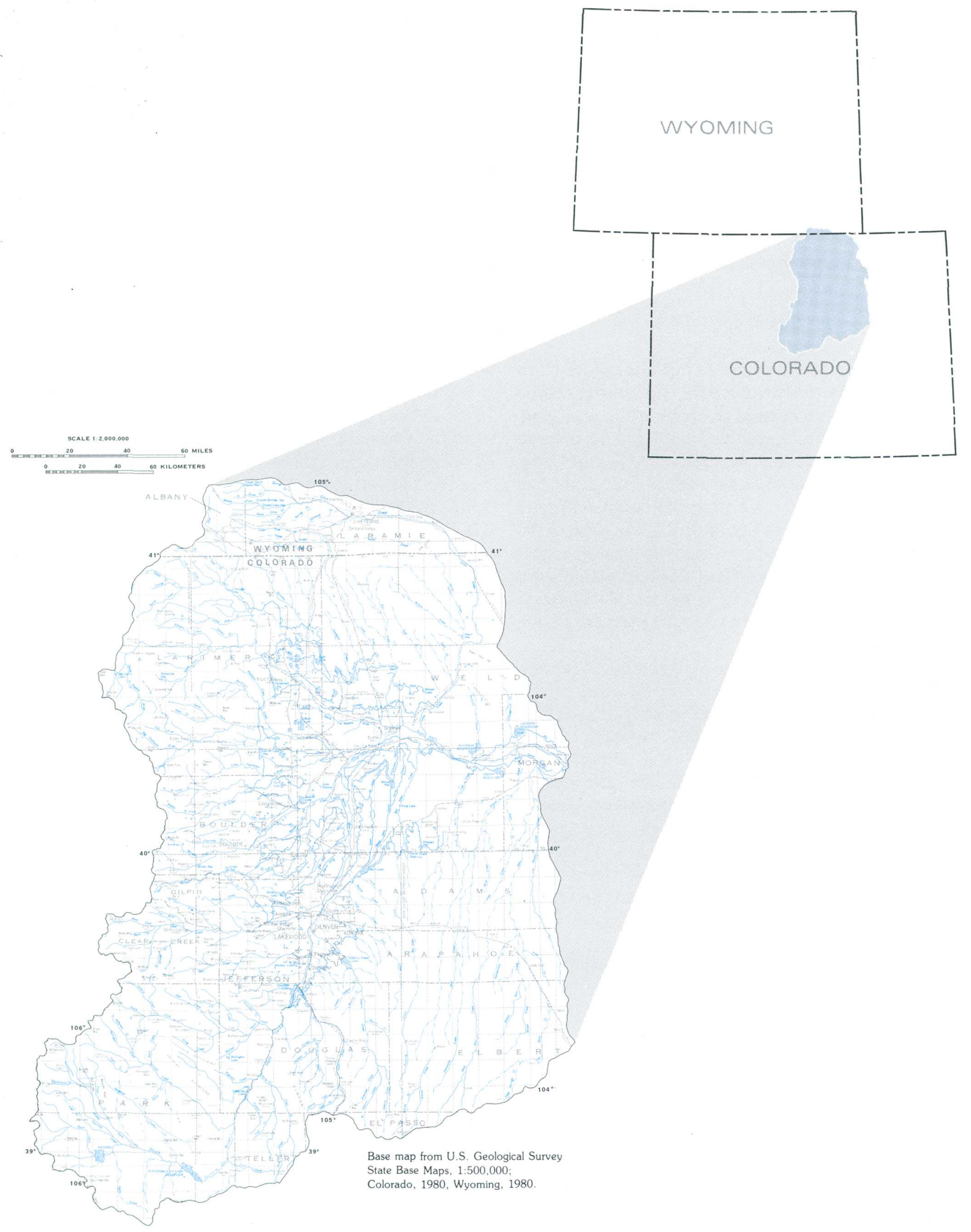

Figure 1.1-1 Location of Coal Area 59. 


\title{
1.0 INTRODUCTION--Continued \\ 1.2 Project Area
}

\section{Area 59 Covers Parts of Colorado and Wyoming}

\author{
Most of the population of Colorado and some of \\ its best farm land is found in Area 59
}

\begin{abstract}
All or part of 15 counties in Colorado and 2 in Wyoming are within Area 59 (fig. 1.2-1). These counties contain most of the population and some of the best farmlands in Colorado, and a large population center in Wyoming. Although very little coal is produced in Area 59, Denver, Colo. has many energy companies, probably because Denver is a desirable place to live, and is fairly close to the energy deposits (coal, oil shale, natural gas, and uranium) located throughout the Rocky Mountain region outside of Area 59. In the coal fields inside Area 59, only low-grade coal and lignite are found.

Most of the population in Area 59 is concentrated in the Front Range Urban Corridor which runs north and south of Denver, Colo. (fig. 1.2-1). The development of this population center has been stimulated by a relatively mild climate, the availability of good-quality surface and ground water, the accessibility of the energy and mineral deposits of the Rocky Mountains, the development of a major transportation center (Denver, Colo.) and the attraction of both summer and winter outdoor activities, such as hiking and skiing in the nearby Rocky Mountains.
\end{abstract}

According to the U.S. Census Bureau (1982), Denver, Colo., and cities nearby have the bulk of the population in the area. Cheyenne, Wyo., has the largest population in the Wyoming part of Area 59. In the eastern and western halves of the area, towns are small and far apart. Populations of some towns in the Front Range Urban Corridor in 1980 were: Denver, 1,352,070; Boulder, 81,239; Fort Collins, 78,287; and Greeley, 62,297. Cheyenne, Wyo., which is north of the urban corridor, is also a major population center, and had a population of 47,207 in 1980 . In the eastern part of the area, the population of the Kiowa area in 1980 was 5,202.

In the western part of the area, the town of Estes Park in Larimer County had a population of 2,703 in 1980, and the town of Fairplay in Park County had a population of 421 .

The less-populated eastern and western parts of Area 59 are quite different from each other; agriculture is the major industry in the east; recreation is the major industry in the west. Natural gas and petroleum reserves and small uranium and coal reserves characterize mineral deposits in the east; gold, silver, and molybdenum are important mineral deposits in the west. 


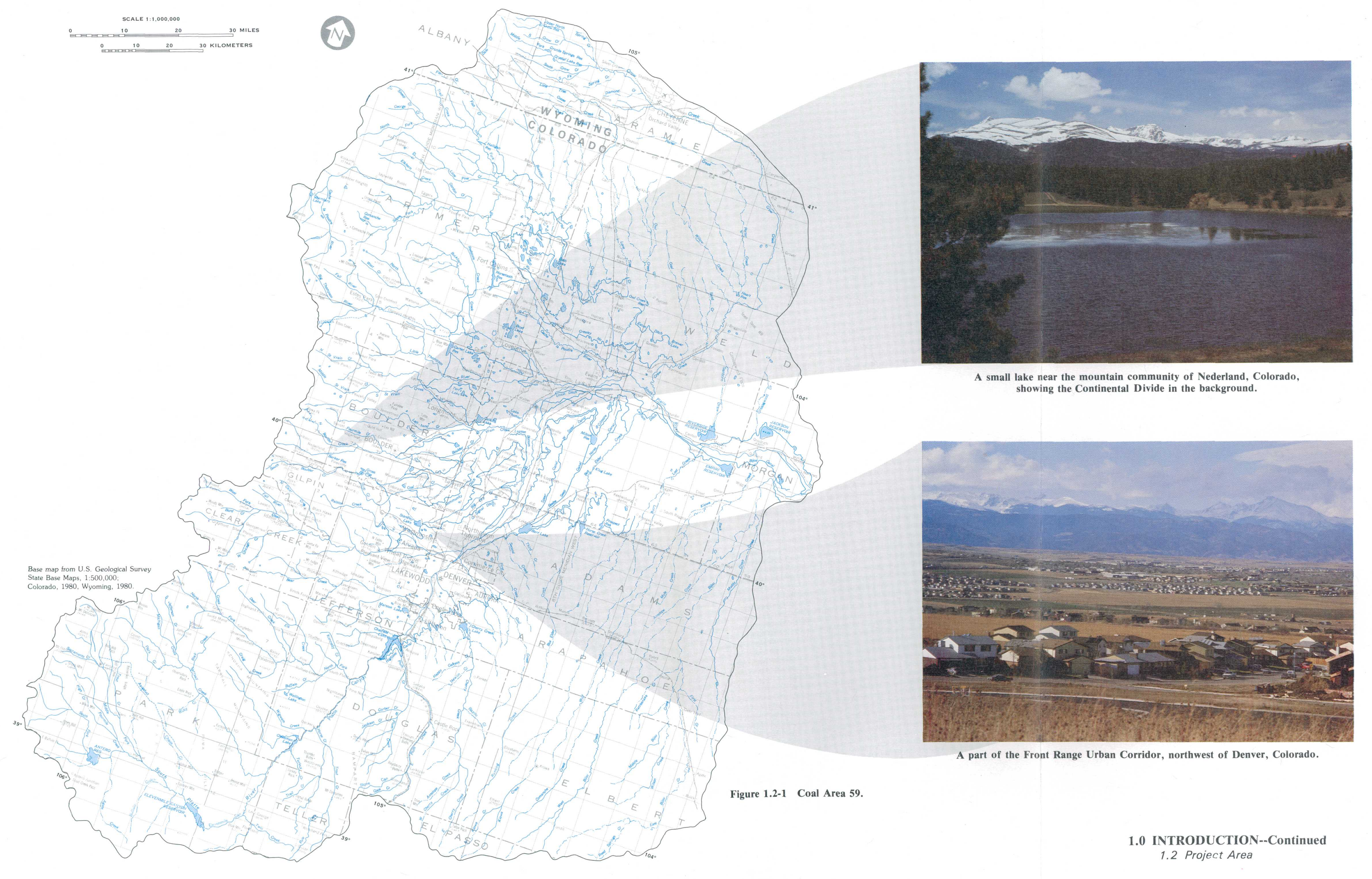




\title{
1.0 INTRODUCTION--Continued \\ 1.3 Hydrologic Problems Related to Surface Mining \\ 1.3.1 Impacts on Surface Water
}

\section{Quality of Surface Water Can be Degraded}

\author{
Erosion, sedimentation, and degradation of surface-water quality \\ are typical problems associated with surface coal mining.
}

Surface mining results in dramatic changes, at least temporarily, in the landscape of previously undisturbed land. Landscape changes, such as removal of vegetation through excavation, and formation of large areas of unconsolidated and unweathered spoil material will result in changes in the hydrologic characteristics of the mine areas (fig. 1.3.1-1). Hydrologic changes can affect the amounts of suspended sediment carried by streams, and the amounts of dissolved solids, and dissolved or total recoverable trace elements in surface water.

The hydrologic setting of Area 59, with respect to coal mining, is somewhat similar to that of other coal areas in the Rocky Mountain Coal Province. The major rivers-the South Platte River and its principal tributaries-have headwaters in mountains some distance from the coal areas; whereas streams that originate in the coal areas are ephemeral. These mountains supply most of the water to the river systems from deep snowpacks that melt during late spring and summer. The mountains, generally igneous and metamorphic rock, are very different geologically from the coal areas, which are in sedimentary rock. Most of the water and its associated quality is foreign to the coal-region environment through which the water is transported. These factors, in part, help reduce adverse impacts from mining, because runoff from the mine areas is relatively small, and larger streams usually have a large dilution capacity. However, observation of the system is more difficult, because both the major streams and the small tributaries draining the coal areas must be observed.

A characteristic of ephemeral streams in this area is that they often have larger concentrations of suspended sediment than perennial streams do (fig. 1.3.1-2). Loss of vegetative cover and formation of areas of unconsolidated spoil material provide some opportunity for increased suspended-sediment concentrations in these streams. These areas are especially susceptible to increased erosion during occasional intense thunderstorms. Because of overall lack of water in these streams, the potential for increased sediment yield usually can be controlled by careful management and use of settling ponds.
Dissolved-solids concentrations also are much larger naturally in ephemeral streams than in perennial streams. Soluble salts and minerals tend to accumulate in soils of these semiarid areas, because precipitation and runoff are insufficient to provide adequate leaching. An additional source of soluble mineral salts and trace elements is unweathered rock material exposed by mining. Runoff from these areas may have larger concentrations of dissolved solids and dissolved or totalrecoverable trace elements.

One of the most common water-quality problems in the Eastern United States is acid mine drainage; however, this problem is largely unknown in western coal mines. Iron sulfides (pyrite and marcasite) commonly occur in coals and associated strata. Once exposed to the atmosphere by mining, these minerals are readily oxidized, producing sulfuric acid and ironhydroxide precipitate. Increased acidity in the water, in turn, results in increased dissolution of additional minerals. Such water draining a mined area generally has $\mathrm{pH}$ values ranging from 2.5 to 5.0 , and large sulfate, trace-element, and dissolved-solids concentrations.

In the study area of this report, the chemicalweathering reaction is the same, but the native waters are buffered by carbonate and bicarbonate (alkalinity), normally preventing the development of acid waters and large concentrations of dissolved trace elements. The semiarid climate also aids in preventing the formation of acid water. Overall, some increases in dissolved solids, particularly sulfate, and increases in total-recoverable trace-element concentrations are likely as a result of mining. But, because the $\mathrm{pH}$ of the water is neutral-tobasic, and because bicarbonate is abundant, trace elements largely remain in the suspended phase, sorbed to the fine-grained sediment. Increases in totalrecoverable trace-element concentrations, then, are usually associated with increases in suspended-sediment concentration. 


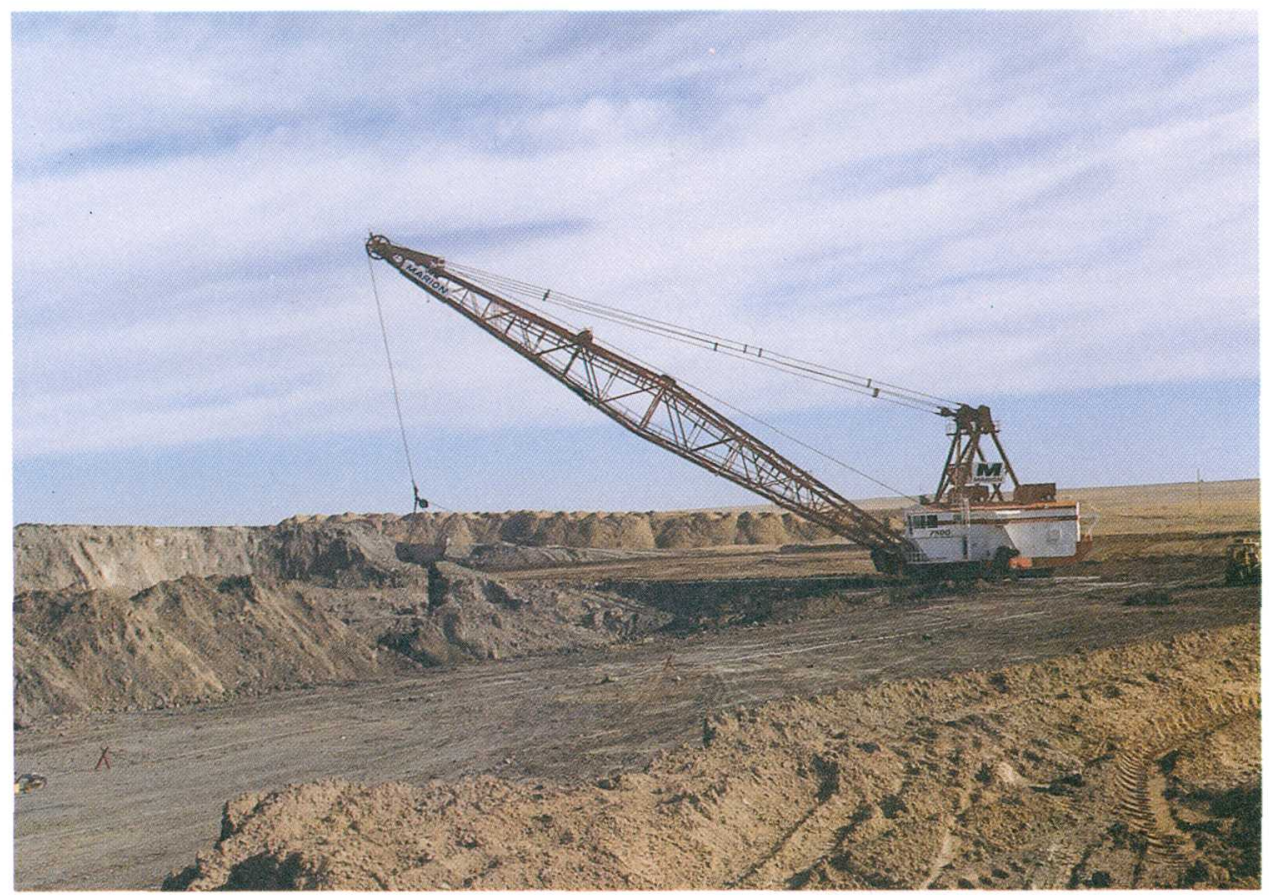

Figure 1.3.1-1 Spoil piles at a surface coal mine.

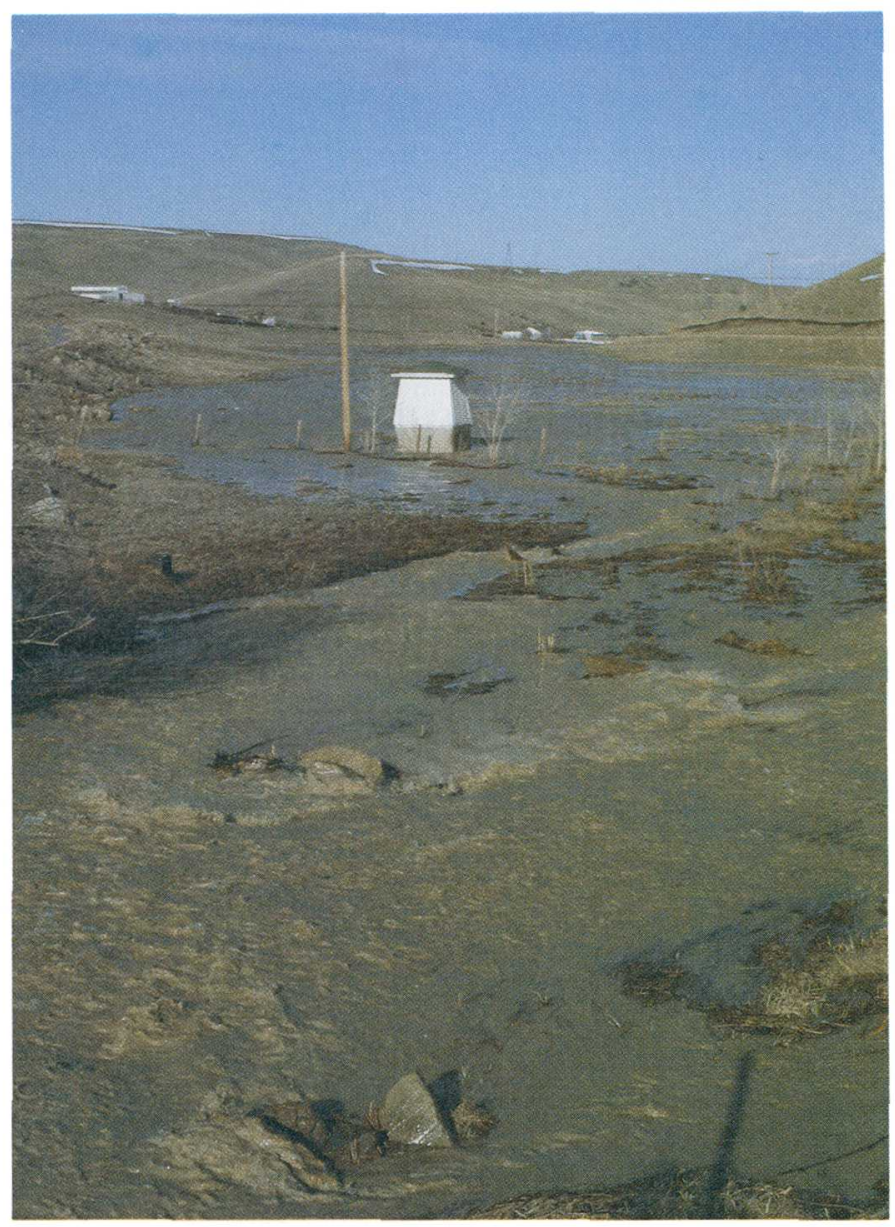

Figure 1.3.1-2 Leyden Gulch, northwest of Denver, Colorado. Sediment-laden spring runoff overflows the main channel.

\subsection{INTRODUCTION--Continued}




\author{
1.0 INTRODUCTION--Continued \\ 1.3 Hydrologic Problems Related to Surface Mining--Continued \\ 1.3.2 Impacts on Ground Water
}

\title{
Quantity and Quality of Ground Water Can Be Affected By Surface Mining
}

\author{
Degradation of ground-water quality and decline in water levels \\ are typical problems associated with surface coal mining.
}

Effects of mining on ground water probably will be much more severe and of a longer duration than effects on surface waters. However, in parts of the coal areas, ground-water and surface-water systems may be connected. Effects on ground water, such as degradation of quality, then may be reflected in the surface water of the area, resulting in poorer quality streamflow.

Aquifers in the coal areas can occur in alluvium, overburden, coal seams, and beds underlying coal seams. One of the major impacts of mining is the total or partial loss of an aquifer by removal of overburden or coal. After reclamation, these aquifers may or may not be reestablished in the spoil material. Dewatering of aquifers adjacent to mines (fig. 1.3.2-1) results in a decline in water levels for some distance from those aquifers, and adjacent water-supply wells could be affected. After mining and reclamation, ground-water levels may rise with time in undisturbed areas near the mined areas. This rise may result from increased recharge in the reclaimed mine areas.

Disruption of aquifers and related effects from surface mining also will affect ground-water quality. The rock material exposed and fragmented by mining is largely unweathered. As water moves through the spoils, it will probably increase in dissolved solids and trace elements. The water usually is in contact with the spoils for a long time, and dissolved solids may increase significantly in aquifers in mine spoils. Also, prior to mining, two or more aquifers with very different water- quality characteristics may be separated by relatively impermeable layers. Disruption by mining could effectively join these aquifers, resulting in degradation or improvement of water quality in some aquifers.

Effects of mining on the aquifers of Area 59 have not been studied; however, studies in other areas show that increases in dissolved-solids concentrations may be noted in waters in mine-spoil aquifers (Van Voast, 1974; Van Voast and others, 1977; and McWhorter and others, 1977). In their study of the effects of mining on the hydrology of a small watershed in northwestern Colorado, McWhorter and others $(1977$, p. 5) concluded that "dissolved-solids concentration in overland flow runoff is very small compared to that in subsurface runoff," and the "concentration of dissolved solids in subsurface drainage from a bank of mine spoils cannot be expected to decline for many decades." Van Voast and others (1977, p. 42) suggest that water from mine spoils in southeastern Montana may have dissolved-solids concentrations ranging between 1,000 and 5,000 milligrams per liter. Dissolved-solids concentrations ranging from 328 to 8,160 milligrams per liter have been noted in groundwater samples from the Wyoming coal area (Freuden. thal, 1979); however, none of these samples were from mine spoils. It is not certain if any of the larger concentrations observed here are due to mining, or whether dissolved-solids concentrations in mine-spoil aquifers of the report area will be similar or different from those observed in undisturbed aquifers. 

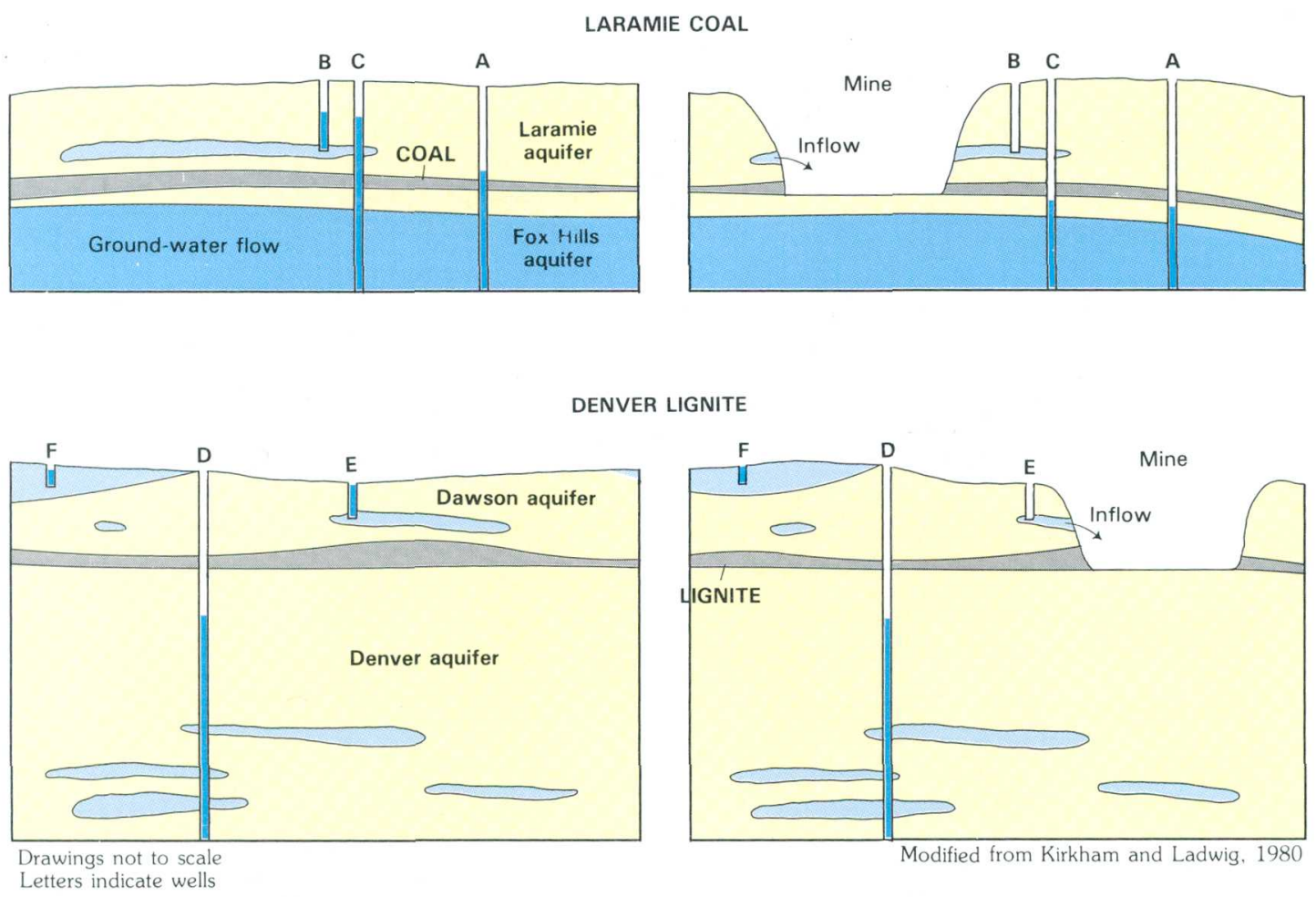

Figuare 1.3.2-1 Hypothetical examples showing how water wells may be affected by surface mining Laramie coal (upper diagram) and Denver lignite (lower diagram).

\subsection{INTRODUCTION--Continued}

1.3 Hydrologic Problems Related to Surface Mining 1.3. 2 Impacts on Ground Water 


\title{
2.0 DEFINITION OF TERMS
}

\section{Terms Used in Hydrologic Reports Defined}

\author{
Technical terms that are used in this hydrologic report are defined.
}

Algae are mostly aquatic, single-celled, colonial, or multicelled plants containing chlorophyll and lacking roots, stems, and leaves.

Anion is a negatively charged ion.

Anticline is a fold that is convex upward, with the older rocks toward the center of curvature.

Aquifer is a geologic formation, group of formations, or part of a formation that contains sufficient saturated permeable material to yield significant quantities of water to wells and springs.

Alluvial aquifer is an aquifer located in unconsolidated stream deposits of comparatively recent time.

Base flow (or base runoff) is sustained or fairweather runoff composed largely of ground-water discharge.

Benthic invertebrate, for this study, is an animal without a backbone, living within or near the bottom of an aquatic environment and which is retained on a 210 -micrometer mesh sieve.

Cation is a positively charged ion.

Cells per volume refers to the number of cells of any organism which is counted by using a microscope and grid or counting cell. Many planktonic organisms are multicelled and are counted according to the number of contained cells per sample volume, usually milliliters $(\mathrm{ml})$ or liter (L).

Climate year in the U.S. Geological Survey is the 12-month period, April 1 through March 31. The climate year is designated by the calendar year in which it ends and which includes 3 of the 12 months. Thus, the year ending March 31, 1981, is called the "1981 climate year."
Coefficient of determination $\left(r^{2}\right)$, in linear regression, is the square of the correlation coefficient. The coefficient of determination $\times 100$ provides a measure of the percentage of the variation of the dependent variable explained by variation of the independent variable.

Conglomerate is a rock consisting of rounded, waterworn fragments of other rock or pebbles cemented together by another mineral.

Cubic foot per second $\left(\mathrm{ft}^{3} / \mathrm{s}\right)$ is the rate of discharge representing a volume of 1 cubic foot passing a given point during 1 second and is equivalent to approximately 7.48 gallons per second, or 448.8 gallons per minute, or 0.02832 cubic meters per second.

Dewatering, in this report, refers to the artificial discharge of water from an aquifer because the aquifer is exposed in a mine pit. Removal of such water from the mine pit also may be termed dewatering.

Discharge is the volume of water (or more correctly, volume of water plus suspended sediment) that passes a given point within a given period of time.

Average discharge is the arithmetic average of individual discharges during a specific period of time. Instantaneous discharge is the discharge at a particular instant in time.

Dissolved refers to that material in a representative water sample which passes through a 0.45 -micrometer membrane filter. This may include some very small (colloidal) suspended particles as well as the amount of substance present in true chemical solution. Determinations of "dissolved" constituents are made on subsamples of the filtrate. 
Dissolved oxygen (DO) is the dissolved-oxygen content of water in equilibrium with air and is a function of atmospheric pressure and temperature and dissolved-solids concentration of the water. The capacity of water for dissolved oxygen decreases as dissolved solids or temperature increase or as atmospheric pressure decreases.

Drainage area of a stream at a specific location is that area, measured in a horizontal plane, enclosed by a topographic divide from which direct surface runoff from precipitation normally drains by gravity into the stream above the specified point. Figures of drainage area given herein include all closed basins, or noncontributing areas, within the area unless otherwise noted.

Drainage basin is a part of the surface of the Earth that is occupied by a drainage system, which consists of a surface stream or a body of impounded surface water together with all tributary surface streams and bodies of impounded surface water.

Ephemeral stream is one which flows only in direct response to precipitation and whose channel is at all times above the water table.

Evapotranspiration is the water 'withdrawn from a land area by evaporation from water surfaces and moist soil and by plant transpiration; it is the loss of water from leaf and stem tissues of growing vegetation.

Gaging station is a particular site on a stream, canal, lake, or reservoir where systematic observations of hydrologic data are obtained. When used in connection with a discharge record, the term is applied only to those gaging stations where a continuous record of discharge is computed.

Hydrograph is a graph showing discharge, water level, or other property of water with respect to time.

Hydrologic unit is a geographic area representing part or all of a surface drainage basin or distinct hydrologic feature as delineated by the Office of Water Data Coordination on the State Hydrologic Unit Maps; each hydrologic unit is identified by an eight-digit number.
Igneous rock is a rock formed by solidification from molten or partially molten materials.

Ion is an atom, group of atoms, or molecule that has acquired a net electrical charge.

Lithology is the physical character of a rock, generally determined by observation with the unaided eye or with the aid of a low-power magnifier.

Load is the amount of material, whether dissolved, suspended, or on the bed, that is moved and transported by a flowing stream.

Metamorphic rock is a rock which has been altered in composition, texture, or internal structure in response to pronounced changes of temperature, pressure, and chemical environment.

Micrograms per liter $(\mu \mathrm{g} / \mathrm{L})$ is a unit expressing the concentration of chemical constituents in solution as mass (micrograms) of solute per unit volume (liter) of solution. One thousand micrograms per liter is equivalent to one milligram per liter.

Milligrams per liter $(\mathrm{mg} / \mathrm{L})$ is a unit for expressing the concentration of chemical constituents in solution. Milligrams per liter represent the mass of solute per unit volume (liter) of water. Concentration of suspended sediment also is expressed in $\mathrm{mg} / \mathrm{L}$, and is based on the mass of sediment per liter of water-sediment mixture.

Moles per liter is a unit expressing the concentration of chemical constituents in solution. A mole is a mass, expressed in grams, equivalent to the molecular weight.

Orogeny is the process of mountain formation.

Oxidation is the removal of one or more electrons from an element or ion, thus increasing its positive charge or decreasing its negative charge.

Partial-record station is a particular site where limited streamflow or water-quality data are collected systematically over a period of years for use in hydrologic analyses. 
Perennial stream is one that flows continuously.

Plankton are any organisms, usually minute in size, floating, or drifting in water.

$p H$ is a measure of the hydrogen ion activity. Values on the $\mathrm{pH}$ scale range from 0 to 14 , and denote whether a solution is acidic or basic (alkaline). A pH of 7.0 refers to a neutral solution. Solutions with $\mathrm{pH}$ ranging from 0 to less than 7.0 are considered acidic; solutions with $\mathrm{pH}$ ranging greater than 7.0 are denoted as basic.

Phytoplankton is the plant part of the plankton. They are usually microscopic, and their movement is subject to the water currents. Phytoplankton growth is dependent upon solar radiation and nutrient substances. Because they are able to incorporate as well as release materials to the surrounding water, the phytoplankton have a profound effect upon the quality of the water. They are the primary food producers in the aquatic environment, and are commonly known as algae.

Blue-green algae are groups of phytoplankton organisms having blue pigment, in addition to the green pigment called chlorophyll. Blue-green algae often cause nuisance conditions in water.

Diatoms are the unicellular or colonial algae having a siliceous shell. Their concentrations are expressed as number of cells per milliliter of sample.

Zooplankton is the animal part of the plankton. Some zooplankton are capable of extensive movements within the water column, and are often large enough to be seen with the unaided eye. Zooplankton are secondary consumers feeding upon bacteria, phytoplankton, and detritus. Because they are the grazers in the aquatic environment, the zooplankton are a vital part of the aquatic food web.

Recharge is the process by which water is absorbed and added to the zone of saturation (an aquifer), either directly into a formation or indirectly by way of another formation. Recharge is also the quantity of water that is added to the zone of saturation.
Runoff is that part of the precipitation that appears in surface streams.

Sediment is solid material that originates mostly from disintegrated rocks and is transported by, suspended in, or deposited from water; it includes chemical and biochemical precipitates and decomposed organic material, such as humus. The quantity, characteristics, and cause of the occurrence of sediment in streams are influenced by environmental factors. Some major factors are degree of slope, length of slope, soil characteristics, land use, and quantity and intensity of precipitation.

Suspended sediment is the sediment that at any given time is maintained in suspension by the upward components of turbulent currents, or that exists in suspension as a colloid.

Specific conductance is a measure of the ability of water to conduct an electric current. Specific conductance is primarily from dissolved ions. The larger the dissolved-ion concentration in the water, the larger the specific-conductance value.

Suspended-sediment concentration is the velocity-weighted concentration of suspended sediment in the sampled zone (from the water surface to a point approximately 0.3 foot above the bed) expressed as milligrams of dry sediments per liter of water-sediment mixture $(\mathrm{mg} / \mathrm{L})$.

Sedimentary rock is a rock formed by the accumulation of sediment in water or from the air. The sediment may consist of rock fragments of various sizes, of the remains or products of animals and plants, of the product of chemical action or evaporation, or a mixture of these materials.

Solute is any substance derived from the atmosphere, vegetation, soil, or rocks and dissolved in water.

Specific conductance is a measure of the ability of a water to conduct an electrical current. It is expressed in micromhos per centimeter at $25^{\circ}$ Celsius. Specific conductance is related to the number and specific chemical types of ions in solution and can be used for approximating the dissolved-solids content in the water. Commonly, 
the concentration of dissolved solids (in milligrams per liter) is about 65 percent of the specific conductance (in micromhos). This relation is not constant from stream to stream or from well to well, and it may vary in the same source with changes in the composition of the water.

Streamflow is the discharge that occurs in a natural channel. Although the term "discharge" can be applied to the flow of a canal, the word "streamflow" uniquely describes the discharge in a surface stream course. The term "streamflow" is more general than "runoff" as streamflow may be applied to discharge whether or not it is affected by diversion or regulation.

Subbituminous coal is a coal of rank between lignite and bituminous.

Syncline is a fold that is convex downward, with the younger rocks toward the center of curvature.

Tectonic activity (tectonism) is any form of instability in or deformation of the Earth's crust.

Total recoverable is the amount of a given constituent that is in solution after a representative water-suspended sediment sample has been digested by a method (usually using a dilute acid solution) that results in dissolution of only readily soluble substances. Complete dissolution of all particulate matter is not achieved by the digestion treatment, and thus the determination represents something less than the "total" amount (that is, less than 95 percent) of the constituent present in the dissolved and suspended phases of the sample. To achieve comparability of analytical data, equivalent digestion procedures would be required of all laboratories performing such analyses because different digestion procedures are likely to produce different analytical results.

Trace element is any element of water which generally occurs in concentrations of less than 1 milligram per liter. However, some trace elements may at times exceed this concentration.

Water year in the U.S. Geological Survey is the 12-month period, October 1 through September 30. The water year is designated by the calendar year in which it ends and which includes 9 of the 12 months. Thus, the year ending September 30, 1981, is called the "1981 water year." 


\title{
3.0 GENERAL FEATURES \\ 3.1 Surface Drainage
}

\section{Area Entirely in South Platte River Basin}

\author{
Area 59 is drained by the South Platte River and six of its major tributaries, \\ that have their entire drainage basins within the area.
}

Located entirely within the South Platte River basin, Area 59 is drained by the South Platte River, six major tributaries, and numerous smaller tributaries (fig. 3.1-1). Most streams that originate in the mountains are perennial and maintain perennial flow as they flow from the mountains across the plains and into the South Platte River. Streams that originate in the plains, on the other hand, are primarily ephemeral or dry washes, and generally flow only in response to snowmelt or rainstorms. However, in some areas in the plains, ground-water discharge from alluvial aquifers has become a significant source of streamflow, because leaking irrigation canals have recharged nearby alluvial deposits (Boyd, 1897; Hurr and others, 1975, p. 17).

The South Platte River originates in the mountains surrounding South Park in the southwestern part of Area 59 (fig. 3.1-1). The river follows a southeasterly course through most of South Park, turning northeast to cut through the Rampart Range and across the Colorado Piedmont (fig. 3.1-1) to near Greeley, Colo. Up to this point, the South Platte River has numerous perennial tributaries originating in the mountains, including three major tributaries, which are St. Vrain Creek, the Big Thompson River, and Cache la Poudre River. Snowmelt in the Rocky Mountains is the primary source of streamflow for all streams originating in the mountains.

From Greeley, the South Platte River follows an easterly course and is joined by three other major tributaries, Bijou Creek and Kiowa Creek, flowing from the south, and Crow Creek, flowing generally from the north. These tributaries and other smaller ones downstream from Greeley are usually ephemeral, even though their drainage basins may be quite large. Drainage areas of the major tributaries are:

St. Vrain Creek..................... = 978 square miles

Big Thompson River.............. $=832$ square miles

Cache la Poudre River............ = 1,917 square miles

Bijou Creek............................ = 1,500 square miles

Kiowa Creek........................... = 703 square miles

Crow Creek............................ = 1,377 square miles

Large quantities of water are diverted from many of the perennial streams for irrigation in the highly developed agricultural areas [agriculture uses 90 to 95 percent of the water used in Colorado (Colorado LandUse Commission, 1974, Water Service Areas map)]. Additional diversions are made to reservoirs to store water, to supplement water diverted directly from the streams. Also, water from perennial streams in the mountains is diverted and stored in numerous reservoirs (see section 4.3), to provide water for domestic use for the large population centers along the Front Range.

The major tributaries of the South Platte River in the plains are Bijou Creek and Crow Creek. Bijou Creek flows from the south; Crow Creek flows from the north. The major tributaries and the many smaller ones in the plains generally have wide sandy channels, with little or no surface flow, except during rainstorms when flooding can occur. In agricultural regions, such as the eastern half of Area 59 and South Park in Park County, Colo., irrigation canals take water from perennial streams, such as the South Platte River, and divert it to storage reservoirs many miles from the point of diversion. 

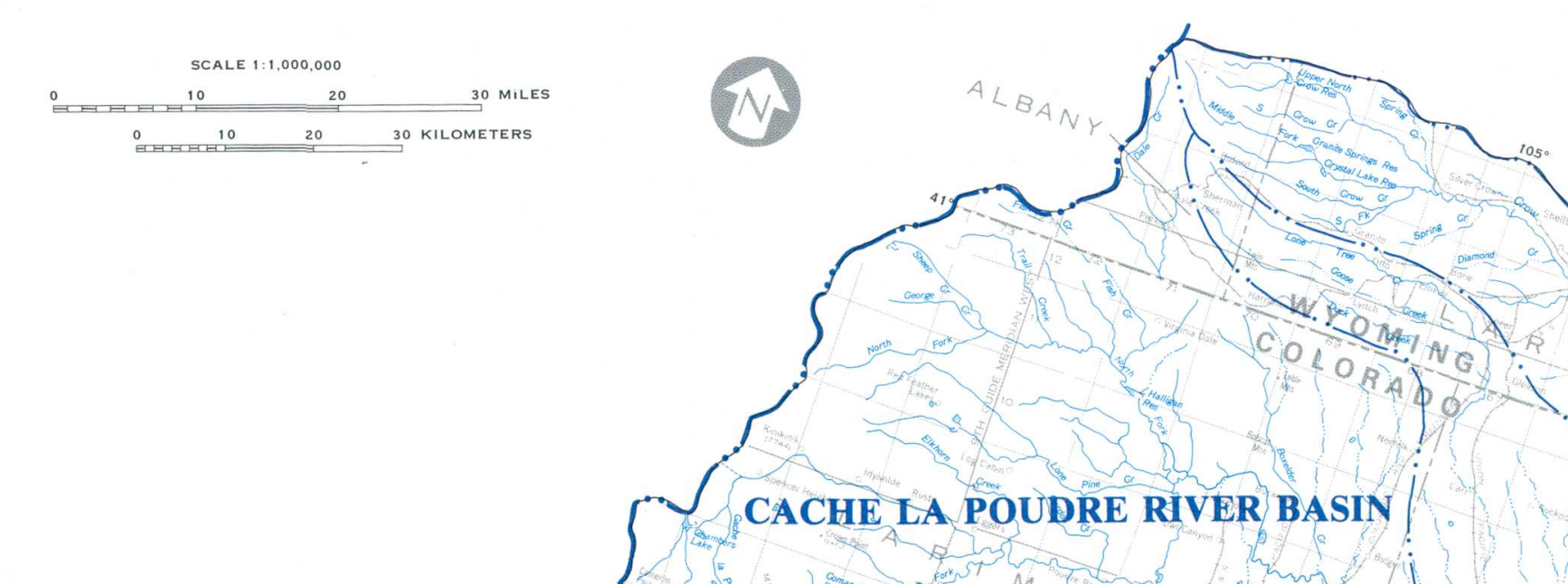

EXPLANATION


A dry streambed in the plains near the Colorado-Wyoming border.

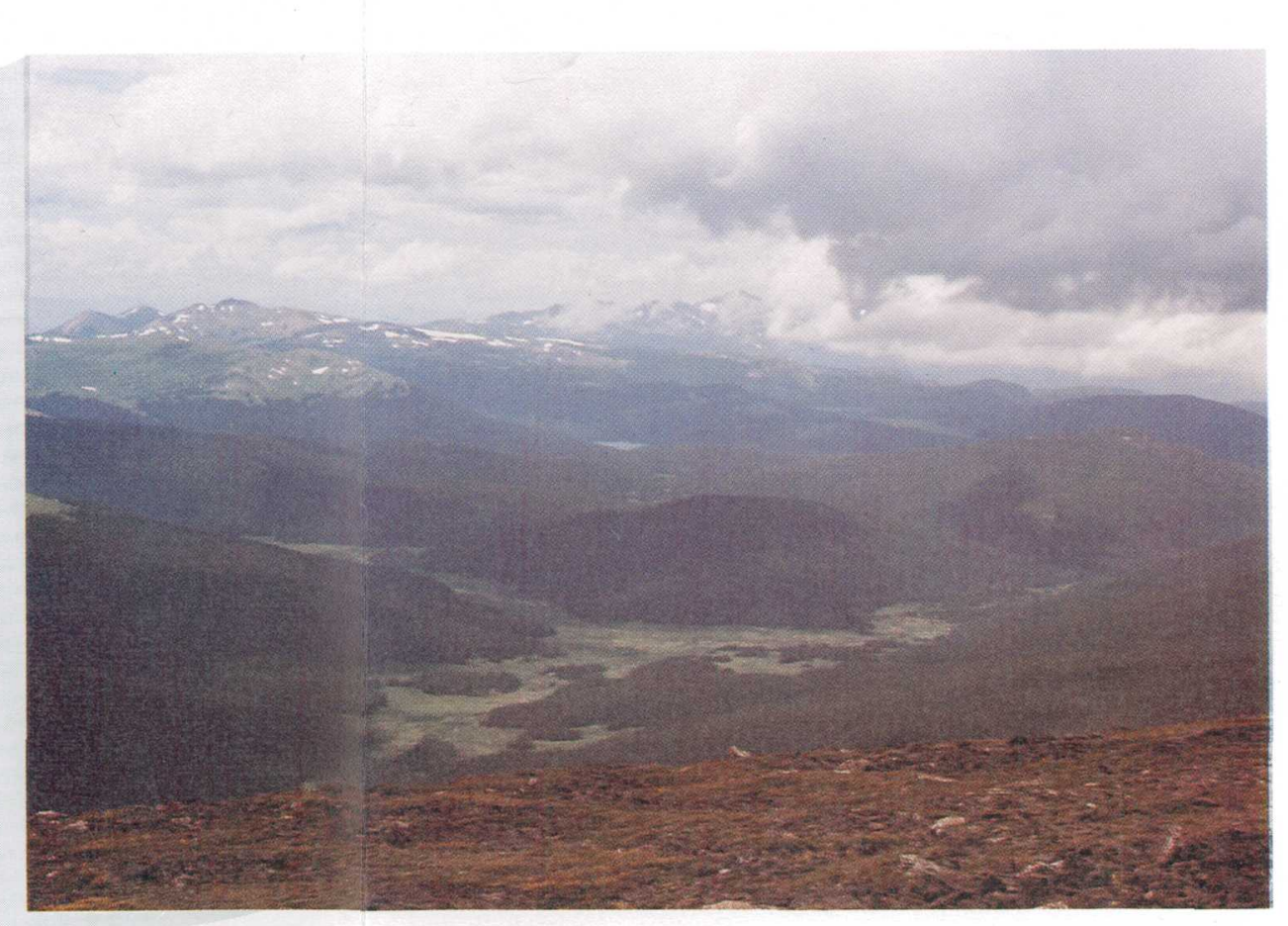

The headwaters of the Cache La Poudre River, looking northwest. 


\title{
3.0 GENERAL FEATURES--Continued \\ 3.2 Topography and Physiography
}

\section{Area 59 is in the Great Plains and Southern Rocky Mountains Physiographic Provinces}

\author{
The physiography changes from rolling plains \\ in the east to sharp mountain peaks in the west.
}

Area 59 is in both the Great Plains and the Southern Rocky Mountains physiographic provinces, as defined by Fenneman (1946) (fig. 3.2-1). The major topographic features in the area are the hogback ridges, buttes, mesas, and forested highlands of the Great Plains province, and the mountain ranges and parks (flat, mostly treeless areas surrounded by mountains) in the Southern Rocky Mountain province.

About two-thirds of the area is in the Great Plains province, which has two subdivisions, the Colorado Piedmont and the High Plains sections (fig. 3.2-1). The southern part of the Colorado Piedmont section of the Great Plains province in Area 59, near the Palmer Divide, is characterized by deeply dissected stream valleys and buttes, grading to low, rolling hills near the South Platte River. The northern part of this section of the Colorado Piedmont, south of the Colorado-Wyoming border, is characterized by almost treeless, rolling prairie with wide, sandy stream channels that trend to the south, toward the South Platte River. The few trees that exist here are mainly confined to the stream channels. The northern boundary of this section, just south of the Colorado-Wyoming border, is marked by bluffs and buttes several hundred feet high (fig. 3.2-1).

At the foot of the Front Range, the horizontal deposits of the Colorado Piedmont have been selectively eroded to form buttes and mesas with erosion-resistant formations on top, protecting less resistant beds underneath. Closer to the mountains, these once-horizontal formations have been deformed so that they are almost vertical. The most resistant of these formations form hogback ridges along the mountain front.

The Chalk Bluffs, which are as much as several hundred feet high, are found along the northern boundary of the Colorado Piedmont and mark the eroded edge of the High Plains section of the Great Plains physiographic province. About 5 million years ago deposits from the erosion of the ancient mountain systems formed the High Plains and covered most of the Great Plains, including the part in Area 59 (Trimble, 1980, p. 26). However, the South Platte River and its tributaries have eroded the ancient High Plains in Area 59, so that only a small area in Wyoming and Colorado remains (fig. 3.2-1). The part of the High Plains section west of Cheyenne, Wyo., also is referred to as "the Gangplank," since it is the only place where the old surface still extends all the way to the mountains (Trimble, 1980, p. 27). The topography of the High Plains ranges from flat to rolling.

Within Area 59, the Southern Rocky Mountain physiographic province consists of the Front Range, the Laramie Mountains, and South Park (Park County, Colo.). The Front Range makes up nearly all of the Rocky Mountains in the area; it is a composite of several mountain ranges, that have been cut by streams forming $v$ shaped valleys, and glaciers forming $u$-shaped valleys. Altitudes range from less than 5,000 feet at the eastern boundary of the Front Range to more than 14,000 feet at several mountain peaks on the Continental Divide. A zone of so-called "foothills" lie along the boundary of the Front Range just east of the Great Plains. Altitudes in the foothills range from about 5,500 feet to about 8,000 feet.

The Laramie Mountains form the northern end of the Front Range, extending from about the Cache la Poudre River northward into Wyoming. Altitudes in the Laramie Mountains are generally less than 10,000 feet.

South Park (fig. 3.2-1), which covers a large part of Park County, Colo., is the largest park in Area 59. South Park consists of gently rolling, mostly treeless terrain, surrounded by mountains. The eastern and northern borders are formed by ranges of the Front Range; the Mosquito Range borders the park on the west. Volcanic peaks form most of the southern border.

One of the most prominent features in the Rocky Mountains is the Continental Divide, which forms part of the western boundary of Area 59. A photograph in (fig. 3.2-1) shows the Indian Peaks, which are part of the Continental Divide northwest of Boulder, Colo. The divide forms the drainage divide between the Colorado River basin, west of Area 59, and the Mississippi River basin, of which the South Platte River is a part. 

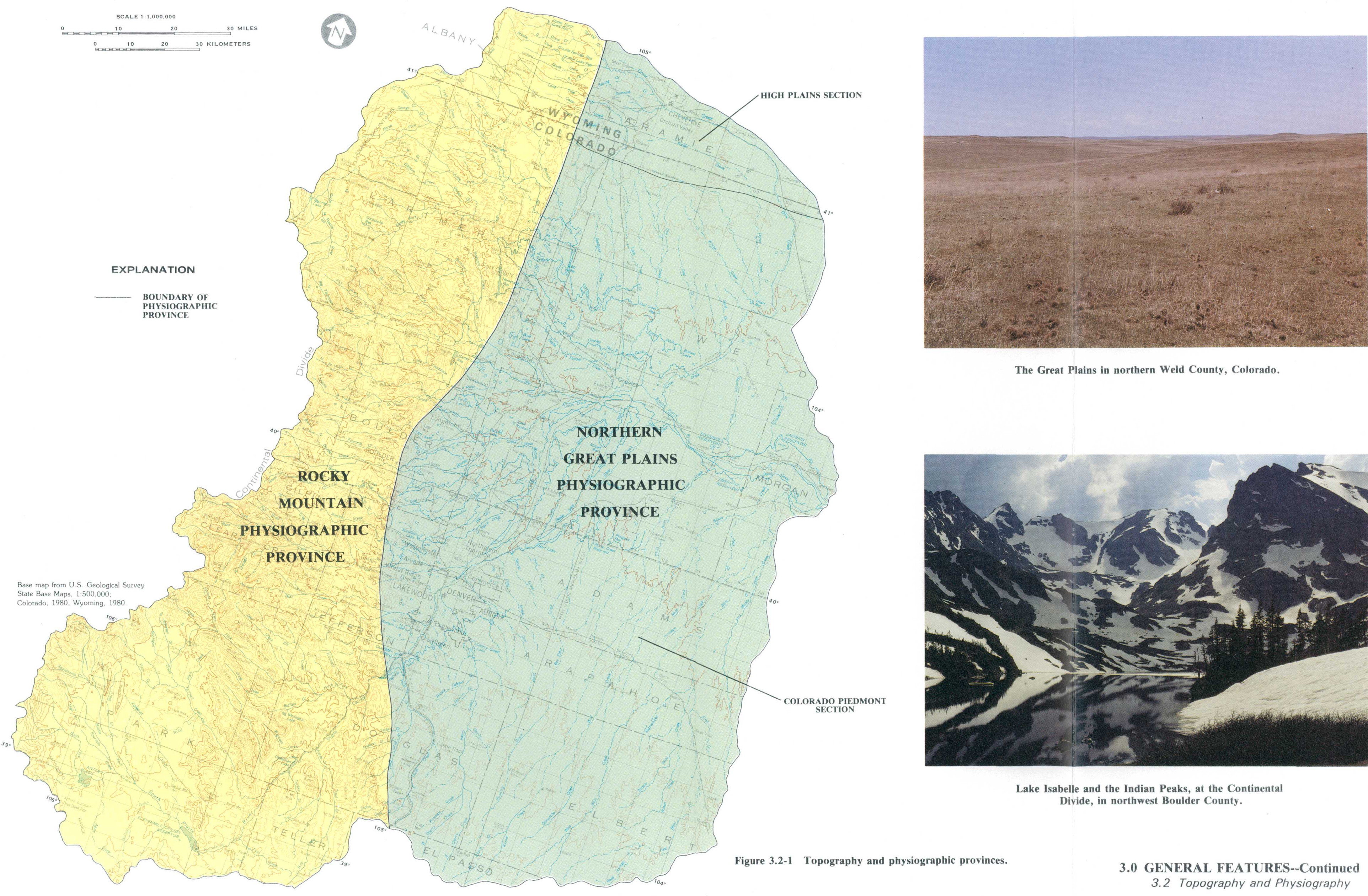

The Great Plains in northern Weld County, Colorado.

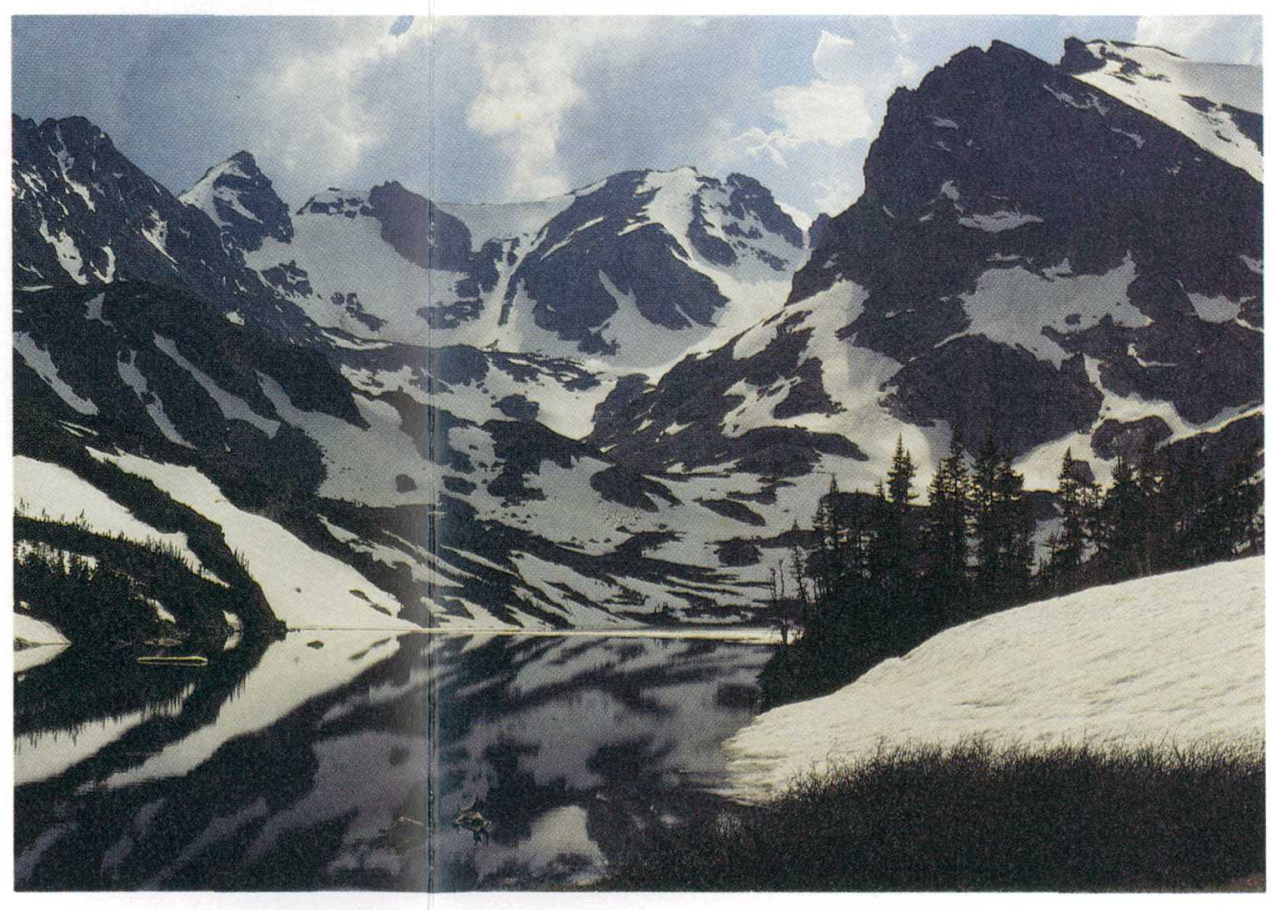

Lake Isabelle and the Indian Peaks, at the Continental . 


\title{
3.0 GENERAL FEATURES--Continued 3.3 Soils
}

\section{The Soils in the Plains are More Alkaline Than Those in the Mountains}

\author{
The most common soils in the mountains are light colored, medium acid to \\ neutral, and well drained. Soils in the plains are generally dark colored, \\ neutral to moderately alkaline, and well drained.
}

Nine general soil associations are shown in figure 3.3-1; they are described in detail in table 3.3-1. Three soil associations are found in the mountains; six soil associations are found in the plains. Descriptions of the soil associations, depth to bedrock, $\mathrm{pH}$, and permeability are listed for each soil association. Depth to bedrock is the depth from the soil surface to consolidated rock. The degree of soil acidity or alkalinity is expressed by $\mathrm{pH}$. Finally, permeability, the ability of air or water to pass through soil, is expressed as the number of inches of water able to pass through the soil per hour.

Three general soil associations found in the mountains are: (1) Cryumbrepts-Cyochrecpts-rock outcrop soils (No. 1 in table 3.3-1), which are dark-colored, well-drained soils found at the highest altitudes in the area and form on alpine slopes and meadows from Crystalline rocks; (2) Cryoboalfs-rock outcrop soils (No. 2 in table 3.3-1) which are the most extensive in the area and are made up of light-colored soils on timbered mountain slopes formed from both crystalline and sedimentary rocks; and (3) Cryaquolls-Argiborolls-Hapliborolls-Cryoborolls-rock outcrop soils (No. 3 in table 3.3-1), which are dark-colored and well to poorly drained, are found on foothills and mountains and are formed from a variety of residual materials (Heil and others, 1977; Young and Singleton, 1977).

High-altitude soil association No. 1 has: (1) Depth to bedrock ranging from less than 20 to more than 40 inches; (2) $\mathrm{pH}$ ranging from strongly acid to medium acid (4.5 to 6.0) (Young and Singleton, 1977 , p. 38); and (3) permeability ranging from moderate to moderately rapid ( 0.6 to 6.0 inches per hour). Soil asssociation No. 2 has: (1) Depth to bedrock ranging from 20 to more than 60 inches; (2) $\mathrm{pH}$ ranging from medium acid to neutral (5.6 to 7.3); and (3) moderate permeability ranging from 0.6 to 2.0 inches per hour. Soil association No. 3 has: (1) Depth to bedrock ranging from less than 20 to more than 60 inches; (2) $\mathrm{pH}$ ranging from slightly acid to moderately alkaline $(6.1$ to 8.4); and (3) permeability ranging from moderately slow to rapid ( 0.2 to 20 inches per hour).

Six general soil associations are dispersed throughout the plains (fig. 3.3-1 and table 3.3-1). The most extensive soil association is the Argiustolls-Haplargids-HaplustollsPaleustolls-Torriorthents-Paleargids (No. 4 in table 3.3-1), which is made up of mostly dark soils that have been formed by material weathered in place, and by wind-deposited material on uplands and alluvial fans. The Haplargids-TorriorthentsCamborthids soil association (No. 5 in table 3.3-1) is the most dispersed in the area. It is made up of light-colored, well to moderately drained soils formed on nearly level to steep uplands.
The Torriorthents (No. 6 in table 3.3-1) and TorripsammentsHaplargids (No. 7 in table 3.3-1) are both formed from sandy and alluvial material; however, No. 6 soils were weathered in place or locally transported, and No. 7 soils were wind-deposited. The small area in the southern tip of the plains is overlain by the Eutroboralfs-Haploborolls soils (No. 8 in table 3.3-1), which are formed from materials weathered in place or locally transported from arkose beds. This small area also is part of a region of wooded highlands at altitudes above 6,000 feet, locally referred to as the Black Forest (fig. 3.3-1). The Black Forest also has mountain soil association No. 3 , since the altitudes and climate are similar to those where No. 3 soils are found in the mountains. Finally, the Argiustolls-HaplustollsTorriorthents (No. 9 in table 3.3-1), located on the Wyoming High Plains, are light-and dark-colored, well drained to somewhat poorly drained soils, formed on upland plains, terraces, and alluvial fans.

Data on the soils on the plains (table 3.3-1) indicate that all these soil associations have maximum depth to bedrock of more than 60 inches; soil associations No. 4,5, and 8 have the smallest minimum depth to bedrock less than 20 inches. Only sandy-soil association No. 7 has a thickness of more than 60 inches to bedrock throughout its entire area. The $\mathrm{pH}$ of soils on the plains ranges from 5.1 to 8.4. Most of the soils are in the neutral to moderately alkaline range. Only soil association No. 8 , in the Black Forest region, is acid. Permeability of soils in the plains ranges from slow ( 0.06 inches per hour), in some soils of soil associations No. 4 , and 5 , to rapid ( 20 inches per hour) in some soils of soil asssociatons No. 5, 7, 8 and 9.

The difference in erosion characteristics between crystalline rocks in the west and softer sedimentary rocks in the east is graphically illustrated in figure 3.3-1. Wind and water have broken down, transported, and reworked the rocks in the plains into a variety of soil types; many more subdivisions are present than are shown here. Whereas, in the mountains, the variety of soil types is less; the pattern is more regular; and the soils seem to vary with altitude.

More detailed county soil maps are available for most of the counties in Area 59. For information on the status of soil surveys, contact the State Conservationist, U.S. Department of Agriculture, Soil Conservation Service, P.O. Box 17107, Denver, CO 80217, for Colorado, or the State Conservationist, U.S. Department of Agriculture, Soil Conservation Service, P. O. Box 2440, Casper, WY 82602 , for Wyoming. For more detailed information on the soil classification system see listings under "Soils" in the "Selected References" section (section 13.2). 


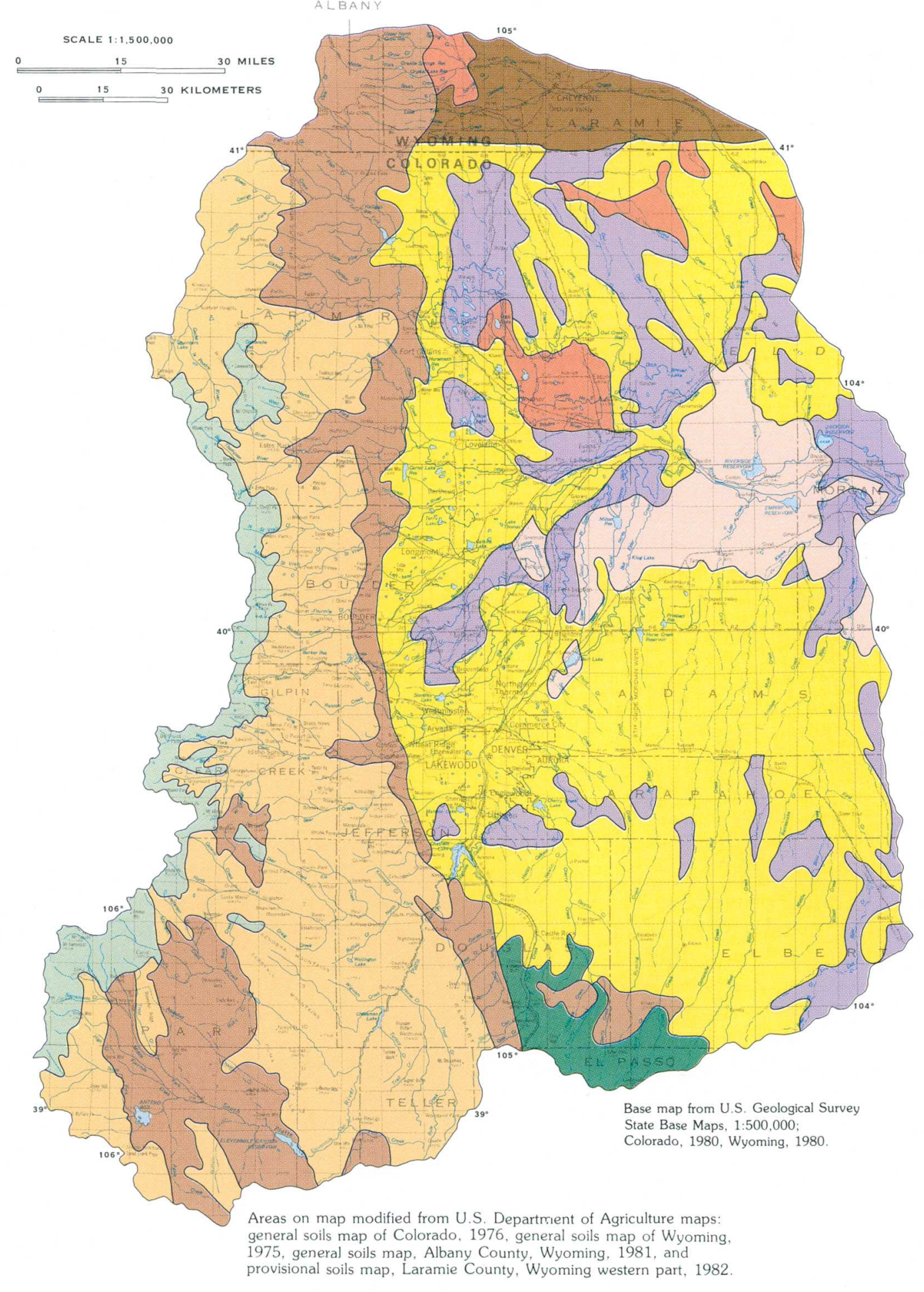

Table 3.3-1 Soil-association features.

\begin{tabular}{|c|c|c|c|c|}
\hline NAME & DESCRIPTION & $\begin{array}{c}\text { DEPTH TO BEDROCK } \\
\text { (inches) }\end{array}$ & $\mathrm{pH}$ & $\begin{array}{l}\text { PERMEABILITY } \\
\text { (inches per hour) } \\
\end{array}$ \\
\hline MOUNTAINS & & & & \\
\hline Cryumbrepts-Cryochrecpts (rock outcrop) & Dark-colored, well-drained soils on alpine slopes and meadows & $<20->40$ & $4.5-6.0$ & $0.6-6.0$ \\
\hline Cryoboralfs (rock outcrop) & $\begin{array}{l}\text { Light-colored, well-drained soils on timbered slopes, mesas and } \\
\text { sparsely vegetated escarpments }\end{array}$ & $20->60$ & $5.6-7.3$ & ${ }^{1} 0.6-2.0$ \\
\hline $\begin{array}{l}\text { Cryaquolls-Agriborolls-Hapliborolls-Cryoborolls } \\
\text { (rock outcrop) }\end{array}$ & $\begin{array}{l}\text { Dark-colored, well to poorly drained soils on steep mountain to } \\
\text { alluvial fans }\end{array}$ & $<20->60$ & $6.1-8.4$ & $0.2-20$ \\
\hline PLAINS & & & & \\
\hline $\begin{array}{l}\text { Argiustolls-Haplargids-Haplustolls-Paleu stolls- } \\
\text { Torriorthents-Paleargids }\end{array}$ & Dark-colored, well-drained soils on uplands and alluvial fans & $<20->60$ & $6.6-8.4$ & $0.06-6.0$ \\
\hline Haplargids-Torriorthents-Camborthids & $\begin{array}{l}\text { Light-colored, well to moderately drained soils on nearly } \\
\text { level to steep uplands }\end{array}$ & $<20->60$ & $6.6-8.4$ & $0.06-20$ \\
\hline Torriorthents & $\begin{array}{l}\text { Light-colored, well drained soils on nearly level to gently } \\
\text { sloping uplands and fans }\end{array}$ & $<20->60$ & 7.4-8.4 & $0.6-6.0$ \\
\hline Torripsaments-Haplargids & Light-colored excessively drained sandy soils having dune-like relief & $>60$ & $6.6-8.4$ & $2.0-20$ \\
\hline Eutroboralfs-Haploborolls & Light and dark-colored, well drained soils on forested highland & $<20->60$ & $5.1-7.3$ & $2.0-20$ \\
\hline Argiustolls-Haplustolls-Torriorthents & $\begin{array}{l}\text { Light and dark-colored, well-drained to somewhat poorly drained } \\
\text { soils on nearly level to tolling uplands plains, terraces, and fans }\end{array}$ & $<10->60$ & 2_- & $0.6-20$ \\
\hline
\end{tabular}

Figure 3.3-1 Location of soil associations 


\title{
3.0 GENERAL FEATURES--Continued \\ 3.4 Geology \\ 3.4.1 Bedrock Geology
}

\section{Bedrock from Precambrian to Tertiary Age is Represented in Area 59}

\author{
Rocks ranging in age from Precambrian in the western part of the area to \\ Miocene in Wyoming represent almost the entire geologic time scale.
}

Most of the bedrock in Area 59 is sedimentary rock of Cretaceous age or younger. Bedrock in the plains generally was formed from material that was eroded from the ancestral and present-day Rocky Mountains. The remainder of the bedrock, located in the mountains, consists of crystalline Precambrian rock and a few small areas of more recent volcanic extrusive and intrusive rock (fig. 3.4.1-1 and 3.4.1-2).

The sedimentary bedrock is found in the Denver-Julesburg basin, also referred to as the Denver-Cheyenne basin (Kirkham and Ladwig, 1980 , p. 10), and in South Park, a high plain surrounded by mountains. The Denver-Julesburg basin is a deep structural basin formed by Precambrian basement rock and extends north into Wyoming and south beyond the Area 59 boundary. The axis of the basin extends north and south near the border of the Front Range. The deepest parts of the basin are near Denver, Colo., and Cheyenne, Wyo. In South Park (Park County, Colo.), sedimentary bedrock formed on two downthrown, Precambrian fault blocks extends north and south between high mountain ranges (Washburne, 1908).

The sedimentary bedrock units cropping out in the Denver-Julesburg basin are: The Pierre Shale, the Fox Hills Sandstone, and the Laramie Formation, of the Mesozoic Erathem; the Arapahoe Formation, the Denver Formation and the Dawson Arkose of the Cenozoic and Mesozoic Erathems; and the White River Formation and the Ogallala Formation of the Cenozoic Erathem (fig. 3.4.1-2). The Laramie and Denver Formations contain the coal and lignite deposits in the area.

Most of the sedimentary deposits in South Park are of Paleozoic and Mesozoic age with some deposits of Cenozoic age. The Laramie Formation contains the only coal deposits in South Park (Washburne, 1908).

Bedrock throughout the Front Range is Precambrian crystalline rock. This region has had three major mountain building episodes since the Precambrian (Kirkham and Ladwig, 1980). Each episode was followed by extensive erosion which supplied the sediment for the deposits in the Denver basin and South Park.

For more information see the section on "Selected References" (section 13.2), which lists detailed studies of many parts of Area 59. Some of these studies were made as early as the mid-1800's. 


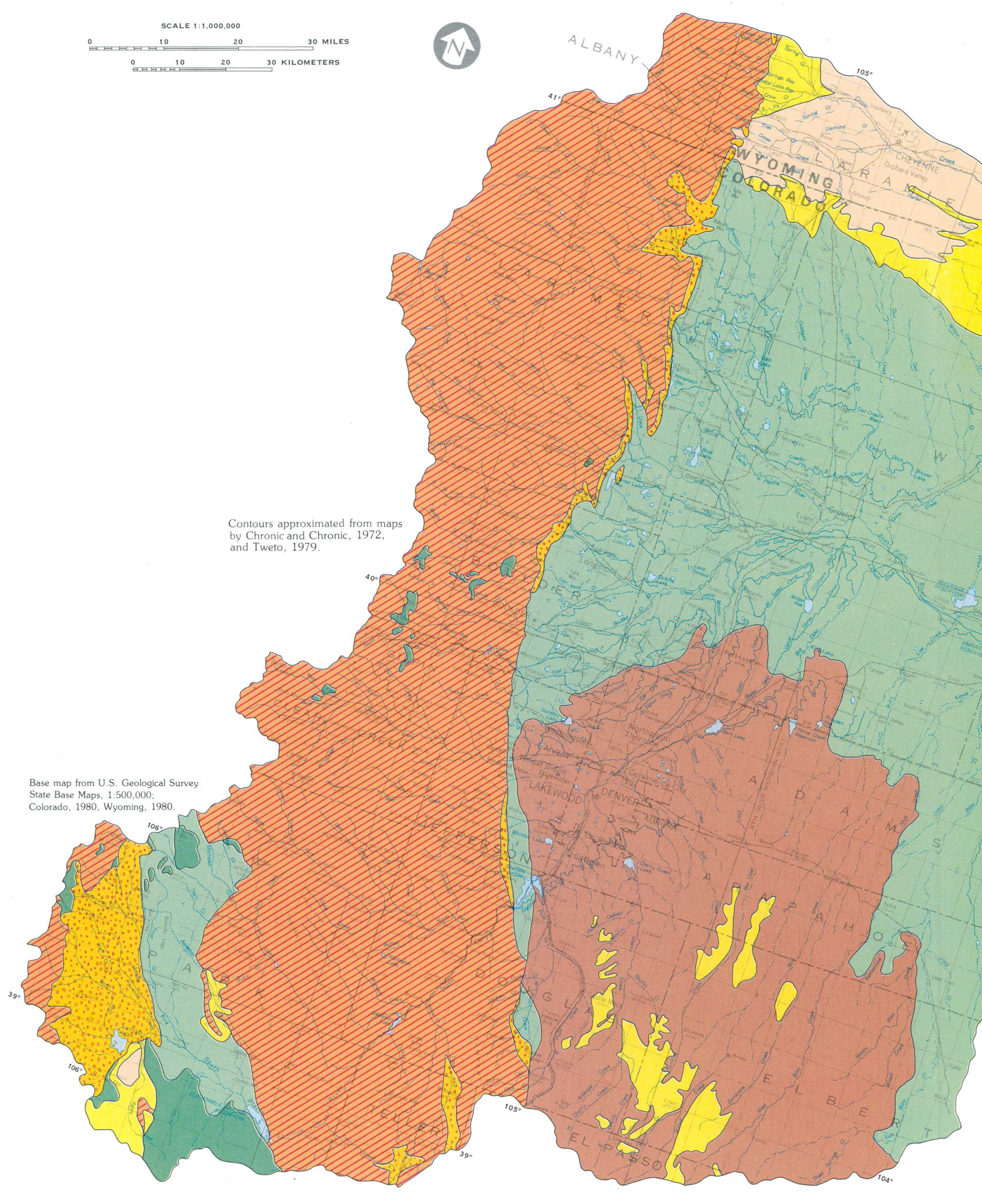

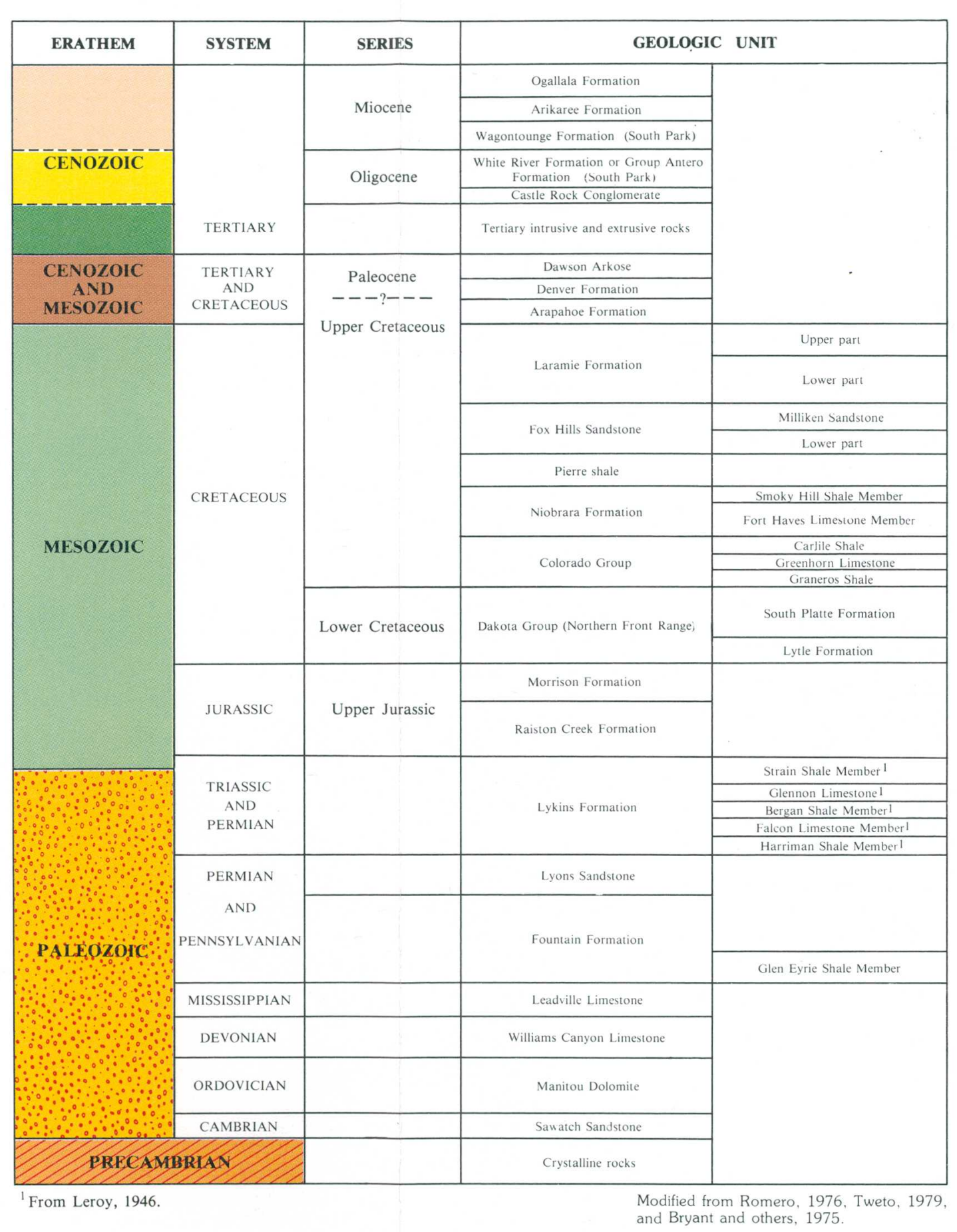

Figure 3.4.1-2 General composite section of bedrock units underlying Area 59. 


\title{
3.0 GENERAL FEATURES--Continued \\ 3.4 Geology--Continued \\ 3.4.2 Coal and Lignite Deposits
}

\section{Mineable Amounts of Coal and Lignite are Found in the Laramie and Denver Formations}

\author{
Coal areas are suitable for both surface and underground mining; \\ whereas, lignite areas are suitable only for surface mining.
}

Bituminous and subbituminous coal and lignite are found in Area 59 in both the Laramie Formation of Late Cretaceous age and the Denver Formation of Late Cretaceous and early Tertiary age. Coal and lignite beds in the Laramie Formation are generally less than 5 feet thick. Lignite beds in the Denver Formation range from 10 to 30 feet thick but are interbedded with layers of clay, sandstone, and shale (Kirkham and Ladwig, 1980). Areas where the Laramie and Denver Formations contain coal and lignite beds suitable for surface mining are shown in figure 3.4.2-1. In these areas the beds are less than 200 feet from the surface. This figure also indicates areas where coal beds of the Laramie Formation might be suitable for underground mining or underground gasification. Denver lignite is not suitable for underground mining, because tunnels dug into it would collapse too easily (Kirkham and Ladwig, 1980).

The Laramie Formation is shown in cross section in figures 3.4.2-2 and 3.4.2-3. Coal and lignite generally occur within the lower 50 to 275 feet of the Laramie Formation in the southern part of the basin (the area south of the South Platte River); but, their occurrence is not as predictable in the northern part of the basin. Coal and lignite beds in the Laramie Formation in the northern part of the basin are restricted to the lower 200 to 300 feet of the formation. The stratigraphic section shown in figure 3.4.2-4 is an example of Laramie coal beds in the southern part of the basin. However, because these coal beds occur as lens-shaped deposits and vary considerably in thickness throughout the formation, the thickness of the lower Laramie coal zone is quite variable within both parts of the basins. Approximately 7,500 square miles are underlain by the Laramie coal zone; however, only about 75 to 85 percent (approximately 5,600 square miles) are underlain by Laramie coal and lignite beds, because some of the coal and lignite are very thin or nonexistent (Kirkham and Ladwig, 1980, p. 48).

The lignite zone in the Denver Formation occurs in the top 300 to 500 feet of the formation. The base of this zone lies about 800 to 1,500 feet above the top of the Laramie coal and lignite zone. The Denver lignite zone only occurs in the southern part of the basin and covers a much smaller area than the Laramie coal and lignite zone. Generalized stratigraphy at two points in the Denver lignite zone, which are representative of the two divisions of lignite-bearing areas suggested by Kirkham and Ladwig (1979, p. 63), are shown in figure 3.4.2-5. Kirkham and Ladwig (1979) suggest that the divisions of the Denver lignite zone be called the northern and southern lignite areas.

Lignite beds in the northern lignite area of the Denver lignite zone are normally about 10 to 15 feet thick, but they can be as much as 30 feet thick. These beds commonly contain numerous partings of claystone, shale, sandstone, and other noncoal sediment. Thickness of these beds decrease to the west. The western outcrop of the Denver Formation contains no known deposits of lignite (Kirkham and Ladwig, 1980, p. 64).

Lignite beds in the southern lignite area of the Denver lignite zone are generally thinner than lignite beds in the northern lignite area. The thickest bed is the Wolf bed (fig. 3.4.2-5), ranging from 18 to 28 feet thick, and lying from 25 to 75 feet below the top of the Denver Formation, at the eastern part of the southern lignite zone. The four other lignite beds below the Wolf bed are normally 5 to 10 feet thick, but can be more than 15 feet thick. Lignite beds deeper than the Bijou bed are generally very thin (Kirkham and Ladwig, 1980, p. 64).

Bituminous coal deposits in South Park (Park County, Colo.) occur in the Laramie Formation. Three coal seams were mined; the upper two seams varied in thickness from 4 to 6 feet, and the bottom seam varied in thickness from 7 to 40 feet (Washburne, 1908, p. 312). The coal seams dipped steeply and were difficult to get to, so that, when the easily accessible coal was gone, the mines were abandoned (Washburne, 1908, p. 307). 


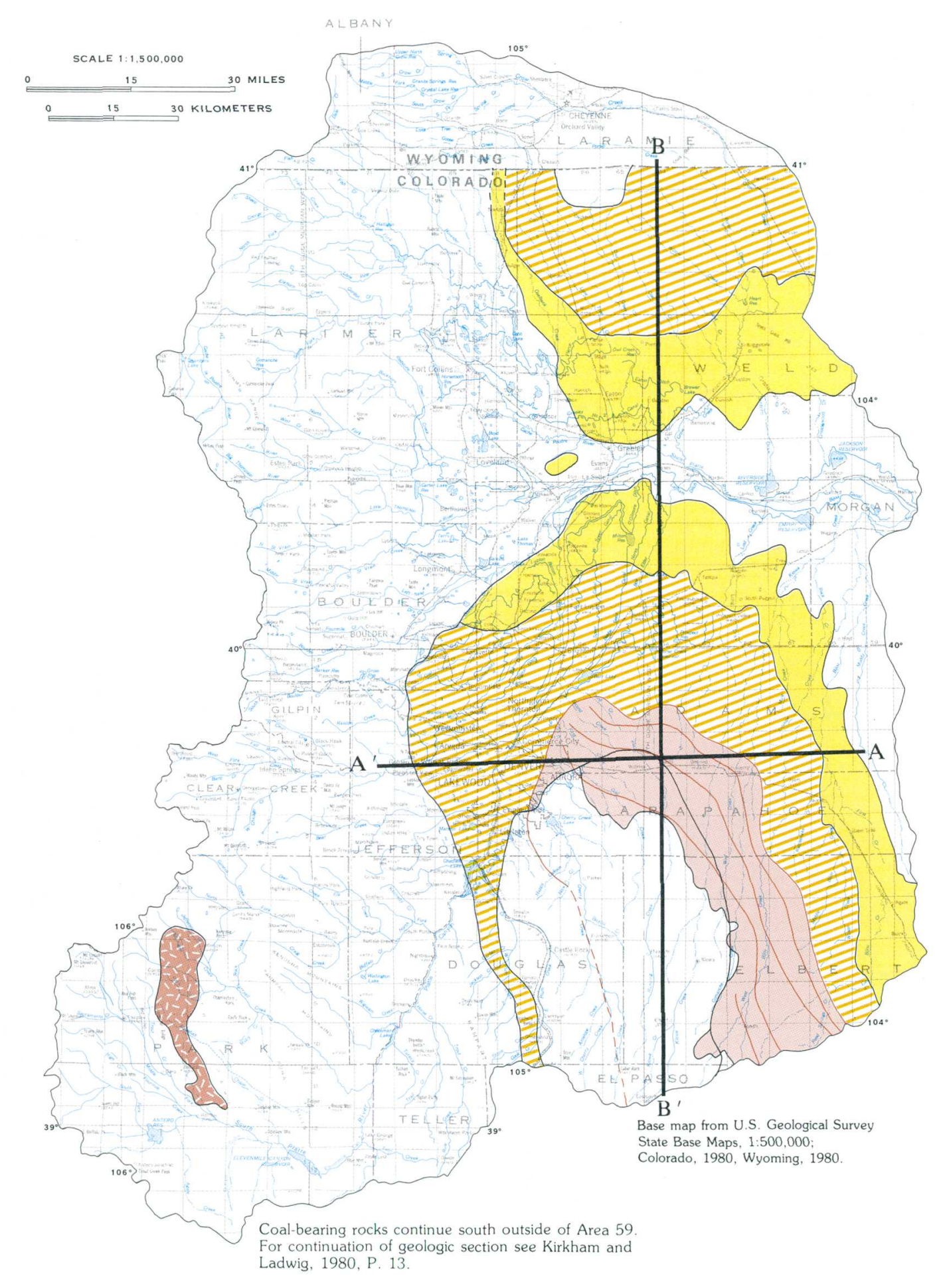

Figure 3.4.2-1 The coal and lignite-bearing formations and potential mining areas.
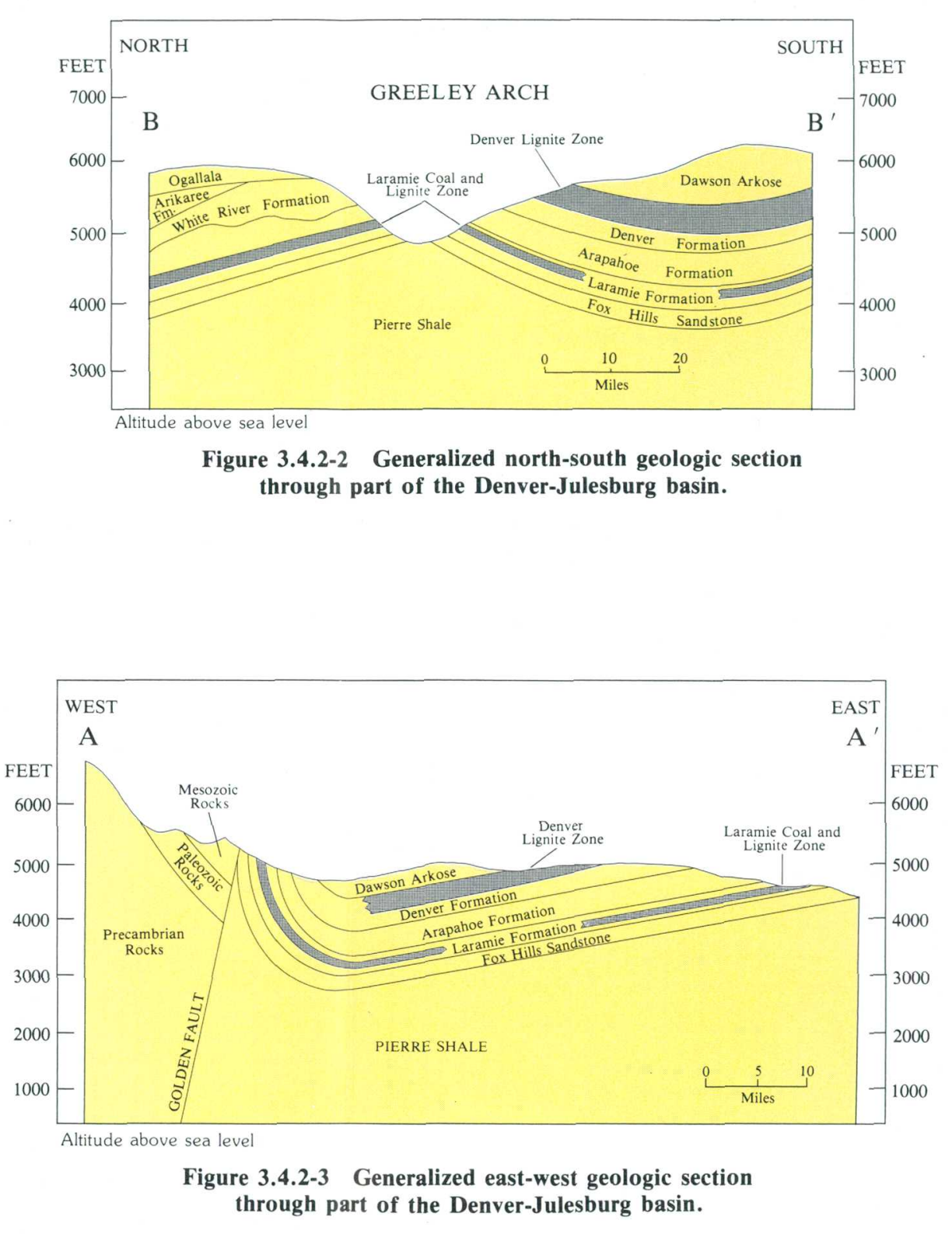

EXPLANATION

South Park coal-bearing region, Laramie Formation

Potential strippable areas, Laramie Formation

Potential areas suitable for underground mining or
in-situ gasification, Laramie Formation

Potential strippable areas, Denver Formation

Boundary of Denver Formation Lignite area (dashed where approximate)

Cal area boundaries. geologic sections and
stratigraphy modified from Kirkham and Ladwis

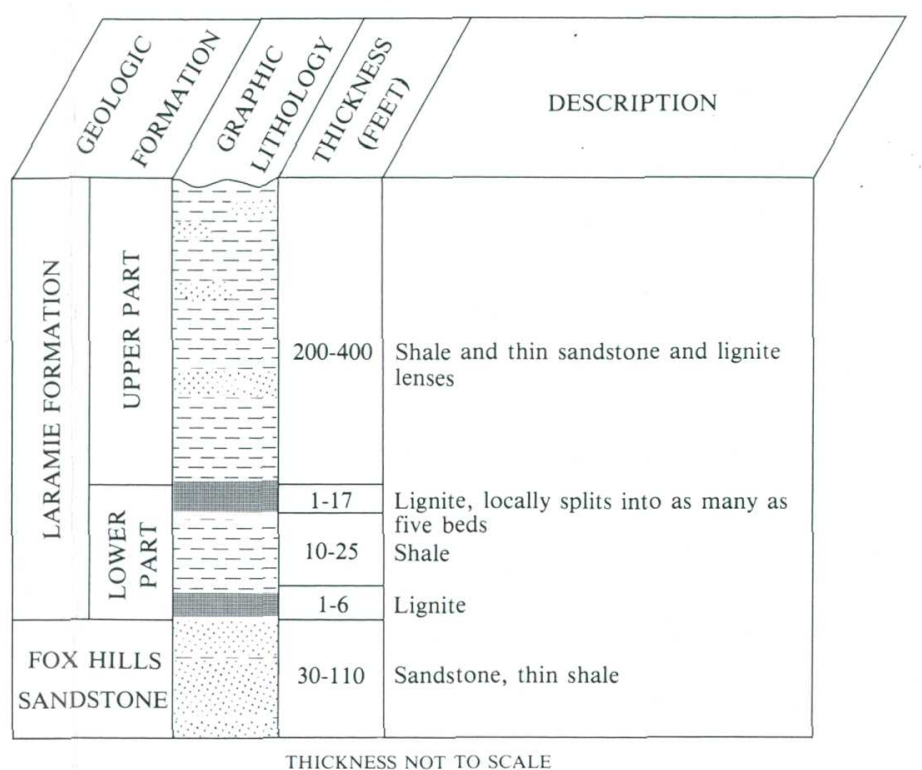

Figure 3.4.2-4 Generalized stratigraphy of the southern part of the

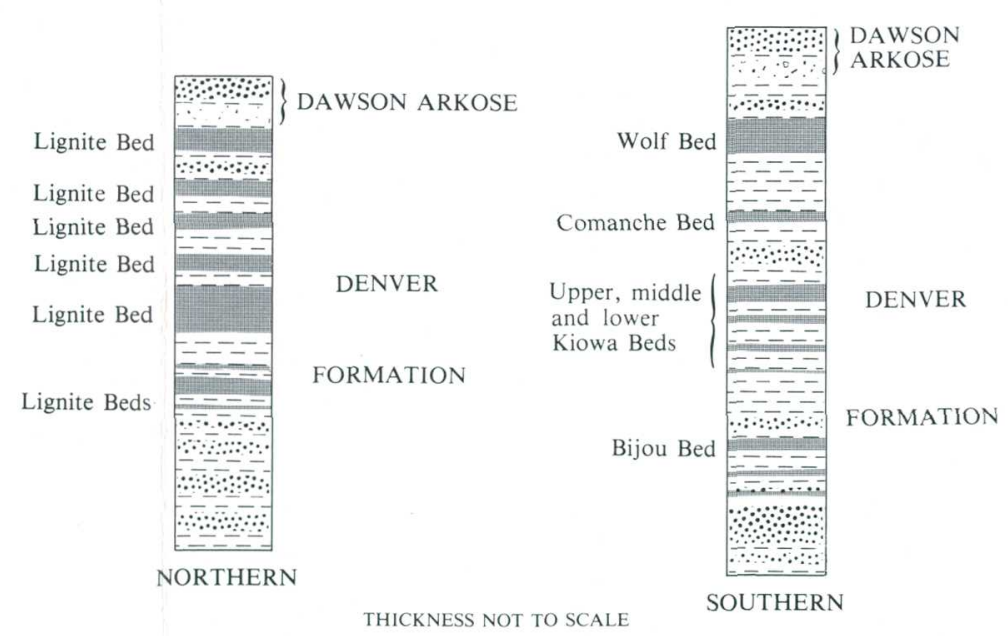

Figure 3.4.2-5 Generalized stratigraphy of the northern and southern lignite beds in the Denver Formation.

3.0 GENERAL FEATURES--Continued 3.4 Geology
3.4.2 Coal Deposits 


\title{
3.0 GENERAL FEATURES--Continued 3.5 Coal and Lignite mining
}

\section{Coal is being Mined at Only One Location in Area 59}

\author{
More than 130 million short tons of coal and lignite were \\ mined from the Denver basin and South Park from 1883 to 1979.
}

\begin{abstract}
Although accurate recordkeeping on coal mining goes back only to 1883 , coal mining began in Area 59 at a mine near Marshall, Colo. in the Boulder-Weld coal field about 1863. Since that time, coal and lignite mining spread throughout Area 59 (fig. 3.5-1). By 1905, coal mining in South Park (Park County) ceased, after more than 724 thousand short tons of coal had been produced for local use and the use of the Union Pacific Railroad. In 1979, the last operating underground mine in the Denver basin, the Lincoln Mine in the Boulder-Weld coal field, caught fire and had to be abandoned (Kirkham and Ladwig, 1980, p. 67). From 1883, when the Colorado State Coal Mine Inspector first began keeping accurate records, to 1979 , more than 130 million short tons of coal and lignite had been mined from the Denver basin and South Park. More than 99 percent of the coal was from underground mines (Kirkham and Ladwig, 1980).
\end{abstract}

In 1980, the Adolph Coors Company of Golden, Colo., started preparations for a strip mine north of Keenesburg, Colo. In 1982, a little more than 100,000 short tons of subbituminous coal were mined from a 5to 8-feet thick coal seam in the Laramie Formation (see fig. 3.5-1). The coal presently is used only for the energy needs of the Adolph Coors Company (Kirkham and Ladwig, 1980, and Don McDonald, Coors Energy Company, oral commun.,1983). This is the only mine presently operating in Area 59.

Total coal production from 1883 to 1979 in Area 59 is shown in figure 3.5-2. The greatest coal production was in Weld and Boulder Counties, mostly in the Boulder-Weld coal field. More than 75 million short tons were produced from mines in Weld County; whereas, mines in Boulder County produced more than 41 million short tons. Recoverable reserves in the two counties, assuming a 65 percent recovery factor, total more than 268 million short tons: Weld County has 216 million short tons and Boulder County has $\mathbf{5 2}$ million short tons. Extensive underground coal mining left many abandoned shafts, that have caused subsidence problems, and open shaft entrances, that are safety hazards in the Boulder-Weld coal field and in other coal-mining areas (Colorado Mined Land Reclamation Division, Inactive Mine Program, 1982).
Mines in El Paso County produced more than 16 million short tons of coal, placing the county after Weld and Boulder Counties in total coal production. Only one corner of El Paso County is in Area 59; however, because this coal-producing region is part of the Denver basin, it is included in this discussion. This region has more than 142 million short tons recoverable reserves.

In Jefferson County, more than 6 million short tons of coal were mined from shallow, steeply dipping coal beds in the Laramie Formation. The six remaining counties (fig. 3.5-2) produced less than 1 million short tons of coal. One of these six, Park County, produced 724,658 short tons of bituminous coal. These deposits were mined for only a short time, beginning about 1870 , and essentially ceasing about 1905 . Only seven mines were developed (Colorado Mined Land Reclamation Division, Inactive Mine Program, 1982, p. 30-1 and p. 30-14). The largest operation was near the town of Como, Colo., where the Union Pacific Railroad operated coal mines to supply coal to power their trains from 1875 to 1893 (Washburne, 1908, p. 312).

Planned future development of subbituminous coal and lignite resources in the Denver basin is generally limited to surface mining. Of several areas where surface mining was proposed, only Coors Energy Company is producing coal. The proposed Bacon mine, which is in El Paso County south of Area 59, has all the required permits, but the mine is not yet producing coal. Widespread underground mining of the subbituminous coal in the Laramie Formation is unlikely because this method of mining probably would not be profitable. However, some companies are interested in mining subbituminous coal underground (Kirkham and Ladwig, 1980 , p. 72). Underground gasification is another method that is being considered for recovery of the abundant coal and lignite reserves south and east of Denver (Soister, 1974 and 1982). However, possible environmental problems associated with this method would have to be solved before it could be used. There are no plans to develop the bituminous coal deposits in South Park. 


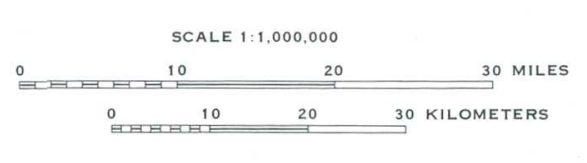

N

EXPLANATION

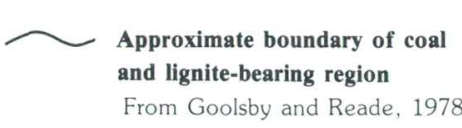

Former coal-mining area

Fromer coal-mining area
Drom Colorado Mined Land Reclamation
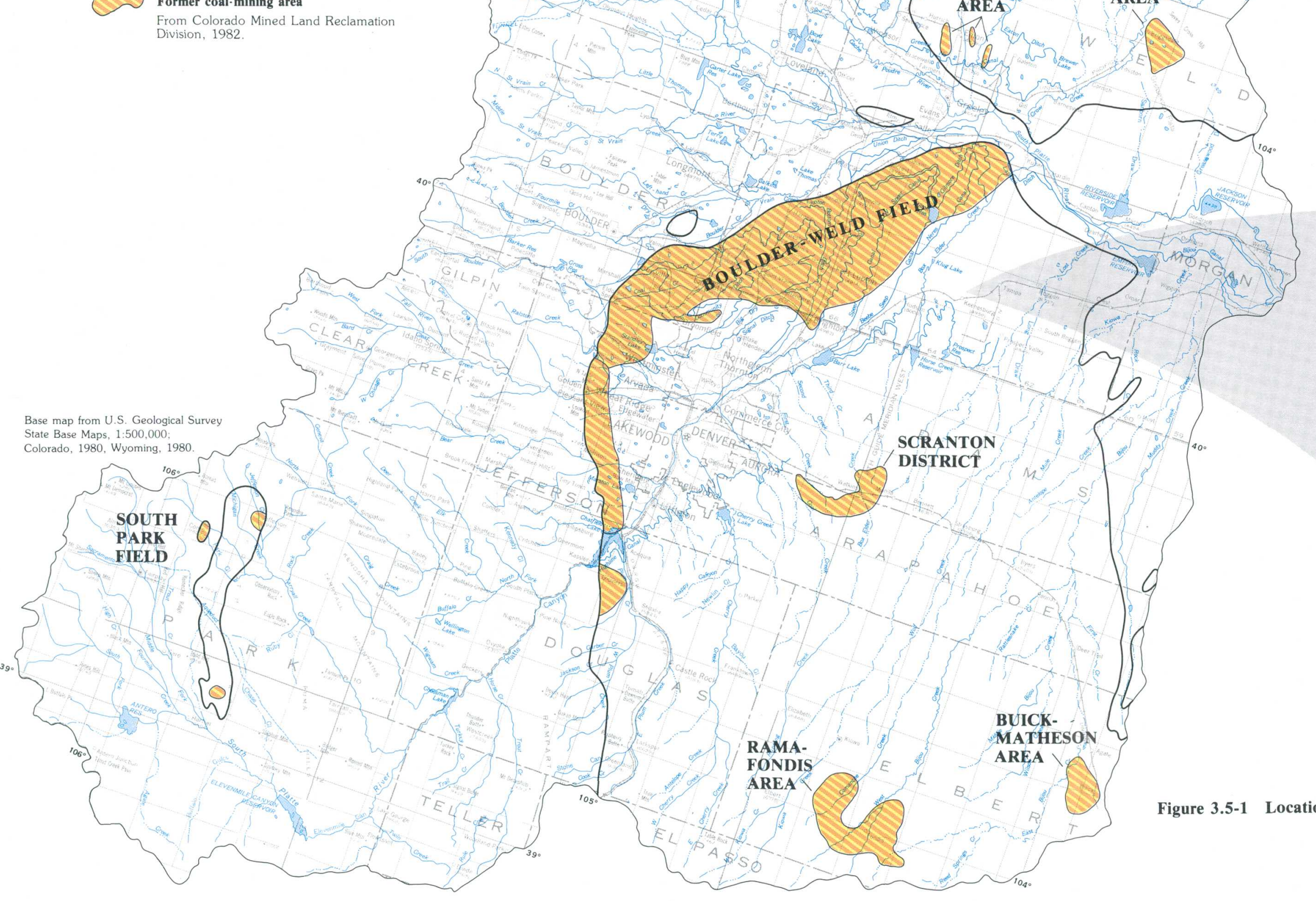

$\underset{\text { MATHESON }}{\text { BUICK- }}$ AREA
RAMA-
FONDIS
AREA
REA
COPOMAT

\section{W WELLINGTON}

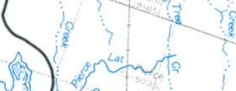

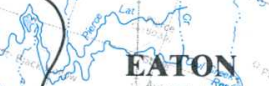

$\begin{array}{lll}\text { BRIGSDAM } & \text { AREA } \\ \text { AREA }\end{array}$

AREA

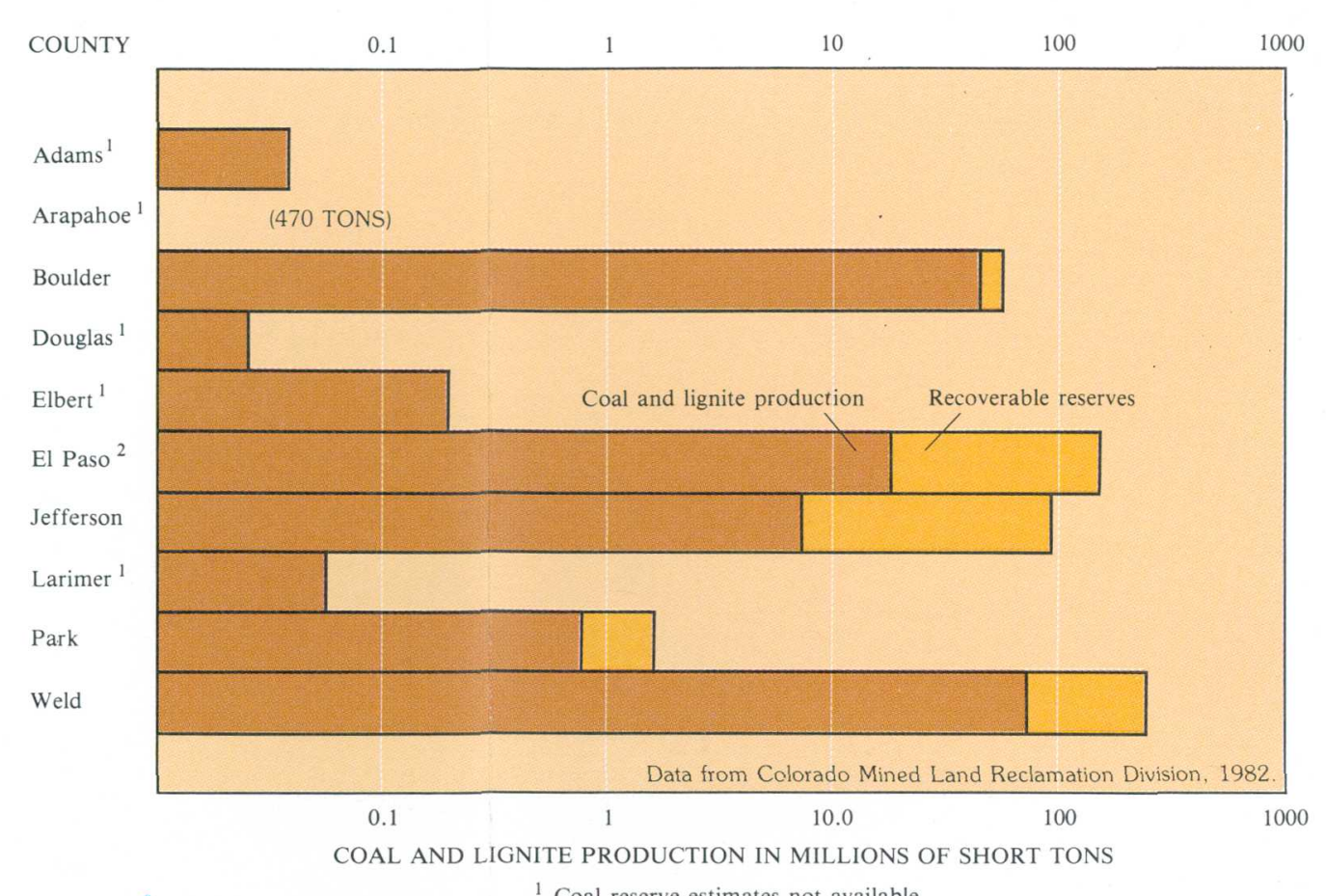

COAL AND LIGNTE PRODUCTION IN MHLIONS OF SHORT TONS

$$
\begin{aligned}
& \text { Coal reserve estimates not available } \\
& \text { Outside Area } 59
\end{aligned}
$$

Figure 3.5-2 Total coal and lignite production in 1883-1979, and recoverable reserves (65 percent recovery).

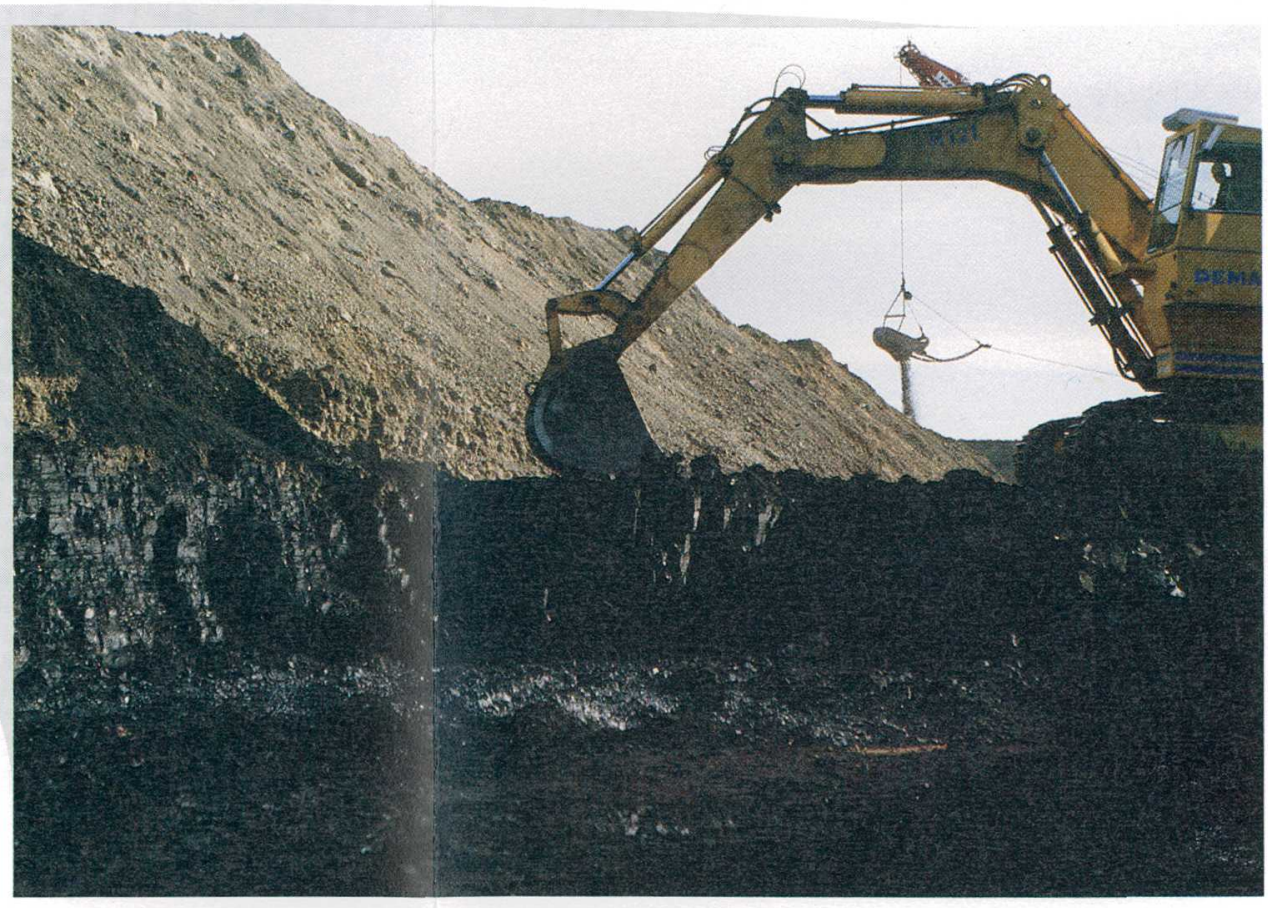

The Coors Energy Company's surface coal mine near Keenesburg, Colorado. Sub bituminous coal is being taken from the Laramie Formation. 


\title{
3.0 GENERAL FEATURES--Continued 3.6 Climate
}

\section{Altitude is Dominant Factor in Climate of Area}

\author{
Average annual precipitation ranges from less than 10 inches \\ on the plains to more than $\mathbf{4 0}$ inches on the mountains.
}

Some of the most varied climate in the United States is found in Area 59, because of the more than 9,000 feet of relief from the eastern plains to the alpine regions of the western mountains. Most of Area 59 receives less than 16 inches of precipitation per year. Average annual precipitation ranges from less than 10 inches in the Crow Creek Valley northeast of Greeley, Colo., and in and around Antero Reservoir in South Park, to more than 40 inches on and near the Continental Divide (fig. 3.6-1) (U.S. Weather Bureau, 1967).

Mountain ranges along the western edge of Area 59 have a major influence on the weather. Because the prevailing winds are normally from the west, most weather systems come from the west, drawing their moisture from the Pacific Ocean. As these systems gain altitude crossing the Rocky Mountains, the air cools and loses its moisture on the western slope and the Continental Divide. The eastern slope and the plains receive little moisture from these systems. For example, Estes Park, in the northern mountains, receives about 16 inches of precipitation per year; while about 12 miles west, on the Continental Divide, the average annual precipitation is more than 40 inches. During the fall and winter, however, cold dry fronts from the north occasionally move into eastern Wyoming and Colorado. If moisture from the Gulf of Mexico is present at the same time, the result is a high-plains blizzard. Driving heavy snow and cold temperatures cover the plains and the lower altitudes of the foothills during these storms; while the mountains further west have relatively mild weather, because the cold air mass is too shallow to reach the higher altitudes.

Other high mountains, not a part of the ranges on the western border of Area 59, influence the amount of local precipitation. Some examples of the effects of these mountains on local average annual precipitation are: the Mummy Range, northwest of Estes Park, Colo., which receives more than 40 inches; the Puma Hills, northeast of Eleven Mile Reservoir in South Park, Colo., which receives more than 20 inches; and the 14,110 feethigh Pikes Peak (not on map), 20 miles southeast of the Palmer Divide, which is the source of the finger-shaped area of more than 16 inches extending over the Palmer Ridge.

The air temperature in Area 59 is more mild than might be expected from the extreme altitude changes, since temperature ordinarily decreases with altitude at a lapse rate of about $3^{\circ}$ to $5^{\circ} \mathrm{F}$ per thousand feet (Hansen and others, 1978, p. 10). Graphs showing the monthly maximum, average high, average, average low, and minimum temperatures for five towns and cities are shown in figure 3.6-1. These are only representative temperatures, and they do not indicate the large temperature change that can occur, for example, between the bottom of a cold mountain canyon and the top of a warmer high cliff nearby. Generally, all sites have a maximum temperature of more than $100^{\circ} \mathrm{F}$ and a minimum temperature of $-30^{\circ} \mathrm{F}$. The average temperature in Area 59 increases from west to east, and on the plains from north to south. Factors that are important in keeping the temperatures mild are the low humidity that allows the air to warm rapidly and to "feel" warmer, and high-velocity chinook winds that blow from the mountains to the plains, warming as they lose altitude. 


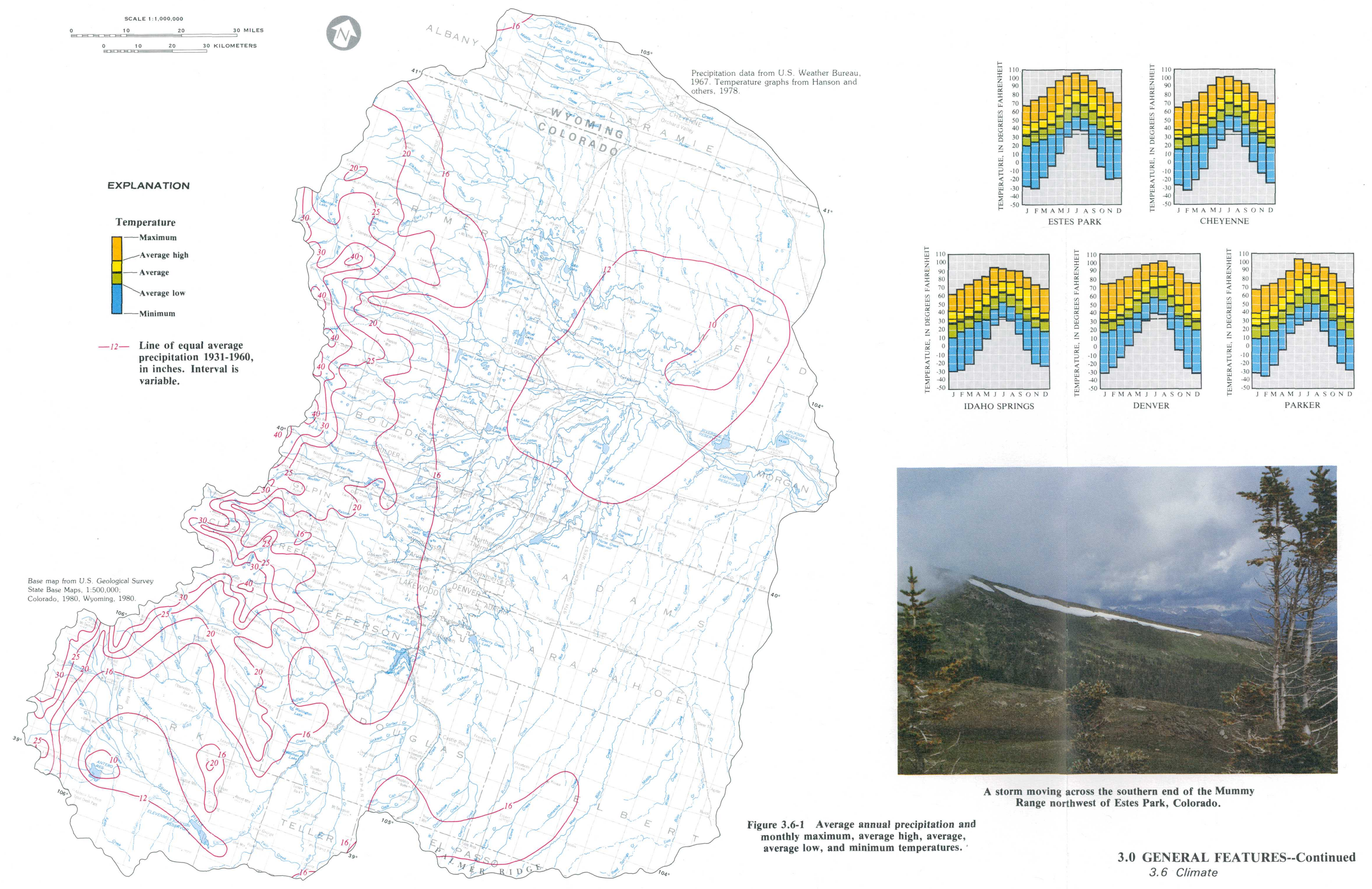




\title{
4.0 WATER USE \\ 4.1 Classification of Surface Water Based on Recreational, Water Supply, and Agricultural Uses
}

\section{Classes of Surface Water have Diverse Use Classifications that are Geographically Related}

\author{
Surface waters are classified according to suitable uses that vary markedly between an \\ area in and west of the Front Range and the Great Plains. Higher quality waters \\ (suitable for drinking and other uses) occur west of the Front Range; lower quality \\ waters (generally suitable only for agriculture) occur in the Great Plains.
}

Those surface waters in Colorado suitable for recreation, water supply, and agricultural uses are shown in figure 4.1-1. Waters are classified according to the uses for which they are presently suitable or intended to become suitable, as designated by the Colorado Department of Health (1979). A marked change of classified use occurs within the study area; a higher use classification exists for water in and west of the Front Range, and a lower use classification exists for waters in the Great Plains (fig. 4.1-1).

The highest classification is "high-quality," which designates waters that are of quality higher than necessary to support primary-contact recreation and propagation of aquatic life, and which are also suitable for agriculture and domestic water supplies. The high-quality classification precludes the necessity to classify for other beneficial uses. Class 1 designates high-quality waters of ex- ceptional recreational and ecological significance, such as waters in National and State parks and forests. These waters will be protected and maintained at their existing quality. Class 2 designates those other high-quality waters, which are not classified as outstanding or national-resource waters. These waters will be maintained and protected at their existing quality, unless changed as a result of justifiable economic or social development. However, water-quality degradation of these stream reaches may not become injurious to existing water uses. Recreation Class 1 waters are designated as being suitable for primary contact or recreational activity, such as swimming, when the injestion of small quantities of water is likely to occur. Class 2 waters are suitable for recreational uses that are not included in the primarycontact subcategory. Waters are finally designated, as suitable or unsuitable for agricultural and water-supply uses. 


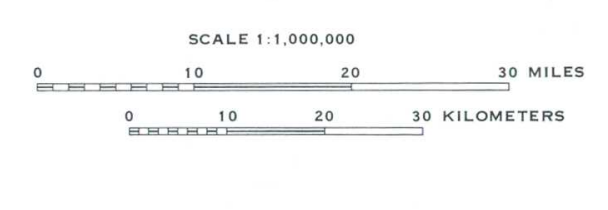

EXPLANATION

SURFACE WATER USE CLASSIFICATION
IN DESCENDING ORDER OF QUALITY High quality waters

Class 1

Lower quality water

- Recreation class 1, water supply,

- Recreation class 2 , water supply.

agriculture

(2)

Recreation class 2 , agriculture

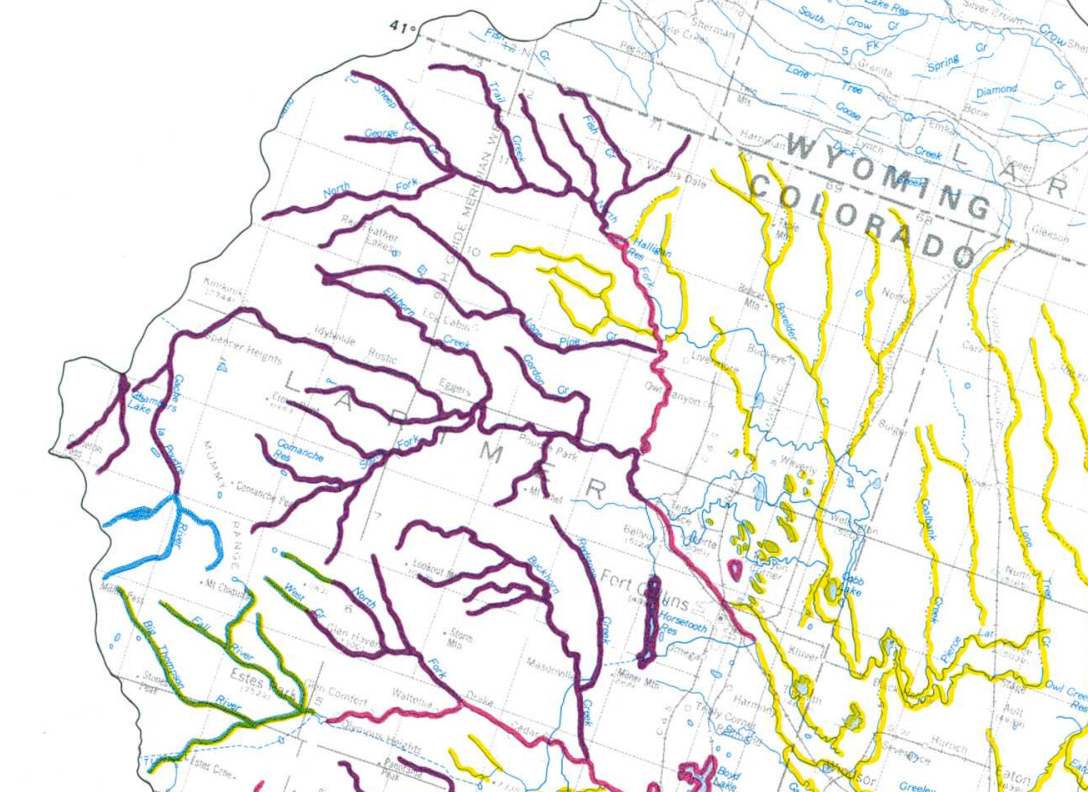

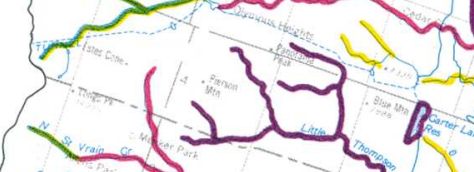
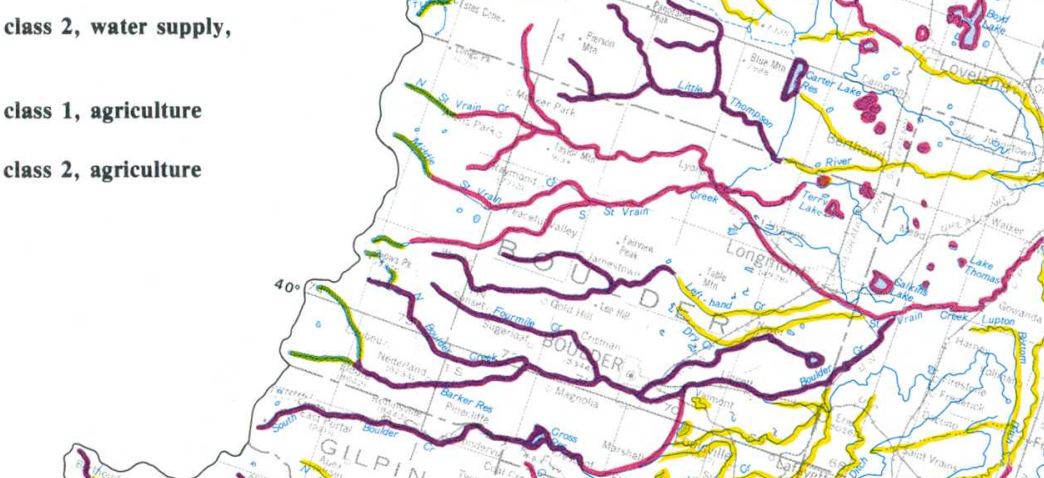

$\{1 / 1)$

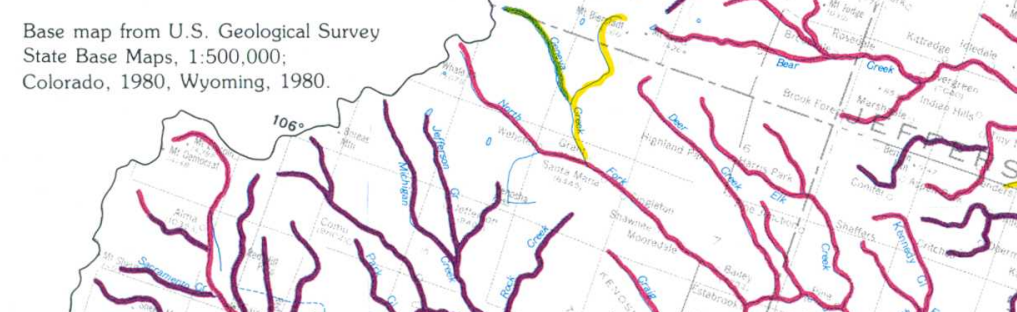

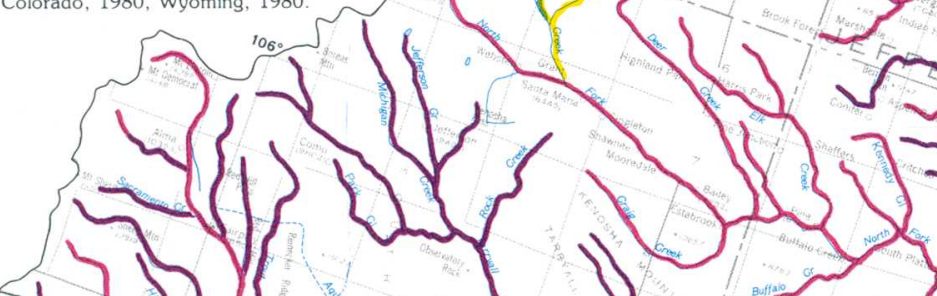

5

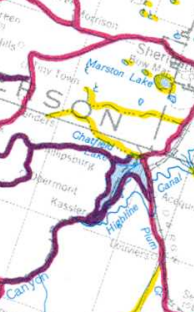

atio $\rightarrow$ -
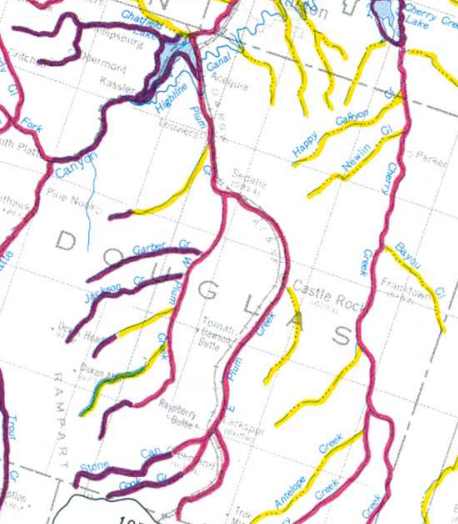

10.0

\}

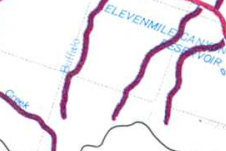

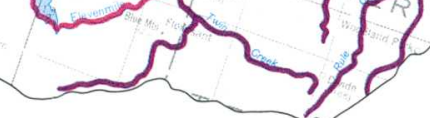

.

Figure 4.1-1 Classification of surface water based on recreational, water supply, and agricultural uses.

\subsection{WATER USE}

4.1 Classification of Surface Water Based on Recreational, Water Supply, and Agricultural Use 


\title{
4.0 WATER USE--Continued \\ 4.2 Classification of Surface Water for Use by Aquatic Life
}

\section{Surface Waters in Area 59 have Diverse Aquatic-Life Use Classifications that are Geographically Related}

\author{
Surface water in and west of the Front Range is generally classified as suitable for \\ maintainence of cold-water biota; whereas, in the Great Plains, surface water is \\ generally classified as suitable for maintainance of warm-water biota.
}

Those surface waters in Colorado and Wyoming that are suitable for the protection and maintenance of aquatic life are shown in figure 4.2-1. Waters are classified according to the aquatic life uses for which they are presently suitable or intended to become suitable, as designated by the Colorado Department of Health (1979) and the Wyoming Department of Environmental Quality (1979). A marked change of aquatic life use occurs within the study area; coldwater biota designations are associated with waters in and west of the Front Range, and warmwater biota designations are associated with waters on the Great Plains.

Class 1 (cold) and Class 1 (warm) are those waters in Colorado that provide a habitat suitable for maintaining a wide variety of coldwater biota or warm-water biota, including sensitive species. Class 2 (cold) and Class 2 (warm) waters are those areas where the potential variety of life forms is presently limited primarily by flow and streambed characteristics.

Two classifications are given for surface waters in Wyoming (fig. 4.2-1). Class 3 waters are those that are determined by the Wyoming Game and Fish Department to be presently supporting nongame fish, or have the hydrologic and natural water-quality potential to support nongame fish. Class 4 waters are those that do not have the hydrologic or natural water-quality potential to support fish. 


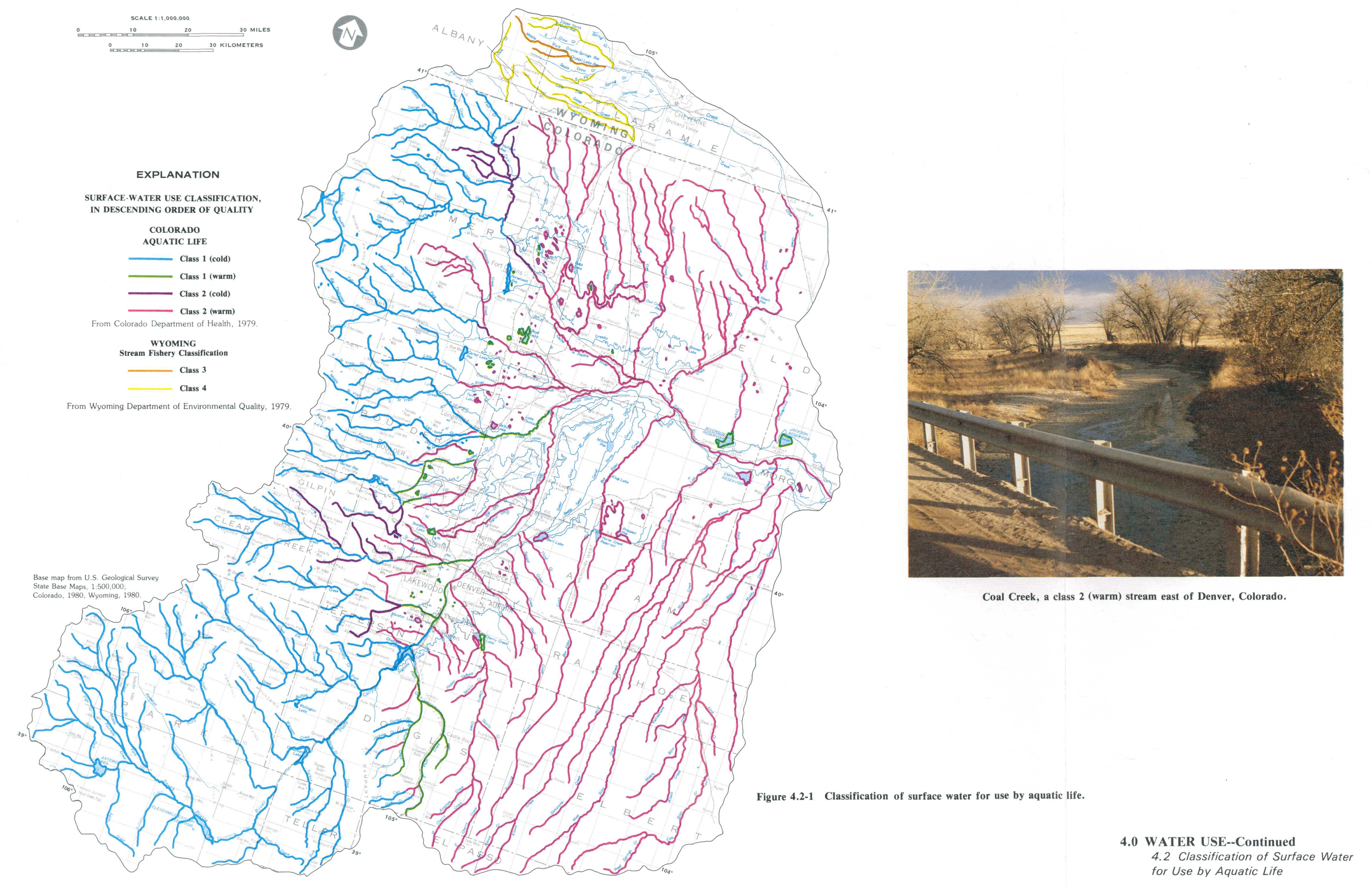




\subsection{WATER USE--Continued}

4.3 Surface-Water Storage (Lakes and Reservoirs)

\section{Lakes and Reservoirs in Area 59 Vary Greatly in Size, Storage Capacity, and Water Use}

\section{Surface areas of lakes and reservoirs in Area 59 range from less than one acre for many stock ponds to 4,800 acres for Chatfield Lake in Jefferson County, Colorado, which is used for flood control and recreation.}

Eighty selected lakes and reservoirs in the study area having a surface area greater than 100 acres are shown in figure 4.3-1. The number by the lake (fig. 4.3-1) corresponds to the number in section 12.2 in the "Supplemental Information" section of this report. Chatfield Lake in Jefferson County has the largest surface area $(4,800$ acres $)$ and also has the greatest capacity $(235,000$ acrefeet). Sixty-five percent of the lakes shown are in Boulder and Larimer Counties, areas of rapid urban development, which also are areas noted for irrigated farmland.

In the past, many of these lakes were used primarily for irrigation and domestic uses. However, because of recent urban development along the Front Range, some lakes also have been used for recreation, power, and centers of realestate development. These same lakes are threatened with a general deterioration of chemical and biological quality caused by heavy use and development of the surrounding area (Ficke and Danielson, 1973; Danielson, 1975). Some lakes, however, have restrictions on their use for recreation; other lakes are not open for public use.

In addition to the lakes listed here, there are more than 300 smaller lakes in the study area. Most of these smaller lakes are owned by individuals or by irrigation and ditch companies; they are not normally accessible to the public. 


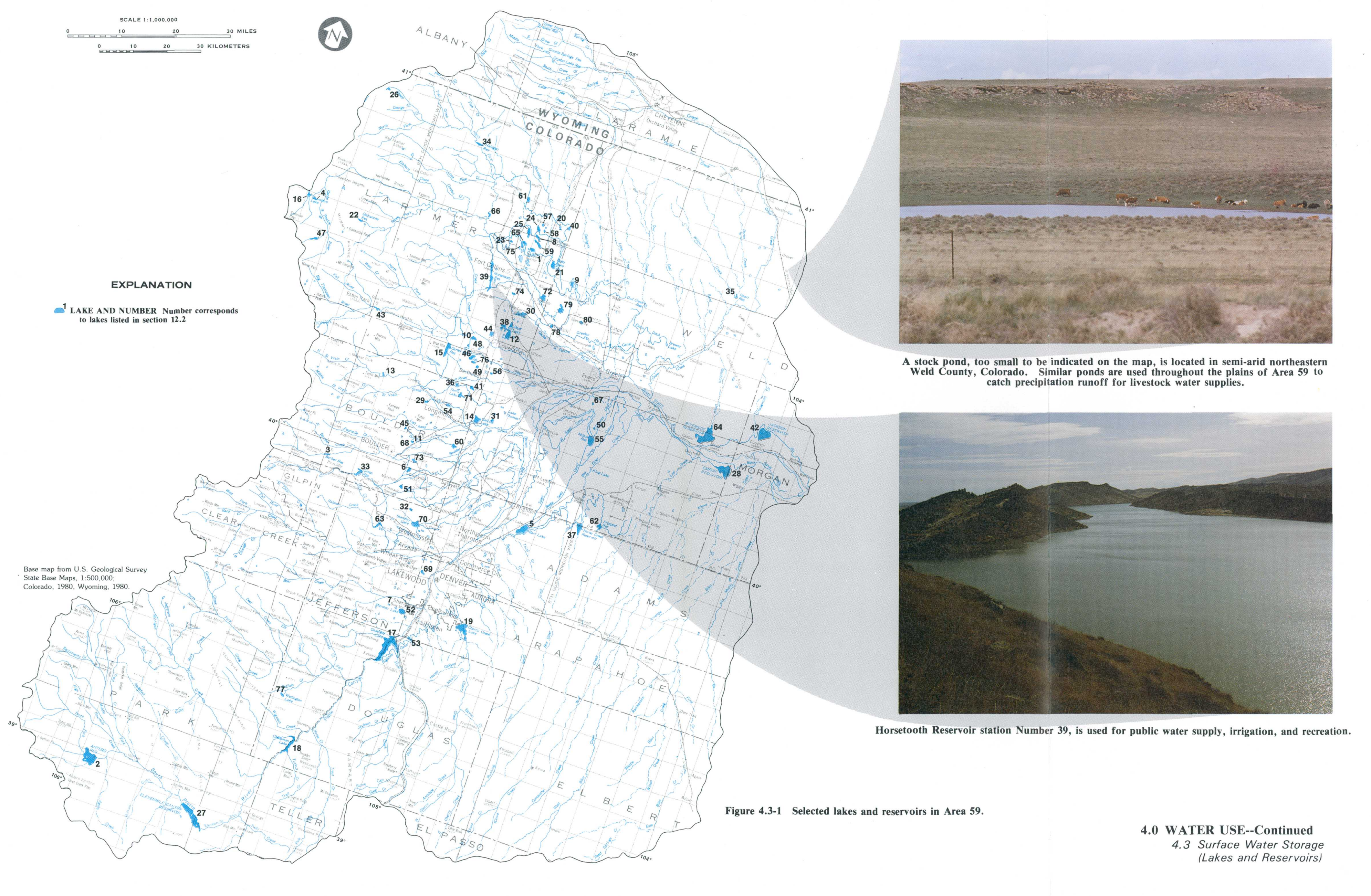




\title{
5.0 SURFACE-WATER HYDROLOGIC NETWORK
}

\section{Streamflow Information Available for 213 Locations}

\author{
Streamflow information is being collected currently at \\ 83 locations, 10 of which are also water-quality stations.
}

Streamflow information is available for 213 locations within Area 59, of which 83 are active hydrologic stations. Locations of the surface-water stations are shown on figure 5.0-1; pertinent data are listed in section 12.1, in the "Supplemental Information" section. The area has the oldest streamflow-gaging station in Colorado and Wyoming; (station 176, fig. 5.0-1) on the Cache la Poudre River at mouth of canyon near Fort Collins, Colo., established on June 20, 1881. Since that time, the streamflow-hydrologic network has expanded considerably to meet the needs of irrigation, municipal, and industrial water use. Many of the stations established during the past century are no longer active; in more recent years, numerous partial-record stations have been established, primarily to provide information on floods.

Continuous or seasonal records of streamflow quantity are obtained at 58 of the active stations; water-quality information also is obtained at 10 of these stations. Fifteen of the stations are partialrecord stations, where records of annual peak flow are obtained for use in flood studies. At the remaining 10 stations, records of transmountain diversions from the Arkansas and Colorado River basins to the Platte River basin are obtained. In addition to the stations shown in figure 5.0-1, there are numerous miscellaneous sites and partial-record stations in Area 59, at which measurements are made in times of drought or flood.
Much of the data for the streamflow-gaging stations, including the miscellaneous sites, has been published in annual U.S. Geological Survey reports, "Water Resources Data for Colorado" and "Water Resources Data for Wyoming." Much of the data for the partial-record stations has been published in consecutive tri-annual reports commencing in 1972, (Ducret and Hodges, 1972 and 1975; Cochran and others, 1979 and 1983). These data are also available from computer storage through the National Water-Data Exchange (NAWDEX) and the National Water-Data Storage and Retrieval System (WATSTORE), described elsewhere in this report.

Because of increasing interest in hydrologic information, new hydrologic projects periodically may be started or existing projects expanded, which frequently results in the establishment of new streamflow data-collection stations. Information concerning current activities may be obtained from the U.S. Geological Survey, Water Resources Division, Colorado District, MS 415, Lakewood, CO 80225, and the U.S. Geological Survey, Water Resources Division, Wyoming District, P.O. Box 1125, Cheyenne, WY 82003. 


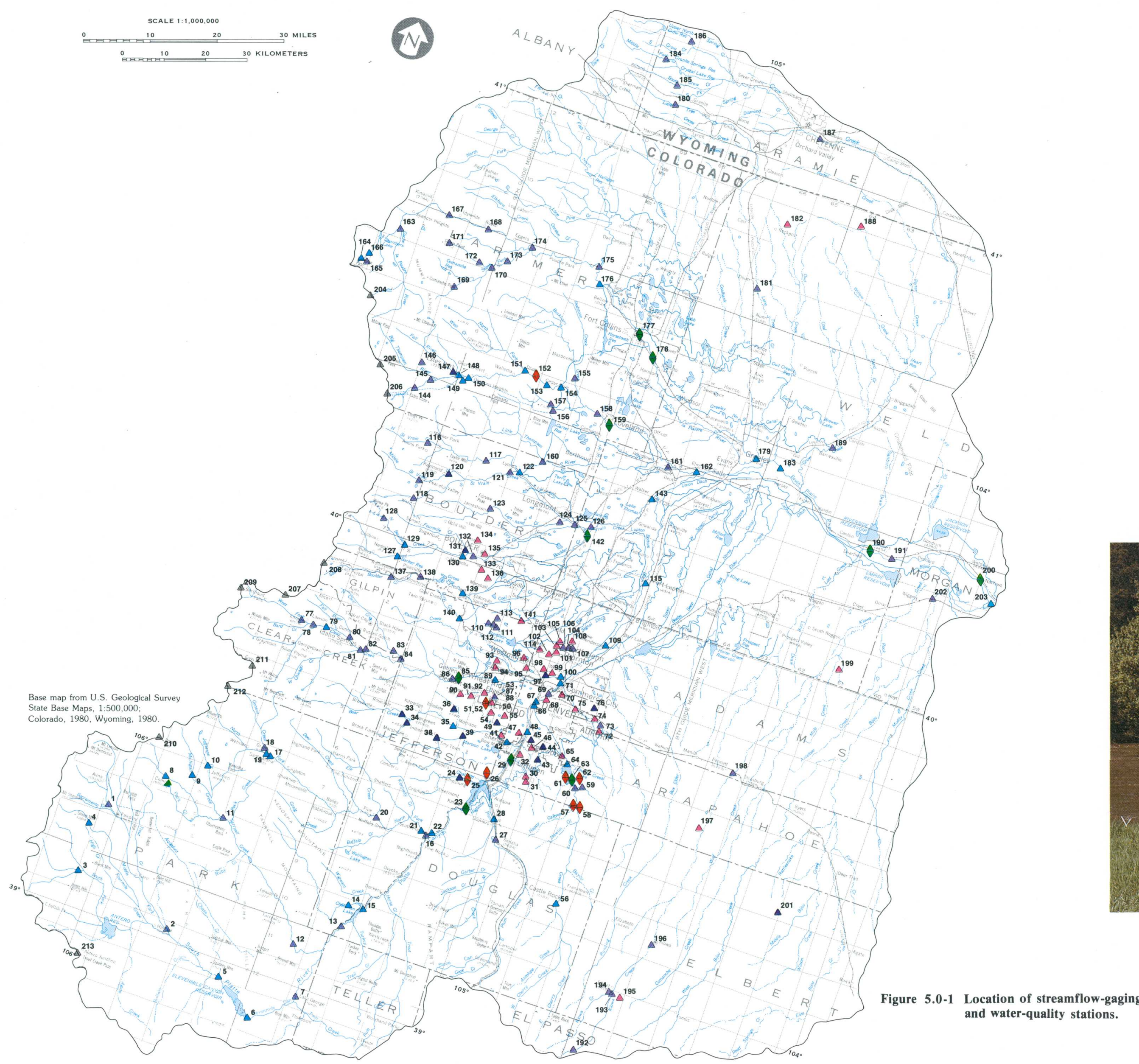

EXPLANATION

ACTIVE STREAMFLOW-GAGING STATION

- ACtive STREAMFLOW-GAGiNg AND WATER-QUaLtTy STATION

A INACTIVE STREAMFLOW-GAGING STATION

- INACTIVE STREAMFLOW-GAGING AND WATER-QUALITY STATION

active PEAK-FLOW STATION

$\triangle$ INACTIVE PEAK-FLOW STATION

$\triangle$ TRANSMOUNTAIN DIVERSION STATION

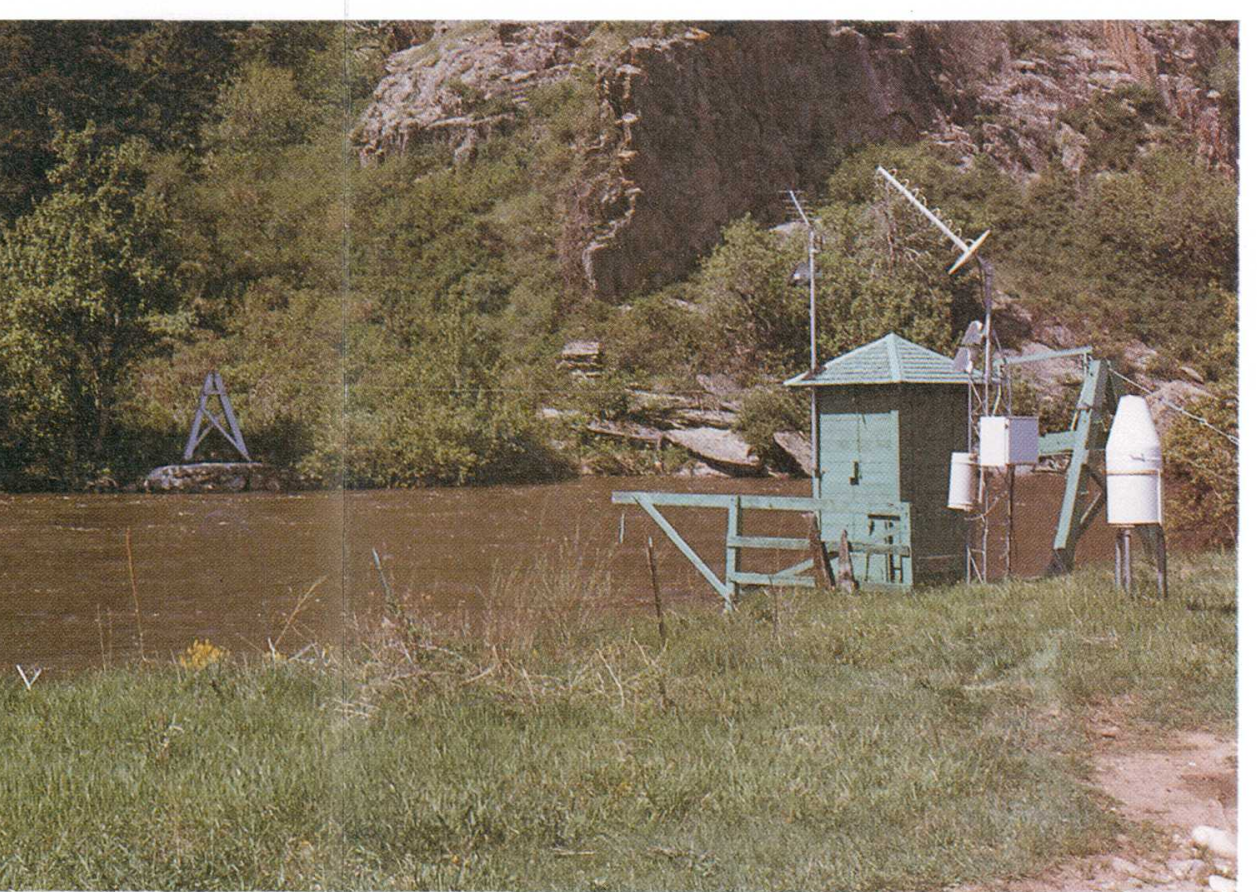

Established in 1881, this streamflow-gaging station on the Cache La Poudre 


\title{
6.0 SURFACE-WATER QUANTITY \\ 6.1 Streamflow Variability \\ 6.1.1 Flow Duration
}

\section{Streamflow Sustained Primarily by Ground-Water Discharge}

\author{
Climatic, hydrologic, and geologic characteristics of drainage basins, \\ as well as regulation, affect streamflow duration.
}

Flow-duration curves are cumulative-frequency curves, showing the percentage of time that specified discharges were equaled or exceeded in a given period. The shape of a flowduration curve reflects the climatic, hydrologic, and geologic characteristics of a drainage basin, and it is useful in evaluating the availability and variability of future flows. A curve having a steep slope throughout indicates highly variable flow derived primarily from direct surface runoff; a curve having a flat slope indicates flow derived from delayed surface runoff or groundwater storage. A flat slope at the lower end of the curve indicates sustained base flow; a steep slope indicates negligible base flow (Searcy, 1959, p. 22). Flow-duration curves for a station on $\mathrm{Bi}$ jou Creek, an ephemeral stream, and for a station on each of three perennial streams, the Big Thompson, Cache la Poudre, and South Platte Rivers (fig. 6.1.1-1), are presented in figure 6.1.1-2.

The flow-duration curve for station 202 (fig. 6.1.1-2) Bijou Creek near Wiggins, Colo., has a very steep slope, because streamflow is derived primarily from runoff resulting from summer thunderstorms. Although these thunderstorms occasionally may be intense, and widespread enough to produce very large streamflows, their generally short duration, coupled with the overall lack of precipitation in the plains, is insufficient to provide continued recharge to the alluvium. Thus, ground-water discharge is not available to sustain streamflow, even though the Bijou Creek basin upstream from station 202 contains large deposits of alluvium; ephemeral streams in the semiarid plains, such as Bijou Creek, are characterized by extended periods of no-flow.

The flow-duration curve for station 202 is only for a 6-year period (1951-1956); it should be considered to be representative of only that period. Because discharge in ephemeral streams can be highly variable from one year to the next, a long period of record often is needed to adequately define long-term flowduration patterns. The flow-duration curve for a longer period of record at station 202 probably would be somewhat different than that depicted in figure 6.1.1-2, especially with respect to the larger discharges.

Although two of the three perennial streams have a long period of record (more than 75 years), a uniform time period, 1954-1978, was selected for analysis in this section of the report, and in the next two sections. Hydrologic, climatic, and wateruse patterns have not changed significantly during this period, allowing better comparison of the flow-duration curves. Also, assuming that these conditions do not change significantly in the future, the curves depicted for the three perennial streams should be indicative of the availability and variability of future flows at these locations.

Streamflow at station 148 (fig. 6.1.1-1) Big Thompson River at Estes Park, Colo., is basically natural because only very minor diversions are present upstream from the station. At station 176 Cache la Poudre River at mouth of canyon near Fort Collins, Colo., streamflow is affected by diversion to irrigation canals and regulation by reservoirs to a greater extent. Reservoirs regulate the amount of water they release to a stream, depending on the amount of water in the reservoir, the time of year, and other factors. Nevertheless, since both basins are in the mountains and most streamflow results from snowmelt, the flow-duration curves for stations 148 and 176 are similar in shape (fig. 6.1.1-2). The flattened slopes on the upper ends of these two curves generally is a characteristic of streams that derive their high flows from snowmelt (Searcy, 1959, p. 22). Greater precipitation in the mountains, as much as 40 inches annually, in conjunction with spring and summer snowmelt, also recharges the alluvium in and adjacent to these mountain streams. The quantity of recharge is sufficient to provide groundwater discharge to the streams, sustaining streamflow, as indicated by the flattened slopes of the flow-duration curves for stations 148 and 176.

Streamflow at station 183 South Platte River near Kersey, Colo., also is derived primarily from snowmelt in the mountains; however, the shape of the flow-duration curve for this station is considerably different than the curves for stations 148 and 176 (fig. 6.1.1-2). Assuming that all other factors affecting flow duration are constant, the primary effect of drainage-area differences is to alter the position of the curves. Therefore, other factors, in addition to a much larger drainage basin, are affecting the flow-duration pattern for station 183. Storage of streamflow in numerous reservoirs, to be released at some later date to augment existing streamflow, diversion for irrigation, direct irrigation-return flow, and increased recharge because of irrigation, are some of the factors affecting streamflow at station 183. In addition, the presence of large metropolitan areas in Colorado, such as Denver, Boulder, and Fort Collins, also affect streamflow: as an example, by increasing runoff from either snowmelt or rainfall, because of the large amounts of impervious area. 


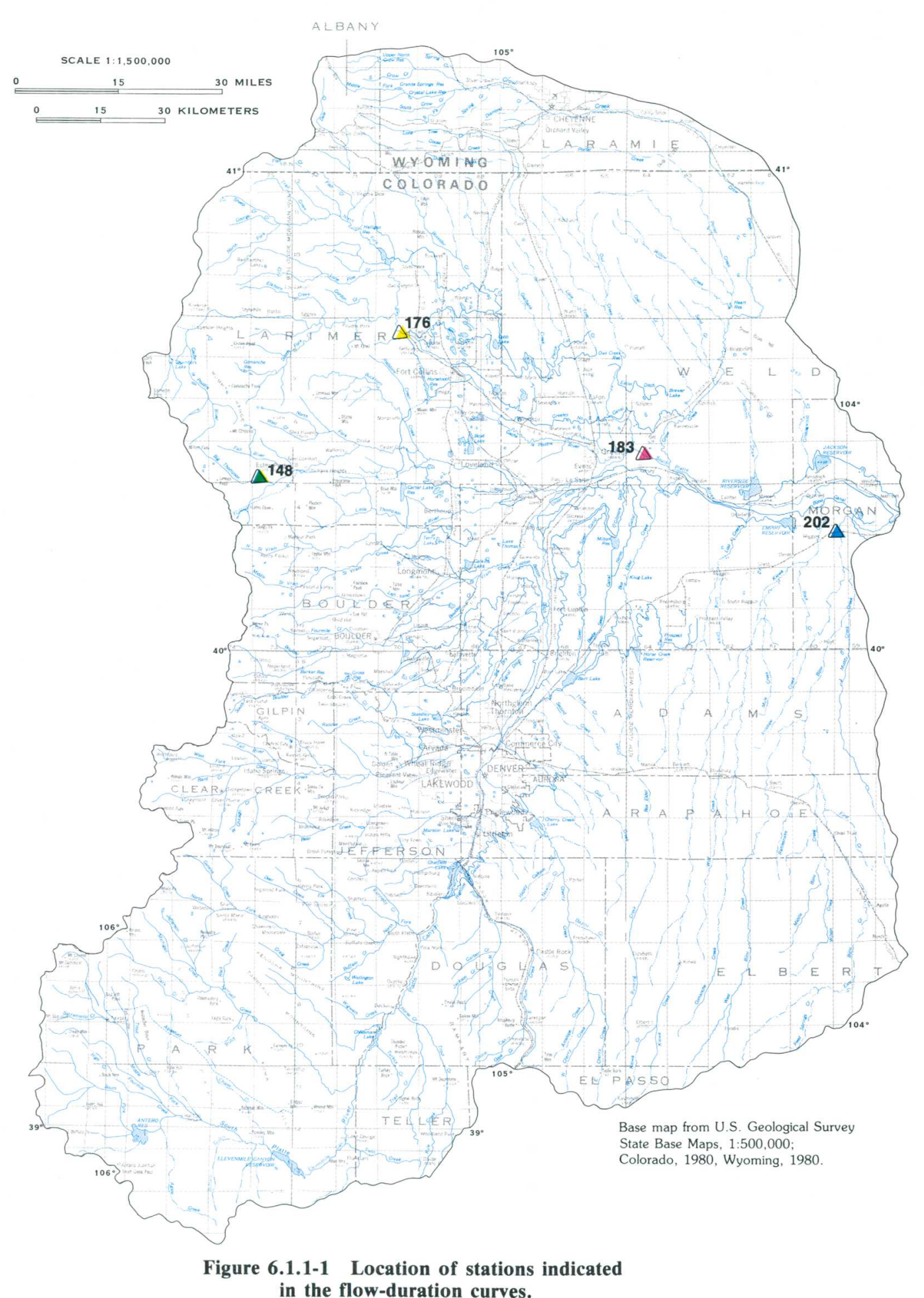

in the flow-duration curves.

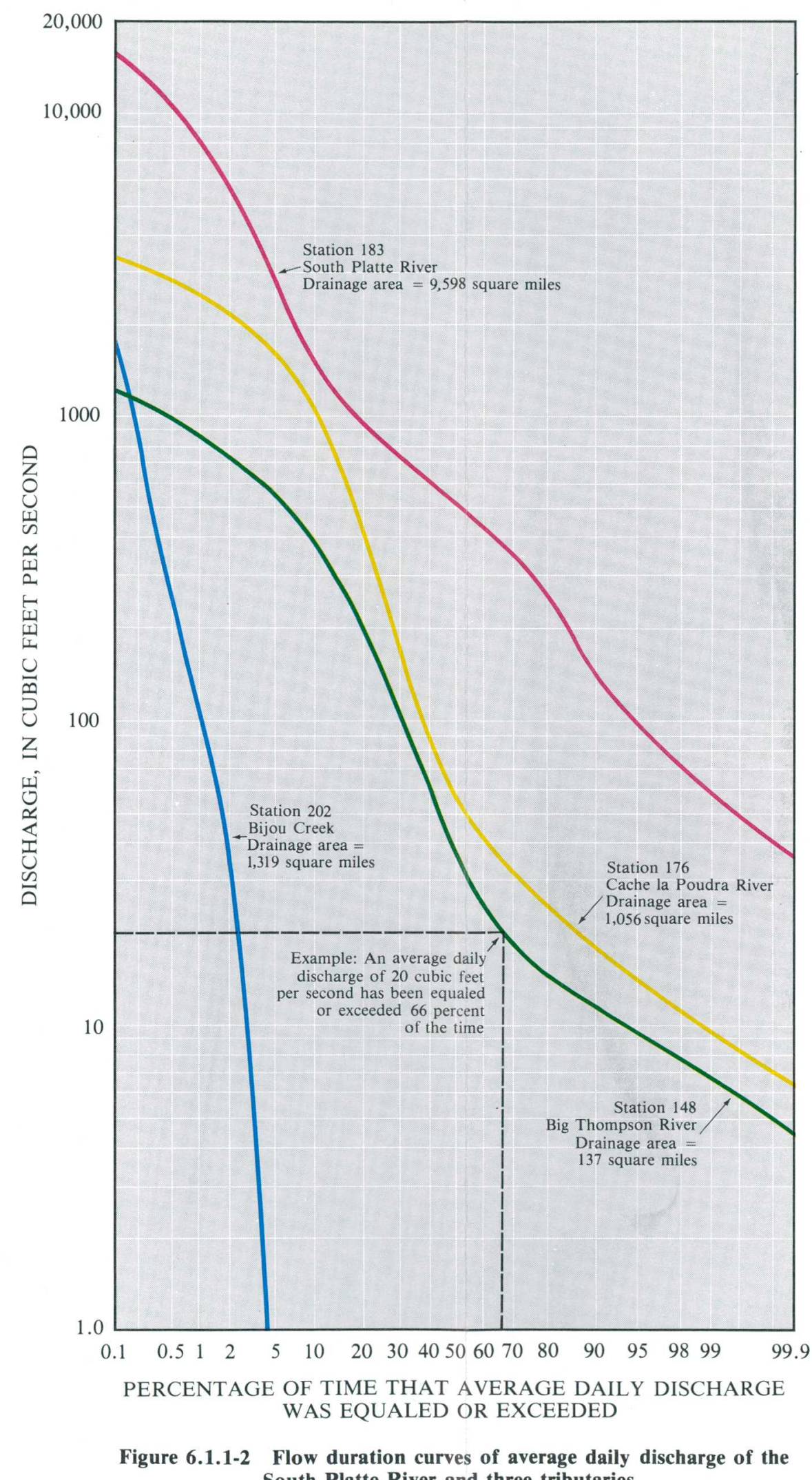

Flow duration curves of average daily
South Platte River and three tributaries.

6.0 SURFACE-WATER QUANTITY

6.1 Streamflow Variability

6.1.1 Flow Duration 


\title{
6.0 SURFACE-WATER QUANTITY--Continued \\ 6.1 Streamflow Variability--Continued \\ 6.1.2 High-Flow Frequency
}

\section{Ephemeral and Perennial Streams Exhibit Different High-Flow Frequency Characteristics}

\author{
High flows on ephemeral streams are much more variable \\ than high flows on perennial streams in Area 59.
}

High-flow frequency curves indicate the average intervals in years between flows equal to or larger than specified magnitudes. In this section the flows specified are the highest average discharges occurring for 1 day, and for 30 consecutive days, of each water year. Highflow frequency information is required in the design of reservoirs and flood-control works, and it is useful in water-resources planning.

High flows on ephemeral streams in the plains generally are the result of summer thunderstorms; because the intensity of these storms can vary greatly, the magnitude of the high flows resulting from thunderstorms also can vary greatly from year to year. High flows on perennial streams in the mountains, on the other hand, tend to be less variable, because they result primarily from snowmelt during late spring and early summer. Frequency curves for 1-day and 30-day average high-flows for a station on Bijou Creek, an ephemeral stream, and for a station on each of three perennial streams, the Big Thompson, Cache la Poudre, and South Platte Rivers (fig. 6.1.2-1) are shown in figure 6.1.2-2.

The variability of high flows on ephemeral streams is apparent from the frequency curves for station $202 \mathrm{Bi}$ jou Creek near Wiggins, Colo. (fig. 6.1.2-2). Steepness of the curves indicates that Bijou Creek generally has a much wider range of high flows over a given range of recurrence intervals than the perennial streams do. In addition, the 1- and 30-day average curves are widely spaced, indicating a wide range in the short-term and long-term average high flows. The average 1-day, and 30-day high flows determined from figure 6.1.2-2 should be considered only as approximate, because the curves for the Bijou Creek station are based on only 6 years of record.

The frequency curves for stations $148 \mathrm{Big}$ Thompson River at Estes Park, Colo., and 176 Cache la Poudre River at mouth of canyon near Fort Collins, Colo., are similar in shape and in spacing between the 1-day and 30-day high flows. The primary difference between the curves for the two stations is the magnitude of the respective high flows for a given recurrence interval. This difference is largely attributable to the differences in drainage area between the two stations. However, the spacing between 1-day and 30-day average high-flow frequency curves is much narrower for these perennial mountain streams, than the spacing for station 202; high flows resulting from snowmelt generally are larger for a longer period of time than high flows resulting from rainfall.

One-day and 30-day high flows at station 183 South Platte River near Kersey, Colo., are much larger than high flows from the other two perennial streams, primarily due to the much larger drainage area. The overall slopes of the curves for this station are considerably different from those for the other two perennial streams, and they also are spaced apart somewhat more. The primary reasons for this probably are: (1) The presence of tributary streams, such as Plum Creek, on the South Platte River upstream from station 183 which have high-flow characteristics similar to Bijou Creek; and (2) the modification of the natural streamflow regime by diversion and regulation (also see section 6.1.1) probably is a factor, since these streamflow modifications are more pronounced over a 30-day period than during a 1-day period. 


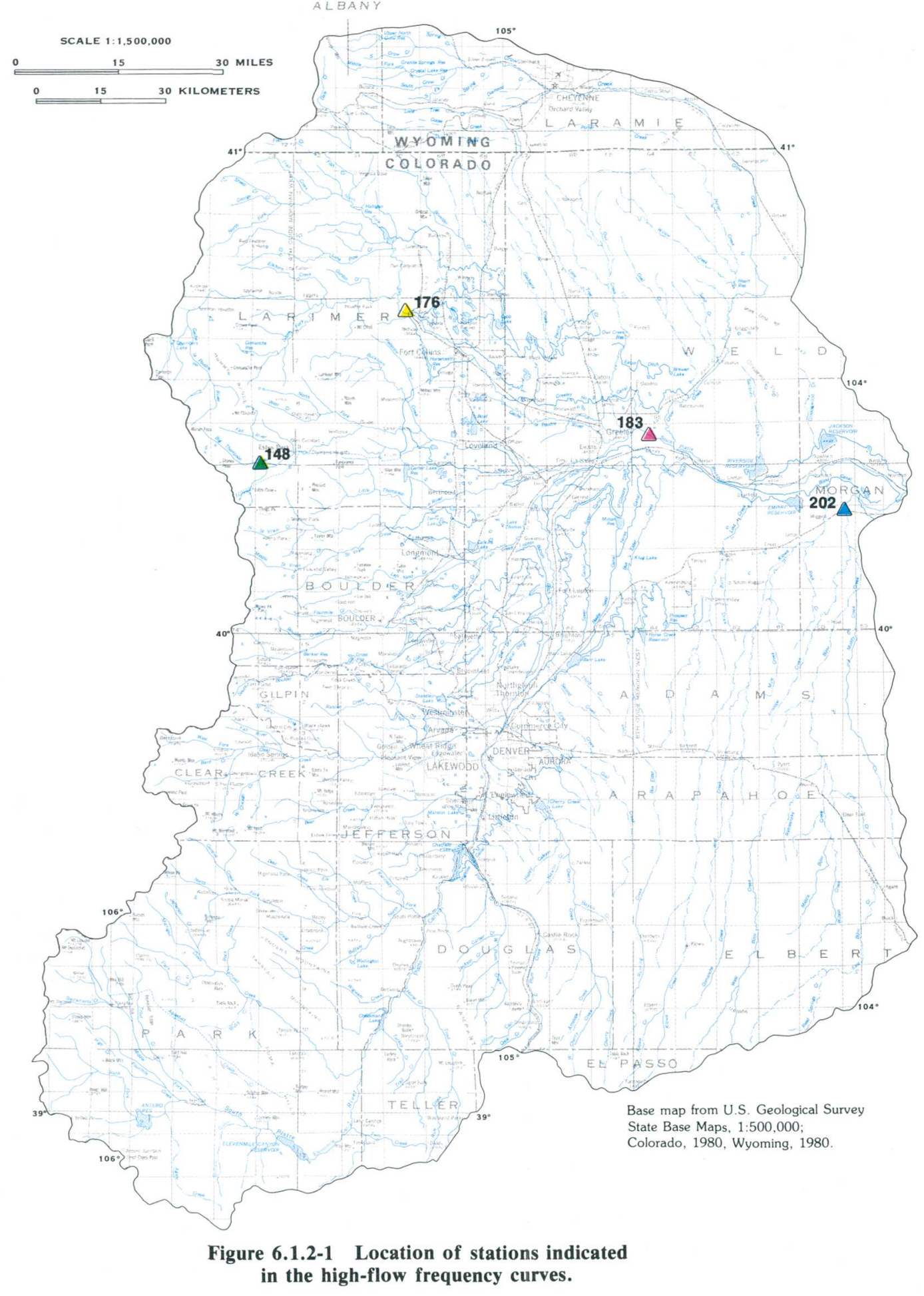

PROBABILITY THAT AVERAGE DISCHARGE WILL BE EQUALED OR EXCEEDED


Figure 6.1.2-2 High-flow frequency curves of 1-day and 30-day average discharge
of the South Platte River and three tributaries. 


\title{
6.0 SURFACE-WATER QUANTITY--Continued \\ 6.1 Streamflow Variability--Continued \\ 6.1.3 Low-Flow Frequency
}

\section{Low-Flow Characteristics of Perennial and Ephemeral Streams Differ Greatly}

\author{
Low flows on perennial streams are sustained primarily by ground-water \\ discharge; ephemeral streams have extended periods of no flow.
}

Low-flow frequency curves indicate the average intervals in years between flows smaller than specified magnitudes. In this section, the flows specified are the smallest average discharges occurring for 7 and 30 consecutive days of each climatic year. Low-flow frequency information is required to evaluate a stream's adequacy as a water supply or as an indication of its wastedilution capacity. A low-flow statistic often used in waste-water discharge permits is the 7-day, 10-year low flow.

Low flows on perennial streams are sustained primarily by ground-water discharge, although gradual melting of perennial snowfields, reservoir releases, and transmountain diversions also augment low flows. Low flow frequency curves for 7-day and 30-day average discharges for a station on each of three perennial streams, the Big Thompson, Cache la Poudre, and South Platte Rivers (fig. 6.1.3-1) are shown in figure 6.1.3-2.

Ephemeral streams have extended periods of no flow and cannot be meaningfully analyzed for low-flow frequency. Thus, curves for ephemeral $\mathrm{Bi}$ jou Creek (station 202) are not presented. For each of the six years of record at station 202, at least 183 consecutive days of no flow were recorded.

Generally, the curves for all three stations are similar in shape. The primary difference is the magnitude of the low flows, which increase with increasing drainage area. The curves for station 148 Big Thompson River at Estes Park, Colo., in particular, are very closely spaced, so no great difference occurs between the 30-day and 7-day low flows. This indicates that low flows at this station are very well-sustained by: (1) Ground-water discharge from alluvium in the stream valleys upstream from the station, (2) annual precipitation quantities sufficient to recharge the alluvium, and (3) minor amounts of runoff from late summer melt of perennial snowfields.

The basins upstream from station 176 , Cache la Poudre River at mouth of canyon near Fort Collins, Colo., and station 183, South Platte River near Kersey, Colo., are much larger, and have much more widely varied hydrologic characteristics than the basin upstream from station 148. These hydrologic varations and lack of homogeneity, in part, account for the greater spacing between the 7-day and 30-day low-flow frequency curves for stations 176 and 183. However, the relative lack of steepness in the curves for these two stations, and also for station 148, especially at the lower ends, also is an indication that low flow generally is wellsustained in the basins upstream from these three stations. 


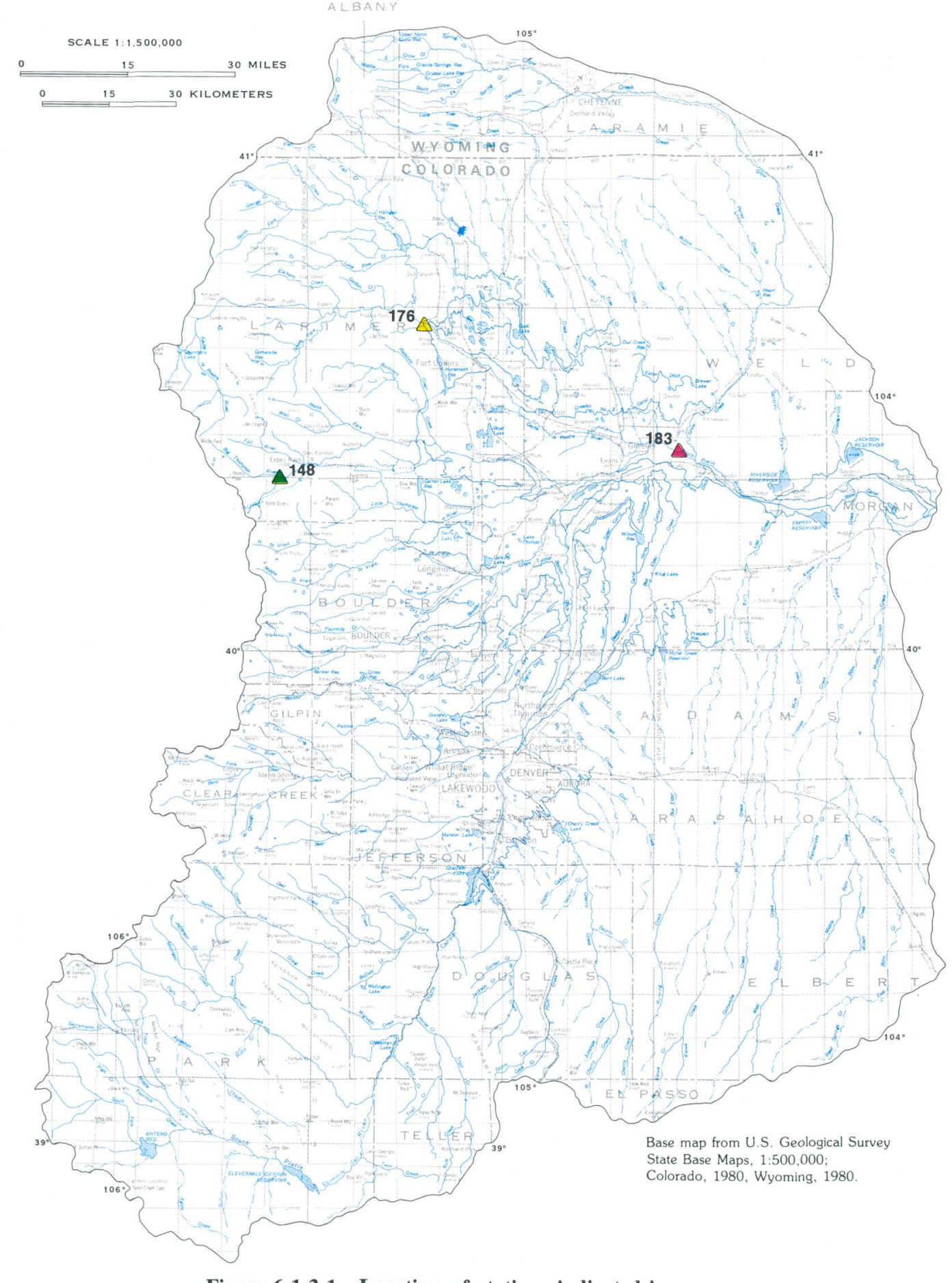

PROBABILITY THAT AVERAGE DISCHARGE WILL NOT BE EQUALED OR EXCEEDED

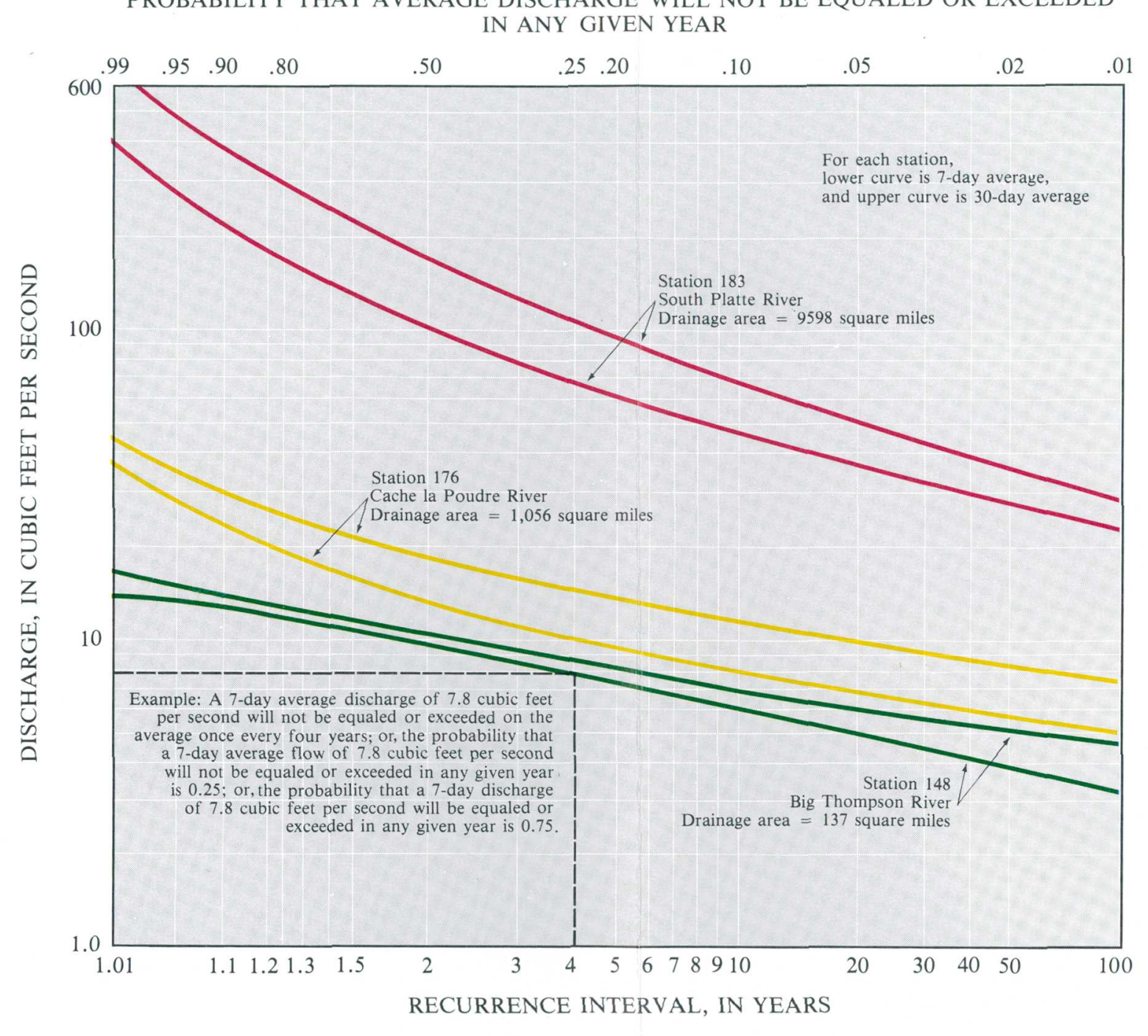

Figure 6.1.3-2 Low-flow frequency curves of 7-day and 30-day average discharges
of the South Platte River and two tributaries.

Figure 6.1.3-1 Location of stations indicated in 


\title{
6.0 SURFACE-WATER QUANTITY--Continued 6.2 Average Annual Flow
}

\section{Average Annual Flow can be Estimated}

\author{
Average annual flow can be estimated at ungaged sites \\ using predictive equations developed for Colorado and Wyoming.
}

Predictive equations are available to estimate average annual flow $\left(Q_{a}\right)$, in cubic feet per second, at ungaged sites in Area 59. Livingston (1970) presents several relations for estimating average annual flow in the mountainous area of Colorado using different combinations of variables. A four-variable relation containing all variables determined to be significant (at the 5 percent level) is:

$$
Q_{a}=0.00140 A^{0.956} S_{t}^{0.192} p^{2.101} t_{i}^{-0.189},
$$

where $A$ is drainage area, in square miles; $S_{t}$ is area of lakes and ponds, as a percentage of drainage area (plus 1 percent); $p$ is average annual precipitation, in inches; and $t_{i}$ is average minimum January temperature in degrees $\mathrm{F}$ (plus $11^{\circ}$ ). This relation, which has a standard error of estimate of 47 percent, was developed by using data from natural-flow streams and is applicable to mountainous basins having average basin altitudes of 7,500 feet or more and with drainage areas of about 1,450 square miles or less (fig. 6.2-1). A relation was not developed for the plains region of Colorado, because only a few suitable streamflow stations were available for analysis (Livingston, 1970 , p. 24).

Lowham (1976) developed average annual flow relations for Wyoming streams and was able to define regions reflecting the primary source of streamflow. Parts of Wyoming region 3, consisting of plains prone to thunderstorm runoff and region 4 , consisting of subdued mountains subject to rainfall and snowmelt runoff, are included in Area 59 (fig. 6.2-1). The boundary between the two regions coincides with an altitude of about 7,500 feet. The relations for both Wyoming regions are defined using drainage area in square miles as the single variable.

The relation for region 3 is:

$$
Q_{a}=0.518 A^{0.53}
$$

this relation applies to only intermittent and ephemeral streams. The relation for region 4 is:

$$
Q_{a}=0.162 A^{0.98}
$$

this relation is applicable only to perennial streams. Because these relations were developed from a very limited amount of data, estimates of the average annual flow from them should be considered to be very approximate (Lowham, 1976, p. 3).

The average annual flow relations developed from Wyoming data are not applicable in Colorado and vice versa; because, in general, the regions for which the relations were developed in the two States are dissimilar. Because average annual flow relations have not been defined for any natural-flow intermittent or ephemeral streams in the plains part of Area 59 in Colorado, the Wyoming region 3 (plains) relation cannot be tested in Colorado. The relation for region 4 in Wyoming was developed from data for stations in subdued mountain areas; the relation for Colorado mountains was developed from data for stations located generally in foothills to high mountain environments.

Application of Lowham's (1976) Wyoming region 4 relation to stations within the northern mountainous region of Colorado used in Livingston's (1970) analysis gives estimates of average annual flow several times less than the average annual flow derived from station records. In applying the relations for "mountain" areas in Area 59, especially on a drainage basin crossing the Colorado-Wyoming boundary, a weighting procedure should be used as follows:

1. Determine the average annual flow for the entire basin using the relations for both Colorado and Wyoming;

2. Weight the discharge determined for each State by the percent of the drainage area in that State;

3. Sum the weighted values to obtain a weighted average annual flow.

However, because of the divergence of the estimates from the two relations, the resulting estimate should be considered to be only very approximate. 


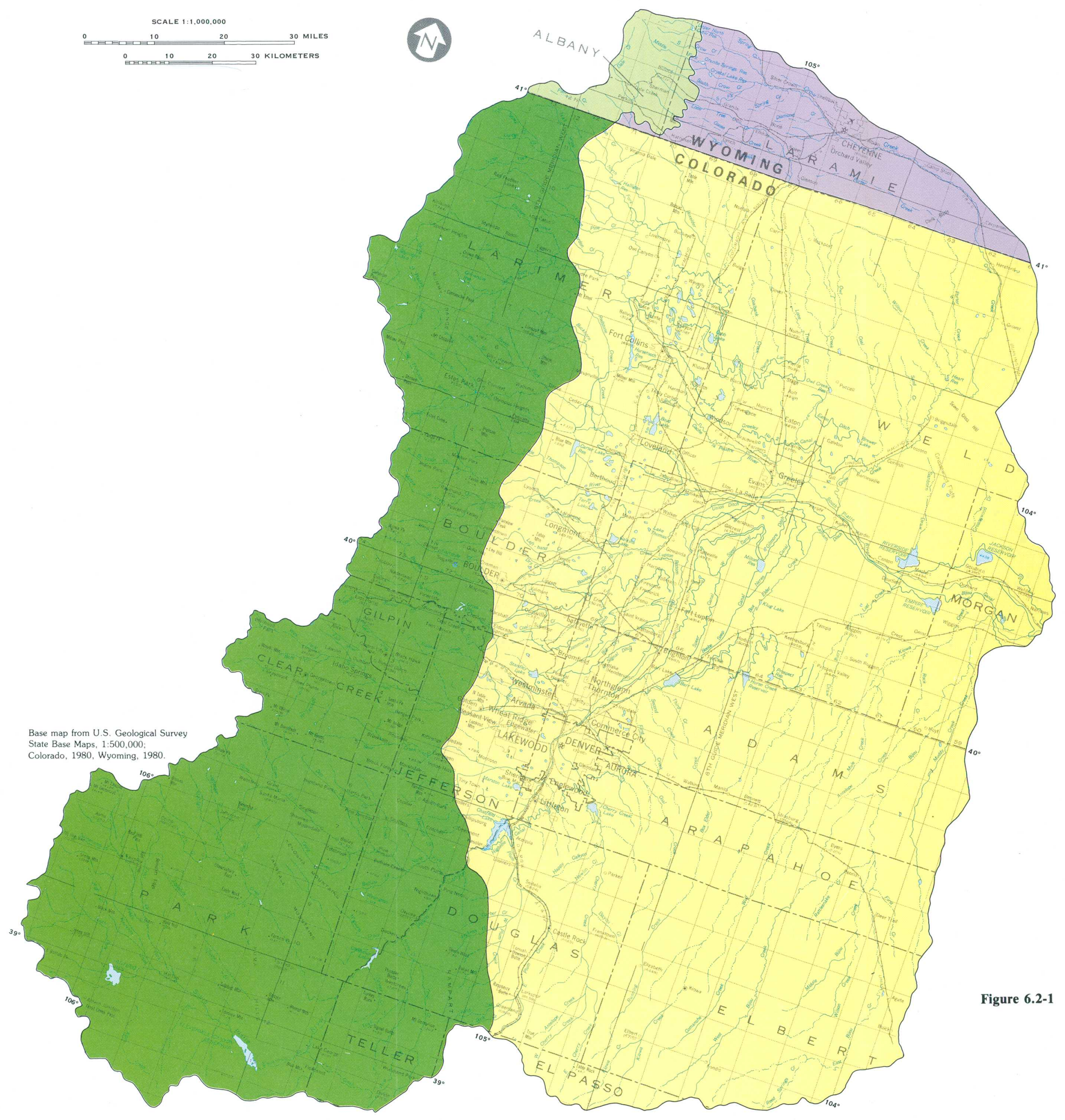

\section{EXPLANATION}

WYOMING REGION 3 (PLAINS)

$\mathbf{Q}_{\mathrm{a}}=\mathbf{0 . 5 1 8 \mathrm { A } ^ { 0 }}$

WYOMING REGION 4 (SUBDUED MOUNTAINS)

$Q=0.162 A^{0.98}$

COLORADO MOUNTAINOUS AREA

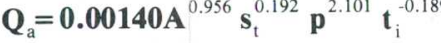

(SEE TEXT FOR EXPLANATION OF FORMULAS)

PLAINS REGION-No relationship developed

because of inadequate data

1re 6.2-1 Regions used for estimating average annual flow. 


\title{
6.0 SURFACE-WATER QUANTITY--Continued \\ 6.3 Floods \\ 6.3.1 Occurrence
}

\section{Severe Flooding Occasionally Occurs in Area 59}

\author{
Flooding in Area 59 which can be severe occasionally results \\ from both snowmelt and thunderstorm runoff
}

\begin{abstract}
Streams in the mountains usually flood annually as a result of snowmelt in late spring and early summer. These primarily perennial streams are the major source of streamflow in the study area. In comparison, streams in the plains flood only occasionally, during summer, in response to locally intense, short-term thunderstorms. Streamflow produced by these primarily ephemeral streams is only a fraction of streamflow produced by perennial streams. Occasionally, however, intense thunderstorms in the mountains can produce severe flooding, such as the flooding of the Big Thompson River on July 31 and August 1, 1976. Runoff resulting from intense rainfall in the up. per parts of the Big Thompson River basin produced a maximum discharge of 31,200 cubic feet per second at station 154 Big Thompson River at
\end{abstract}

mouth of canyon, near Drake, Colo. (fig. 5.0-1). This discharge was more than four times larger than the previously observed peak of 7,600 cubic feet per second for more than 50 years of record. The 1976 peak originated from an area of approximately 60 square miles within the 320 -square mile basin (Grozier and others, 1976) and is nearly identical to the peak of record, 31,500 cubic feet per second, recorded at the South Platte River near Kersey streamflow-gaging station, which monitors a 9,598-square mile basin.

Aerial and ground views of some of the destruction resulting from the Big Thompson River flood at Drake, Colo., and at Waltonia, Colo., a few miles upstream from Drake are shown in figures 6.3.1-1 and 6.3.1-2. 


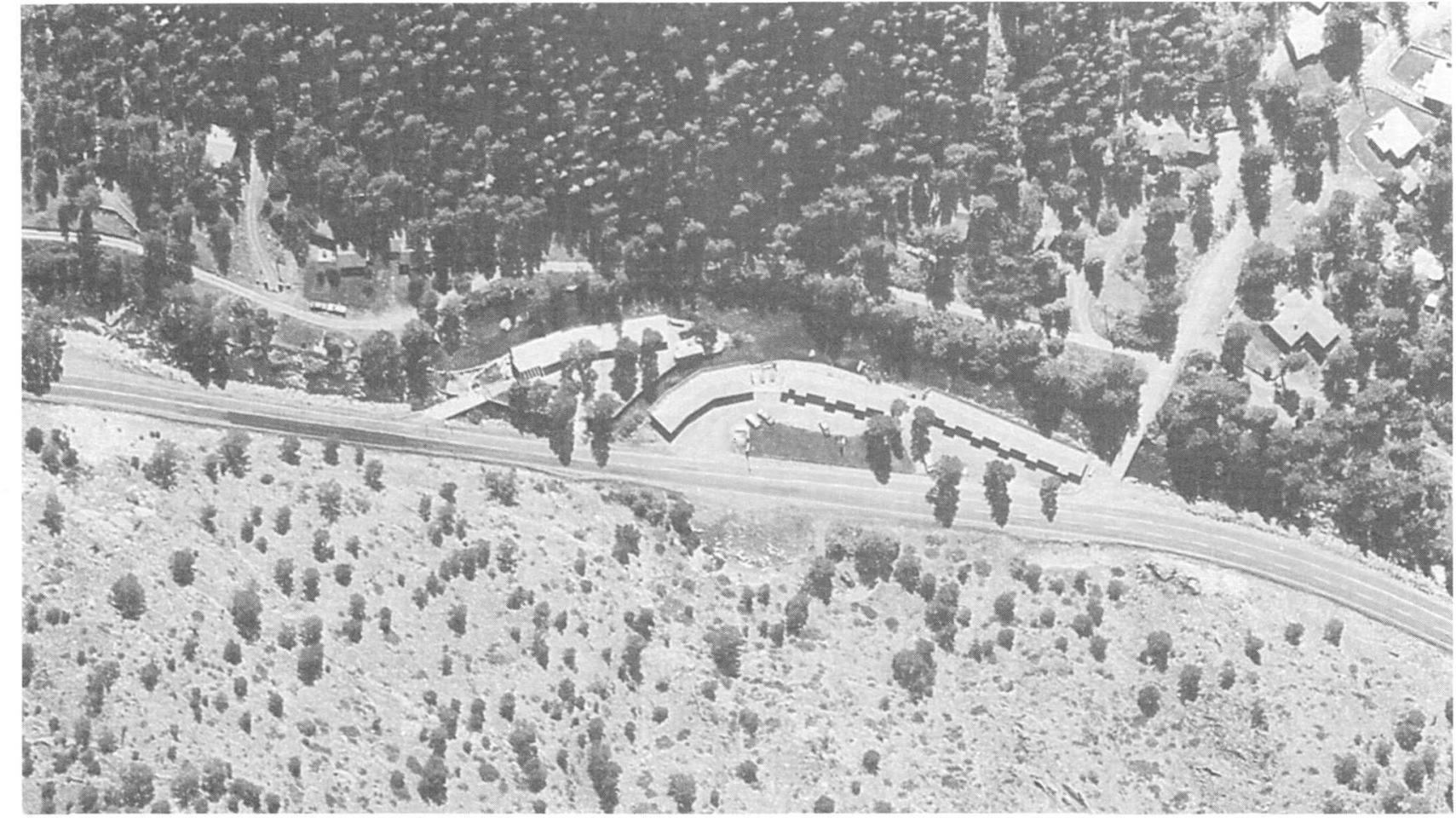
(Before)

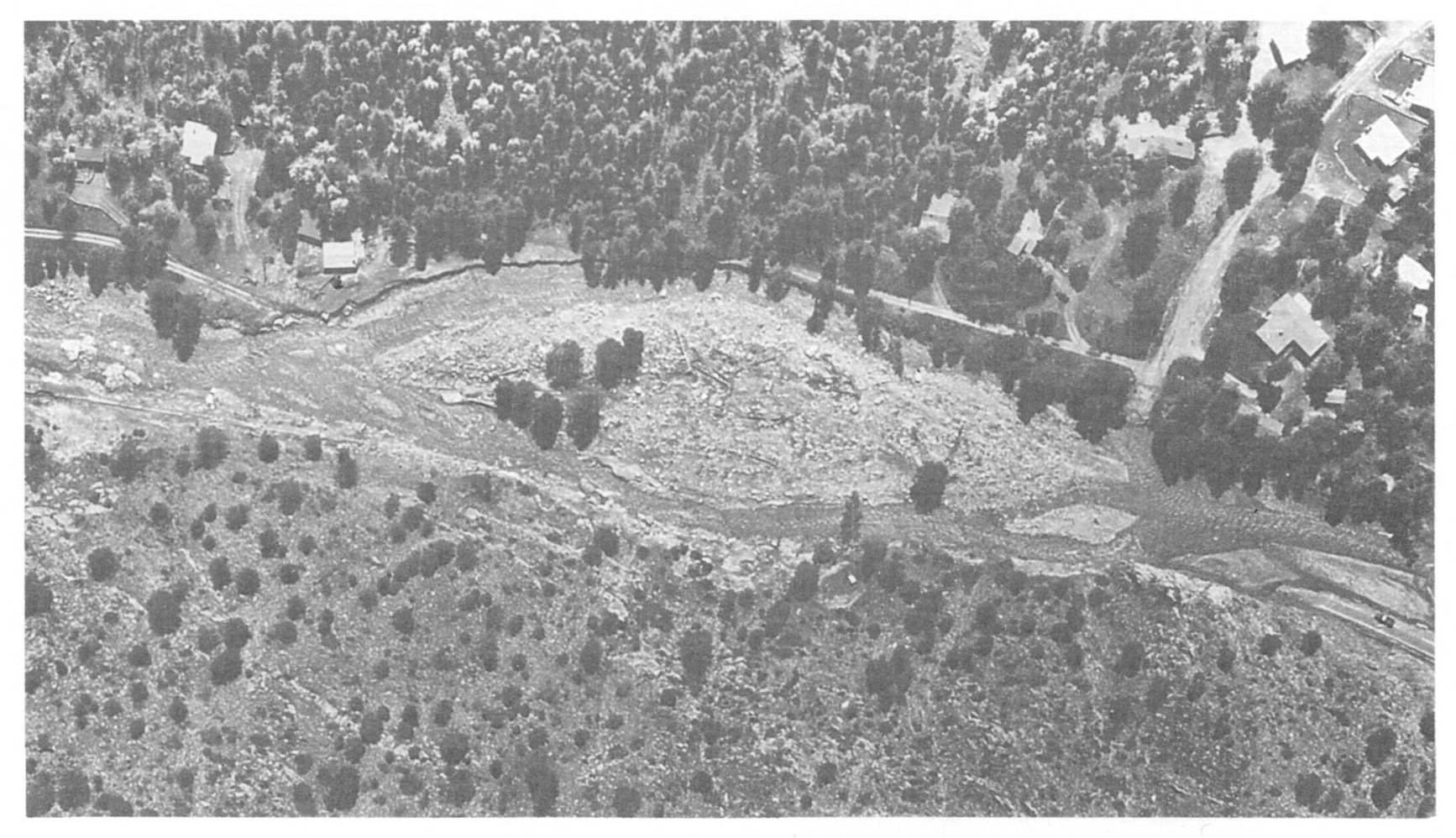

(After)
Figure 6.3.1-1 Aerial photographs taken before and after the 1976 flood of the Big Thompson River, at Waltonia, Colorado. (Courtesy of R and D Aerographics, Loveland, Colorado)
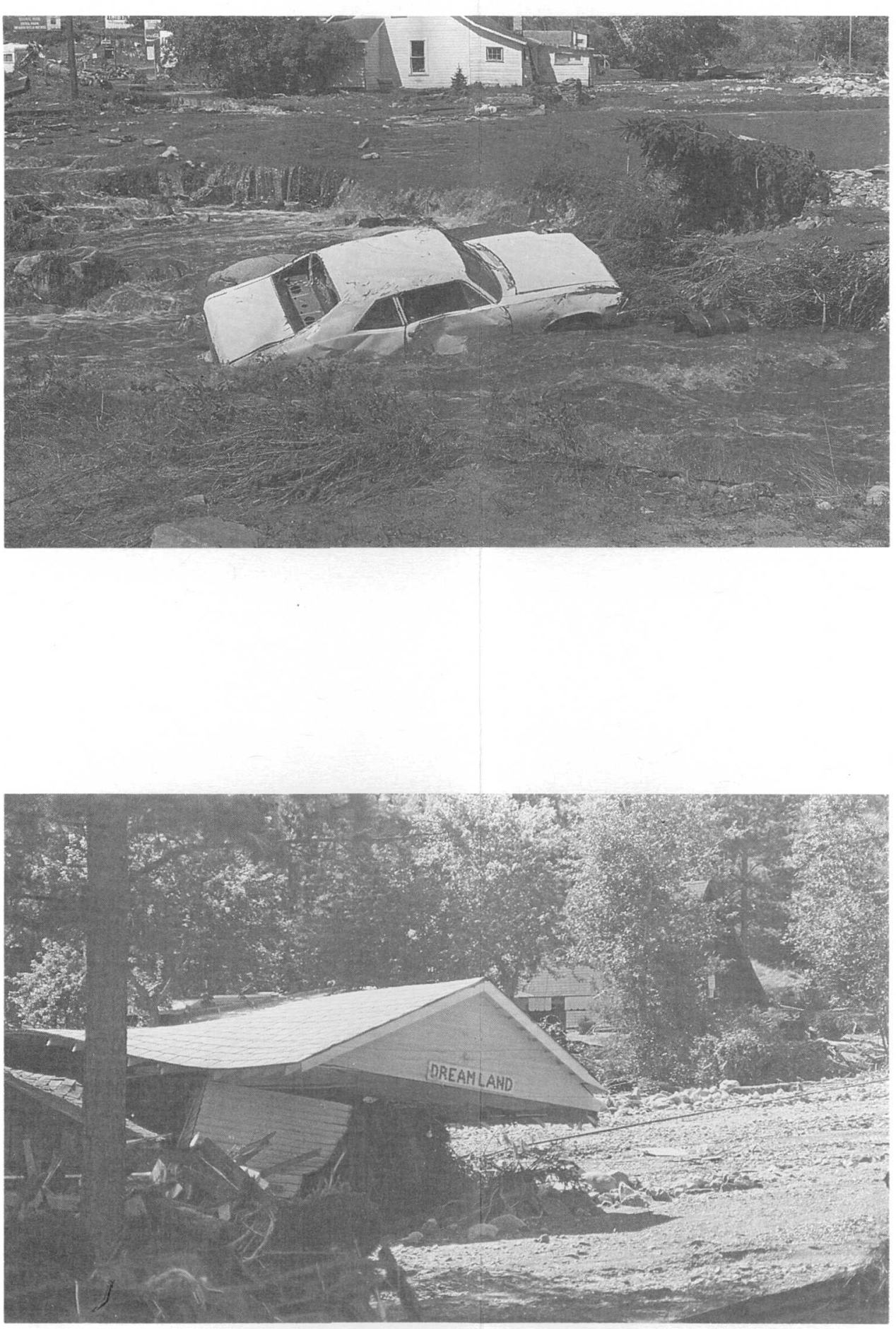
Figure 6.3.1-2 Destruction of homes and vehicles at Drake, Colorado after the 1976 flood

6.0 SURFACE-WATER QUANTITY--Continued 6.3 Floods 


\subsection{SURFACE-WATER QUANTITY--Continued \\ 6.3 Floods--Continued 6.3.2 Frequency}

\section{Flood Flows can be Estimated}

\section{Estimates of the magnitude and frequency of flood peaks can be made on streams in both Colorado and Wyoming.}

Relations for estimating the magnitude and frequency of flood peaks at ungaged sites in Colorado and Wyoming are available. McCain and Jarrett (1976) present relations for estimating 10-, 50-, 100-, and 500-year floods at sites on naturalflow streams in Colorado. A 50-year flood, for example, is expected to be equaled or exceeded, on the average, once in 50 years. Relations are defined for four regions in Colorado, two of which-plains and mountain-are present in Area 59 (fig. 6.3.2-1). The boundary between the two regions coincides with an altitude of 7,500 feet. The relations for the plains region are defined in terms of drainage area, $A$, in square miles, and basin (channel) slope, SB, in feet per mile. The relations for the mountain region are defined in terms of drainage area, $A$, in square miles, and average annual precipitation, $P$, in inches.

In a separate Colorado study, Minges and Livingston (1983) present relations for estimating 2-, 5-, 10-, 25-, 50-, and 100-year floods for rural basins ranging from 0.5 to 15 square miles, which do not experience significant snowmelt flood discharges (below about 8,000 feet altitude). The relations are defined in terms of effective drainage area, $A E$, in square miles, and, for the 2 and 5-year floods, a latitude index, $L I$, in degrees. The relations developed by Minges and Livingston (1983) are recommended in preference to the relations previously developed by McCain and Jarrett (1976) for estimating flood characteristics on small ungaged basins in the eastern plains region of Colorado (fig. 6.3.2-1).

In Wyoming, separate studies to define the magnitude and frequency of floods were completed by Lowham (1976) for drainage basins larger than 11 square miles, and by Craig and Rankl (1978) for drainage basins of less than 11 square miles. The study by Craig and Rankl (1978) excluded mountainous areas. The relations presented by Lowham (1976) are defined for regions reflecting primary sources of streamflow. Wyoming region 3, consisting of plains prone to thunderstorm runoff, and region 4 , consisting of subdued mountains subject to rainfall and snowmelt runoff, are present in Area 59 (fig. 6.3.2-1). The relations are applicable to both perennial and ephemeral streams and provide estimates for the 2-, 5-, 10-, 25-, and 100-year floods. The relations for both regions are defined in terms of drainage area, $A$, in square miles.

The relations presented by Craig and Rankl (1978) are for small, usually ephemeral streams in the plains and valley areas of Wyoming (fig. 6.3.2-1); there relations provide estimates for $2-, 5-, 10-, 25-, 50-$, and 100-year floods. The relations are defined in terms of drainage area, $A$, in square miles; basin slope, $S_{B}$, in feet per mile; maximum relief, $R_{M}$, in feet; and mainchannel slope, $S_{10 / 85}$, in feet per mile.

Equations for the 100-year flood $\left(Q_{100}\right)$ for the various floodfrequency regions in Colorado and Wyoming are shown graphically on figure 6.3.2-2. Approximate ranges in basin size for which the various relations are applicable are indicated by the length of the line on the respective graphs.

The relations presented by McCain and Jarrett (1976) for Colorado plains estimate flood peaks that are two to three times larger than those estimated by the relations presented by Lowham (1976) for Wyoming region 3 (plains). Also, the relations presented by Lowham (1976) for Wyoming region 4 (subdued mountains) predict flood peaks that are several times larger than those predicted by the relations presented by McCain and Jarrett (1976) for Colorado mountains. Although the boundaries between the plains and mountain regions in the two studies coincide with an altitude of 7,500 feet in the vicinity of the State boundary, Wyoming region 4 cannot be considered comparable to the single mountain region in Colorado because Lowham (1976) includes higher mountain areas in Wyoming in a separate region. The relations presented by Minges and Livingston (1983) for small basins in the plains region of Colorado estimate flood peaks that are several times larger than those estimated by the relations presented by Craig and Rankl (1978) for small basins in the plains region of Wyoming. These differences may be due, in part, to the use of basins in the Wyoming study that are located in plains and valley areas throughout the State; the Colorado study used basins located only in the eastern plains region of that State.

The differences between the Colorado and Wyoming flood estimates also may be attributed in part to dissimilarities in regions and to physiographic and climatic differences between the two States. Relations developed using data from a widespread area within a State tend to integrate, or lump, physiographic and climatic differences, and thus provide an "average" relation for the area. Analyses for the respective plains and mountain regions in both Colorado and Wyoming used data from stations ranging from near the southern to near the northern State boundaries, and hence provide average relations for regions extending over 250 miles north to south in each State.

In applying these relations within Area 59, especially on a drainage basin crossing the Colorado-Wyoming boundary, the user may use a weighting procedure as follows:

1. Determine the selected flood discharge for the entire basin using the relations for both Colorado and Wyoming;

2. Weight the discharge determined for each State by the percent of the drainage area in that State;

3. Sum the weighted values to obtain a weighted flood discharge. 



IN SQUARE MILES

${ }^{1}$ Average variable value for all basins used in regression analysis.
(See explanation of equations in text)

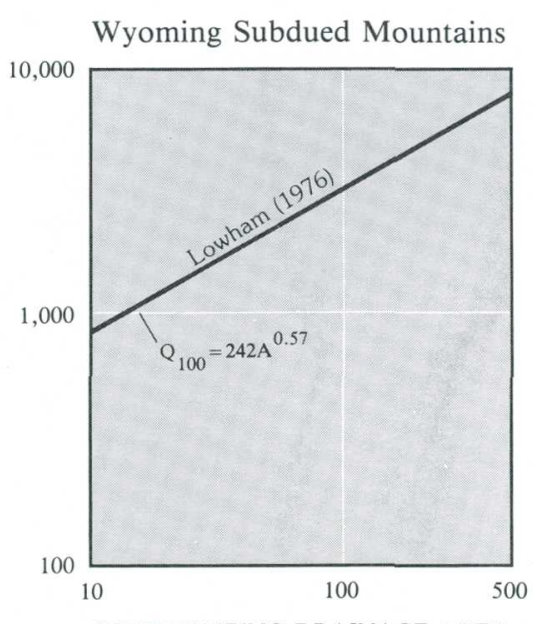

CONTRIBUTING DRAINAGE AR IN SQUARE MILES

Figure 6.3.2-2 Relation between contributing drainage area and the 100-year flood. 


\title{
6.0 SURFACE-WATER QUANTITY--Continued 6.3 Floods--Continued 6.3.3 Hydrographs
}

\section{Durations of Hydrographs Resulting from Snowmelt and From Rainfall are Markedly Different}

\author{
The duration of snowmelt-flood hydrographs is usually measured in weeks or months; the \\ duration of thunderstorm-flood hydrographs is usually measured in hours or days.
}

The magnitude and duration of snowmelt-flood hydrographs for mountain streams depends primarily on drainage area, depth and water content of the snowpack, and air temperature, which is generally inversely related to altitude. Flood hydrographs for stations (fig. 6.3.3-1) on three perennial streams, on the Big Thompson River, the Cache la Poudre River, and the South Platte Rivers are presented in figure 6.3.3-2. These hydrographs illustrate the effect of drainage area and climate on snowmelt flood flows during the spring and early summer of 1980 , following a winter of above normal snowfall. One hydrograph illustrating a thunderstorm flood in July 1977 on an ephemeral stream, Bijou Creek, also is presented in figure 6.3.3-2.

Station 148 Big Thompson River at Estes Park, Colo. (fig. 6.3.3-2), recorded the smallest flood peak, primarily because it has the smallest drainage area of the three perennial stream stations. The flood peak occurs in late spring and is relatively sharp. Because basin altitude ranges from approximately 7,500 feet at the station to more than 14,000 feet at the divide, snowmelt occurs later in the season.

The flood peak at station 176 Cache la Poudre River at mouth of canyon near Fort Collins, Colo., is more than twice that at the Big Thompson River station, due primarily to a much larger drainage area. The hydrograph, however, does not have a pronounced peak, but, rather, a sustained high flow, commencing about a month prior to the Big Thompson River peak. The extended duration of flood flow at the Cache la Poudre River station results primarily from the greater range in basin altitudes, which range from approximately 5,200 feet at the station to more than 13,000 feet at the basin divide. Low-altitude foothill areas contribute runoff in early spring; high mountain areas contribute runoff in late spring and early summer.

The flood hydrograph for station 183 South Platte River near Kersey, Colo., is a composite of flood hydrographs from tributary basins of varying sizes and altitudes. These basins compare the 9,598-square miles basin upstream from Kersey and provide runoff from plains, foothills, and mountain areas. The flood peak at the South Platte River station is significantly larger than the peak at either the Big Thompson or the Cache la Poudre River stations, again primarily because of a much larger drainage area. However, a direct comparison of the South Platte River hydrograph with the tributary stream hydrographs is not possible, because the South Platte River is substantially affected by upstream storage and irrigation diversions. Without these effects, the peak discharge would probably be larger and occur later in the snowmelt-runoff period. However, the extended duration of the hydrograph resulting from the wide range in basin altitudes, from about 4,600 feet at the station to more than 14,000 feet at the basin divide, is apparent. This large range in altitude encompasses a wide range in hydrologic and climatic conditions.

The duration of thunderstorm-flood hydrographs is generally measured in hours or days. The sharpness of these hydrographs, in comparison to snowmelt hydrographs, is seen at station 203 Bijou Creek near Fort Morgan, Colo. (fig. 6.3.3-2), for the period July $22-30,1977$. Two distinct flood peaks resulting from thunderstorm runoff are apparent during this 8-day period. July $22,24,25,28$, and 29 have average daily discharges of 30 cubic feet per second or less, whereas the intervening flood days of July 23,26 , and 27 have average daily discharges of 180,762 , and 230 cubic feet per second respectively. The instantaneous flood peak on July 27 was 2,200 cubic feet per second, the peak of record for the station.

Flood damage in valleys of streams and rivers results because of industrial, commercial, and residential development on the flood plain. Maps showing areas that have a one-in-ahundred chance, on the average, of being inundated during any year are available for many of the more highly developed parts of Area 59. An index to these "flood-prone area" maps is shown in figure 6.3.3-3. In the densely populated areas of metropolitan Denver and Boulder, Colo., more-detailed flood-hazard mapping has been completed by the Federal Insurance Administration as well as by State and local agencies (Lang and McCain, 1975). In the Cheyenne, Wyo., metropolitan area, detailed flood studies have been completed by the U.S. Army Corps of Engineers. Most of the maps shown in figure 6.3.3-3 were completed prior to 1975 , and the delineated areas may have been affected by continuing urbanization or significantly changed by construction of flood-control projects. Two such projects are Chatfield Lake on the South Platte River near Littleton, Colo. (completed in 1975), and Bear Creek Lake on Bear Creek near Morrison, Colo. (completed in 1979). Copies of flood-prone area maps for the respective States may be obtained from:

Public Inquiries Office

U.S. Geological Survey

1012 Federal Building

1961 Stout Street

Denver, CO 80202

District Office

U.S. Geological Survey

P. O. Box 1125

Cheyenne, WY 82003

In addition to the maps shown in figure 6.3.3-3, Dosch (1982a, 1982b) has mapped flood-prone areas in Elbert County, Colo. These maps are available from:

Elbert County Land Use Administrator

County Courthouse,

P. O. Box 205

Kiowa, CO 80117 


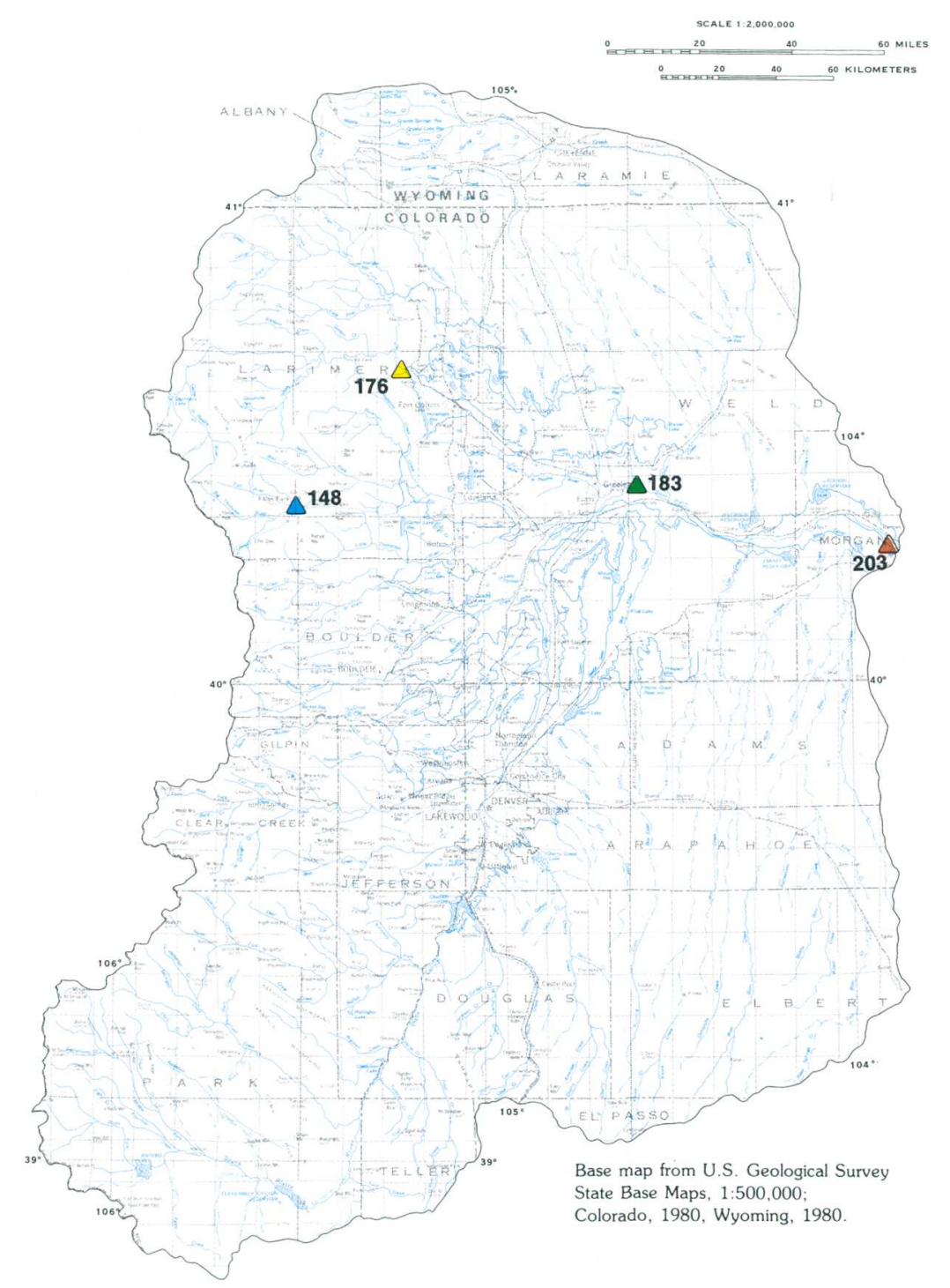

Figure 6.3.3-1 Location of stations indicated in the flood hydrograph

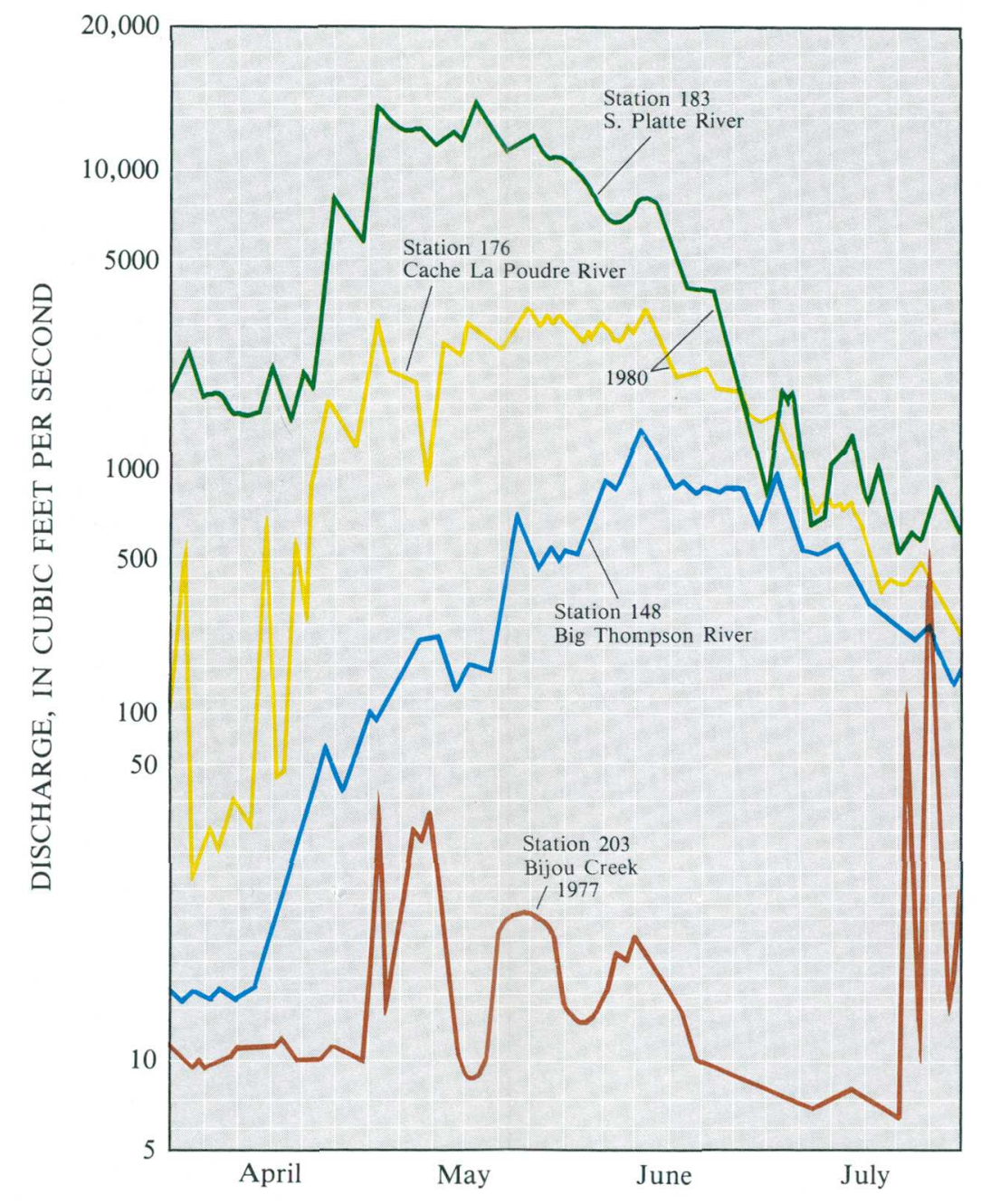

Figure 6.3.3-2 Flood hydrographs for the South Platte River and three tributaries.

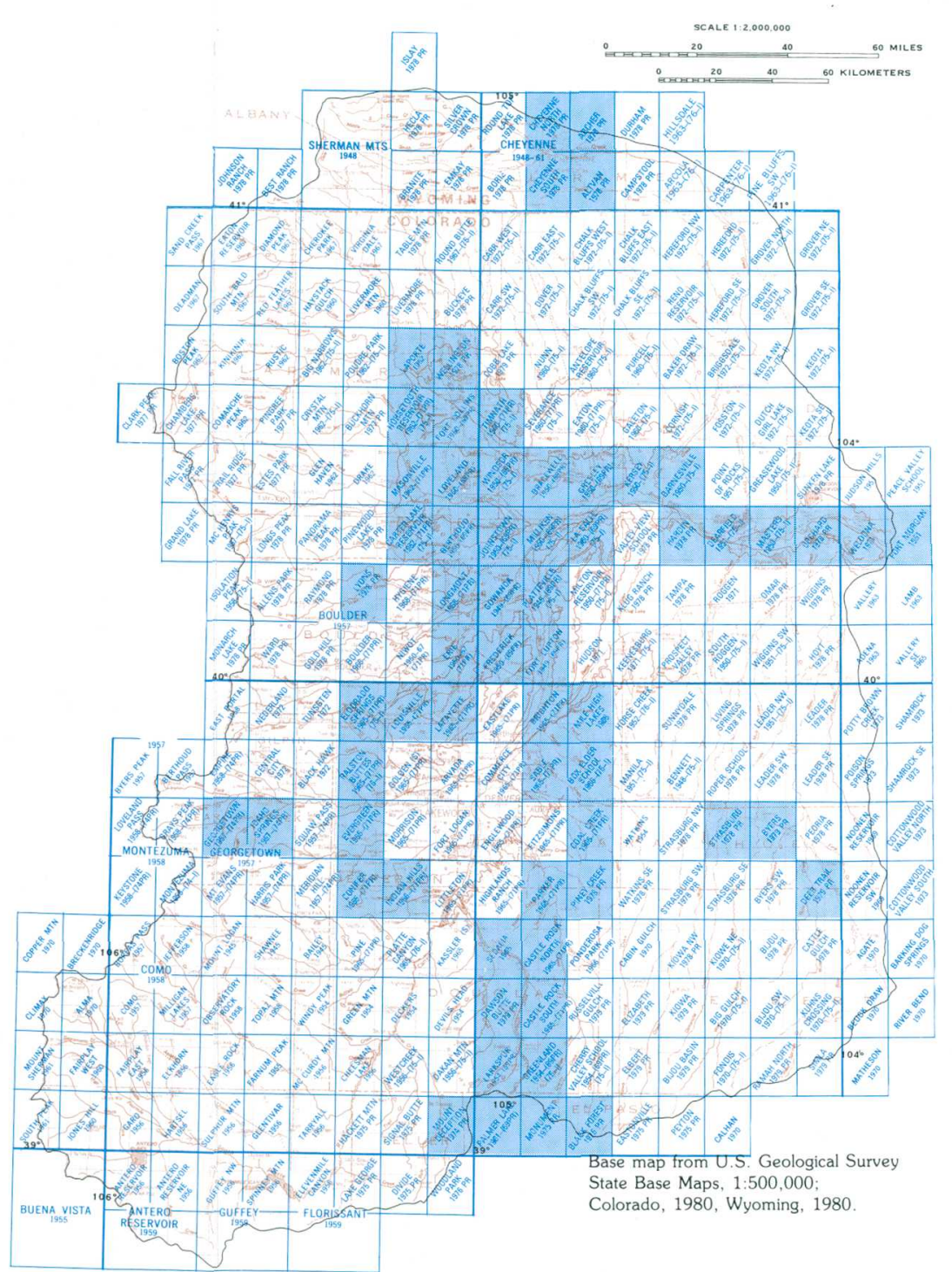

Figure 6.3.3-3 Index of flood-prone area maps and topographic maps. 


\title{
6.0 SURFACE-WATER QUANTITY--Continued \\ 6.4 Streamflow Gain-and-Loss Investigations
}

\section{Gain-and-Loss Investigations Generally Show Gains in Streamflow}

\author{
Streamflow gains within irrigated alluvial valleys of Area 59 result \\ largely from ground-water return flows derived from infiltration \\ of streamflow diverted for irrigation and reservoir storage.
}

Interest in ground-water return flows to streams in Area 59 coincided with the start of surface-water diversions for the irrigation of crops during the last century. Actual measurements of streamflow to quantify these gains began with an investigation done on a reach of the Cache la Poudre River near Greeley, Colo., during October 12-15, 1885 (Carpenter, 1911). The first such investigation on the South Platte River was done in October 1889; it included a reach of the river from the mouth of the canyon near Littleton, Colo., to the Colorado-Nebraska State line. Starting in 1900, gain-and-loss investigations were conducted on most of the other major perennial tributaries to the South Platte River within the eastern plains part of Area 59. Investigations were done annually on many of the streams through 1910. Results of these early investigations are presented by Carpenter (1911). Gain-and-loss investigations were again conducted on the South Platte River from 1916 to 1921, the results of which are presented by Parshall (1922).

More recently, the U.S. Geological Survey conducted gain-and-loss investigations on the South Platte River from station 109 at Henderson, Colo., downstream to Julesburg, Colo. (outside of Area 59), (Hurr and others, 1975). The investigations done in March and November 1968 for the reach within Area 59 are summarized in figure 6.4-1. All subreaches in Area 59 showed gains in streamflow for both the March and November investigations, except the most upstream subreach, which had no gain during the March study. Gains ranged to more than 9 cubic feet per second per mile during the March study to more than 10 cubic feet per second per mile during the November study.

From December 1976 to October 1977, more intensive gain-and-loss investigations were conducted from station 190 South Platte River at Masters, Colo., downstream to the confluence with Bijou Creek. Results of these investigations are presented by Minges (1983).

Other recent gain-and-loss investigations by the U.S. Geological Survey within Area 59 include studies conducted in 1979 on the Middle Fork and main stem of the South Platte River and on Tarryall Creek in South Park, Park County, Colo. (U.S. Geological Survey, 1980). Additional studies include St. Vrain and Left-Hand Creeks (U.S. Geological Survey, 1980), and three studies on reaches of Boulder, Coal, and St. Vrain Creeks (Major and others, 1983). 

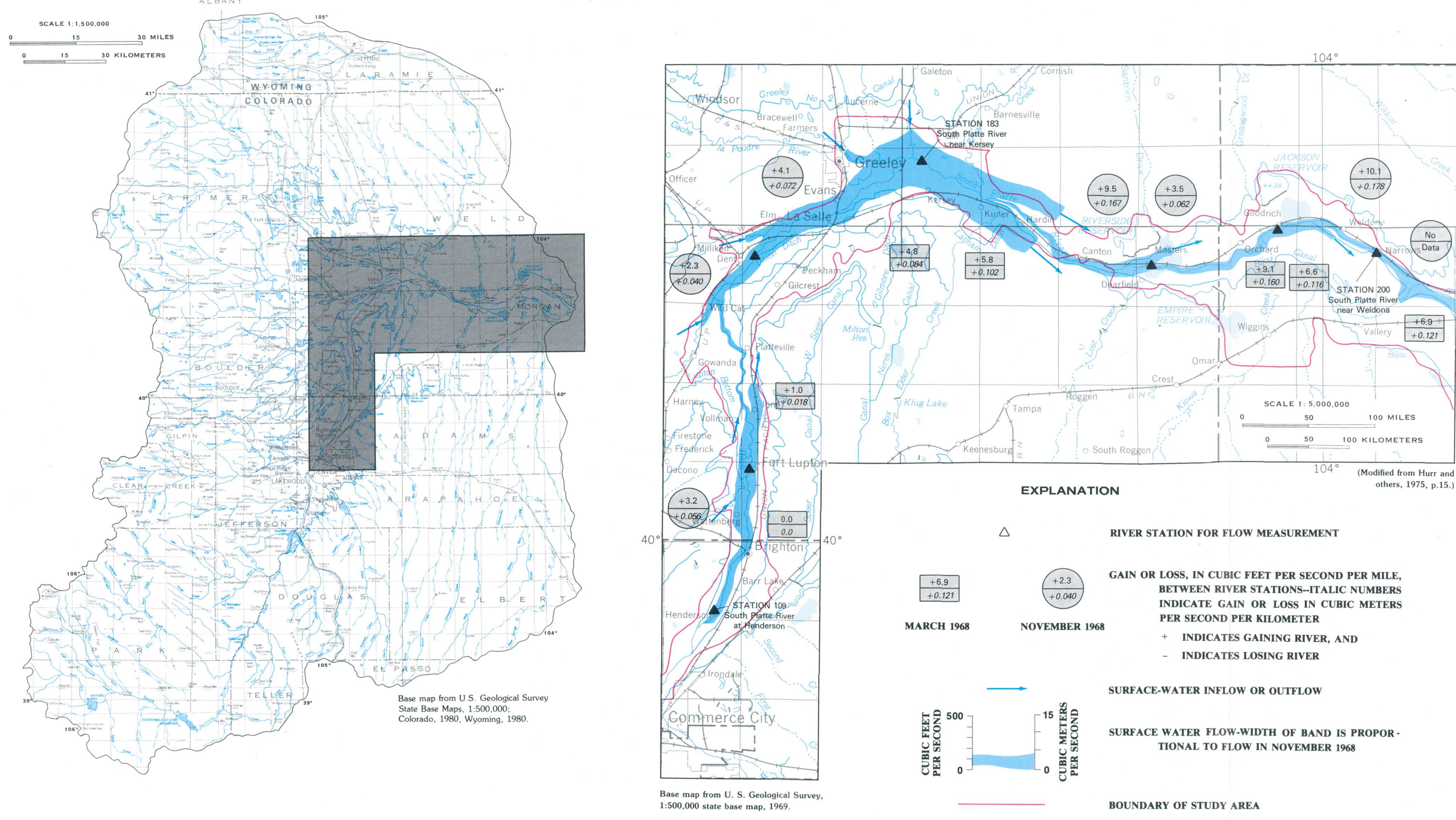

Figure 6.4-1 Streamflow gain and loss of the South Platte River from Henderson to Narrows, Colorado. 


\title{
7.0 SURFACE-WATER QUALITY 7.1 Introduction
}

\section{Water-Quality Information is Important to Assess Impact of Mining on Streams}

\author{
Mining activities can affect stream water quality. Water-quality constituents \\ and properties, including specific conductance, $\mathrm{pH}$, sulfate, and selected \\ dissolved and total recoverable trace-element data from 92 stations \\ were used to assess the water quality of the study area.
}

Knowledge of the water quality of a region has become critical since enactment of the Surface Mining Control and Reclamation Act of 1977. The probable hydrologic consequences of mining and reclamation are required inclusions in permit applications for mining; however, little information is provided on water-quality constituents and properties that should be monitored. Paragraph 779.16 (Office of Surface Mining, 1979) states that, in general, local water-quality standards are applicable, but as a minimum, impact determinations should consider the following: (1) Dissolved solids; (2) suspended solids; (3) acidity; (4) $\mathrm{pH}$; (5) total recoverable and dissolved iron; and (6) total recoverable manganese. Other water-quality properties or constituents that might be affected by surface mining include specific conductance, alkalinity, sulfate, and aluminum.

In general, as surface mining disturbs the landscape, it also results in changes in the hydrologic characteristics of the surrounding areas. Hydrologic changes can affect the amounts of suspended sediment carried by streams and the amounts of dissolved solids and dissolved or total recoverable trace elements in surface water.

Iron sulfides (pyrite and marcasite) commonly occur in coals and associated strata. Once exposed to the atmosphere by mining, these minerals are readily oxidized, producing sulfuric acid and iron hydroxide precipitate. Increased acidity in the water, in turn, results in increased dissolution of additional minerals. Such water draining a mined area generally has $\mathrm{pH}$ values ranging from 2.5 to 5.0 , and large sulfate, trace-element, and dissolved-solids concentrations. The resulting acid-mine drainage is one of the most common water-quality problems associated with coal mining in the Eastern United States, but is largely unknown in western coal mines.

In the study area, the chemical-weathering reaction discussed previously occurs, but the native waters are buffered by carbonate and bicarbonate (alkalinity), normally preventing the occurrence of acid waters and large concentrations of dissolved trace elements. The semiarid climate also aids in preventing the formation of acid water. Overall, some increases in dissolved solids, particularly sulfate, and increases in total recoverable trace-element concentrations are likely as a result of mining. But because the $\mathrm{pH}$ of the water is neutral to basic, and because bicarbonate is abundant, trace elements largely remain in the suspended phase, sorbed to the fine-grained sediment. Increases in total recoverable trace-element concentrations are usually associated with increases in suspended-sediment concentration.

Water-quality data collected from stream stations in the study area were retrieved from the WATSTORE data base com. puter file. Approximately 400 surface-water stations are located in the study area, from which some water-quality information has been previously collected. Of these, 92 stations were chosen for presentation of water-quality data in this report. Stations were chosen, based on the following criteria: (1) Presence of specific-conductance data; (2) number of measurements; and (3) full coverage of the study area. In the following sections, some sites are included that present water-quality information from only one sample, because that was the only information available for that part of the study area.

Of the 92 water-quality stations presented here, 51 were U.S. Geological Survey stations, where water-quality data were previously collected. The oldest period of record at one of these stations is about 25 years; many of the stations have been discontinued. Eighteen permanent-record water-quality streamflow stations are presently operating in the study area. At 80 percent of these stations, major chemical constituents are collected on a monthly basis; and at about 40 percent of these stations, trace elements are collected on a monthly basis. The additional 41 stations presented for the study area are miscellaneous stations, where water-quality information was collected as part of ongoing research projects. Stations used in the analyses are shown in figure 7.1-1; the station numbers correspond to a name, latitude-longitude, and station ID number shown in section 12.1 in the "Supplemental Information" section at the end of the report.

Water-quality constituents and properties for which data were retrieved include specific conductance, $\mathrm{pH}$, sulfate, dissolved and total recoverable arsenic, cadmium, copper, iron, lead, manganese, mercury, selenium, and zinc. The averages (medians for $\mathrm{pH}$ ) and ranges of each constituent or property were determined for each sampling site. A color-coded range of averages and median values for each stream station was plotted on a map for regional comparison. Various symbols were used for station locations, depending on the number of samples collected or measurements made at that station.

In the study area, stream-water quality was best in the mountainous region west of the Front Range, with most stations having low specific conductance and, thus, low dissolvedsolids values. Concentrations increase in the plains, because streams flow through sedimentary basins, because of agricultural effects from irrigation, and because of urbanization. Some mountainous stream stations showed effects of drainage from previous metal-mining areas, with some larger traceelement concentrations and lower $\mathrm{pH}$ values. No stream stations exist where water-quality information has been collected relating to the single active surface-coal mine in the study area. Streams draining abandoned underground coal-mining areas generally have $\mathrm{pH}$ values greater than the overall average for the study area, possibly the result of the use of crushed limestone in past mining activities. Some dissolved trace-element concentrations exceed water-supply standards in and near mining areas; however, these concentrations decrease rapidly downstream. 


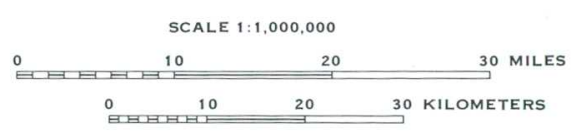

(4)

SAMPLING STATION AND NUMBER
pling stations is listed in section 12.1
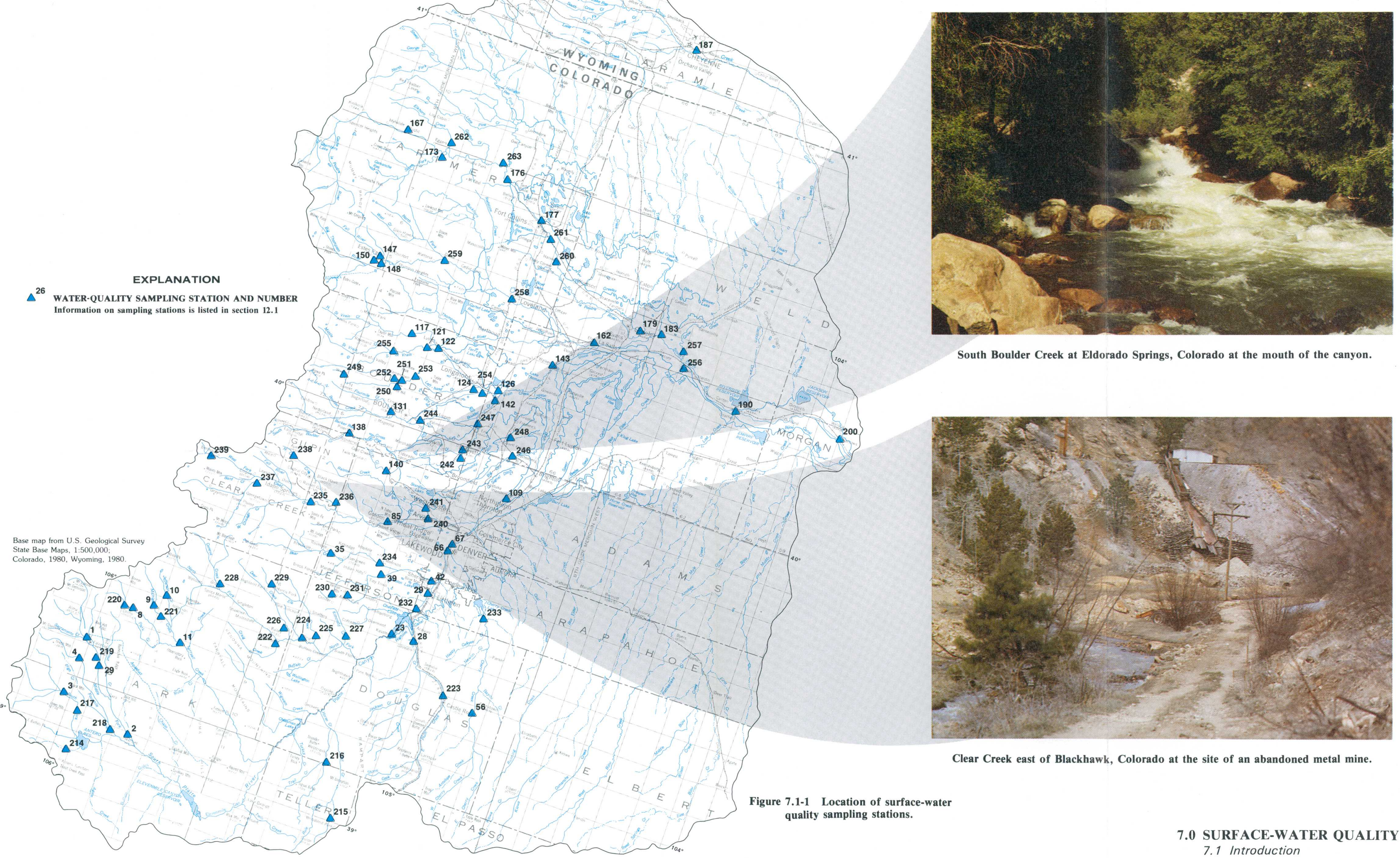

South Boulder Creek at Eldorado Springs, Colorado at the mouth of the canyon.

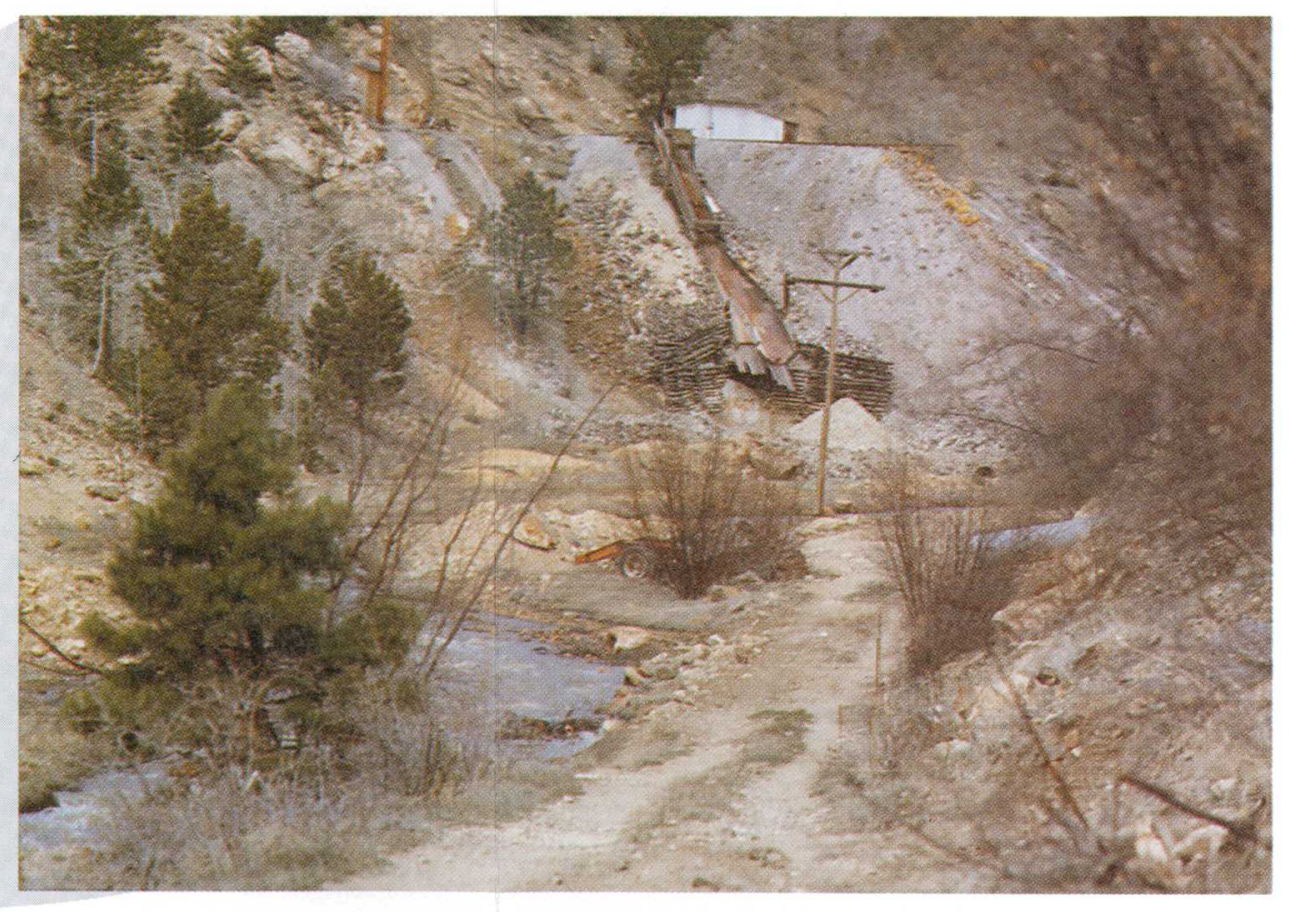

Clear Creek east of Blackhawk, Colorado at the site of an abandoned metal mine. 


\title{
7.0 SURFACE-WATER QUALITY--Continued 7.2 Specific Conductance
}

\section{Regional Water-Quality Trends Indicated by Specific Conductance}

\author{
The lowest specific-conductance values are found in streams at the higher \\ elevations of the Front Range and tend to increase in streams at the \\ lower elevations and to the east of the Front Range.
}

\begin{abstract}
Ranges of average specific-conductance values (see section 2.0 for definition) measured at 83 stations in Area 59 are shown in figure 7.2-1. Statistics of specificconductance measurements for the 83 stations are in section 12.3. A regional trend in specific conductance occurs, with larger values within and east of the Front Range. The average specific conductance for the study area is 838 micromhos, although that value is generally less at higher elevations west of the Front Range. Specific-conductance values measured at stations in the study area ranged from 18 to 24,000 micromhos. Coal Creek (station 140, 243, and 247) and Ralston Creek (station 240), which historically have been associated with coal mining, had an average specific conductance of 814 micromhos, which is near the average for the study area.

Specific conductance normally varies inversely with stream discharge, and generally is larger during low-flow periods, because of prolonged water contact with soluble minerals in soils and rocks, as well as concentration of minerals from ground-water discharge to the stream. During high-flow periods, specific conductance generally is less, because of the shorter contact time with soluble minerals, and because of dilution.
\end{abstract}

Results from statistical models relating specific conductance to dissolved solids for three stations (176, 177, 179) on the Cache la Poudre River are shown in figure 7.2-2. Station 176 has specific-conductance values less than 500 micromhos and would be representative of streams in the study area, draining granitic mountain areas. Streams in the mountains generally have smaller amounts of dissolved solids because solutes are less available in the granitic rock environment, direct snowmelt runoff provides dilution, and the activities of man are minimal.

Station 177 has specific-conductance values ranging to 775 micromhos and would be representative of higherelevation plains streams. The discharge is still derived mostly from snowmelt in the granitic mountains but the ion concentrations have increased relative to station 176. These larger specific conductance values are probably due to the increased availability of soluble minerals in the sedimentary rocks, and because of agricultural effects from irrigation, and urbanization.

Station 179 has specific-conductance values ranging to 2,350 micromhos and would be representative of streams in the plains having a larger proportion of their drainage in sedimentary rock, especially with respect to their headwaters. This site then has a larger supply of solutes available, and consequently the model depicting the relation of specific conductance to dissolved solids (fig. 7.2-2) has a steeper slope than the other two models. The coefficient of determination $\left(\mathrm{r}^{2}\right)$ of this model is the smallest of the three models, but still explains 93 percent of the variation in the dissolved-solids concentrations. The standard error of estimate is also larger for this model mainly because the values show more deviation from the model at the upper end than at the lower end.

The relations shown in figure 7.2-2 can be used to give a reasonable estimate of the dissolved-solids concentration at these sites and similar models can be developed for other sites in the study. The values of dissolved solids from these determinations should not be considered the absolute value, even within the limits of the standard error of estimate (shown in figure 7.2-2). Although the models have a significant degree of correlation $\left(\mathrm{r}^{2}=.94, .98\right.$, and .93 , respectively) between specific conductance and dissolved solids, not every water-quality variable is included in these models. Finally, the determination of dissolved solids by using these models gives no indication of what individual constituents are present in the water or of their relative concentrations. These models can be used as practical tools, but the user should consider their limitations. 


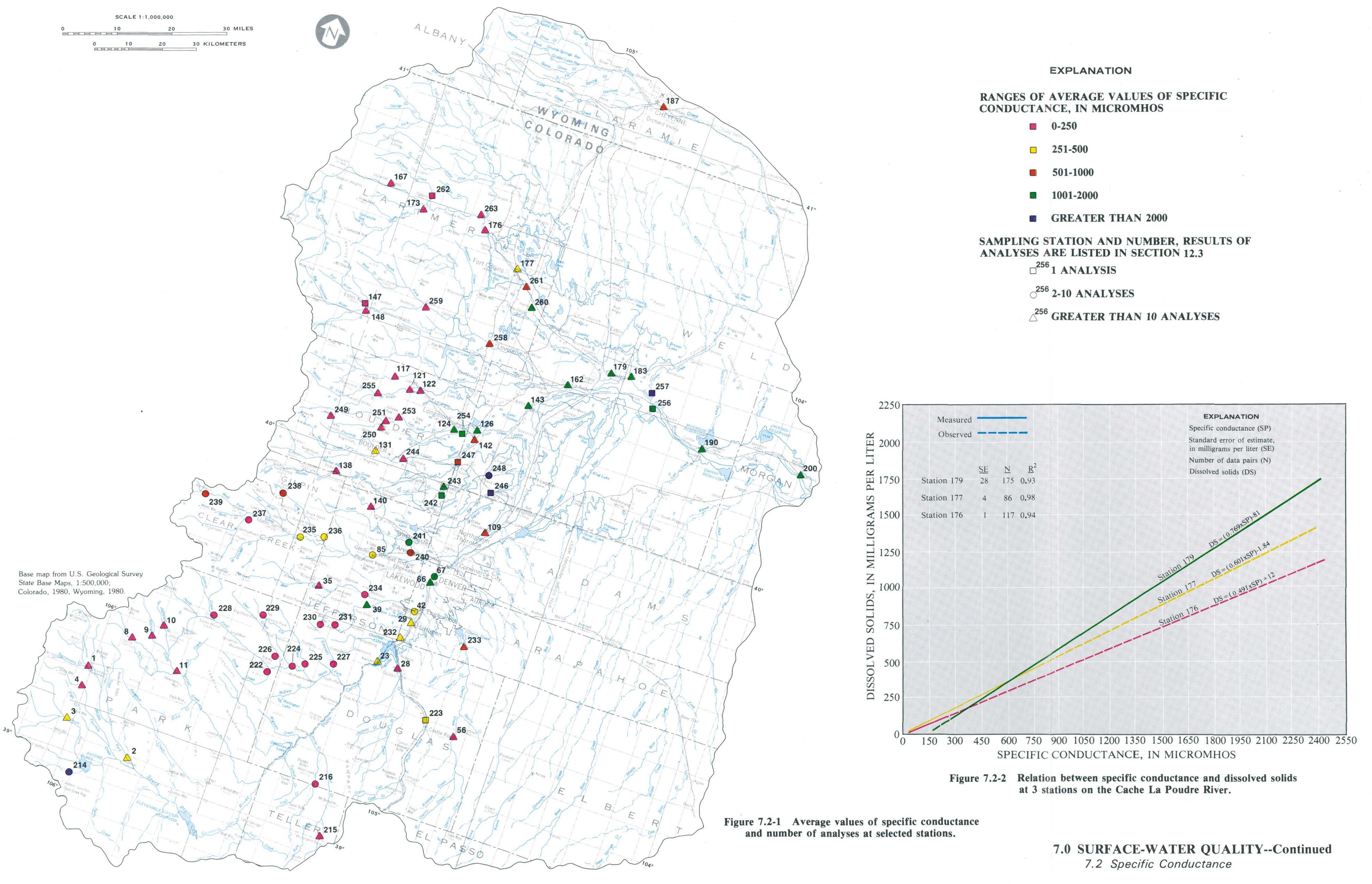




\title{
7.0 SURFACE-WATER QUALITY--Continued $7.3 \mathrm{pH}$
}

\section{The pH of Most Streams is in the Neutral Range}

\author{
The lowest $\mathrm{pH}$ value was found at a station below a metal-mining area.
}

The solubility of many chemical constituents and the biological activity of organisms in water are $\mathrm{pH}$ dependent; thus, $\mathrm{pH}$ (see Section 2.0 for definition) is an important factor in controlling the concentrations of chemical constituents and populations of organisms in the water. The $\mathrm{pH}$ also may affect the suitability of water for various uses. A range of $\mathrm{pH}$ between 6.5 and 9.0 is recommended for most fish and for water used as a source of public-water supplies (U.S. Environmental Protection Agency, 1976).

Median values of $\mathrm{pH}$ ranged from 5.2 to 9.0 (fig. 7.3-1); measured values of $\mathrm{pH}$ ranged from 5.2 to 9.5 (table 7.3-1). Ninety-three percent of the streams in the study area have a median $\mathrm{pH}$ greater than 7.0 (basic solutions); this $\mathrm{pH}$ indicates the influence of carbonate-bearing sedimentary rocks. Median $\mathrm{pH}$ values greater than 8.0 were measured in several streams east of Boulder (stations $124,126,142,247$, and 248 ) which receive drainage from an extensive number of abandoned, underground coal mines. A source of alkalinity in streams draining coal-mining areas may be "rock dust," which is crushed limestone. Rock dust is used in underground coal mines to reduce the possibility of coal dust explosion (Engelke and others, 1981). The smallest $\mathrm{pH}$ value measured was at a station on North Clear Creek (site 238), downstream from a metal-mining area, which historically has produced acid mine drainage (Moran and Wentz, 1974). These acidic conditions result from the breakdown of metal sulfides and other materials as they are exposed to oxidizing conditions on the land surface. The subsequent weathering of these materials can dissolve other minerals containing a variety of metals. 


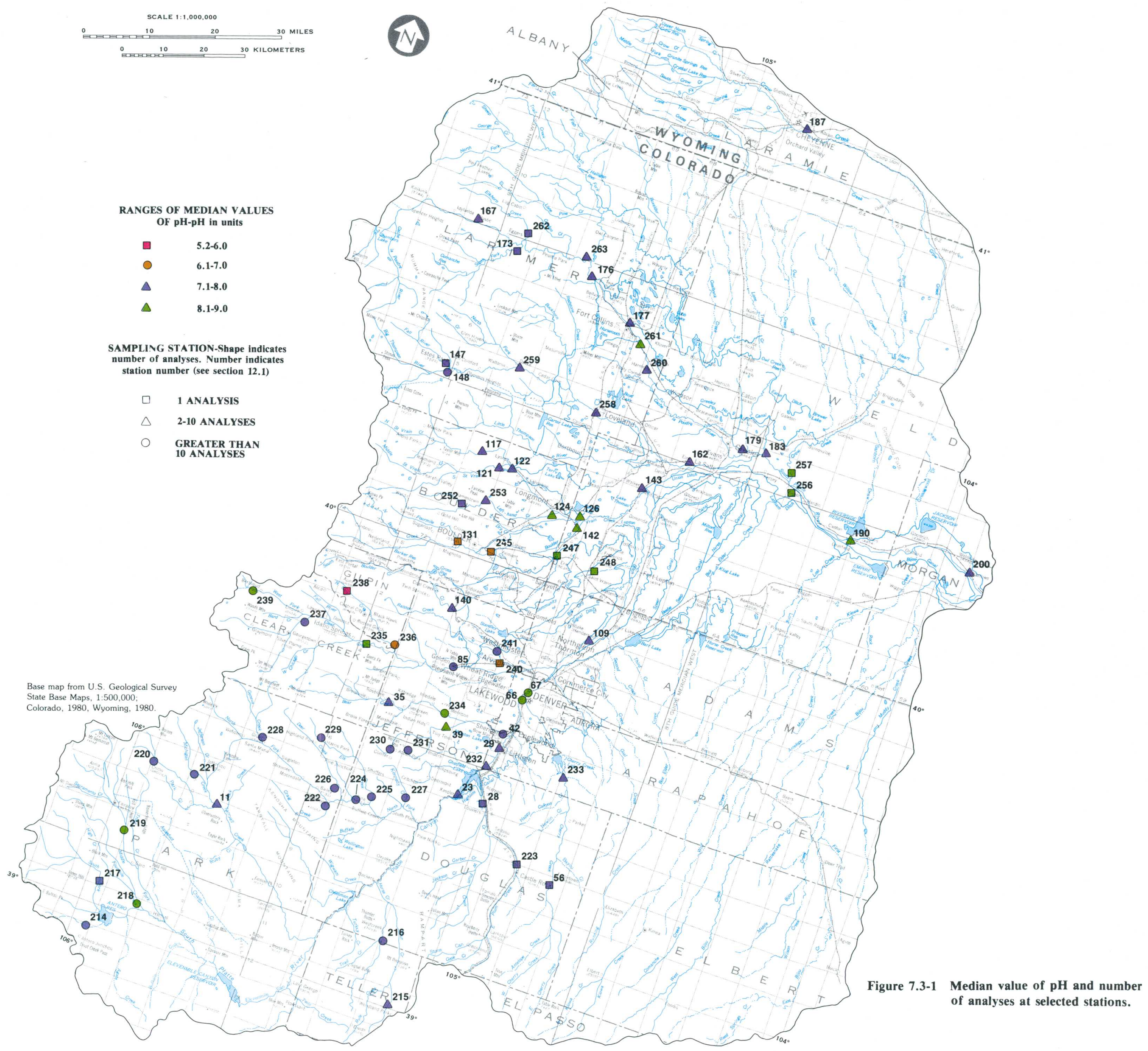

Table 7.3-1 Statistical summary of $\mathrm{pH}$ data from

\begin{tabular}{|c|c|c|c|c|c|}
\hline $\begin{array}{l}\text { tetation nubber } \\
\text { (see fig. }\end{array}$ & $\begin{array}{l}\text { Number of } \\
\text { sanples }\end{array}$ & Median & Minimum & Maximum & $\begin{array}{l}\text { Standard } \\
\text { deviation }\end{array}$ \\
\hline 23 & $\begin{array}{l}48 \\
{ }_{22}^{8}\end{array}$ & $\begin{array}{l}7.7 \\
7.8\end{array}$ & $\begin{array}{l}7.1 \\
7.4\end{array}$ & $\begin{array}{l}8.5 \\
8.2\end{array}$ & $\begin{array}{l}0.3 \\
.2 .\end{array}$ \\
\hline${ }_{29}^{28}$ & $\begin{array}{r}1 \\
42\end{array}$ & $\begin{array}{l}7.5 \\
8.0\end{array}$ & 7.5 & $\begin{array}{l}-.-8 \\
8.8\end{array}$ & .3 \\
\hline $\begin{array}{l}35 \\
39 \\
39\end{array}$ & $\begin{array}{l}24 \\
19\end{array}$ & $\begin{array}{l}7.7 \\
8.3\end{array}$ & $\begin{array}{l}6.8 \\
7.6\end{array}$ & $\begin{array}{l}8.8 \\
8.7\end{array}$ & .3 \\
\hline $\begin{array}{l}42 \\
56 \\
66\end{array}$ & $\begin{array}{l}9 \\
1 \\
7\end{array}$ & $\begin{array}{l}8.0 \\
7.5 \\
8.2\end{array}$ & $\frac{7.1}{8.1}$ & $\frac{8.4}{8.5}$ & \\
\hline $\begin{array}{l}67 \\
67\end{array}$ & $?$ & $\begin{array}{l}8.1 .1 \\
7.4\end{array}$ & $\begin{array}{l}7.1 \\
6.9\end{array}$ & $\begin{array}{l}8.3 \\
8.7\end{array}$ & \\
\hline $\begin{array}{l}1199 \\
117\end{array}$ & $\begin{array}{l}2153 \\
106\end{array}$ & $\begin{array}{l}7.3 \\
7.4\end{array}$ & $\begin{array}{l}6.4 \\
5.4,4\end{array}$ & $\begin{array}{l}8.5 \\
8.6\end{array}$ & \\
\hline $\begin{array}{l}121 \\
122 \\
124\end{array}$ & $\begin{array}{c}105 \\
56 \\
56\end{array}$ & $\begin{array}{l}7.4 \\
7.3 \\
8.3\end{array}$ & $\begin{array}{l}5,6 \\
6.8 \\
.6 .6\end{array}$ & $\begin{array}{l}8.8 \\
8.1 \\
8.5\end{array}$ & \\
\hline $\begin{array}{l}124 \\
126 \\
1.13\end{array}$ & $\begin{array}{c}56 \\
53 \\
51\end{array}$ & $\begin{array}{l}8.2 \\
8.1 \\
66\end{array}$ & 7.5 & $\begin{array}{l}8.6 \\
-6.6\end{array}$ & 3 \\
\hline $\begin{array}{l}140 \\
144\end{array}$ & $\begin{array}{l}54 \\
24\end{array}$ & $\begin{array}{l}7.5 \\
8.5\end{array}$ & $\begin{array}{l}6.9 \\
7.3\end{array}$ & 8.6. & ${ }_{.5}^{-3}$ \\
\hline $\begin{array}{l}1433 \\
147 \\
477\end{array}$ & 207 & $\begin{array}{l}7.8 \\
7.2\end{array}$ & $\begin{array}{l}6.8 \\
--.\end{array}$ & 8.7 & \\
\hline $\begin{array}{l}1848 \\
162\end{array}$ & $\begin{array}{r}6 \\
185\end{array}$ & $\begin{array}{l}7.2 \\
7.9\end{array}$ & $\begin{array}{l}6.9 \\
6.6\end{array}$ & $\begin{array}{l}7.6 \\
8.5\end{array}$ & $\begin{array}{l}-3 \\
.4\end{array}$ \\
\hline 173 & 1 & $\begin{array}{l}1.4 \\
7.6\end{array}$ & 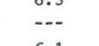 & $\frac{8.8}{8-8}$ & \\
\hline $\begin{array}{l}167 \\
177 \\
179\end{array}$ & $\begin{array}{l}74 \\
24 \\
27\end{array}$ & $\begin{array}{l}7.9 \\
7.9\end{array}$ & $\begin{array}{l}6.1 \\
6.5 .1\end{array}$ & $\begin{array}{l}8.7 \\
8.7\end{array}$ & \\
\hline $\begin{array}{l}1833 \\
1877\end{array}$ & $\begin{array}{l}232 \\
46 \\
46\end{array}$ & $\begin{array}{l}7.7 \\
7.3\end{array}$ & $\begin{array}{l}7.0 \\
6.9\end{array}$ & $\begin{array}{l}8.7 \\
8.2\end{array}$ & 3 \\
\hline $\begin{array}{l}1900 \\
2000\end{array}$ & $\begin{array}{l}4^{166} \\
164 \\
2\end{array}$ & $\begin{array}{l}8.1 \\
8.0 \\
7.8\end{array}$ & $\begin{array}{l}6.8 \\
6.8 \\
7.7\end{array}$ & $\begin{array}{l}8.5 \\
8.7 \\
7.9\end{array}$ & 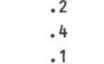 \\
\hline $\begin{array}{l}214 \\
2115 \\
2115\end{array}$ & & $\begin{array}{l}7.0 \\
7.7\end{array}$ & $\begin{array}{l}6.8 \\
7.6\end{array}$ & $\begin{array}{l}8.3 \\
8.3\end{array}$ & $\begin{array}{l}.5 \\
.5\end{array}$ \\
\hline $\begin{array}{l}{ }_{217}^{217} \\
{ }_{218}\end{array}$ & & $\begin{array}{l}7.8 \\
8.4\end{array}$ & 8.3 & 8.5 & .1 \\
\hline $\begin{array}{l}219 \\
220\end{array}$ & & $\begin{array}{l}8.3 \\
7.9\end{array}$ & $\begin{array}{l}8.0 \\
7.8\end{array}$ & $\begin{array}{l}8.5 \\
7.9\end{array}$ & \\
\hline $\begin{array}{l}221 \\
2222 \\
2232\end{array}$ & ${ }^{2}$ & $\begin{array}{l}7.8 \\
7.3\end{array}$ & $\begin{array}{l}7.5 \\
7.2\end{array}$ & $\begin{array}{l}8.1 \\
7.4\end{array}$ & 0.14 \\
\hline $\begin{array}{l}224 \\
2225\end{array}$ & & $\begin{array}{l}7.4 \\
7.5\end{array}$ & $\begin{array}{l}6.9 \\
6.99\end{array}$ & $\begin{array}{l}8.3 \\
8.1\end{array}$ & .6 \\
\hline $\begin{array}{l}226 \\
226 \\
227\end{array}$ & 2 & $\begin{array}{l}7.8 \\
7.8 \\
7.5\end{array}$ & $\begin{array}{l}7.6 \\
7.66 \\
7.3\end{array}$ & $\begin{array}{l}7.9 \\
8.9\end{array}$ & $\begin{array}{l}.6 \\
.2 \\
.4\end{array}$ \\
\hline 228 & 2 & $\begin{array}{l}7.3 \\
7.7\end{array}$ & $\begin{array}{l}7.3 \\
6.4\end{array}$ & $\begin{array}{l}7.3 \\
8.3\end{array}$ & : 8 \\
\hline $\begin{array}{r}230 \\
230\end{array}$ & 4 & $\begin{array}{l}7.6 \\
7.2\end{array}$ & $\begin{array}{l}7.1 \\
7.0\end{array}$ & $\begin{array}{l}7.7 \\
7.3\end{array}$ &.$_{1}^{3}$ \\
\hline 2033 & $\begin{array}{l}20 \\
14 \\
14\end{array}$ & $\begin{array}{l}7.9 \\
7.5\end{array}$ & $\begin{array}{l}7.2 \\
7.1\end{array}$ & $\begin{array}{l}8.5 \\
8.6\end{array}$ & . \\
\hline $\begin{array}{l}234 \\
235\end{array}$ & 7 & $\begin{array}{l}9.0 \\
8.6\end{array}$ & 8.0 & 9.2 & .5 \\
\hline 236 & 3 & $\begin{array}{l}6.2 \\
7.4\end{array}$ & $\begin{array}{l}6.1 \\
7.2\end{array}$ & $\begin{array}{l}6.5 \\
7.6\end{array}$ & .22 \\
\hline $\begin{array}{l}238 \\
2399 \\
2390\end{array}$ & & $\begin{array}{l}5.2 .2 \\
8.5\end{array}$ & 7.7 & 8.6 &. .5 \\
\hline & & $\begin{array}{l}7.8 \\
.8\end{array}$ & 7.7 & 7.9 & .1 \\
\hline 248 & & $\begin{array}{l}0.5 \\
8.2 \\
8.8\end{array}$ & $\ldots$ & $\ldots$ & $\cdots$ \\
\hline $\begin{array}{l}252 \\
252 \\
253\end{array}$ & 1 & $\begin{array}{l}7.4 \\
7.3\end{array}$ & $\overline{5.6}$ & $\overline{8.3}$ & .5 \\
\hline $\begin{array}{l}256 \\
257\end{array}$ & 1 & $\begin{array}{l}8.5 \\
8.4\end{array}$ & $\cdots$ & $\cdots$ & $\cdots$ \\
\hline $\begin{array}{l}258 \\
259\end{array}$ & 1 & $\begin{array}{l}8.0 \\
7.4\end{array}$ & $\begin{array}{l}7.1 \\
6.2\end{array}$ & $\begin{array}{l}8.8 \\
8.9\end{array}$ & .5 \\
\hline $\begin{array}{l}260 \\
261 \\
2060\end{array}$ & & 8.0 & $\begin{array}{l}7.7 \\
6.8\end{array}$ & $\begin{array}{l}8.3 \\
9.0 \\
\end{array}$ & 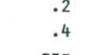 \\
\hline $\begin{array}{l}262 \\
263 \\
263\end{array}$ & 23 & 7.5 & 6.6 & 8.3 & \\
\hline
\end{tabular}




\title{
7.0 SURFACE-WATER QUALITY--Continued \\ 7.4 Sulfate
}

\section{Sulfate Concentrations Generally are Small in Streams in the Area}

\author{
Sulfate concentrations in streams draining the study area \\ were generally less than the recommended maximum \\ concentration for domestic water-supply use.
}

\begin{abstract}
Sulfate concentrations in streams draining the study area were generally less than 250 milligrams per liter which is the recommended maximum concentration for domestic water-supply use. Amounts of sulfate in excess of 250 milligrams per liter, the recommended maximum concentration (U.S. Environmental Protection Agency, 1976), can cause physiological effects, undesirable tastes, and increased costs for water treatment. Average sulfate concentrations ranged from 3.1 to 2,100 milligrams per liter (fig. 7.4-1) for 75 stations in the study area. About 75 percent of samples from the sampling stations had average concentrations of sulfate ranging from 0 to 250 milligrams per liter (table 7.4-1).
\end{abstract}

Coal and associated strata contain sulfur as metallic sulfides, mainly as pyrite $\left(\mathrm{FeS}_{2}\right)$ and marcasite $\left(\mathrm{FeS}_{2}\right.$ ), which are also sources of ferrous iron. During coal-mining operations, pyrite is exposed to air and water; the sulfide is oxidized and releases sulfate, acidity $(\mathrm{H}+)$, and iron to the water. Some of the largest concentrations of sulfate (as high as
2,100 milligrams per liter) were measured downstream from coal-mining areas east of Boulder. However, according to Wentz (1974), the sulfur content of coal is small in Colorado; consequently, large sulfate concentrations and associated acid mine drainage are generally not a major water-quality problem in Colorado streams.

Sulfate concentrations occurs in water not only because of land use associated with mining, but also occurs naturally from weathering of geologic formations. One of the most extensive and important occurrences of sulfate is in evaporite sediments. Sulfate concentrations generally are larger in the eastern plains of the study area as a result of weathering and extensive irrigation practices. Wentz (1974) indicated that sulfate appears to be a poor indicator of mine drainage in areas such as the plains and plateau regions of Colorado, where large background concentrations of sulfate occur. 


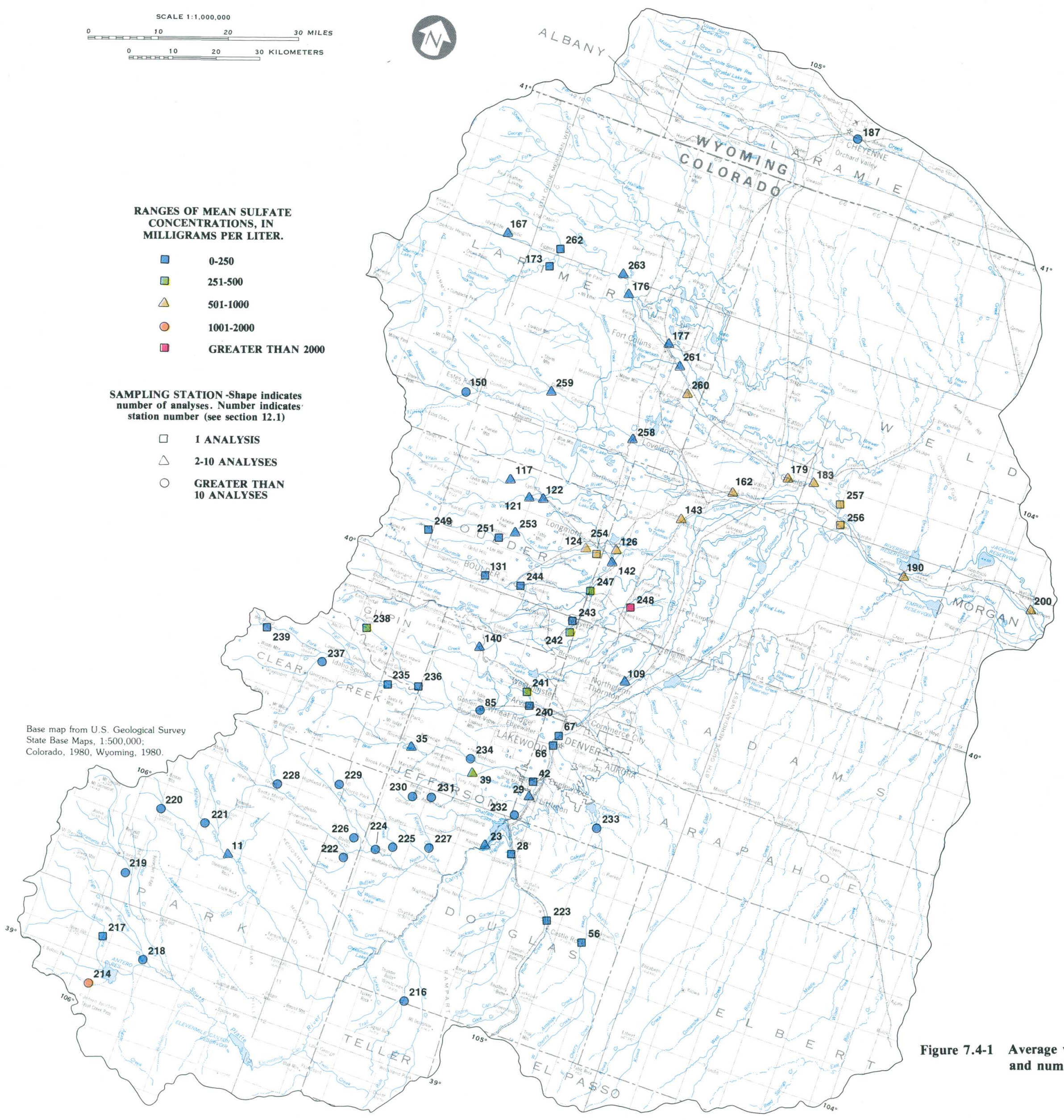

Table 7.4-1 Statistical summary of sulfate concentrations at selected stations

\begin{tabular}{|c|c|c|c|c|c|}
\hline $\begin{array}{l}\text { Station nubber } \\
\text { see fig } 7,74-1)\end{array}$ & $\begin{array}{l}\text { Number of } \\
\text { Sanples }\end{array}$ & vedian & Minimum & Maximum & $\begin{array}{l}\text { Standard } \\
\text { deviation }\end{array}$ \\
\hline 23 & $\begin{array}{l}48 \\
10 \\
10\end{array}$ & $\begin{array}{l}21 \\
43\end{array}$ & $\begin{array}{l}1.0 \\
32\end{array}$ & $\begin{array}{l}66 \\
61\end{array}$ & $\begin{array}{c}13.9 \\
8.5\end{array}$ \\
\hline $\begin{aligned}{ }_{29}^{88} \\
{ }_{29}\end{aligned}$ & $\frac{1}{36}$ & $\begin{array}{l}44 \\
67\end{array}$ & $15^{--}$ & ${ }_{120}^{--}$ & $\ddot{22.5}$ \\
\hline $\begin{array}{l}35 \\
39 \\
34\end{array}$ & $\begin{array}{l}16 \\
15 \\
15\end{array}$ & $\begin{array}{c}11 \\
450 \\
410\end{array}$ & $\begin{array}{c}0.6 \\
150 \\
150\end{array}$ & $\begin{array}{r}23 \\
1140 \\
1140\end{array}$ & $\begin{array}{r}4.99 \\
273.8\end{array}$ \\
\hline $\begin{array}{l}526 \\
56 \\
66\end{array}$ & 1 & $\begin{array}{l}110 \\
13 \\
160\end{array}$ & $\ddot{-}$ & $\ddot{~} \because$ & $\ddot{z}$ \\
\hline $\begin{array}{l}67 \\
85\end{array}$ & $i_{9}^{1}$ & $\begin{array}{l}100 \\
73\end{array}$ & $32--$ & ${ }_{93}^{--}$ & $\frac{-.}{18.3}$ \\
\hline $\begin{array}{l}109 \\
117 \\
117\end{array}$ & $\begin{array}{l}194 \\
82\end{array}$ & $\begin{array}{c}160 \\
4.1\end{array}$ & $\begin{array}{l}36 \\
4.5 \\
1.5\end{array}$ & $\begin{array}{l}310 \\
16.0\end{array}$ & $\begin{array}{l}18.3 \\
62.0 \\
2.2\end{array}$ \\
\hline $\begin{array}{l}121 \\
122\end{array}$ & $\begin{array}{l}83 \\
{ }_{57}^{83}\end{array}$ & $\begin{array}{l}5.7 \\
7.7\end{array}$ & $\begin{array}{l}2.2 \\
1.4\end{array}$ & $\begin{array}{l}17.0 \\
19.0\end{array}$ & $\begin{array}{l}2.4 \\
3.2\end{array}$ \\
\hline 124 & $\begin{array}{l}35 \\
53\end{array}$ & $\begin{array}{l}510 \\
510\end{array}$ & $\begin{array}{c}110 \\
62\end{array}$ & $\begin{array}{l}750 \\
910\end{array}$ & $\begin{array}{c}1148.3 \\
165.0\end{array}$ \\
\hline $\begin{array}{l}1 \\
1931 \\
140\end{array}$ & $\begin{array}{l}54 \\
54\end{array}$ & $\begin{array}{l}10 \\
12 \\
200\end{array}$ & $\begin{array}{l}1.0 \\
60\end{array}$ & $\begin{array}{l}25{ }^{2} \\
406\end{array}$ & $\begin{array}{r}4.9 \\
11.9\end{array}$ \\
\hline $\begin{array}{l}142 \\
143 \\
143\end{array}$ & $\begin{array}{l}24 \\
176 \\
176\end{array}$ & 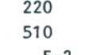 & $\begin{array}{l}60 \\
86\end{array}$ & $\begin{array}{l}4 \begin{array}{l}400 \\
960\end{array}\end{array}$ & $\begin{array}{l}1144.9 \\
147.0\end{array}$ \\
\hline $\begin{array}{l}1560 \\
162\end{array}$ & $\begin{array}{c}152 \\
152\end{array}$ & $\begin{array}{l}57.2 \\
870\end{array}$ & 97 & $1460^{-1}$ & 269.3 \\
\hline 1773 & ${ }_{118}^{1}$ & $\begin{array}{l}6.1 \\
6.5\end{array}$ & $\begin{array}{l}\because .2 \\
1.2\end{array}$ & 16 & 2.8 \\
\hline 177 & $\begin{array}{l}77 \\
175\end{array}$ & $\begin{array}{l}69 \\
690\end{array}$ & $\begin{array}{r}4.7 \\
65\end{array}$ & $\begin{array}{l}150 \\
950\end{array}$ & $\begin{array}{l}40.6 \\
40556\end{array}$ \\
\hline $\begin{array}{l}183 \\
187\end{array}$ & $\begin{array}{r}235 \\
6 \\
2\end{array}$ & $\begin{array}{c}510 \\
77\end{array}$ & $\begin{array}{l}95 \\
57\end{array}$ & $\begin{array}{l}770 \\
110\end{array}$ & $\begin{array}{l}156.8 \\
1996\end{array}$ \\
\hline $\begin{array}{l}190 \\
200 \\
2014\end{array}$ & $\begin{array}{l}465 \\
442 \\
4\end{array}$ & $\begin{array}{c}510 \\
620 \\
0.502\end{array}$ & $\begin{array}{r}150 \\
150 \\
1800\end{array}$ & $\begin{array}{r}650 \\
1400 \\
2100\end{array}$ & $\begin{array}{l}96.6 \\
968.5 \\
1686.5\end{array}$ \\
\hline $\begin{array}{l}216 \\
2116 \\
217\end{array}$ & & $\begin{array}{l}1950 \\
12 \\
110\end{array}$ & 11 & $\begin{array}{r}100 \\
12\end{array}$ & $\begin{array}{c}2.12 .1 \\
0.7\end{array}$ \\
\hline $\begin{array}{l}218 \\
219\end{array}$ & & $\begin{array}{l}56 \\
33\end{array}$ & $\begin{array}{l}54 \\
15\end{array}$ & $\begin{array}{l}58 \\
44 \\
44\end{array}$ & $\begin{array}{r}2.8 \\
15.5\end{array}$ \\
\hline $\begin{array}{l}2200 \\
2220\end{array}$ & 2 & $\begin{array}{l}16 \\
16 \\
26\end{array}$ & $\begin{array}{l}13 \\
17 \\
17\end{array}$ & 19 & $\begin{array}{l}4.2 \\
4.2 \\
12.7\end{array}$ \\
\hline $\begin{array}{l}222 \\
223\end{array}$ & 2 & $\begin{array}{c}5.8 \\
31\end{array}$ & 5.6 & 5.9 & 0.2 \\
\hline 2224 & ${ }_{4}^{4}$ & $\begin{array}{l}18 \\
8.7\end{array}$ & $\begin{array}{c}12 \\
6.4\end{array}$ & $\begin{array}{l}23 \\
13 \\
\end{array}$ & $\begin{array}{l}4.7 \\
2.9\end{array}$ \\
\hline $\begin{array}{l}2267 \\
2228 \\
228\end{array}$ & 4 & $\begin{array}{l}\text {.5.2 } \\
21\end{array}$ & $\begin{array}{l}\text { 每. } \\
13 \\
15\end{array}$ & $\begin{array}{l}\text { 16.9 } \\
27\end{array}$ & $\begin{array}{l}0.9 \\
1.3 \\
8.5\end{array}$ \\
\hline 229 2290 & $\begin{array}{l}4 \\
4\end{array}$ & $\begin{array}{l}4.9 \\
5.9\end{array}$ & $\begin{array}{l}4.0 \\
4.6 \\
4.0\end{array}$ & $\begin{array}{l}5.8 \\
8.4\end{array}$ & $\begin{array}{l}0.9 \\
1.8\end{array}$ \\
\hline 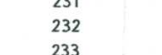 & 8 & $\begin{array}{l}6.8 \\
63 \\
20\end{array}$ & $\begin{array}{c}28.9 \\
28\end{array}$ & $\begin{array}{l}146 \\
1300 \\
307\end{array}$ & $\begin{array}{l}3.1 \\
41.9\end{array}$ \\
\hline $\begin{array}{l}2033 \\
2234 \\
2025\end{array}$ & 8 & 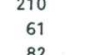 & $\begin{array}{l}450 \\
15\end{array}$ & $\begin{array}{l}370 \\
94\end{array}$ & $\begin{array}{l}91.9 \\
26.2\end{array}$ \\
\hline $\begin{array}{l}236 \\
237\end{array}$ & $i_{2}$ & $\begin{array}{r}250 \\
250 \\
23\end{array}$ & $22--$ & $\stackrel{-}{23}$ & $\begin{array}{l}-\because \\
0.7\end{array}$ \\
\hline $\begin{array}{l}2338 \\
2399\end{array}$ & $i$ & $\begin{array}{l}290 \\
\begin{array}{r}190 \\
180\end{array}\end{array}$ & $\because \because$ & $\because:$ & $\because \because$ \\
\hline 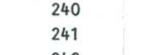 & 1 & 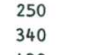 & $\ddot{-}$ & 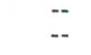 & $\ddot{.}$ \\
\hline $\begin{array}{l}2424 \\
243 \\
243\end{array}$ & 1 & $\begin{array}{l}430 \\
110 \\
\end{array}$ & $\ddot{~}$ & -- & $\ddot{~}$ \\
\hline 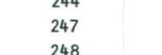 & 1 & $\begin{aligned} 260 \\
260 \\
200\end{aligned}$ & 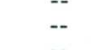 & -- & 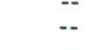 \\
\hline $\begin{array}{l}249 \\
2.29 \\
2\end{array}$ & 1 & $\begin{array}{r}3.1 \\
20\end{array}$ & 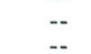 & -. & -- \\
\hline $\begin{array}{l}253 \\
2.254 \\
2.45\end{array}$ & 73 & $\begin{array}{l}41 \\
750\end{array}$ & 6.4 & 130 & 27.2 \\
\hline 2567 & 1 & $\begin{array}{l}630 \\
6300 \\
8600\end{array}$ & $\ddot{--}$ & $\ddot{-}$ & $\because-$ \\
\hline $\begin{array}{l}2{ }_{258}^{259} \\
2.99\end{array}$ & $\begin{array}{l}28 \\
128 \\
15\end{array}$ & $\begin{array}{l}210 \\
7.1\end{array}$ & $\begin{array}{l}{ }_{20} \\
2.8\end{array}$ & $\begin{array}{l}670 \\
15\end{array}$ & $\begin{array}{c}191.2 \\
3.1\end{array}$ \\
\hline $\begin{array}{l}260 \\
261\end{array}$ & ${ }_{46}^{21}$ & $\begin{array}{l}720 \\
100\end{array}$ & $\begin{array}{l}32 \\
8.6\end{array}$ & $\begin{array}{l}1200 \\
320\end{array}$ & $\begin{array}{l}398.98 \\
56.4\end{array}$ \\
\hline 263 & $\begin{array}{l}1 \\
24\end{array}$ & $\begin{array}{l}7.8 \\
5.1\end{array}$ & 0.7 & $12-$ & 3.4 \\
\hline
\end{tabular}




\title{
7.0 SURFACE-WATER QUALITY--Continued \\ 7.5 Iron
}

\section{Dissolved and Total Recoverable Concentrations of Iron Generally are Small in the Area but Exceed Water-Quality Standards at Some Sites}

\author{
The largest dissolved iron concentrations were found downstream of a historical \\ metal mining area; the larger total recoverable iron concentrations are \\ probably associated with metal mining, municipal, and industrial \\ land uses as well as naturally occurring sources.
}

Objectionable qualities including tastes and staining can be imparted to water by small concentrations of iron, limiting the water's use for many domestic and industrial purposes. A maximum limit of 300 micrograms per liter of dissolved iron is recommended in domestic water supplies, and a criteria level of 1,000 micrograms per liter total recoverable iron is recommended for aquatic-life maintenance (U.S. Environmental Protection Agency, 1976).

Iron is an abundant and widespread constituent of rocks and soils, especially clay soils, where it is usually a major constituent. Iron is an essential trace element required by plants and animals; however, it may be a limiting factor for algal growth in some waters. The ferrous, or bivalent iron $\left(\mathrm{Fe}^{++}\right)$, and the ferric, or trivalent iron $\left(\mathrm{Fe}^{+++}\right)$, are the primary forms that occur in the aquatic environment. The ferrous iron $\left(\mathrm{Fe}^{++}\right)$ form occurs in waters devoid of oxygen, such as ground water or pumped mine water. Also, in sediments, iron occurs in the ferrous form, often combined with sulfur as polysulfides, pyrite or marcasite $\left(\mathrm{FeS}_{2}\right)$. The ferric iron $\left(\mathrm{Fe}^{+++}\right)$form generally is insoluble. Major sources of iron pollution are industrial wastes and mine drainage. In the presence of dissolved oxygen, insoluble ferric iron precipitates (Yellow Boy) are formed in many streams draining coal-mining regions. Sorption of these precipitates on stream sediment results in large total recoverable iron concentrations.

Average dissolved iron concentrations ranged from 0 to 14,000 micrograms per liter, with 4 out of 67 sites (16 percent) exceeding the 300-micrograms per liter limit recommended for domestic water supplies (fig. 7.5-1, and table 7.5-1). Average total iron concentrations ranged from 30 to 19,000 micrograms per liter, with 7 out of 25 sites (28 percent) exceeding the 1,000-micrograms per liter limit recommended for aquatic-life maintenance. Ranges in average concentrations of dissolved and total recoverable iron also are shown in table 7.5-1. The largest dissolved-iron concentrations were measured in North Clear Creek (stations 236 and 238), which drains a historical metal-mining area. According to Wentz (1974), dissolved-iron concentrations in Colorado streams are roughly comparable in unmined and coal-mining areas, whereas they are often considerably larger in metal-mining areas. The larger total recoverable iron concentrations are probably associated with metal mining, municipal, and industrial land uses, as well as with the suspended sediment and drainage from naturally occurring sources in sedimentary and igneous rocks. 


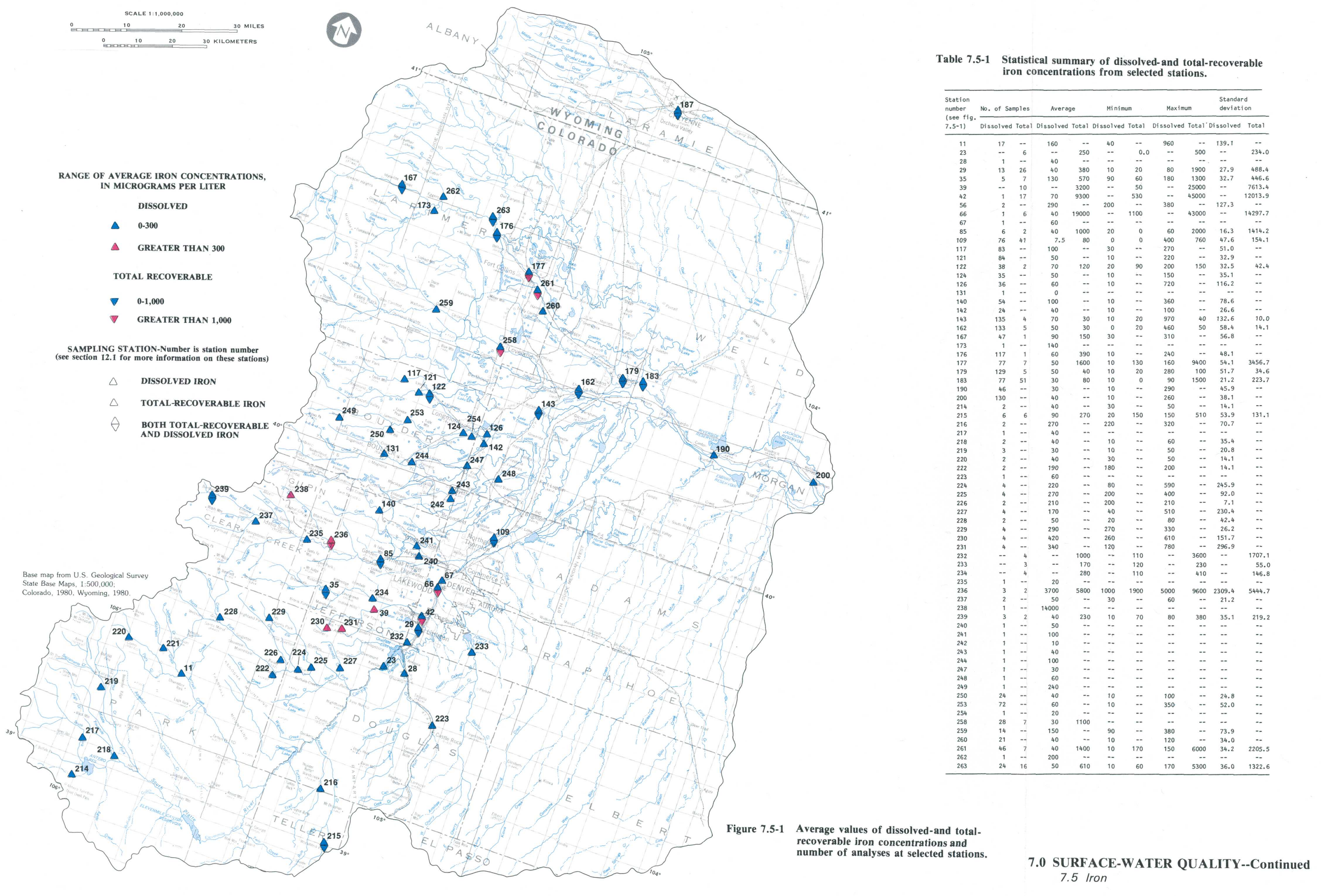




\title{
7.0 SURFACE-WATER QUALITY--Continued \\ 7.6 Manganese
}

\section{Dissolved and Total Recoverable Concentrations of Manganese Vary Widely in the Area}

\author{
Concentrations of manganese as well as most trace metals occur in greater \\ concentrations in Colorado streams draining metal-mining areas \\ than in streams draining coal-mining or unmined areas.
}

Small concentrations of manganese can impart objectionable qualities to water, including unpleasant tastes, and staining, thereby limiting water's use for many domestic and industrial purposes. A maximum limit of 50 micrograms per liter of dissolved manganese is recommended by the U.S. Environmental Protection Agency (1976) in domestic water supplies. In addition, a limit of 200 micrograms per liter total recoverable manganese is recommended in waters used for agricultural purposes (Colorado Department of Health, 1979) and a criteria level of 1,000 micrograms per liter total recoverable manganese is recommended for aquatic-life maintenance (Davies and Goettl, 1976).

Manganese occurs naturally in soils and rocks, and is an essential element for plant and animal metabolism. Soils rich in organic matter are a major source of manganese to natural waters. According to Hem (1970), manganese concentrations are often greater than 1,000 micrograms per liter in streams that have received acid mine drainage from coal mines. However, concentrations of most trace metals, including manganese, occur in greater concentrations in Colorado streams draining metal-mining areas than in streams draining coal-mining or unmined areas (Wentz, 1974).

Average concentrations of dissolved and total recoverable manganese for streams in the study area are shown in figure 7.6-1. Ranges in measured concentrations are shown in table 7.6-1. Average dissolved concentrations ranged from 0 to 7,600 micrograms per liter, with the five largest concentrations occurring in Clear Creek downstream from a metal-mining area that has been documented as being a source of acid-mine drainage. Of 63 stations analyzed for dissolved manganese, 30 stations (46 percent) had average concentrations greater than the 50 micrograms per liter limit recommended for domestic water-supply use (table 7.6-1). Average total recoverable concentrations ranged from 10 to 3,400 micrograms per liter, with only 2 stations on Clear Creek (stations 236 and 239), out of 18 stations analyzed, exceeding the maximum limit of 1,000 micrograms per liter recommended for maintenance of aquatic life. 


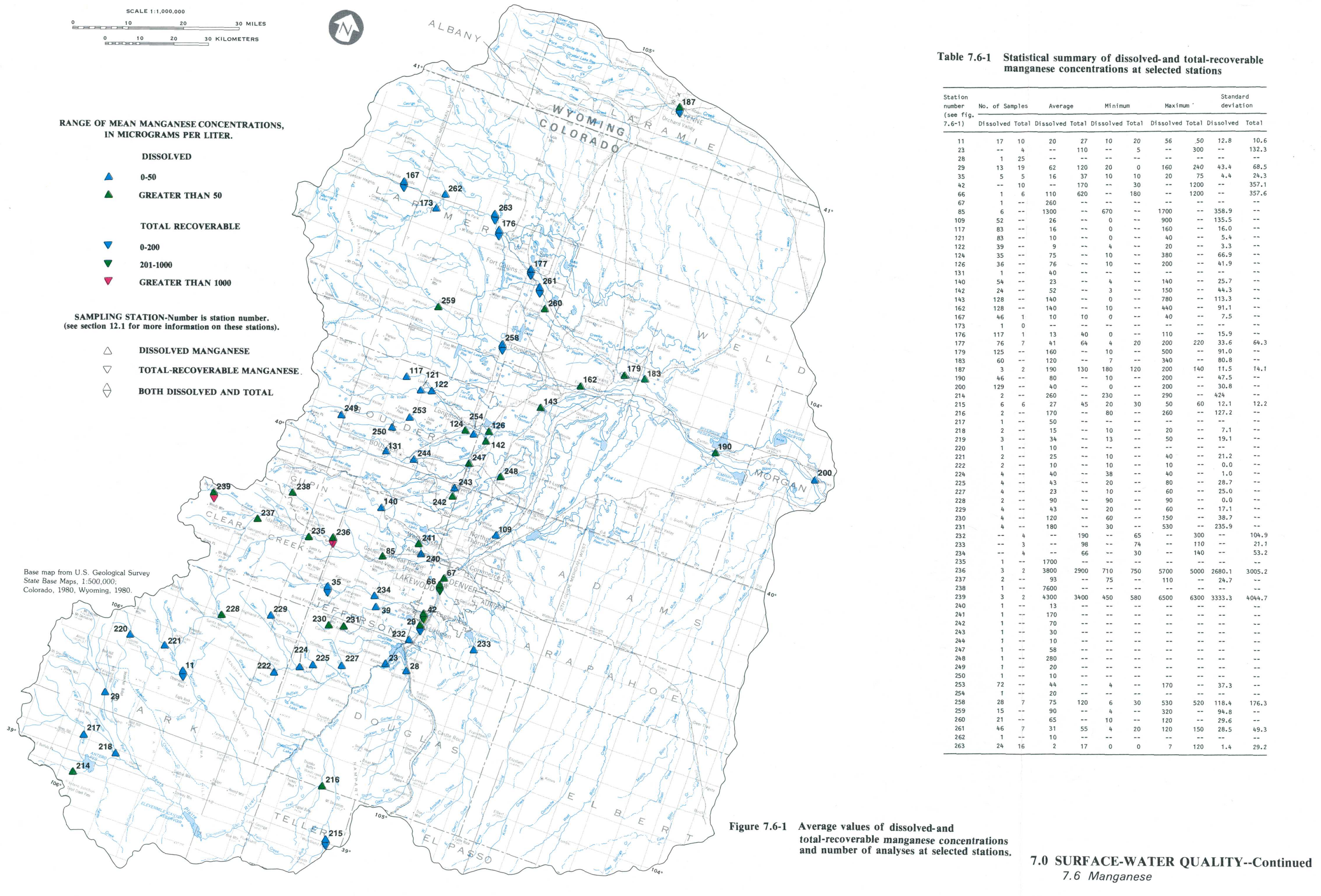




\title{
7.0 SURFACE-WATER QUALITY--Continued \\ 7.7 Trace Elements
}

\section{Dissolved and Total Recoverable Concentrations for Some Trace Elements Exceed Recommended Limits}

\author{
Concentrations of cadmium, copper, lead, mercury, selenium, and zinc \\ occur in greater concentrations in Colorado streams draining metal-mining \\ areas than in streams draining coal-mining or unmined areas.
}

Trace elements, or "minor" constituents, are denoted as substances that typically occur in water in concentrations less than 1,000 micrograms per liter (Hem, 1970). In small concentrations these substances are essential for life; however, in larger concentrations they can be toxic to plants and animals. The criteria levels for dissolved trace elements in domestic water supplies analyzed for the study area (fig. 7.7-1) are: arsenic, 50 micrograms per liter; cadmium, 10 micrograms per liter; copper, 1,000 micrograms per liter; lead, 50 micrograms per liter; mercury, 2 micrograms per liter; selenium, 10 micrograms per liter; and zinc, 5,000 micrograms per liter. Other criteria levels for total recoverable trace element concentrations are recommended for water used for irrigation and for aquatic-life maintenance. Various maximum criteria levels of each trace element in water have been recommended by the U.S. Environmental Protection Agency (1976) and the Colorado Department of Health (1979).

Major sources of trace elements generally include soils, nearly all geologic strata, and atmospheric fallout. Large concentrations of trace elements can occur naturally in thermal springs or acidic ground waters, but generally they are associated with municipal and industrial wastes or with mine drainage. In coal-mining areas, accelerated weathering of pyritic minerals present in coal-mine spoils produces acidic runoff to streams. However, concentrations of cadmium, copper, iron, lead, manganese, and zinc occur in greater concentrations in Colorado streams draining metal-mining areas than in streams draining coal-mining or unmined areas (Wentz, 1974). Of these trace elements, cadmium, copper, manganese, and zinc tend to occur together. In addition, arsenic, mercury, and selenium do not seem to occur at anomalously large levels in metal- or coal-mining areas of Colorado (Wentz, 1974).

In Area 59, concentrations of most dissolved trace elements in streams generally are small. However, dissolved cadmium and lead concentrations at one station, and dissolved selenium concentrations at three stations exceeded maximum water-quality limits (section 12.4 in the "Supplemental Information" section at the end of this report). Of these, only the large selenium concentrations would be associated with mine drainage. In general, dissolved trace elements that may occur in concentrations that exceed criteria levels in and near mining areas decrease rapidly downstream. This decrease occurs because of dilution, chemical reactions and precipitation on sediments caused by near-neutral $\mathrm{pH}$ $(6.0-8.0)$ water in streams.

Total recoverable trace element concentrations exceeded agricultural or aquatic-life criteria at 21 of 67 stations sampled (see section 12.4). The aquatic-life criteria of some of these elements are given in terms of the 96-hour LC50 (U.S. Environmental Protection Agency, 1976). This term is defined as the concentration of a substance that will be fatal to 50 percent of the test organisms during a 96 -hour exposure time. The Colorado Department of Health (1979) also recommends criteria levels based on the hardness of the stream water. The total recoverable concentrations of trace elements shown in section 12.4 are those that exceeded the maximum criteria level associated with hardness. All other trace elements analyzed at sites shown in figure 7.7-1, and not listed in section 12.4 , were within maximum waterquality limits. 


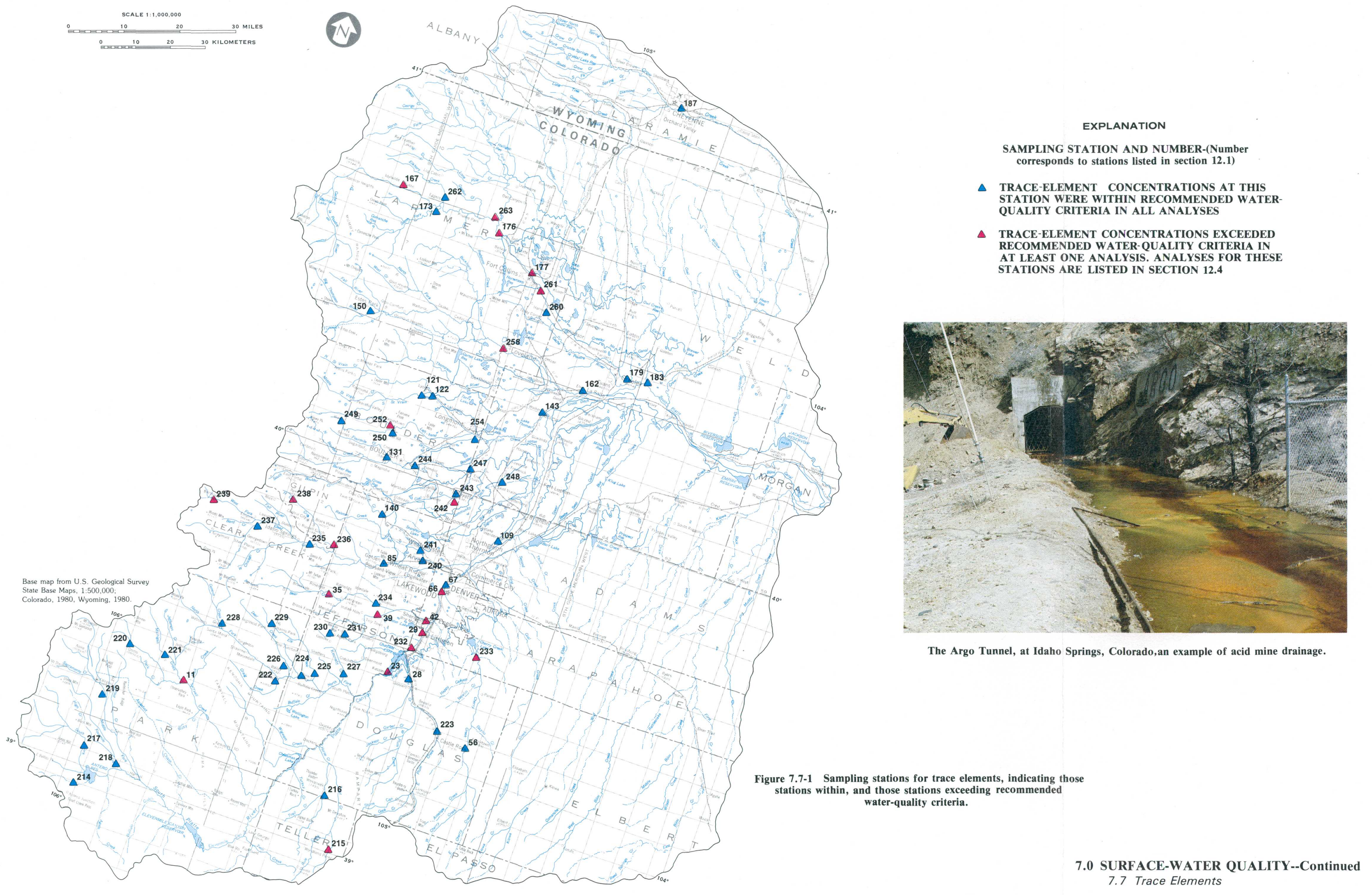




\title{
Annual Suspended-Sediment Yields Range up to 1,178 Tons per Square Mile per Year
}

\author{
Suspended-sediment yields within the study area are low \\ near the foothills and increase in an easterly direction.
}

\begin{abstract}
Although suspended-sediment data have been collected at 27 streamflow stations within the study area, sufficient data do not exist for correlation with land use in the study area. Mining has occurred at several locations within the basin, but suspended-sediment data available are from stations that do not have much mining upstream.

Minimum suspended-sediment yield within the basin was 13.3 tons per square mile per year. Maximum suspended-sediment yield, in the southeast part of the study area, was 1,178 tons per square mile per year. Suspended-sediment yields within the study area are low near the foothills and increase in an easterly direction, as shown by the suspended-sediment yield map and photographs in
\end{abstract}

figure 8.1-1. This increase in suspended-sediment yield in the eastern part of the study area results from an increase in high-intensity thunderstorms, more easily erodible soils, and sparse vegetation cover, compared to the area nearer to the foothills. This suspended-sediment yield map (fig. 8.1-1) was developed from existing data at 22 stations, as well as other available information. Zones of equal suspended-sediment yield reflect relatively normal variations in suspended-sediment yield that occur in the basin, except those variations largely resulting from human activity. For further information on sediment in Area 59, see Kircher (1981a, 1981b, and 1982) and Mundorf (1964 and 1968). 


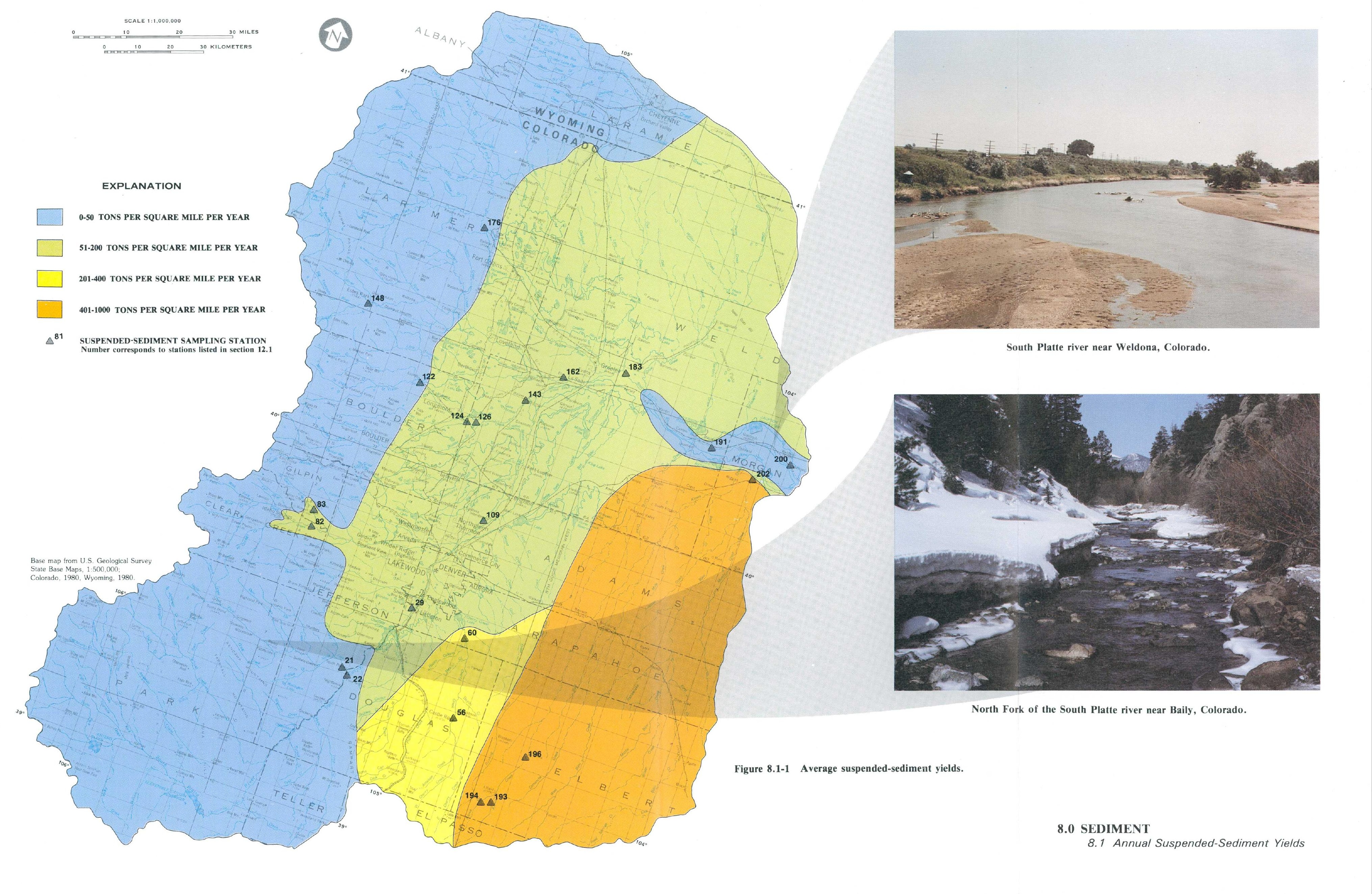




\title{
8.0 SEDIMENT--Continued \\ 8.2 Sediment Transport
}

\section{Suspended-Sediment Concentrations and Average Annual Suspended-Sediment Discharge are Highly Variable within the Area}

\author{
The eastern plains of the area are characterized \\ by high suspended-sediment concentrations; nearer \\ to the foothills lower suspended-sediment concentrations occur.
}

Suspended-sediment concentration data were collected at several locations within the area (fig. 8.2-1); they ranged from 1 to 31,300 milligrams per liter. Suspended-sediment concentration is extremely variable with time and location. The basin upstream of station 196 is characterized by high intensity thunderstorms, moderate to steep land slopes, easily erodible soils, sparse vegetative cover, and high suspended-sediment concentrations (fig. 8.2-2). Nearer to the foothills, lower suspended-sediment concentrations occur, because stream discharge is supplied by snowmelt runoff; more vegetative cover exists, and less-erodible soils occur.

Relations between suspended-sediment discharge and water discharge were developed at eight stations to depict spatial variability. The relation shows that suspended-sediment discharge increases at a faster rate than water discharge does, indicating that suspended-sediment concentration increases rapidly with increasing discharge. In addition, some basins have a larger suspendedsediment discharge for a certain water discharge, indicating a larger initial supply of sediment to the stream either from the watershed or the channel itself.

The percent of suspended-sediment finer than sand (finer than 0.062 millimeters) decreases with distance downstream from the source areas (fig. $8.2-1$ ), indicating that more sand is picked up by the river as it flows over the alluvial deposits in the eastern part of the study area. Also, median bed-material size decreases in a downstream direction, showing that bed-material composition is mostly sand in the easterly part of the study area (fig. 8.2-1). 


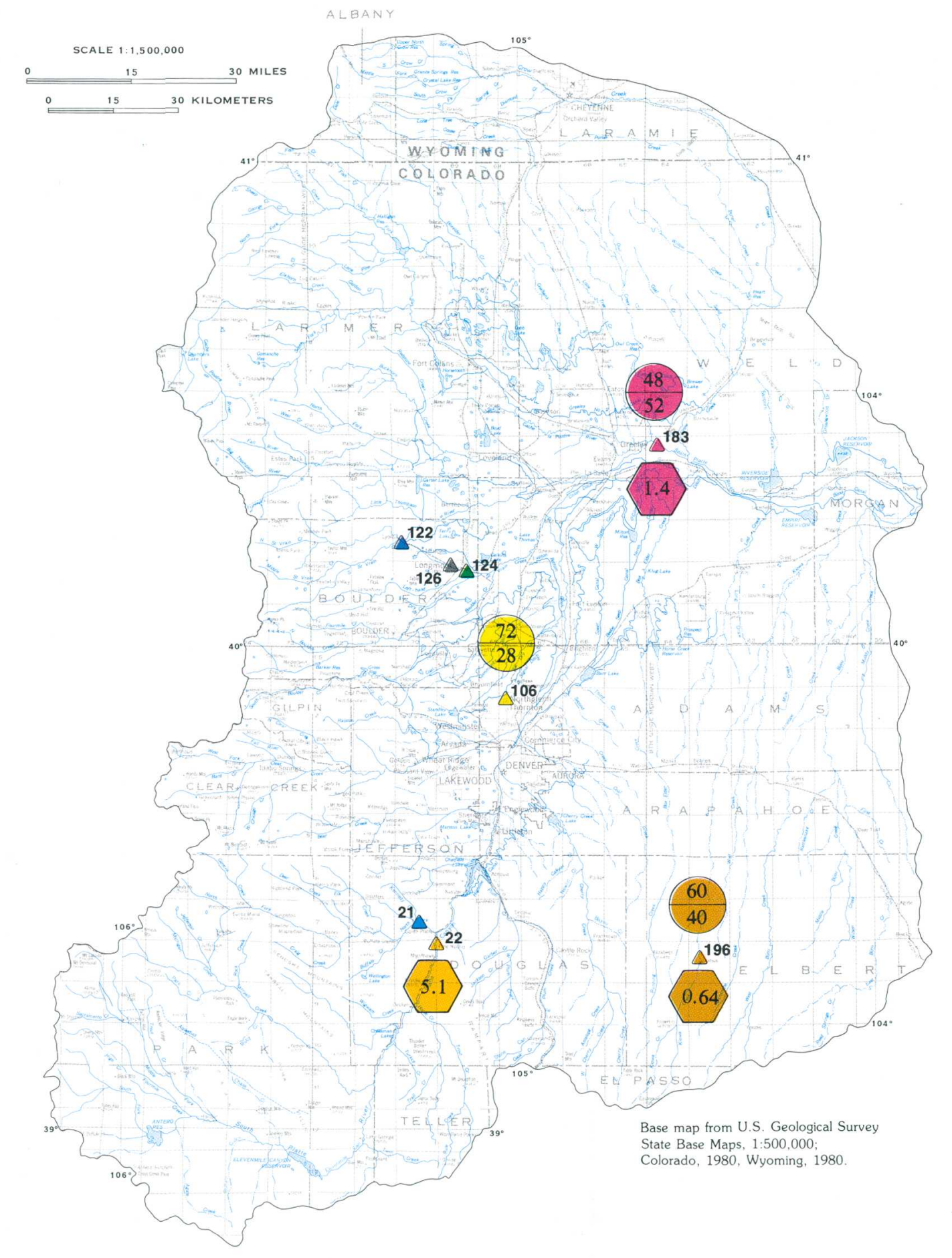

Figure 8.2-1 Location of selected suspended-sediment sampling stations, showing suspended-sediment size and bed-material size.

\section{EXPLANATION}

$\triangle^{122}$ SUSPENDED-Sediment sampling station location and number

53
47 - PERCENT SUSPENDED-Sediment finer than 0.062 millimeters

1.5 PARTICAL SIZE OF BED-Material of which 50 percent of the

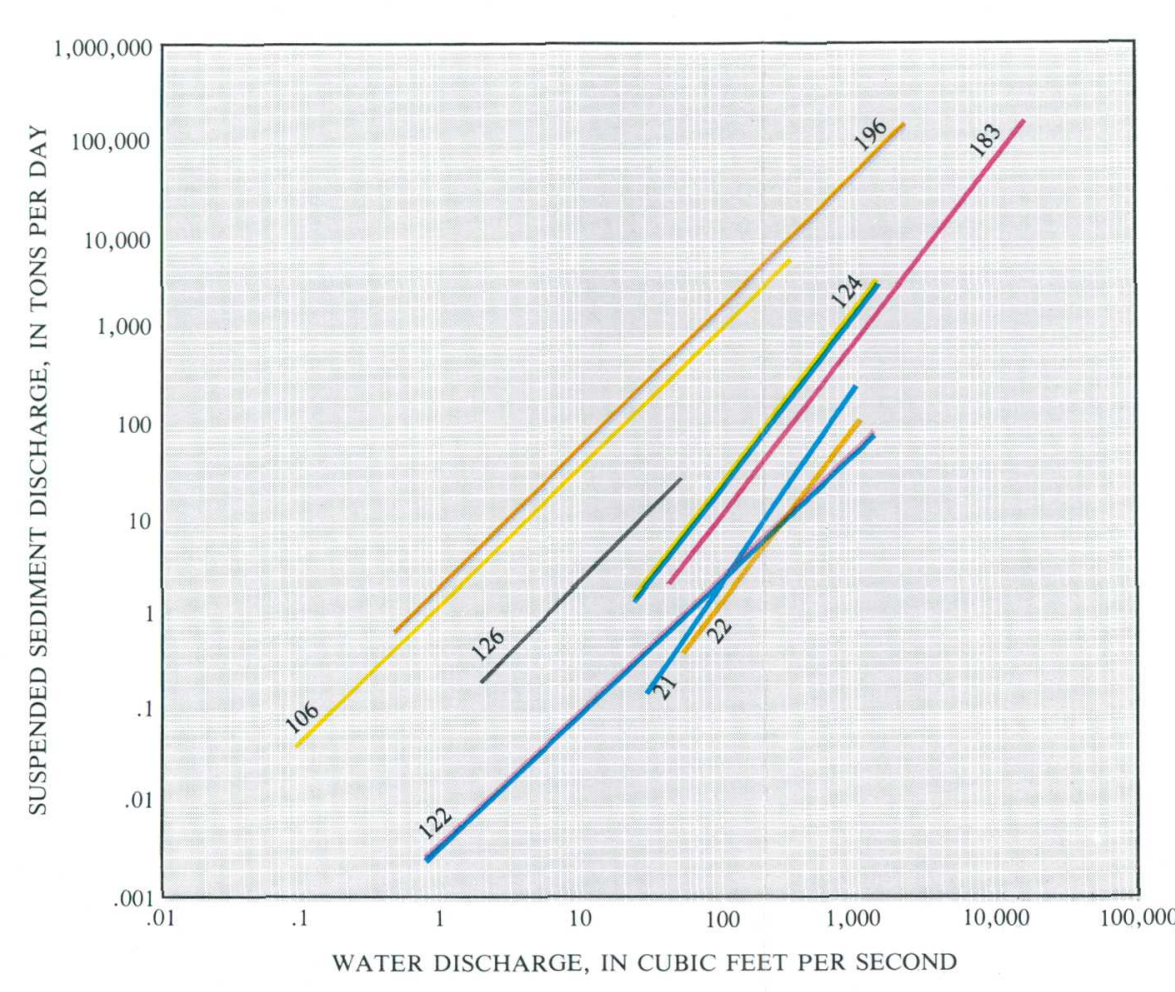

Figure 8.2-2 Relation between suspended-sediment discharge and water discharge.

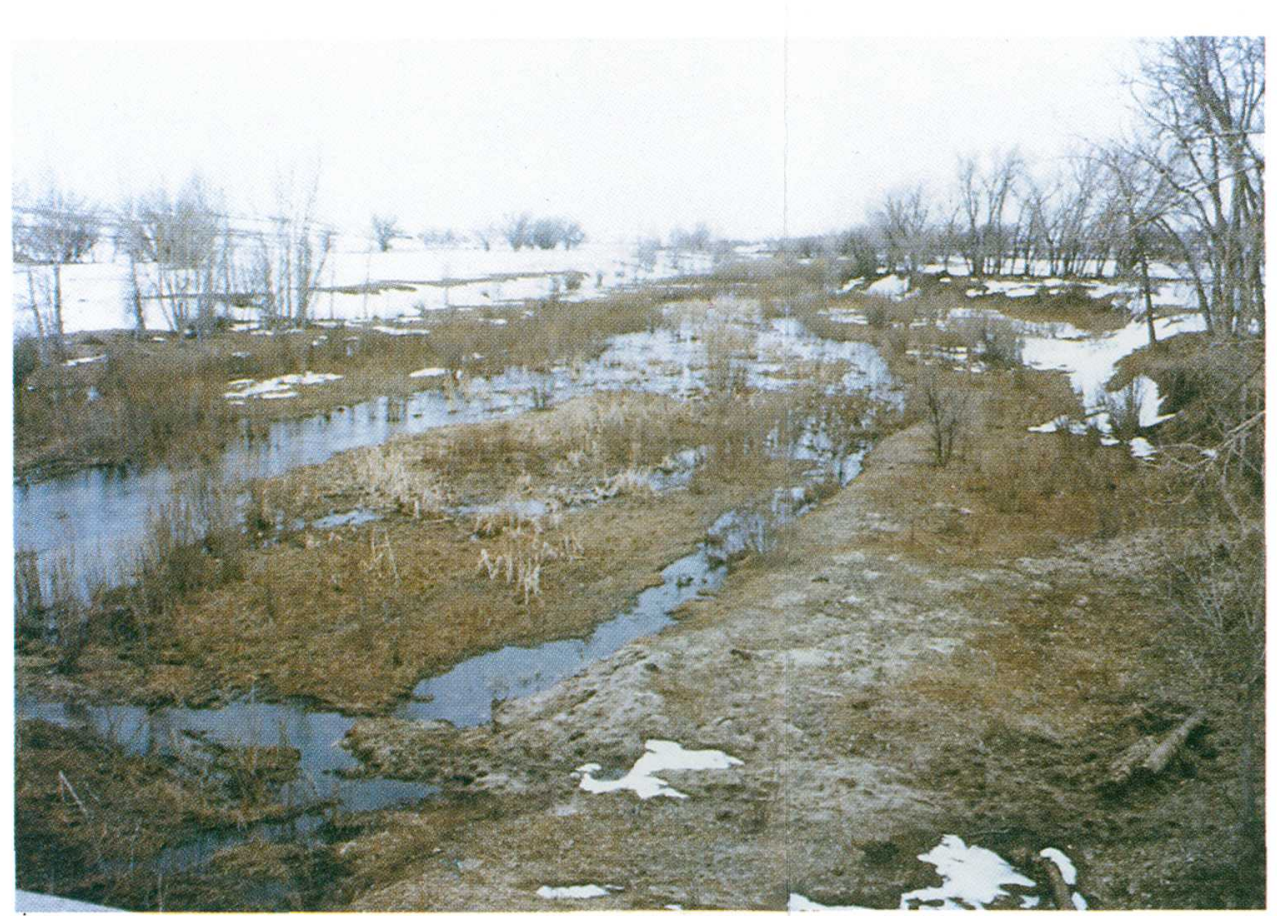

Kiowa Creek, at Kiowa, Colorado, near station 196. 


\title{
9.0 GROUND WATER \\ 9.1 Introduction
}

\section{Ground Water Used Since the Early 1800's}

\author{
Water level and water quality data were collected from wells in the \\ Laramie-Fox Hills, Arapahoe, Denver, and Dawson aquifers.
}

Use of ground water in Area 59 dates back to the early 1800's (Boyd, 1897 and Kirkham and Ladwig, 1980, p. 35). Many of the wells constructed in the Denver area were artesian or flowing artesian wells. By 1895 , the Denver area had more than 400 flowing wells. By the turn of the century, ground water was depleted to such an extent, that most of the these wells had stopped flowing and pumps had to be installed. Transmountain diversions of surface water from the western slope of the Continental Divide in the 1950's and 1960's helped reduce the demand on ground water in the urban areas. However, the outlying developments and communities continued to rely on ground water. Continued pumping has caused severe water level declines in some areas (Kirkham and Ladwig, 1980 , p. 35).

Many sources of ground water occur in Area 59, ranging from low yield aquifers in fractured rocks in the western mountains of the area, to high yield alluvial aquifers in the plains, used mostly for irrigation. Four major bedrock aquifers will be studied in this report: The Laramie-Fox Hills, Arapahoe, Denver, and Dawson aquifers. The location of wells from which water-level and waterquality data have been collected for use in sections 9.3.1, 9.3.2, and 10.1-10.4, are shown in figure
9.1-1 and figure 9.1-2. Further information on these wells can be found in Major and others (1983).

Ground-water levels in approximately 300 wells in some aquifers in Colorado and Wyoming, are measured periodically (once each year if possible) by the U.S. Geological Survey. In Colorado, the wells are measured in cooperation with local water districts and other agencies, and in Wyoming, in cooperation with the Wyoming State Engineer and the City of Cheyenne, Wyo. Some of these wells have been measured for more than 50 years.

Information regarding these wells can be found in (Ragsdale, 1982) and by contacting the following offices:

U.S. Geological Survey

Colorado District Office

Denver Federal Center, MS 415

Lakewood, CO 80225

U.S. Geological Survey

Wyoming District Office

P. O. Box 1125

Cheyenne, WY 82003 
WATER WELL WHERE WATER-LEVEL DATA

- Dawson aquifer

- Denver aquifer

Arapahoe aquifer

- Laramie-Fox Hills aquifer

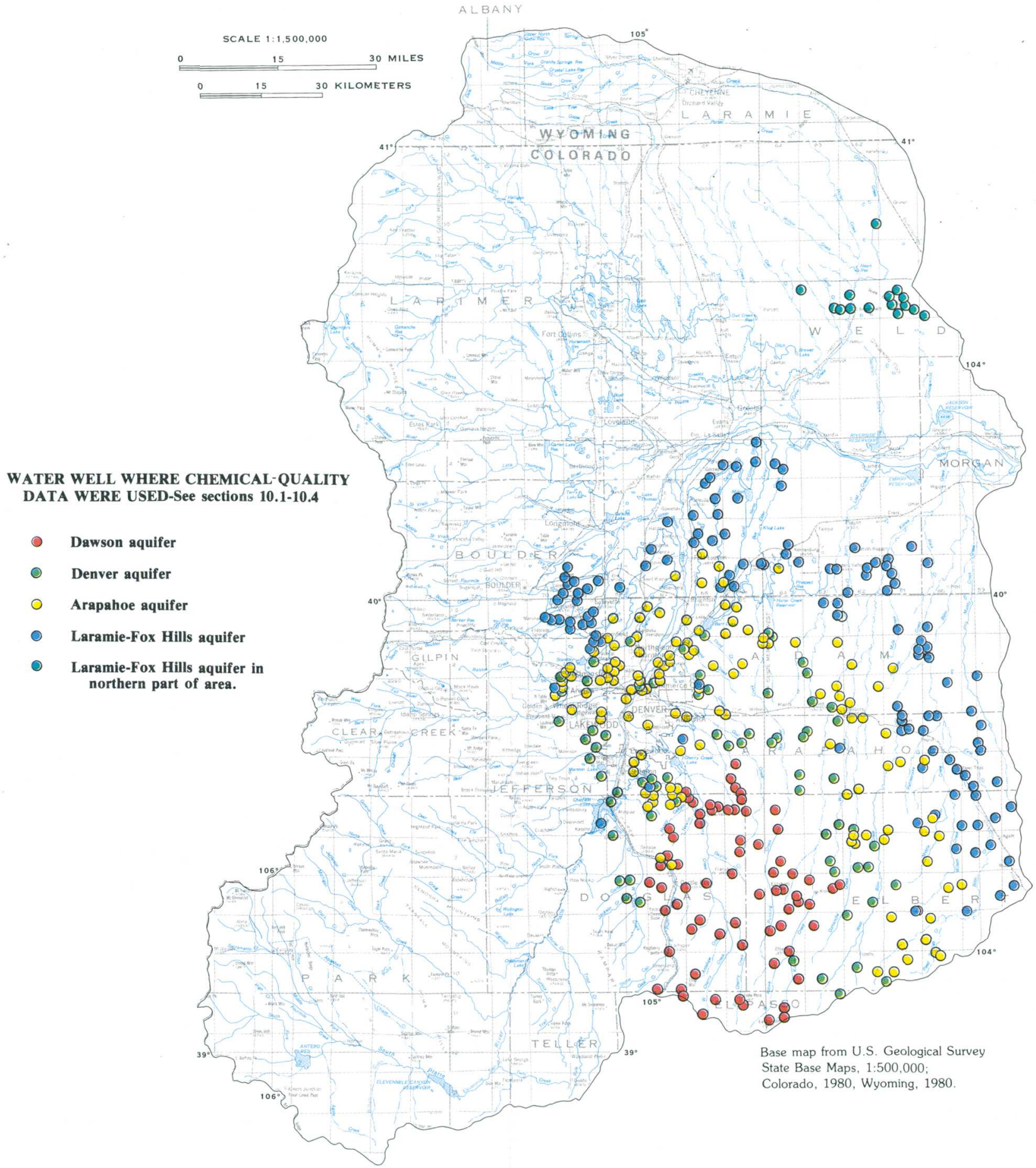

Figure 9.1-2 Location of wells from which water samples for chemical analyses were taken 


\title{
9.0 GROUND WATER--Continued \\ 9.2 Availability
}

\section{Ground Water is Available Throughout Area}

\author{
Well yields range from less than 15 gallons per minute in the mountains \\ to more than 1,000 gallons per minute in the stream valleys of the \\ plains, exceeding 2,000 gallons per minute in some places.
}

Ground water is an important resource, whose availability will influence future growth. It is used throughout Area 59 for irrigation, municipal and industrial water supplies, livestock, and individual residences. In 1974, 90 percent of the ground water used was by agriculture (Colorado Land Use Commission, 1974 , sheet 1). Areas of yields from water wells registered with the Colorado Division of Water Resources through 1974 are shown in figure 9.2-1. The five ranges of well yields (identified by colors in figure 9.2-1) extend from less than 15 gallons per minute to more than 1,000 gallons per minute. These areas of well yields indicate the potential for the underlying aquifer or aquifers to yield water to wells.

Ground water is available in alluvial aquifers of stream valleys, in sedimentary bedrock aquifers of the plains and South Park, and in fracture systems of the metamorphic and granite rocks of the Front Range. In some cases, the well-yield areas in figure 9.2-1 match the locations of an aquifer, or a type of land use. Such is the case in the well-yield area east and south of Greeley, Colo. (fig. 9.2-1), which contains wells with yields of more than 1,000 gallons per minute. This area also corresponds to the alluvial valley-fill aquifer, and an area dominated by irrigated agriculture. Smith and others (1964, pl. 1 and p. 54), reported yields of more than 2,000 gallons per minute from the valley-fill aquifer.

Well yields in the eastern part of Area 59 are generally in the highest range (more than 1,000 gallons per minute), or in the lowest range (less than 15 gallons per minute) (fig. 9.2-1). High-yield wells are probably irrigation wells drawing water from alluvial aquifers of large stream valleys. Low-yield wells are probably wells used for livestock or individual residences, and draw the water from sedimentary bedrock aquifers or alluvial aquifers of small streams.

Intermediate well yields (from 15 to 1,000 gallons per minute) are predominant near the Front Range, north and south from Denver, Colo. Water for most wells in this area is taken from sedimentary bedrock aquifers; water for the remaining wells is taken from alluvial aquifers in the stream valleys. Large intermediate wellyield areas indicate large numbers of wells that are used for municipal, industrial, and domestic water supplies; these large numbers of wells reflect the rapid development of towns and cities along the Front Range (Colorado Land Use Commission, 1974).

In the mountains of the Front Range, most water wells draw water from fractured metamorphic and granite rock, and have well yields of 15 gallons per minute or less (fig. 9.1-1). Some of the lowest well yields in Area 59 are found here. For example, Hall and others (1981, p. 6) list well yields for 68 domestic wells in three mountain communities in western Jefferson County, Colo; these well yields ranged from 0.1 gallons per minute to 15 gallons per minute. Elsewhere in the mountains, small, isolated areas of higher well yields occur. The greatest yields of these wells are located in Jefferson and Park Counties, Colo.; these wells yield from 200 to 1,000 gallons per minute.

Further information about well yields and groundwater availability can be found in the references, section 13.2 , or at the following locations:

U.S. Geological Survey

Colorado District Office

Denver Federal Center, MS 415

Lakewood, CO 80225

U.S. Geological Survey

Wyoming District Office

P. O. Box 1125

Cheyenne, WY 82003

Colorado Land Use Commission

1313 Sherman Street

Denver, CO 80203 


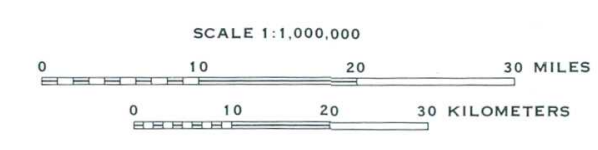

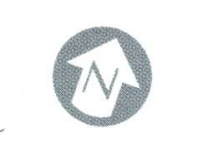

EXPLANATION

AREAS OF WATER YIELD FROM

REGISTERED WELLS

$\square$ MORE THAN 1000 GALLONS PER MINUTE

200 TO 1000 GALLONS PER MINUTE

50 TO 200 GALLONS PER MINUTE

15 TO 50 GALLONS PER MINUTE

LESS THAN 15 GALLONS PER MINUTE

C. Alluvial Aquifer

Modified from Colorado Land Use Commission, 1974, sheet 1

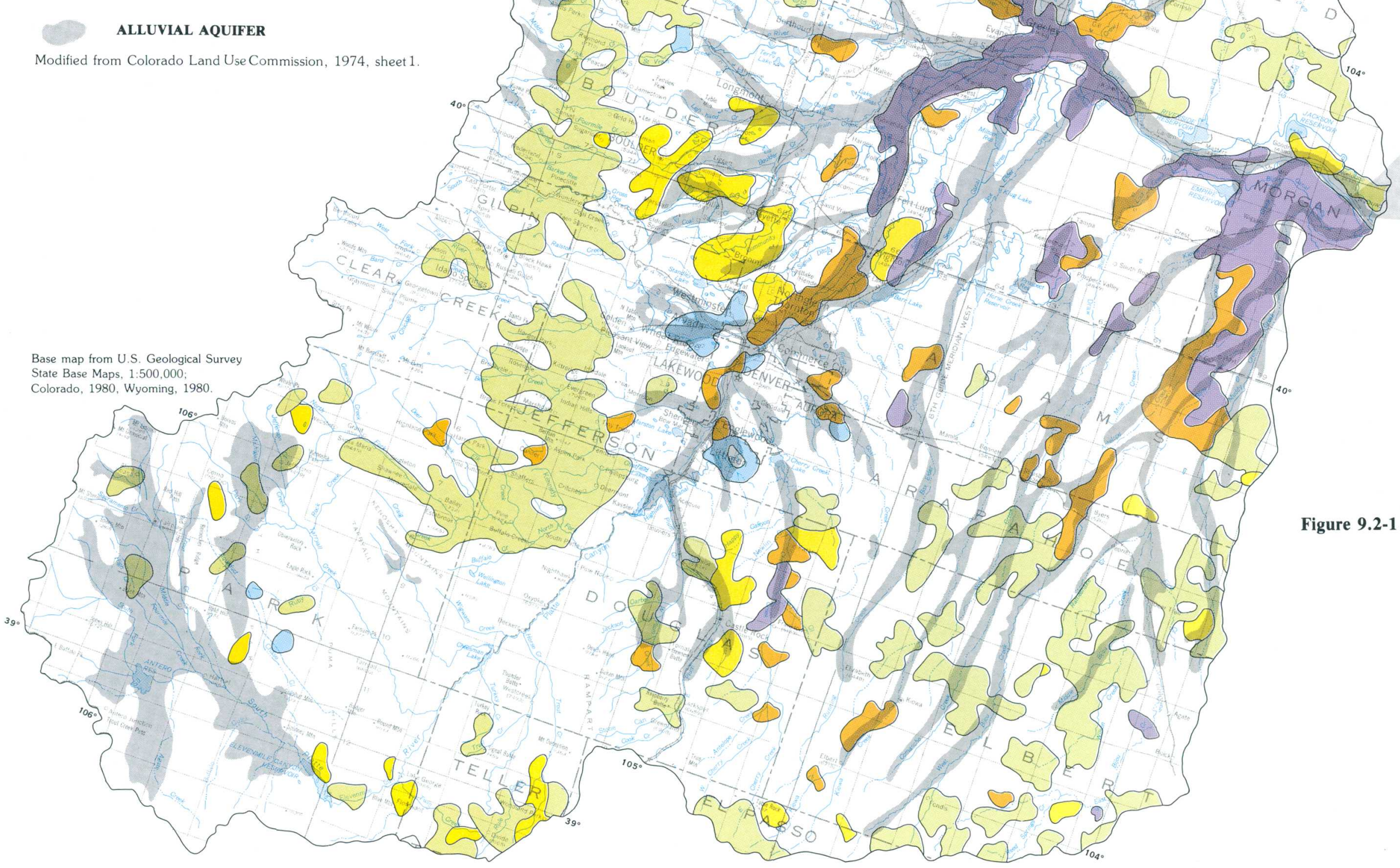




\title{
9.0 GROUND WATER--Continued \\ 9.3 Aquifers
}

9.3.1 Laramie-Fox Hills and Arapahoe

\section{Ground Water Flows Generally Toward the South Platte Valley}

\author{
Ground water in the aquifer south of the South Platte River flows generally \\ from the main recharge areas on the west and south to the main \\ discharge areas on the north and east margins. North of \\ the South Platte River, flow is generally to the southeast.
}

The Laramie-Fox Hills and Arapahoe aquifers are stratigraphically the lowest of the four major bedrock aquifers in Area 59. South of the South Platte River, ground water in these two aquifers flows from the major recharge areas on the west and south to the north and eastern margins of the aquifers (figs. 9.3.1-1 and 9.3.1-2). As can be seen in figure 9.3.1-1, the LaramieFox Hills aquifer is the only major Upper Cretaceous aquifer that extends north of the South Platte River. The direction of flow in this area is generally to the southeast.

The potentiometric surface map (fig. 9.3.1-1) shows the altitude of the static water level during 1978 in the wells completed in the Laramie-Fox Hills aquifer (for approximate locations of the wells measured in 1978, see fig. 9.1-1). Altitude of the water surface in the part of the aquifer south of the South Platte River is higher in the southern part of the aquifer than it is in the northern part, so that the ground water flows generally to the north. The arrows show the direction of flow, which is at right angles to the potentiometric surface contours. As can be seen, some local variation occurs to the general ground-water flow. The most complex area is near Boulder, Colo., where local faulting has vertically shifted segments of the aquifer. North of Denver, Colo. (fig. 9.3.1-1), a major trough occurs in the potentiometric surface, running northeast to near the edge of the aquifer. This trough, caused by extensive pumping in the area, has expanded and deepened in the last 20 years (Robson and others, 1981).

South of the South Platte River, the Laramie-Fox Hills aquifer consists of the Fox Hills Sandstone and the lower part of the Laramie Formation. The upper part of the Laramie Formation is mostly shale with coal and lignite beds (Kirkham and Ladwig, 1980, p. 45).

North of the South Platte River the Laramie Formation has been found to have clay and coal beds at the lower part of the formation and major water-bearing sands in the upper part of the formation, which implies that the Laramie aquifer is cut off from the underlying Fox Hills aquifer. However, the data are not complete enough to justify treating these formations as separate aquifers. Also, the broken line in figure 9.3.1-1 marks the bottom edge of the Fox Hills Sandstone but not necessarily the bottom of the aquifer, because the waterbearing sandstones near the top of the underlying Pierre Shale may be a continuation of the aquifer. Further study is needed to define the upper and lower limits of this aquifer (Paul Schneider, Jr., U.S. Geological Survey, oral commun., 1983).

In the Arapahoe aquifer, most of the water flows laterally through sandstone and conglomerate from areas of recharge at the western edge and the southcentral part of the aquifer to areas of discharge at the northeast and eastern edges of the aquifer (figs. 9.3.1-2 and 9.3.1-3). Some recharge and discharge occurs throughout the aquifer. For example, some recharge comes from rainfall onto the outcrops of the aquifer (near its edges) and from seepage from the overlying Denver aquifer. Also, some discharge occurs to stream alluvium at the top of the aquifer and to the underlying LaramieFox Hills aquifer through the clayey upper part of the Laramie Formation (fig. 9.3.1-2). A major area of discharge, shown as a trough in the potentiometric surface is apparent north of Denver, Colo. (fig. 9.3.1-3). This trough was formed by natural discharge of ground water flowing into the alluvial deposits of the South Platte River and its tributaries. After about 100 years of pumping from the aquifer, however, the trough has grown wider and deeper until ground water flowing into it is now discharged through pumping wells rather than through natural discharge (Robson and others, 1981). More detailed information on the Laramie-Fox Hills and Arapahoe aquifers can be found in Robson and others, (1981), Robson, Romero, and Zawistowski, (1981), and Major and others, (1983). 


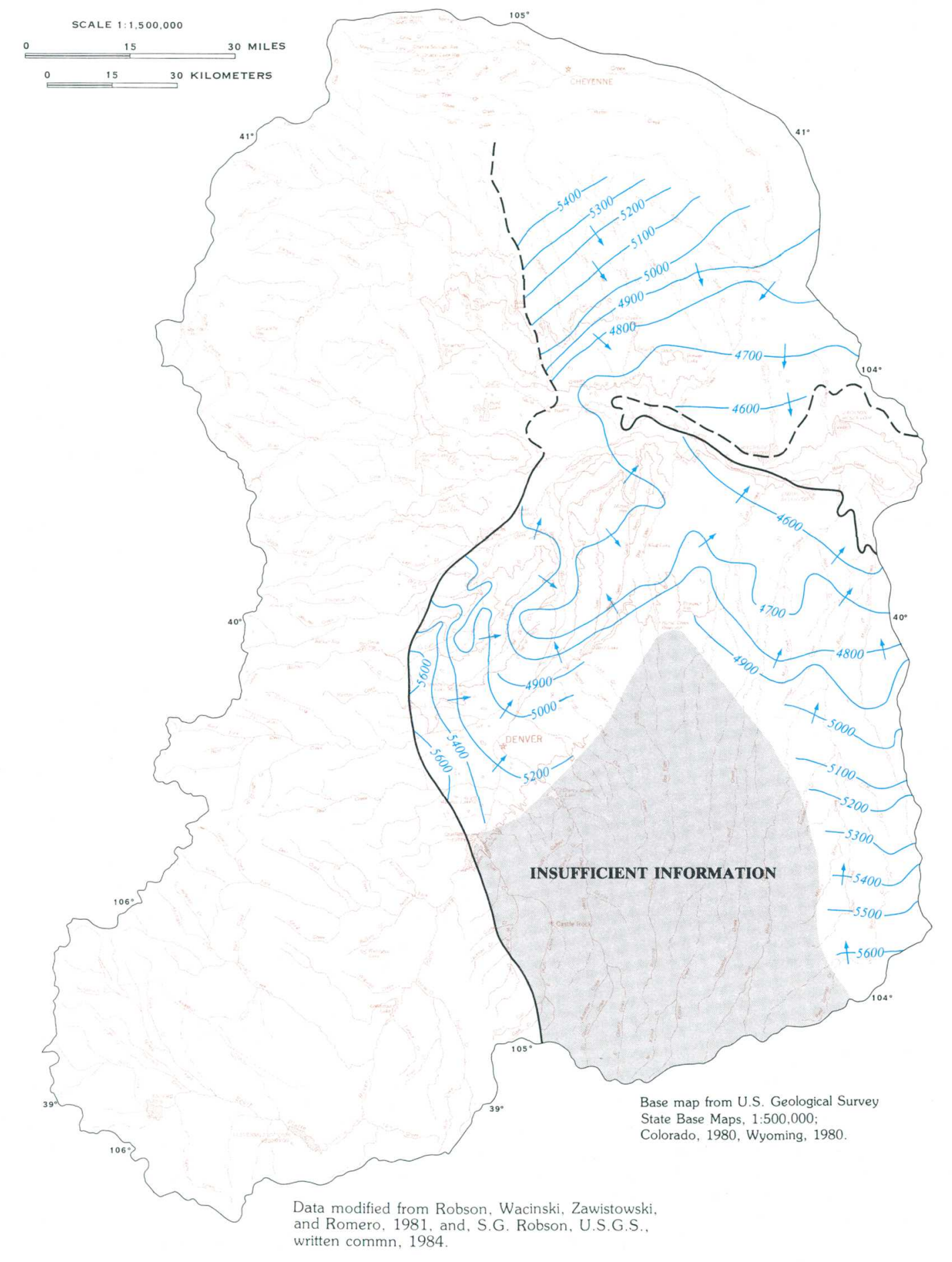

Figure 9.3.1-1 Potentiometric surface and direction of ground-water flow in the Laramie-Fox Hills Aquifer.
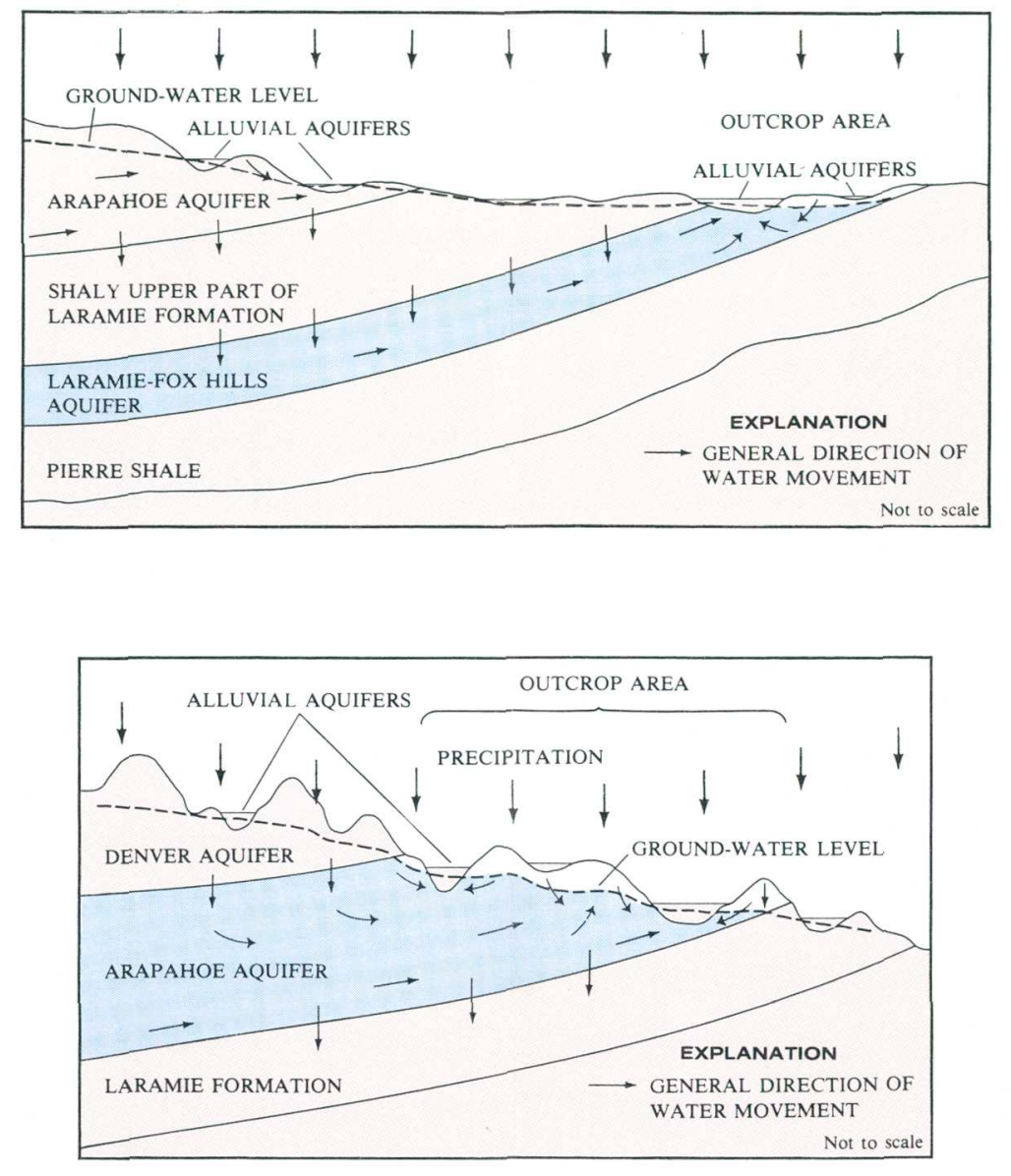

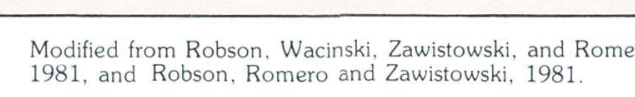

Figure 9.3.1-2 Ground-water movement through the LaramieFox Hills and Arapahoe Aquifers.

\section{EXPLANATION}

POTENTIOMETRIC SURFACE CONTOUR Cortour interval is variable. Potentiometric
surface in feet above sea level. Arrow indicates direction of ground-water flow. APPROXIMATE LIMIT OF AQUIFER

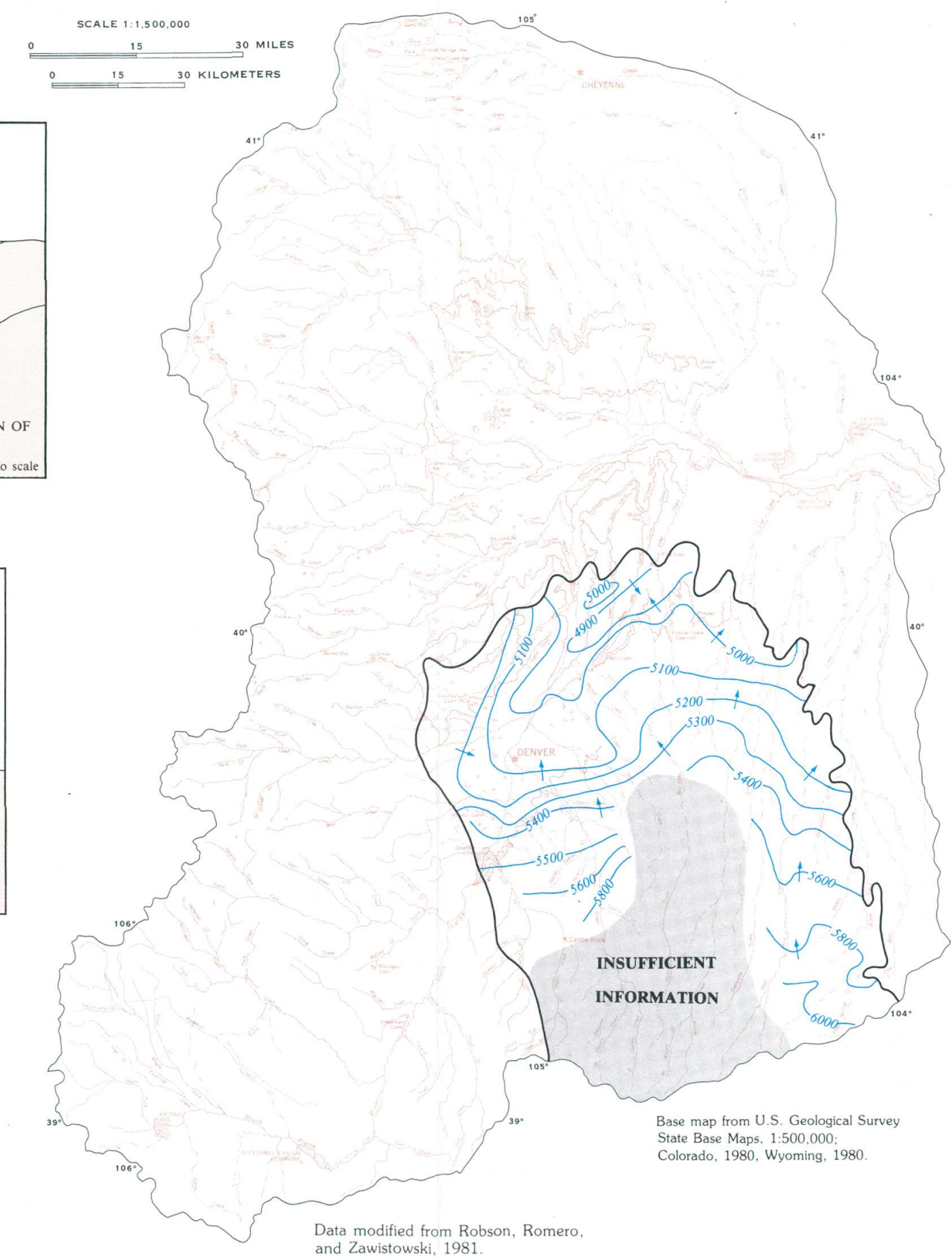

Figure 9.3.1-3 Potentiometric surface and direction of ground-water flow in the Arapahoe Aquifer 


\title{
9.0 GROUND WATER--Continued \\ 9.3 Aquifers--Continued \\ 9.3.2 Denver and Dawson
}

\section{Ground-Water Flow is Generally to the North}

\author{
Some water from the aquifers seeps into many of the streams in the area either \\ directly by springflow, or indirectly by seepage into the stream alluvium.
}

\begin{abstract}
The Denver and Dawson aquifers are stratigraphically the topmost of the four major sedimentary bedrock aquifers in Area 59. They are a major source of ground water, in and southeast of, the Denver, Colo., metropolitan area. Generally, the Dawson aquifer, covering the smaller area of the two, has water of better quality, and well yields that are higher than the Denver aquifer (Robson and Romero, 1981a and 1981b). The direction of ground-water flow in these aquifers (figs. 9.3.2-1, 9.3.2-2, and 9.3.2-3), while showing some local variations, is generally to the northeast.
\end{abstract}

The Denver aquifer (fig. 9.3.2-1) extends from the Denver, Colo., metropolitan area south to beyond the border of Area 59. The south center of the aquifer is also its deepest part which is penetrated by few wells. In this area few data are available for constructing a potentiometric surface map (fig. 9.3.2-1). Denver aquifer wells generally yield less water than wells in the Dawson aquifer. Most of the water is found in lenticular sandstone beds, which, in rare cases, are as much as 50 feet thick, in the lower part of the aquifer. The upper part of the aquifer, which contains fewer sandstone lenses, locally may yield some water, but is much less productive than the lower part (Kirkham and Ladwig, 1980, p. 41). The Denver aquifer is also one of the two formations in Area 59 that contains coal deposits (a low-grade coal called lignite), that are thick and extensive enough to have been mined in the past; no lignite is being mined now. Lignite deposits are sealed off in a correctly constructed water well, so that there is no direct contamination from water in these deposits.

The potentiometric surface contours in figure 9.3.2-1 indicate the altitude of the static water levels measured in 1978 in wells completed in the Denver aquifer (these observation wells are shown in fig. 9.1-1). The highest water levels are found in the southern part of the aquifer and the lowest water levels are found northeast of Denver, Colo., near the northern boundary of the aquifer. Because water flows down the potentiometric gradient at right angles to the contours, the ground water flow in the Denver aquifer is generally to the northeast (fig. 9.3.2-1). The ground water is flowing from recharge areas to discharge areas. The recharge areas are along the western margin of the aquifer, where the aquifer forms almost vertical rock outcrops, and along the southern boundary of Area 59 (the Palmer Ridge). The discharge areas are located along the northeastern and eastern boundary of the aquifer and in stream valleys that are below the ground-water level in the Denver aquifer (fig. 9.3.2-2). Most of the discharge at the margin of the aquifer is into alluvium either by seepage or by spring flow from an outcrop of the aquifer. A small part of the discharge from the Denver aquifer goes into the underlying Arapahoe aquifer (fig. 9.3.2-2).

The Dawson aquifer is the uppermost of the four major aquifers. It contains numerous thick sandstones and conglomerates that yield water to more than 3,600 wells (Robson and Romero, 1981a, sheet 1), primarily for drinking water and livestock. The aquifer underlies an area of about 1,200 square miles southeast of Denver, Colo. (Robson and Romero, 1981a, sheet 1), extending south of the boundary of Area 59. The southern boundary of Area 59 is also the approximate location of the ground-water divide for the Dawson aquifer. Ground water north of the divide moves north into Area 59, and ground water south of the divide moves south, away from Area 59. According to Robson and Romero (1981a, sheet 2) the Dawson aquifer is recharged by rainfall seeping through the highland areas between the stream valleys. Most water in the aquifer flows laterally from recharge areas to discharge areas. This water can take two routes: (1) A local recharge-discharge route from highland areas to nearby stream valleys; and (2) a regional recharge-discharge route where rainwater moves deeper into the aquifer and discharges to a distant stream valley.

The potentiometric contours (fig. 9.3.2-3) indicate that the altitudes of standing water levels in wells in the Dawson aquifer are highest in the southern margin of the aquifer and lowest in the northern tip of the aquifer; the general direction of ground-water flow is to the north. Sharp bends in the potentiometric contours are most evident along Plum Creek, Cherry Creek, and Kiowa Creek, indicating discharge into these stream valleys.

Other bedrock and alluvial aquifers are used as sources for ground water in Area 59. Limited information is available for these aquifers in publications listed in the reference section (12.2) or by contacting the following offices:

\footnotetext{
U.S. Geological Survey

Colorado District Office

Denver Federal Center, MS 415

Lakewood, CO 80225

U.S. Geological Survey

Wyoming District Office

P. O. Box 1125

Cheyenne, WY 82003
} 


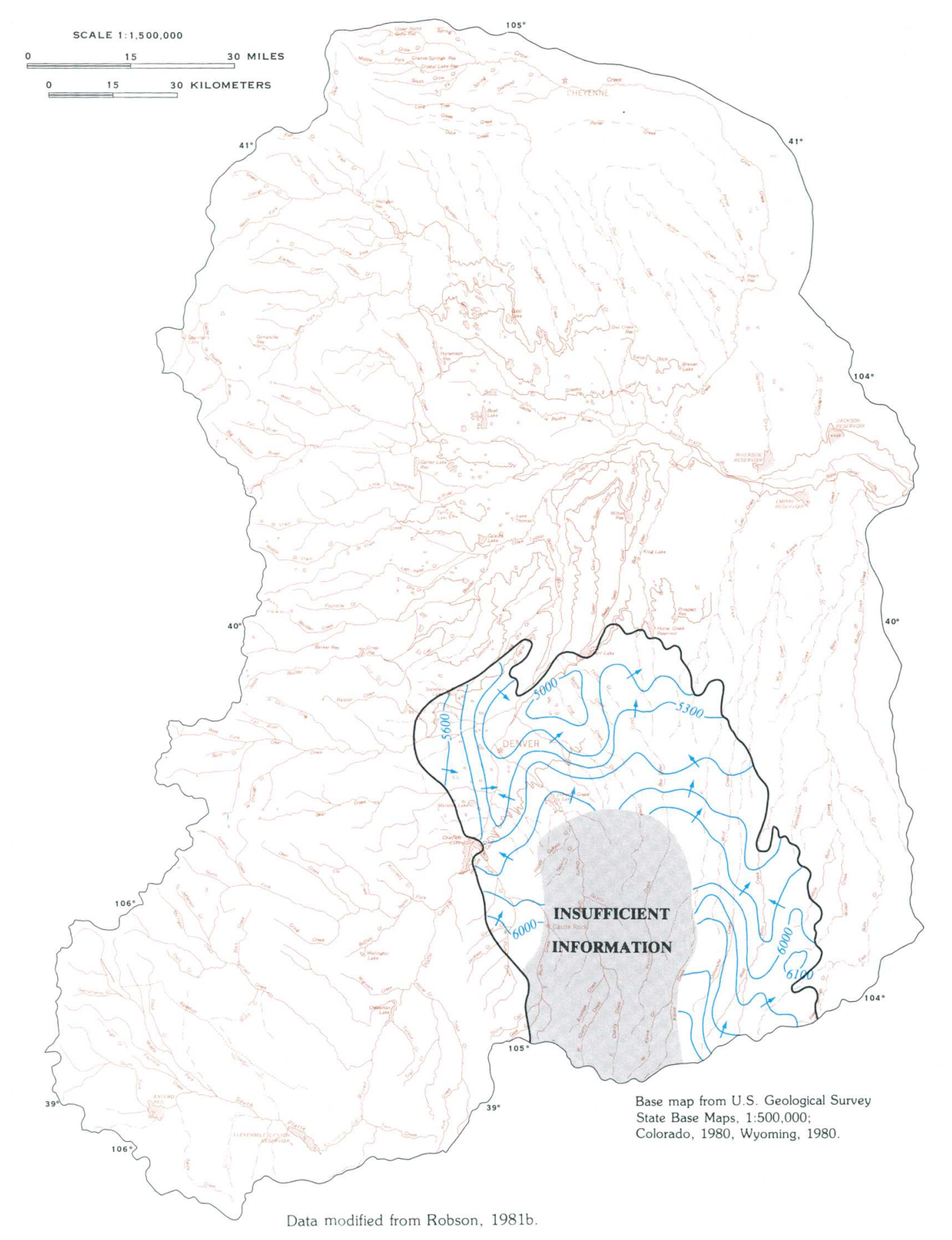

Figure 9.3.2-1 Potentiometric surface and direction of ground-water flow in the Denver aquifer.
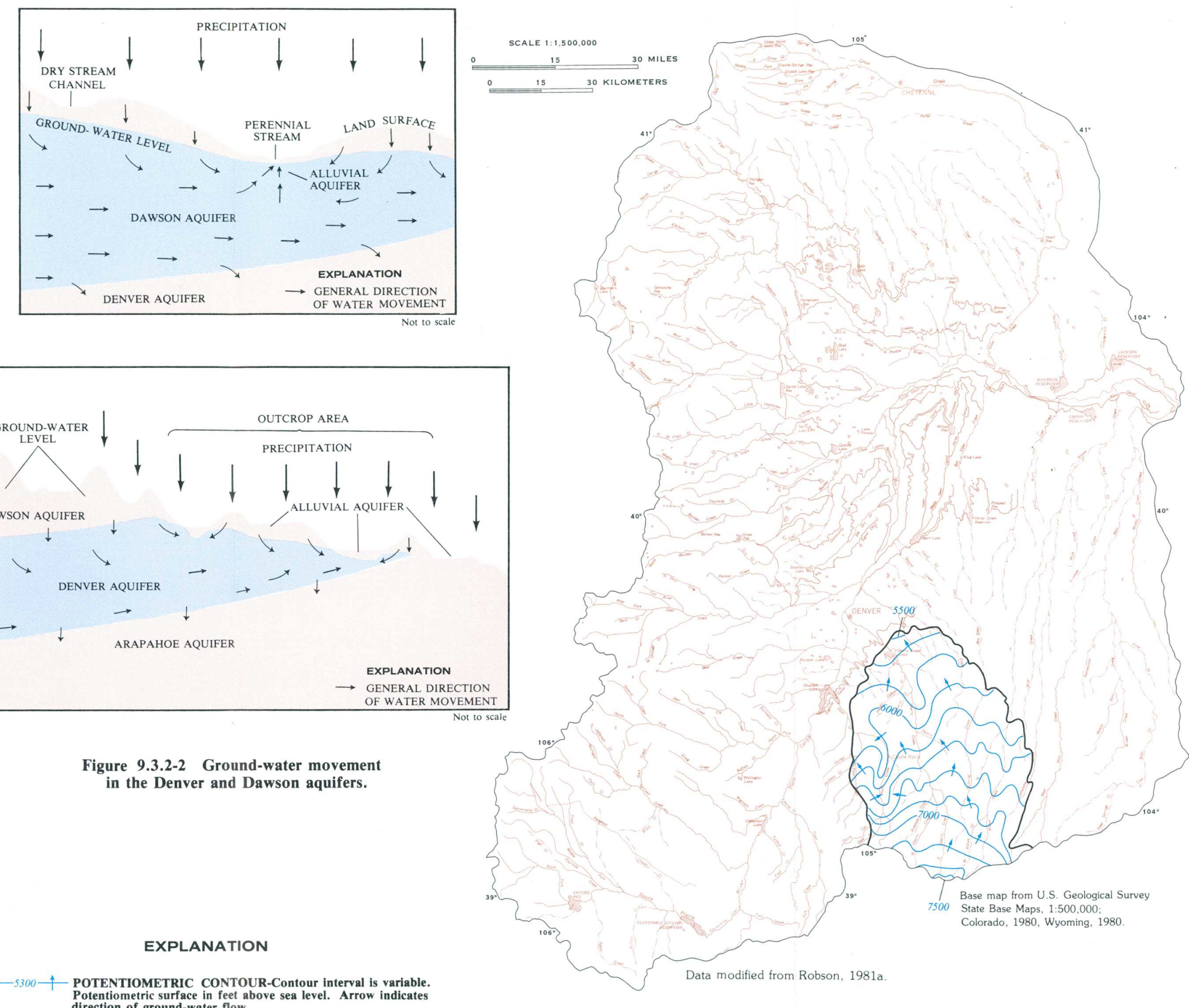
Figure 9.3.2-3 Potentiometric surface and direction 


\title{
10.0 GROUND-WATER QUALITY \\ 10.1 Laramie-Fox Hills Aquifer
}

\section{Water Quality in the Aquifer is Highly Variable}

\author{
Water in the south-central part of the aquifer is generally good quality; \\ in many other places in the aquifer, methane and hydrogen-sulfide \\ gases make the water unsuitable for most uses.
}

The Upper Cretaceous Laramie Formation and the underlying Fox Hills Sandstone are hydraulically connected throughout most of the Denver basin (fig. 10.1-1). This rock unit is referred to as the Laramie-Fox Hills aquifer, and is in the lowest stratigraphic position of the four major aquifers considered here. A study by Robson and others (1981) on the Laramie-Fox Hills aquifer, south of the South Platte River, has been used extensively for the data and conclusions in this report.

Generally, water quality in the Laramie-Fox Hills aquifer is suitable for domestic use. In some areas near the edges of the aquifer in the south, and in scattered areas north of the South Platte River, the chemical quality of the water is poorer than the rest of the area, indicated by the higher dissolved-solids concentrations (fig. 10.1-1); this water may not be acceptable for most uses.

The Laramie-Fox Hills aquifer south of the South Platte River contains dissolved-solids concentrations ranging from less than 200 milligrams per liter north and east of Denver, Colo., to more than 2,000 milligrams per liter (or slightly saline) (Hem, 1970, p. 219), in areas northeast of Boulder, Colo. The area northeast of Boulder, Colo. is the location of the abandoned BoulderWeld coal field, where underground mines were dug into the Laramie coal deposits.

Water in the Laramie-Fox Hills aquifer south of the South Platte River is predominantly sodium-bicarbonate water. In a few areas, near the edges of the aquifer, sodium sulfate water is found, where sodium and sulfate ions predominate in the ground water; therefore this ground water is classified as sodium-sulfate type water.

Dissolved-solids concentrations, south of the South Platte River in figure 10.1-1 can be used to find approximate concentrations of the chemical constituents shown in the two graphs in figure 10.1-2. For sulfate-type water (the shaded areas in fig. 10.1-1), use the sulfate-type water graph to get approximate concentrations for sulfate, chloride, sodium, bicarbonate, alkalinity, and potassium, by following the example of the dotted line shown on the graph. For bicarbonate-type water, the other graph is used in the same way to get approximate concentrations for bicarbonate, alkalinity, fluoride, sodium, and chloride.

For the area north of the South Platte River, limited water-quality data are available from Repplier and others (1981); these authors collected water samples from the upper part of the Laramie-Fox Hills aquifer and the lower part of the Laramie-Fox Hills aquifer in northeast Weld County, Colo. as part of a state-wide reconnaissance of ground-water quality. Dissolved-solids concentrations for the water in the upper part of the Laramie-Fox Hills aquifer range from less than 300 milligrams per liter to more than 2,000 milligrams per liter (slightly saline); dissolved-solids concentrations for the water in the lower part of the Laramie-Fox Hills aquifer range from less than 600 milligrams per liter to more than 1,000 milligrams per liter. The water is contaminated by dissolved constituents from coal and other mineral deposits in some localized parts of the area (Kirkham and Ladwig, 190, p. 37).

More detailed information on the water quality of the Laramie-Fox Hills aquifer is available in Robson and others, 1981; Kirkham and Ladwig, 1980; Major and others, 1983; and McConaghy and others, 1964. Section 13.2 also lists some additional references. Information also can be obtained from the following offices:

U.S. Geological Survey Colorado District Office

Denver Federal Center, MS 415 Lakewood, CO 80225

U.S. Geological Survey Wyoming District Office P. O. Box 1125 Cheyenne, WY 82003

Colorado Department of Natural Resources Office of the State Engineer 1313 Sherman Street Denver, CO 80203 


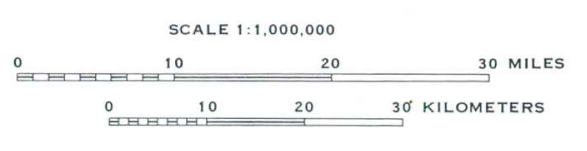

\section{(2)}

EXPLANATION

LINES OF EQUAL DISSOLVED SOLDS CONCENTRATIONS
Interval, in milligrams per liter, is variable

- 800 - LARAMIE-FOX HILLS AQUIFER

Modified from R
and Romero, 191.

- 300 - LARAMIE-FOX HILLS (UPPER PART)

- 600- LARAMIE-FOX HILLS (LOWER PART)

- 2 APPROXIMATE LIMIT OF THE LARAMIE-FOX

is estimated.
See section 9.1 for location of observation wells

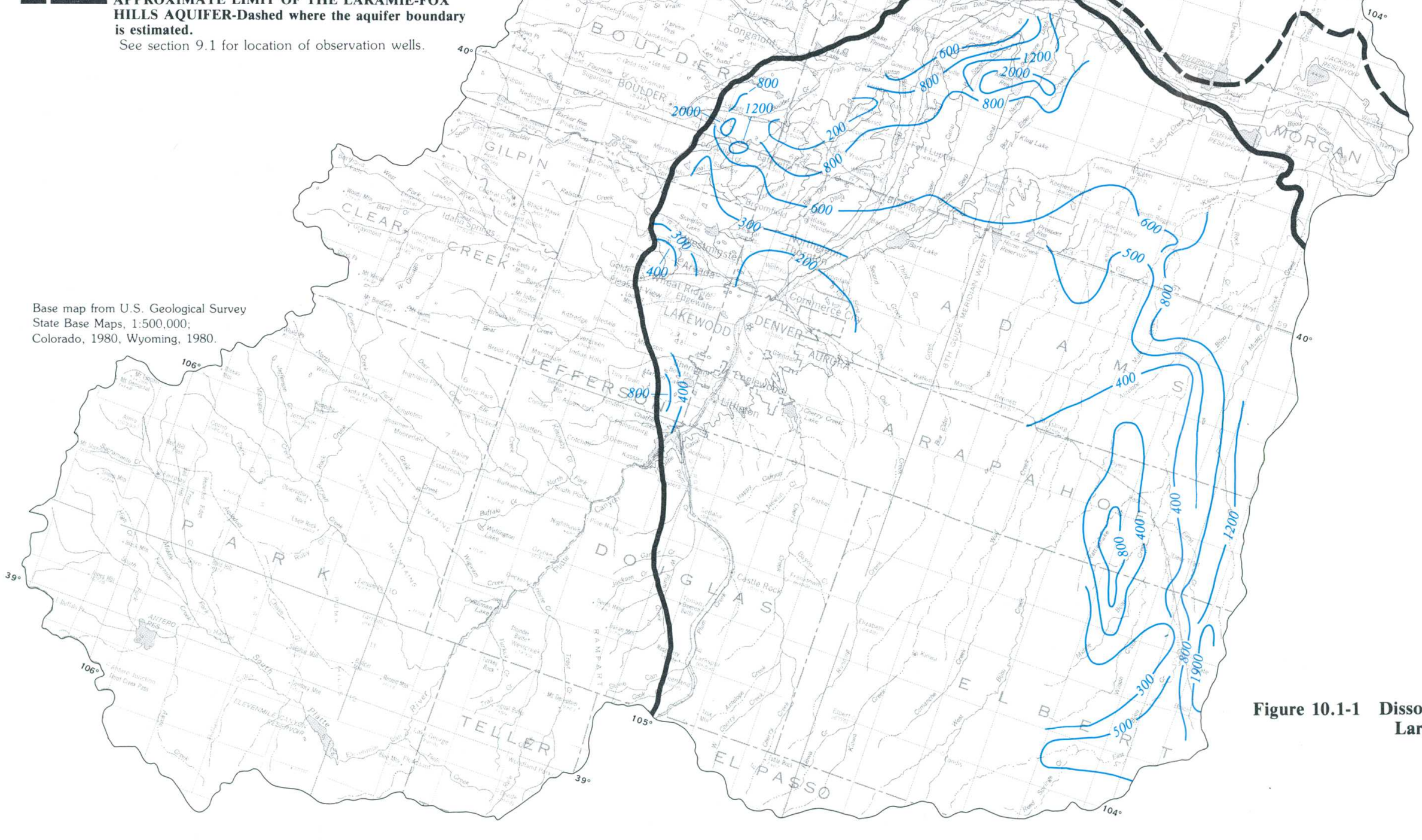

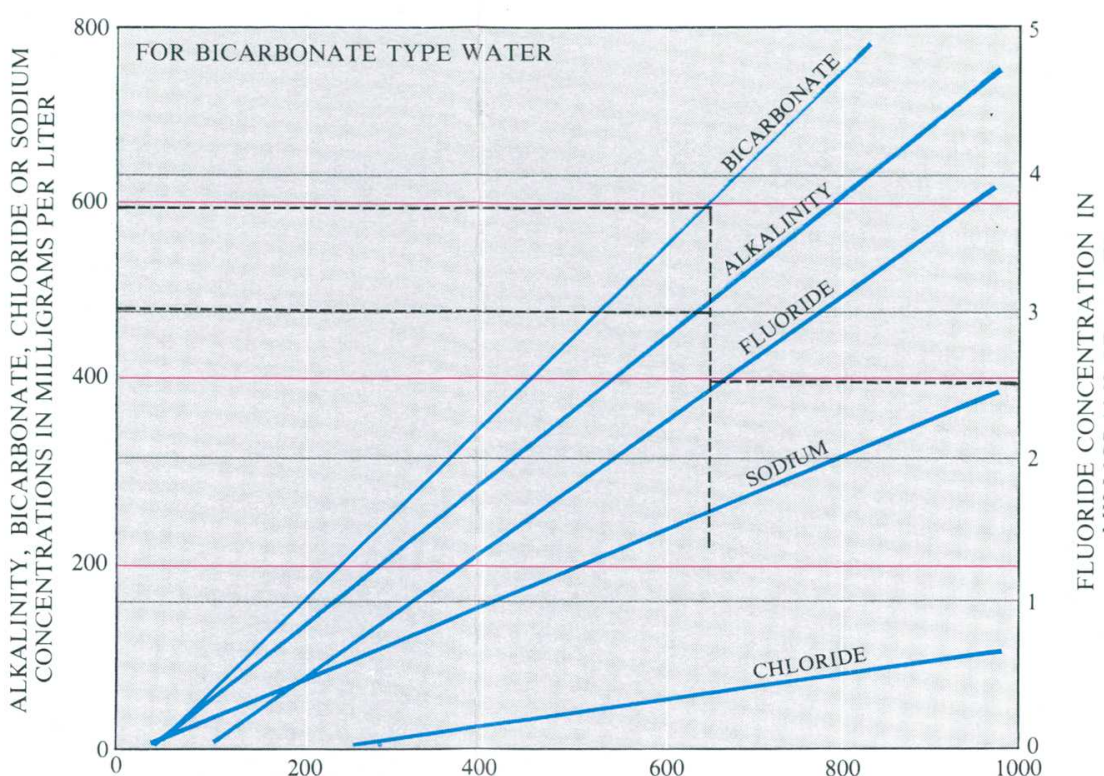

DISSOLVEDSOUDS CONCENTRATON, IN VUUUGR SOMS PER LITER

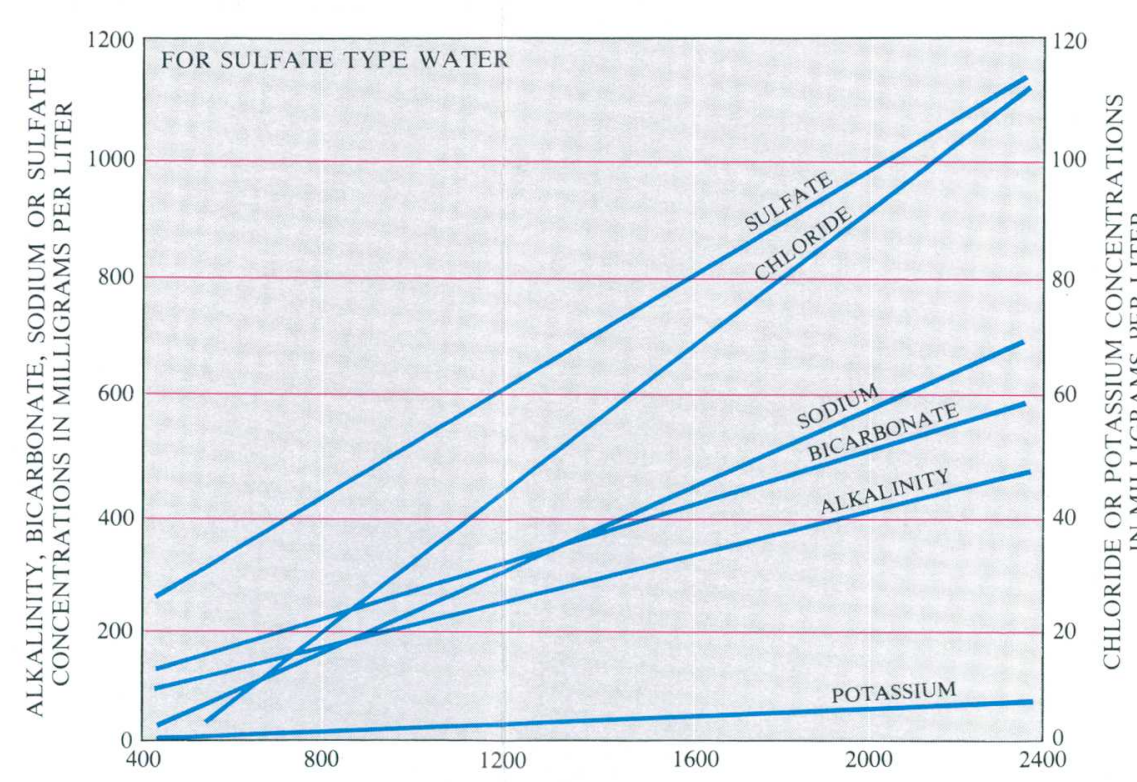

$$
\begin{aligned}
& \text { 10.1-2 Water-quality relations in the Laramie-F } \\
& \text { Hills aquifer, south of the South Platte River. }
\end{aligned}
$$

Hills aquifer, south of the South Platte River. 


\title{
10.0 GROUND-WATER QUALITY--Continued 10.2 Arapahoe Aquifer
}

\section{Arapahoe Aquifer has Good Quality Water}

\author{
Mineral content of the ground water in the Arapahoe aquifer \\ ranges from low near the center of the aquifer to high \\ (slightly saline) near the north and southeast edges.
}

The Arapahoe Formation is a major aquifer in the Denver basin, which contains generally goodquality water. According to Robson, Romero, and Zawistowski (1981), water in the Arapahoe aquifer meets drinking-water standards (Colorado Department of Health, 1979; U.S. Environmental Protection Agency, 1976) for public-water supplies in most of the area. However, in a few areas near the southeast and northern edges of the aquifer, water in the aquifer is of marginal quality (fig. 10.2-1). Unless otherwise stated, water-quality information in this section is from Robson, Romero, and Zawistowski (1981).

Dissolved-solids concentrations in the Arapahoe aquifer decrease near the center of the aquifer and increase near the edges of the aquifer. Dissolved-solids concentrations range from less than 200 milligrams per liter near the center of the aquifer to more than 2,000 milligrams per liter at places near the north and southeast edge of the aquifer (fig. 10.2-1). Concentrations of dissolved solids in the aquifer west of the South Platte River are much higher than concentrations east of the South Platte River.

Most of the water in the Arapahoe aquifer contains predominately sodium and bicarbonate ions; these ions cause this water to be classified as sodium-bicarbonate-type water. Calciumbicarbonate-type water also occurs in some isolated areas south of Sedalia, Colo., in the southwestern part of the aquifer. Sodium-sulfate water occurs at the eastern and western margins of the aquifer.
The graph in figure 10.2-2 shows the relationships between specific conductance (which is a measure of the ability of water to conduct electricity), dissolved-solids concentrations, sulfate concentrations, and sodium-plus-calcium concentrations. By measuring the specific conductance of water from a well, the other three concentrations can be estimated, using the graph as indicated.

Approximate locations of the wells used for the dissolved solids map are shown in figure 9.1-1. For more detailed information see Robson, Romero and Zawistowski (1981). For more complete hydrologic data for the Arapahoe aquifer see Major and others (1983); Hillier and others (1978); and McConaghy and others, 1964) and the following offices:

U.S. Geological Survey

Colorado District Office

Denver Federal Center, MS 415

Lakewood, CO 80225

U.S. Geological Survey

Wyoming District Office

P. O. Box 1125

Cheyenne, WY 82003

Colorado Department of Natural Resources

Office of the State Engineer

1313 Sherman Street

Denver, CO 80203 


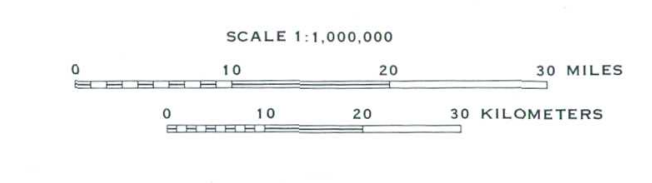

\section{(20)}

EXPLANATION

INE OF EQUAL DISSOLVED-SOLIDS

is variable. See section 9.1 for location of observation wells

APPROXIMATE LIMIT OF THE ARAPAOEE AQUIFER
Modified from Robson, Romero, and Zawistowski, 1981.
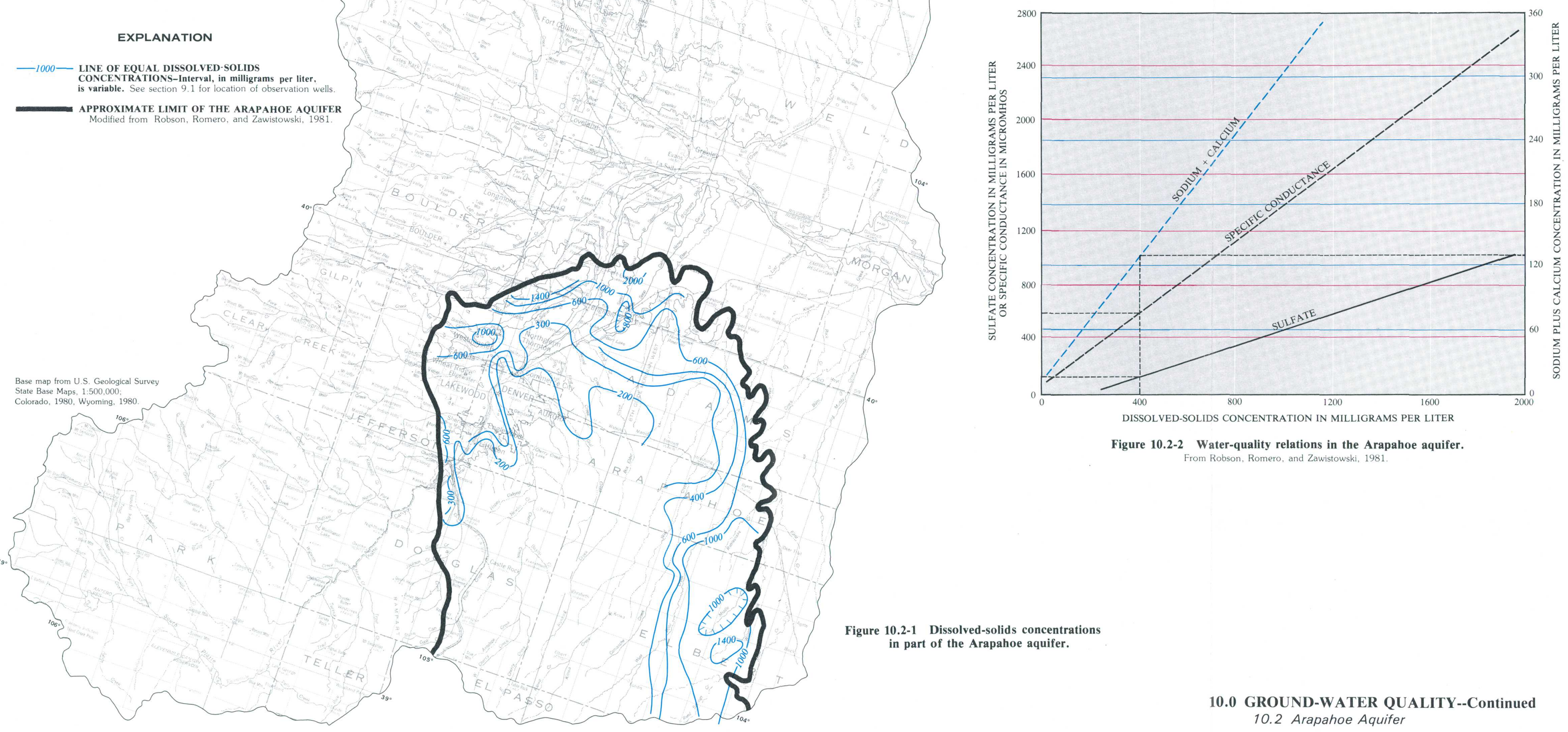


\title{
10.0 GROUND-WATER QUALITY--Continued 10.3 Denver Aquifer
}

\section{Denver Aquifer Contains Mostly Good-Quality Water}

\author{
Best-quality water is near the center of the aquifer.
}

Most of the water in the Denver aquifer contains calcium-bicarbonate type water that meets drinking water standards (Colorado Department of Health, 1979; U.S. Environmental Protection Agency, 1976) for public water supplies. However, a few areas near the margin of the aquifer are more highly mineralized and do not meet these standards (fig. 10.3-1). Robson and Romero (1981b) have studied this aquifer extensively, and, unless otherwise stated, the data and conclusions about the Denver aquifer are from this reference.

Water in the central part of the aquifer contains predominantly calcium and bicarbonate ions, which classifies it as calcium-bicarbonate type water. Near the thinner edges of the aquifer, in the north and southeast, sodium bicarbonate or sodium-sulfate type water is more common. Calcium-bicarbonate type water at the central part of the aquifer probably originates from water in the overlying Dawson aquifer. As the calciumbicarbonate ground water flows through the clay deposits of the Denver aquifer toward the edges of the aquifer, the calcium ion is exchanged for the sodium ion, and sodium-bicarbonate type water is the result. Soluble sulfate minerals at the surface and in the aquifer are probably the source of the sulfate ions in the sodium-sulfate type water.

Water containing dissolved-solids concentrations from 1,000 to 3,000 milligrams per liter is considered by the U.S. Geological Survey to be slightly saline (Hem, 1970, p. 219). Dissolved-solids concentrations in the water in the Denver aquifer ranged from less than 100 milligrams per liter at the southwest part of the aquifer, to more than 1,000 milligrams per liter at two areas near the margin of the aquifer. The least mineralized water is near the center of the aquifer, where recharge occurs from the good-quality water of the Dawson aquifer. Near the edge of the aquifer lignite deposits in the Denver aquifer may contribute to mineralization of ground water because higher concentrations of dissolved oxygen in the ground water promotes dissolution of minerals in this region.

The graphs in figure 10.3-2 are a convenient method of estimating the concentrations of bicarbonate, alkalinity, sodium, sulfate, and chloride when the specific conductance of well water from the Denver aquifer is known. Specific conductance is an easily measured property, that indicates the ability of water to conduct an electric current.

Locations of the observation wells used to sam. ple the Denver aquifer are shown in figure 9.1-2. A more detailed description of the Denver aquifer is given in Robson and Romero, 1981b. Hydrologic data for the Denver aquifer are available in Major and others (1983) and McConaghy and others (1964); and from the following offices:

U.S. Geological Survey

Colorado District Office

Denver Federal Center, MS 415

Lakewood, CO 80225

U.S. Geological Survey

Wyoming District Office

P. O. Box 1125

Cheyenne, WY 82003

Colorado Department of Natural Resources Office of the State Engineer

1313 Sherman Street

Denver, CO 80203 

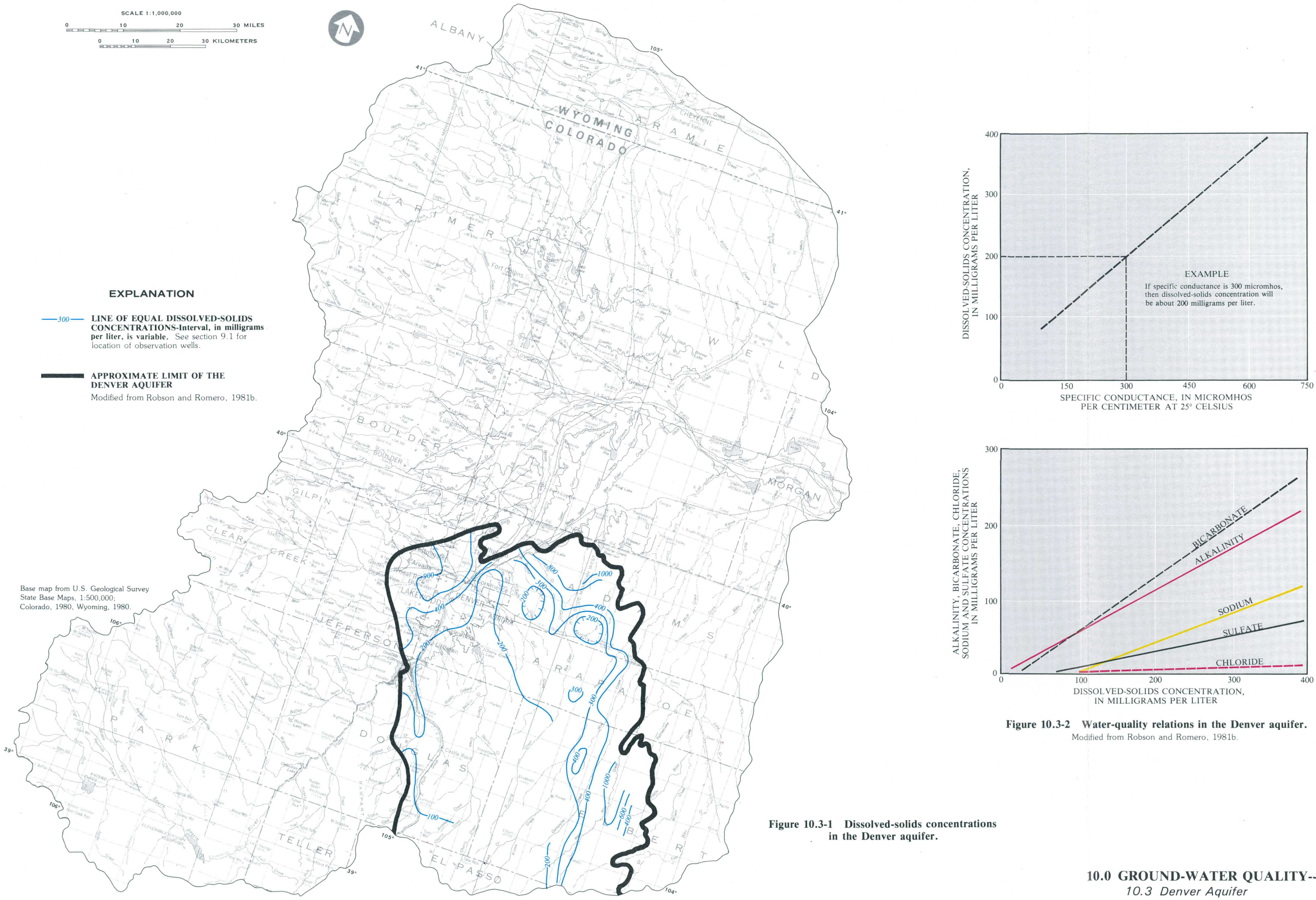

Figure 10.3-1 Dissolved-solids concentrations in the Denver aquifer. 


\title{
10.0 GROUND-WATER QUALITY--Continued \\ 10.4 Dawson Aquifer
}

\section{Dawson Aquifer Contains Excellent Quality Water}

\author{
Water in the Dawson aquifer is low in minerals in the southwestern part \\ of the aquifer; it increases in dissolved mineral content as the water \\ flows toward the northern and eastern edges of the aquifer.
}

The Dawson aquifer is the uppermost major bedrock aquifer in the Denver basin. Water in the Dawson aquifer is generally hard, low in sulfate, and of overall excellent quality, meeting the drinking water standards (Colorado Department of Health, 1979; U.S. Environmental Protection Agency, 1976) and for public water supplies in most of the area (Robson and Romero, 1981a). Some isolated areas have iron concentrations high enough to cause reddish-brown stains on plumbing fixtures. Also, a small area of the aquifer east of Cherry Creek Reservoir contains water that exceeds drinking-water standards for sulfate concentrations and is classified as slightly saline. Robson and Romero (1981a) made a detailed study of the Dawson aquifer; their report will be used as the source of the data and conclusions concerning the Dawson aquifer, unless otherwise indicated.

Water in the Dawson aquifer is predominately calcium-bicarbonate type water. Sodiumbicarbonate and sodium-sulfate type waters are also present, but only in a few isolated areas. The source for calcium and bicarbonate ions is in the rocks of the Dawson aquifer, which are dissolved by the precipitation that percolates through the aquifer.

Concentration of dissolved solids in the Dawson aquifer ranges from less than 100 milligrams per liter in the south-central part of the aquifer, to more than 1,500 milligrams per liter east of Cherry Creek Reservoir (fig. 10.4-1). Water with dissolvedsolids concentrations between 1,000 and 3,000 milligrams per liter is classified as slightly saline (Hem, 1970, p. 219). Only one small area east of
Cherry Creek Reservoir, at the edge of the aquifer, where some deposits of gypsum and related minerals occur, has dissolved-solids concentrations of more than 1,000 milligrams per liter. The smallest concentrations are found near the southwestern part of the aquifer in the Palmer Divide area.

Water in the Palmer divide area has not been in the aquifer as long as water in other parts of the aquifer. As ground water flows toward the northern parts of the aquifer, this water dissolves some of the minerals in the rocks of the aquifer and increases its dissolved-solids concentration. Graphs in figure 10.4-2 can be used to estimate concentrations of bicarbonate alkalinity, potassium, fluoride, and sodium, by knowing the specific conductance of water from a well in the Dawson aquifer.

Locations of wells, from which dissolved-solids data were taken, are shown in figure 9.1-2. For a more detailed description of the water quality of the Dawson aquifer, see Robson and Romero, 1981a. More complete hydrologic data for the Dawson aquifer is available in the following offices:

U.S. Geological Survey

Colorado District Office

Denver Federal Center, MS 415

Lakewood, CO 80225

Colorado Department of Natural Resources

Office of the State Engineer

1313 Sherman Street

Denver, CO 80203 


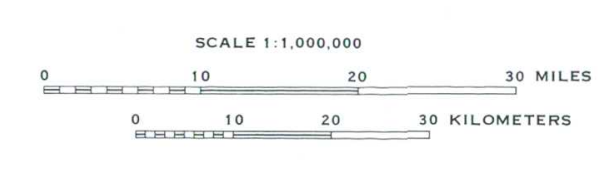

(2)

EXPLANATION

-150- LINE OF EQUAL DISSOLVEDD-SOLIIDS

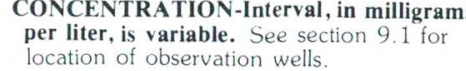

- 2 DPPROXIMATE LIMIT OF THE Modified from Robson and Romero, 19

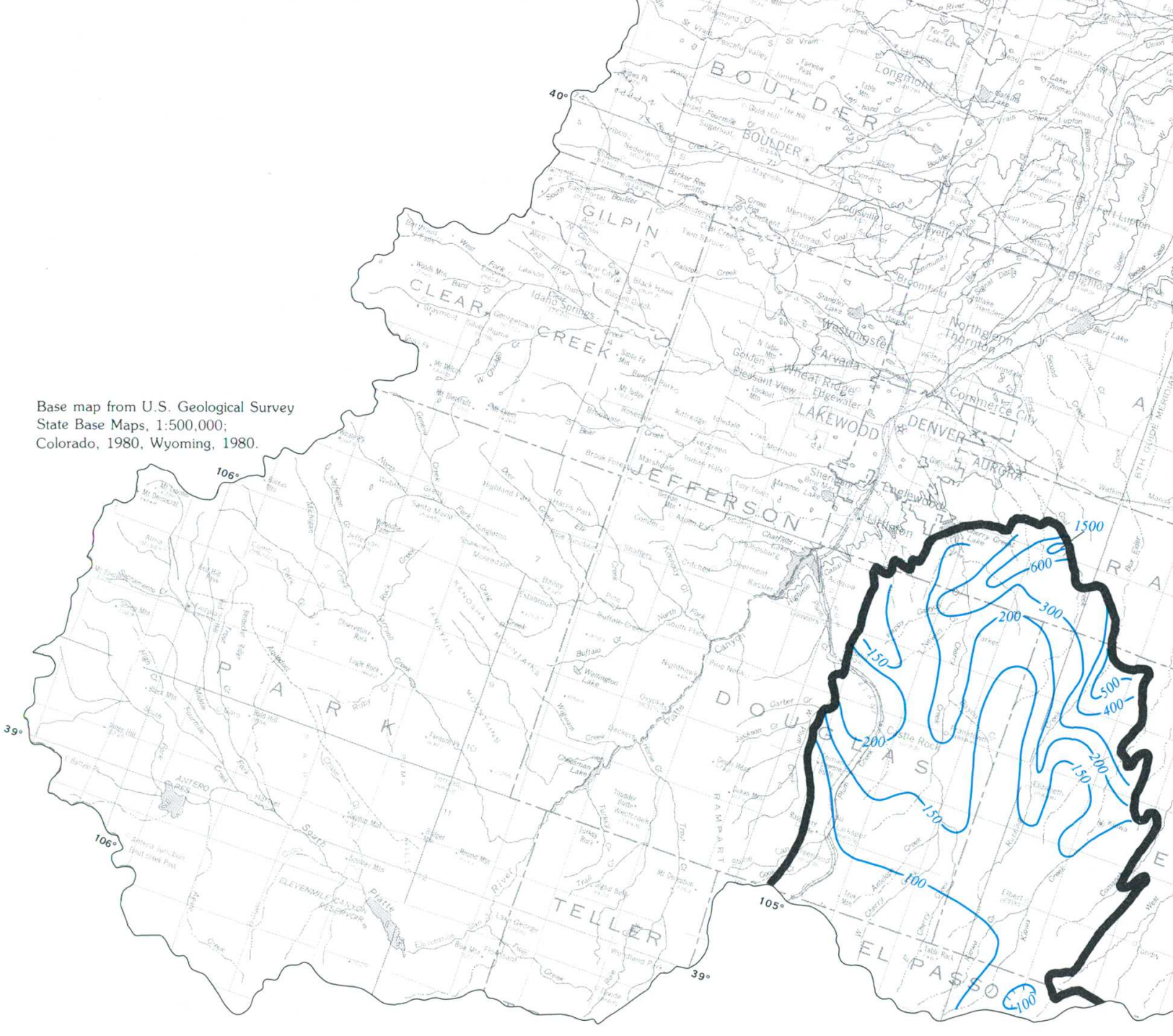

Figure 10.4-1 Dissolved-solids concentrations in the Dawson aquifer

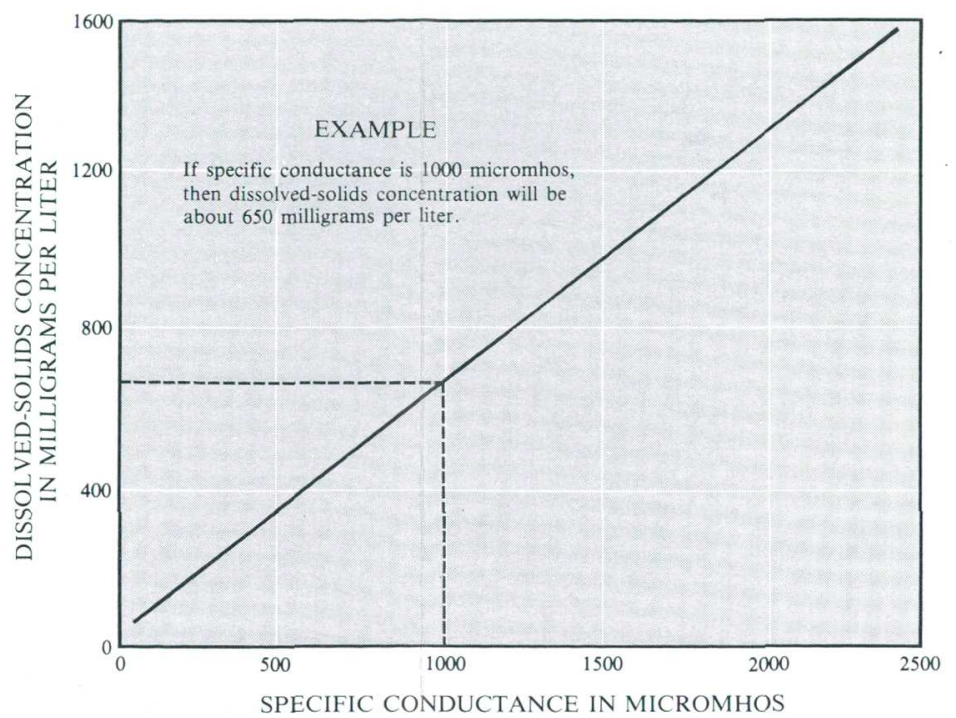

SPECIFIC CONDUCTANCE IN MICROMHOS
PER CENTIMETER AT $25^{\circ}$ CELSIUS

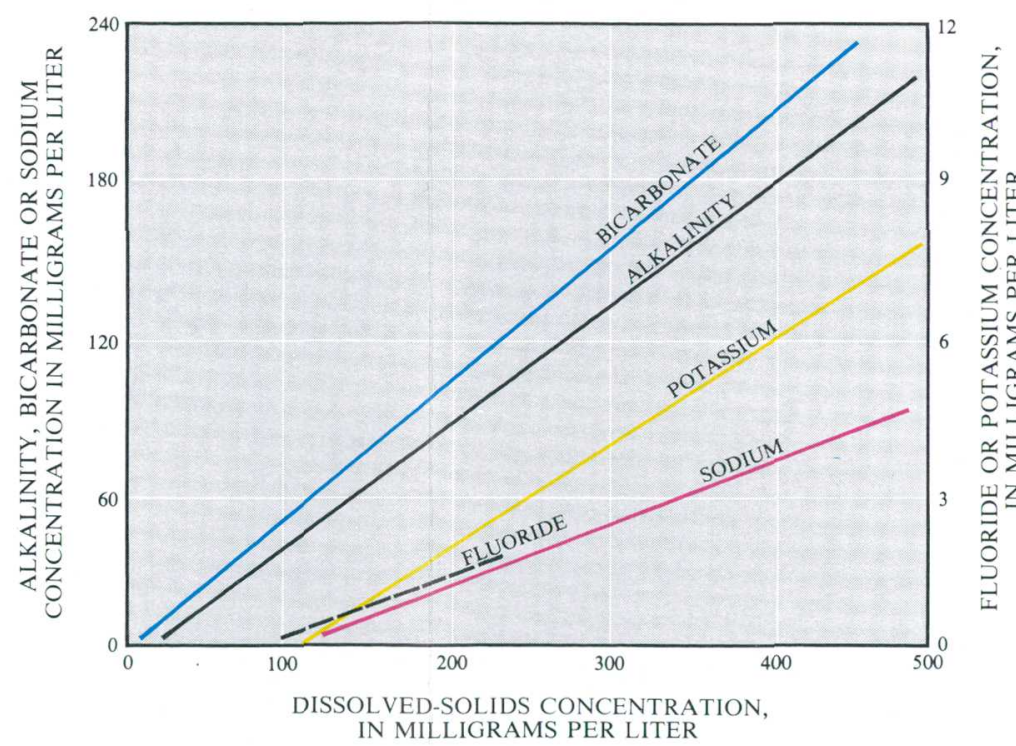

Figure 10.4-2 Water-quality relations in the Dawson aquifer 


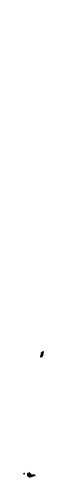




\title{
11.0 WATER-DATA SOURCES
}

11.1 Introduction

\section{NAWDEX, WATSOTRE, OWDC, and STORET Have Water-Data Information}

\author{
Water data are collected nationwide by many organizations \\ in response to a wide variety of needs.
}

Four activities, primarily within the U.S. Geological Survey, help to identify and improve access to the vast amount of existing water data:

(1) The National Water-Data Exchange (NAWDEX), which indexes the water data available from more than 400 organizations and serves as a central assistance center to help those needing water data to determine what information already is available.

(2) The National Water-Data Storage and Retrieval System (WATSTORE), which serves as the central repository of water data collected by the U.S. Geological Survey and which contains large amounts of data on the quantity and quality of both surface and ground waters.

(3) The Office of Water-Data Coordination (OWDC), which coordinates Federal water-data acquisition activities and maintains a "Catalog of Information on Water Data." To assist in identi- fying available water-data activities in coal provinces of the United States, special indexes to the Catalog are being printed and made available to the public.

(4) STORET, which catalogs data relating to the quality of the waterways within the contiguous United States, is maintained by the U.S. Environmental Protection Agency.

In addition to U.S. Geological Survey waterdata activities, the U.S. Environmental Protection Agency operates a data base called the Water-Quality Control Information System (STORET). This data base is used for the storage and retrieval of data relating to the quality of waterways within and contiguous to the United States.

More detailed explanation of these four activities is given in sections $11.2,11.3,11.4$, and 11.5. 


\title{
11.0 WATER-DATA SOURCES--Continued 11.2 NAWDEX
}

\section{National Water-Data Exchange Simplifies Access to Water Data}

\author{
The National Water-Data Exchange (NAWDEX) is a nationwide program, managed \\ by the U.S. Geological Survey to assist users of water data or water-related data \\ in identifying, locating, and acquiring needed data.
}

NAWDEX is a national confederation of wateroriented organizations working together to make their data more readily accessible and to facilitate a more efficient exchange of water data.

Services are available through a Program Office located at the U.S. Geological Survey's National Center in Reston, Virginia, and a nationwide network of Assistance Centers located in 45 States and Puerto Rico, which provide local and convenient access to NAWDEX facilities (see fig. 11.2-1). A directory is available on request that provides names of organizations and persons to contact, addresses, telephone numbers, and office hours for each of these locations [Directory of Assistance Centers of the National Water-Data Exchange (NAWDEX), U.S. Geological Survey Open-File Report 80-1193].

NAWDEX can assist any organization or individual in identifying and locating needed water data by providing the name of the organization that retains the data required. To accomplish this service, NAWDEX maintains a computerized Master Water-Data Index (fig. 11.2-2), which identifies sites for which water data are available, the type of data available for each site, and the organization retaining the data. A Water-Data Sources Directory (fig. 11.2-3) also is maintained that identifies organizations that are sources of water data and the locations of these organizations from which data may be obtained. In addition, NAWDEX has direct access to some large water-data bases of its members and has reciprocal agreements for the exchange of services with others.

Charges for NAWDEX services are assessed at the option of the organization providing the requested data or data service. Search assistance services are provided free by NAWDEX to the greatest extent possible. Charges are assessed, however, for those requests requiring computer cost, extensive personnel time, duplicating services, or other costs incurred by NAWDEX in the course of providing services. In all instances, charges assessed by NAWDEX Assistance Centers will not exceed the direct costs incurred in responding to the data request. Estimates of costs are provided by NAWDEX upon request and when costs are anticipated to be substantial.

For additional information concerning the NAWDEX program or its services contact:

Program Office
National Water-Data Exchange (NAWDEX)
U.S. Geological Survey
421 National Center
12201 Sunrise Valley Drive
Reston, Virginia 22092
Telephone: (703) $860-6031$
FTS 928-6031
Hours: 7:45 to 4:15 Eastern Standard Time
or
COLORADO
U.S. Geological Survey
Water Resources Division
BS 415 Dox 25046 Denver Federal Center
Denver, CO 80225

WYOMING

U.S. Geological Survey

Water Resources Division

P.O. Box 1125

Cheyenne, WY 82001 


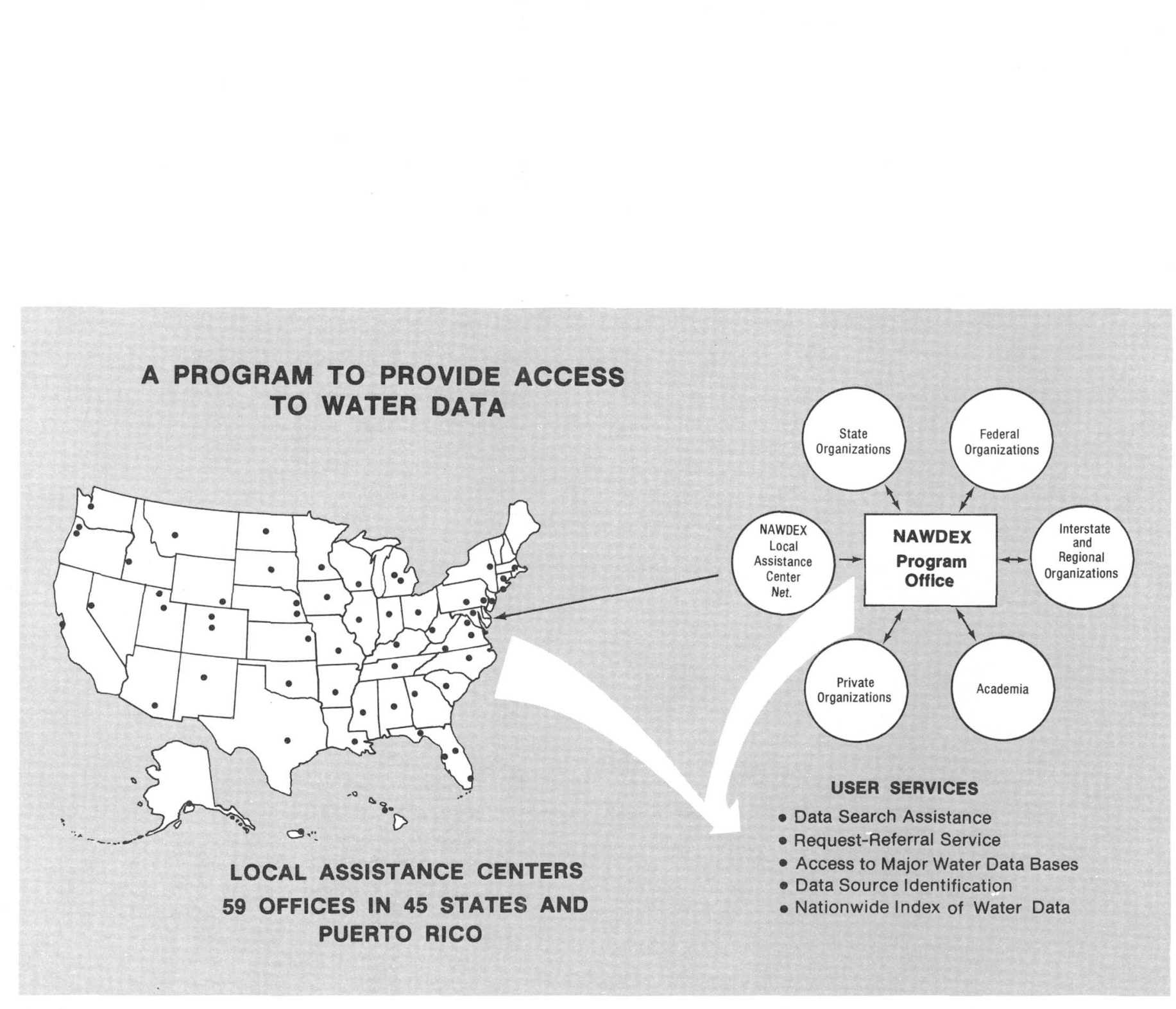

Figure 11.2-1 Access to water data.

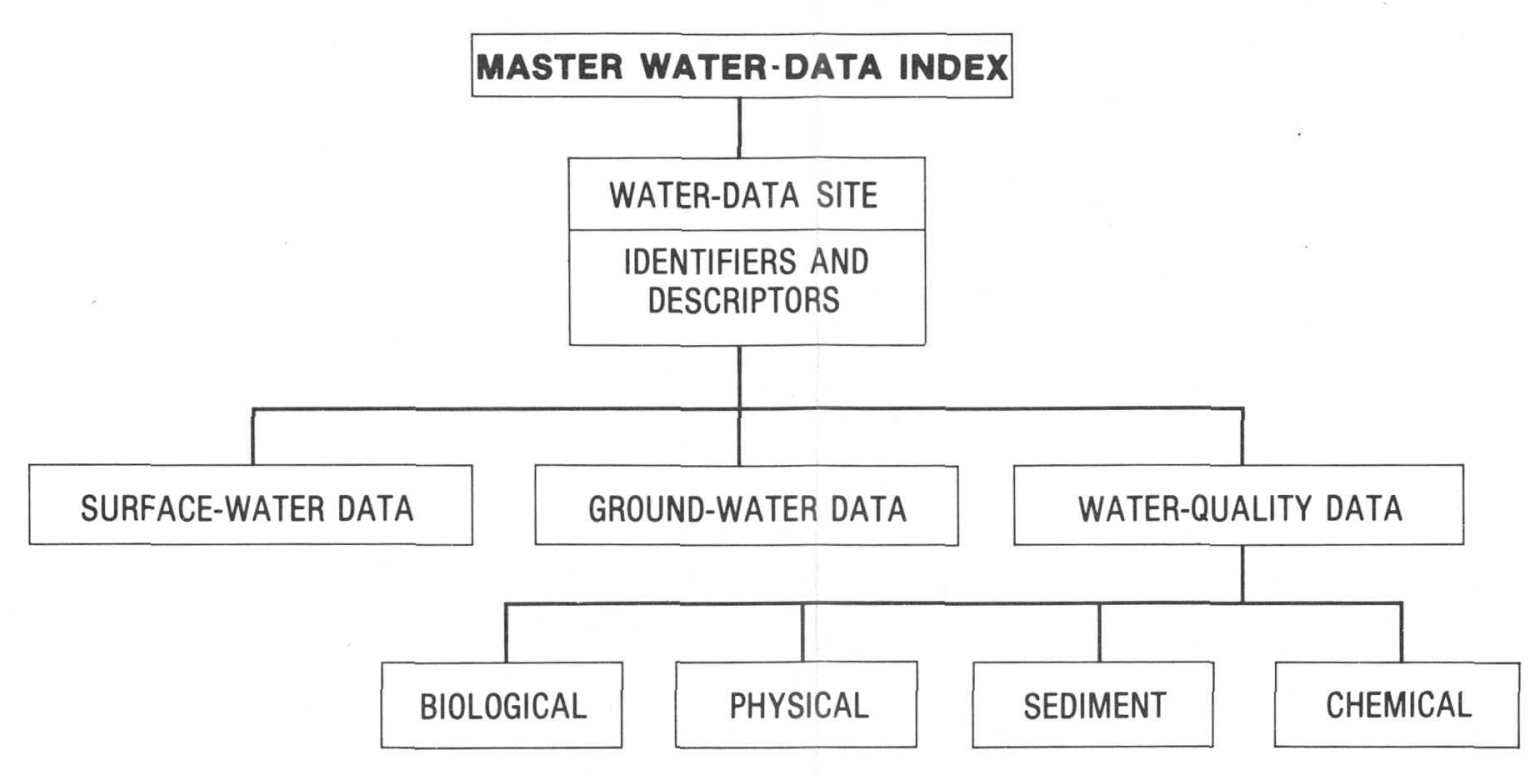

Figure 11.2-2 Master water-data index.

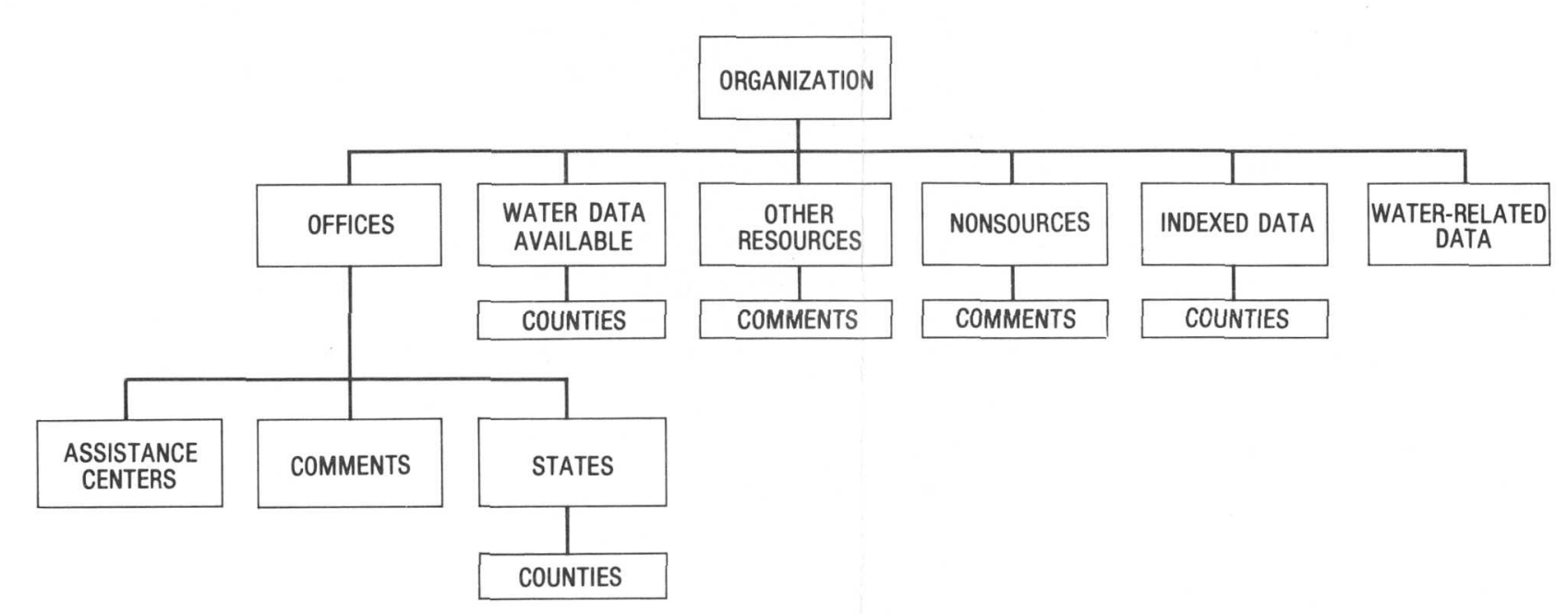

Figure 11.2-3 Water-data sources directory. 
11.0 WATER-DATA SOURCES--Continued

11.3 WATSTORE

\title{
WATSTORE Automated Data System
}

\author{
The National Water-Data Storage and Retrieval System (WATSTORE) of the \\ U.S. Geological Survey provides computerized procedures and techniques \\ for processing water data and provides effective and efficient \\ management of data-releasing activities.
}

The National Water-Data Storage and Retrieval System (WATSTORE) was established in November 1971 to computerize water information in the U.S. Geological Survey's files and to provide for more effective and efficient management of its data-releasing activities. The system is operated and maintained on the central computer facilities of the Survey at its National Center in Reston, Virginia. Data may be obtained from WATSTORE through the Water Resources Division's 46 district offices. General inquiries about WATSTORE may be directed to:

$$
\begin{gathered}
\text { Chief Hydrologist } \\
\text { U.S. Geological Survey } \\
437 \text { National Center } \\
\text { Reston, VA } 22092 \\
\text { or } \\
\text { District Chief } \\
\text { U.S. Geological Survey } \\
\text { Water Resources Division } \\
\text { MS 415 } \\
\text { Box 25046 Denver Federal System } \\
\text { Denver, CO 80225 } \\
\text { or } \\
\text { District Chief } \\
\text { U.S Geological Survey } \\
\text { Water Resources Division } \\
\text { P.O. Box 1225 } \\
\text { Cheyenne, WY } 82001
\end{gathered}
$$

The Geological Survey currently (1982) collects data at approximately 16,000 streamflow-gaging stations, 1,000 lakes and reservoirs, 5,200 surface-water-quality stations, 1,020 sediment stations, 30,000 water-level observation wells, and 12,500 ground-water-quality wells. Each year many water-data collection sites are added and others are discontinued; thus, large amounts of diversified data, both current and historical, are amassed by the Survey's data-collection activites.
The WATSTORE system consists of several files in which data are grouped and stored by common characteristics and data-collection frequencies. The system also is designed to allow for the inclusion of additional data files as needed. Currently, files are maintained for the storage of: (1) Surface-water, water-quality, and ground-water data measured daily or continuously; (2) annual peak values for streamflow stations: (3) chemical analyses for surface- and ground-water stations; (4) water parameters measured more frequently than daily; and (5) geologic and inventory data for groundwater stations. In addition, an index file for stations for which data are stored in the system is also maintained (fig. 11.3-1). A brief description of each file is as follows.

Station-Header File: All sites for which data are stored in the Daily Values, Peak Flow, Water-Quality, and Unit Values files of WATSTORE are indexed in this file. It contains information pertinent to the identification, location, and physical description of nearly 220,000 sites.

Daily-Values File: All water-data parameters measured or observed either on a daily or on a continuous basis and numerically reduced to daily values are stored in this file. Instantaneous measurements at fixed time intervals, daily mean values, and statistics such as daily maximum and minimum values also may be stored. This file currently contains more than 200 million daily values including data on streamflow, river stages, reservoir contents, water temperatures, specific conductance, sediment concentrations, sediment discharges, and ground-water levels.

Peak-Flow File: Annual maximum (peak) streamflow (discharge) and gage height (stage) values at surfacewater sites comprise this file, which currently contains more than 400,000 peak observations.

Water-Quality File: Results of more than 1.4 million analyses of water samples that describe the chemical, physical, biological, and radiochemical characteristics of both surface and ground waters are contained in this 
file. These analyses contain data for 185 different
constituents.

Unit-Values File: Water parameters measured on a schedule more frequent than daily are stored in this file. Rainfall, stream discharge, and water temperature are File.

Ground-Water Site-Inventory File: This file discussed above, but it is cross-referenced to the Water-Quality File and the Daily-Values File. It contains inventory data for wells, springs, and other sources of ground water. The
data included are site location and identification, geohydrologic characteristics, well-construction history, and one-time field measurements such as wate

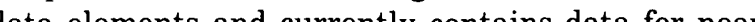
70,000 sites.

All data files of the WATSTORE system are maintained and managed on the central computer facilities of the Geological Survey at its National Center. However, data may be entered into and retrieved from nationwide telecommunication network.

Remote Job-Entry Sites: Almost all Water Resource Division district offices are equipped with high-speed computer terminals for remote access to the WATSTORE system. These terminals allow each site to enter data into or retrieve data from the system within an interval priority placed on the request. The number of remote job entry sites is increased as the need arises.

Digital-Transmission Sites: Digital recorders are used at many field locations to record values for parameters such as river stage, conductivity, water centration. Data are recorded on 16 chand the tape is removed periodically from the recorder, and the data are transmitted over telephone lines to the receiver at Reston, Virginia. The data are re-recorded on magnetic tape for use on the central computer. Exdicates their fessibility for transmitting rous indicates their feasibility for transmitting real-time transmitters are used as the communication link to the satellite. About 200 data-relay stations are being operated currently (1980).

Central-Laboratory System: The Water Resources Division's water-quality laboratory, Water in Denver,
Colorado, analyzes more than 150,000 water samples per year. This laboratory is equipped to automatically persimple inorganic substances, such as chlorides, to com. plex organic compounds, such as pesticides. As each analysis is completed, the results are verified by laboratory personnel and transmitted via a computer terminal to the central computer facilities to be stored in Water-Quality File of WATSTORE

Water data are used in many ways by decision. makers for the management, development, and monitoring of our water resources. In addition to its data processing, storage, and retrieval capabilities, WATSTORE can provide a variety of useful products ranging from simple tables of data to complex statistical analy fos. A minimal fee, plus the actual computer cost incurred in

Computer-Printed Tables: Users most often request data from WATSTORE in the form of tables printed by the computer. These tables may contain lists of actual data or condensed indexes that indicate the availability to display the the files. Many formats are available

Computer-Printed Graphs: Computer-printed graphs for the rapid analysis or display of data are another frophs, frequency-distribution curves, X-Y point plots, site作, printers.

Statistical Analyses: WATSTORE interfaces with a proprietary statistical package (SAS) to provide extensive analyses of data such as regression analyses,

Digital Plotting: WATSTORE alo makes us of ware systems that prepare data for digital plotting on
peripheral offline plotters available at the central computer site. Plots that can be obtained include hydrographs, frequency-distribution curves, X.Y point plots, contour plots, and three-dimensional plots.

Data in Machine-Readable Form: Data stored in WATSTORE can be obtained in machine-readable form written computer programs. These data are available in the standard format of the WATSTORE system or in the form of punched cards or card images on magnetic tape.

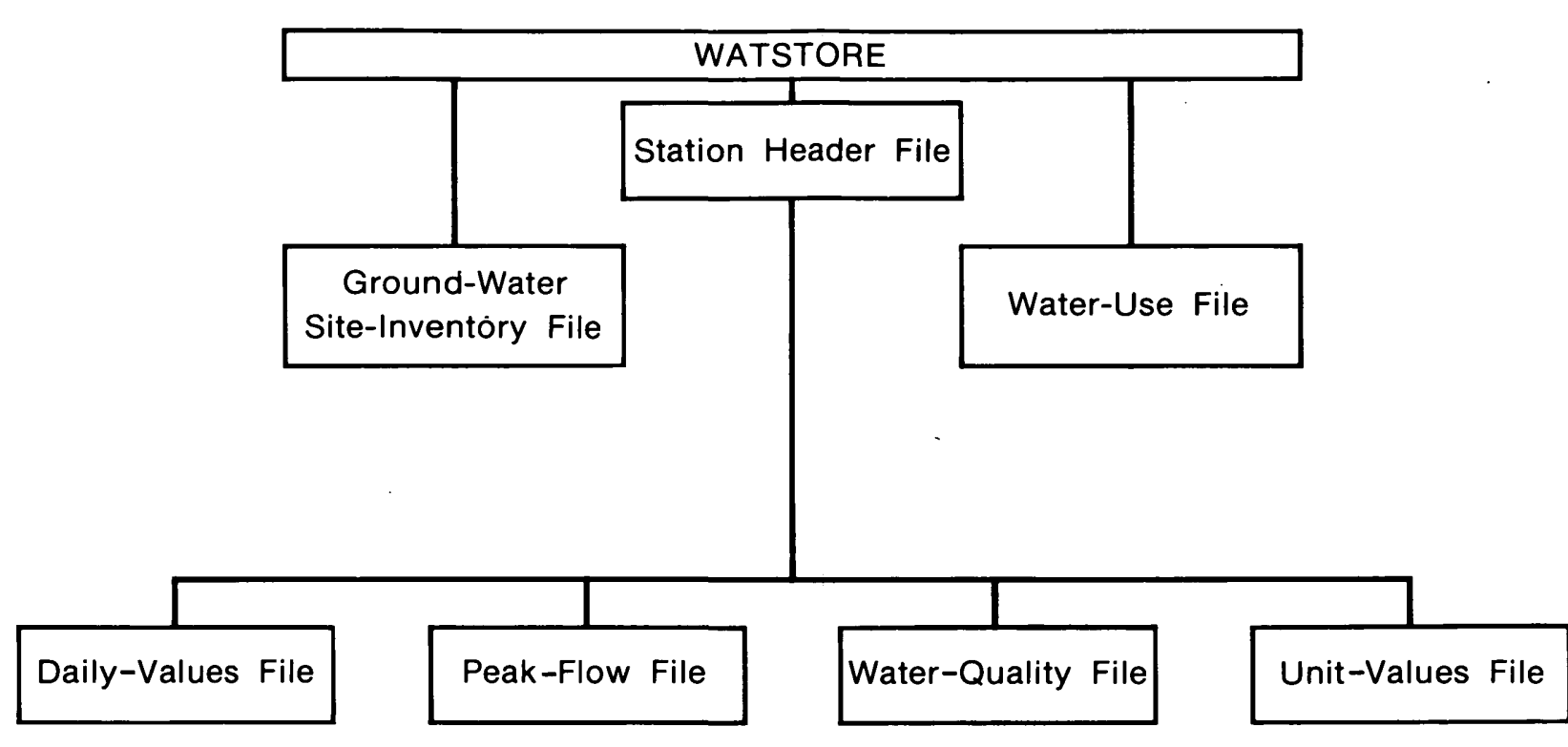

Figure 11.3-1 Index to file-stored data. 


\title{
11.0 WATER-DATA SOURCES--Continued 11.4 OWDC
}

\section{Water Data Indexed for Coal Provinces}

\author{
A special index, "Index to Water-Data Activities in Coal Provinces of the \\ United States," has been published by the U.S. Geological Survey's \\ Office of Water-Data Coordination (OWDC).
}

The "Index to Water-Data Activities in Coal Provinces of the United States" was prepared to assist those involved in developing, managing, and regulating the Nation's coal resources by providing information about the availability of water-resources data in the major coal provinces of the United States. It is derived from the "Catalog of Information on Water Data," which is a computerized information file of water-data acquisition activities in the United States, and its territories and possessions, with some international activities included.

This special index consists of five volumes (fig. 11.4-1). Volume I, Eastern Coal Province; Volume II, Interior Coal Province; Volume III, Northern Great Plains and Rocky Mountain Coal Provinces; Volume IV, Gulf Coast Coal Province; and Volume V, Pacific Coast and Alaska Coal Provinces. The information presented will aid the user in obtaining data for evaluating the effects of coal mining on water resources and in developing plans for meeting additional water-data needs. The report does not contain the actual data; rather, it provides information that will enable the user to determine if needed data are available.

Each volume of this special index consists of four parts: Part A, Streamflow and Stage Stations; Part B, Quality of Surface-Water Stations; Part C, Quality of Ground-Water Stations; and Part D, Areal Investigations and Miscellaneous Activities. Information given for each activity in Parts A-C includes: (1) The identification and location of the station, (2) the major types of data collected, (3) the frequency of data collection, (4) the form in which the data are stored, and (5) the agency or organization reporting the activity. Part D summarizes areal hydrologic investigations and water-data activities not included in the other parts of the index. The agencies that submitted the information, the agency codes, and the number of activities reported by type are are included.

Those who need additional information from the Catalog file or who need assistance in obtaining water data should contact the National Water-Data Exchange (NAWDEX) (see section 11.2).

Further information on the index volumes and their availability may be obtained from:

District Chief
U.S. Geological Survey
Water Resources Division
MS415 Box 25046 Denver Federal
Denver, CO 80225
or
District Chief
U:S. Geological Survey
Water Resources Division
P.O. Box 1225
Cheyenne, WY 82001

District Chief

U.S. Geological Survey

25046 Denver Federal System

Denver, CO 80225 


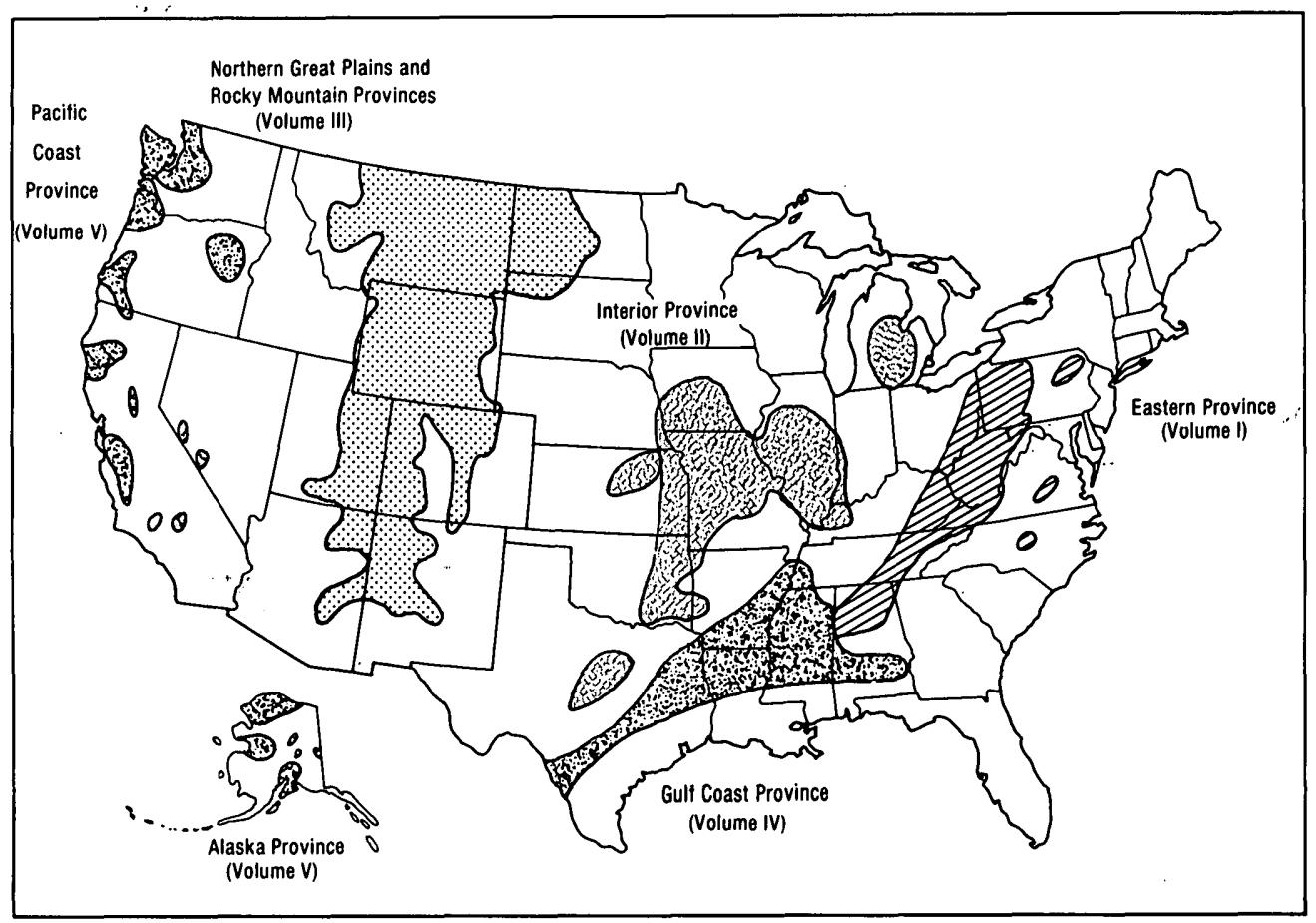

Figure 11.4-1 Index volumes and related provinces. 


\title{
11.0 WATER-DATA SOURCES--Continued \\ 11.5 STORET
}

\section{STORET is U.S. Environmental Protection Agency's Computerized Data-Base System}

\author{
STORET is the computerized water-quality data-base system \\ maintained by the U.S. Environmental Protection Agency
}

STORET is a computerized data base system maintained by the U.S. Environmental Protection Agency (1979) for the storage and retrieval of data relating to the quality of the waterways within and contiguous to United States. The system is used to store data on water quality, water-quality standards, point sources of pollution, pollution-caused fishkills, waste-abatement needs, implementation schedules, and other water-qualityrelated information. The Water-Quality File (WQF) is the most widely used STORET file.

The data in the WQF are collected through cooperative programs involving the EPA, State water pollution control authorities, and other governmental agencies. The U.S. Geological Survey, the U.S. Forest Service, the U.S. Army Corps of Engineers, the U.S. Bureau of Reclamation, and the Tennessee Valley Authority all use STORET's WQF to store and retrieve data collected through their water-quality monitoring programs.

There are 1,800 water-quality parameters are stored in STORET's WQF. In 1976 the data in the system represented more than 200,000 unique collection points in the system. Figure 11.5-1 illustrates the group of parameters and number of observations that are in the WQF.

State, Federal, interstate, and local government agencies can become STORET users. Information on becoming a user of the system can be obtained by contacting the Environmental Protection Agency. The point of contact for the Region $\mathrm{V}$ is:

$$
\begin{gathered}
\text { Director } \\
\text { Surveillance and Analysis Division } \\
\text { Environmental Protection Agency } \\
1660 \text { Lincoln Street Suite } 103 \\
\text { Denver, CO 80295 } \\
\text { Telephone: (303) 844-2226 }
\end{gathered}
$$

Source: Handbook Water-Quality Control Information System (STORET), U.S. Environmental Protection Agency, Office of Water and Hazardous Materials, Washington, D.C. 20460 


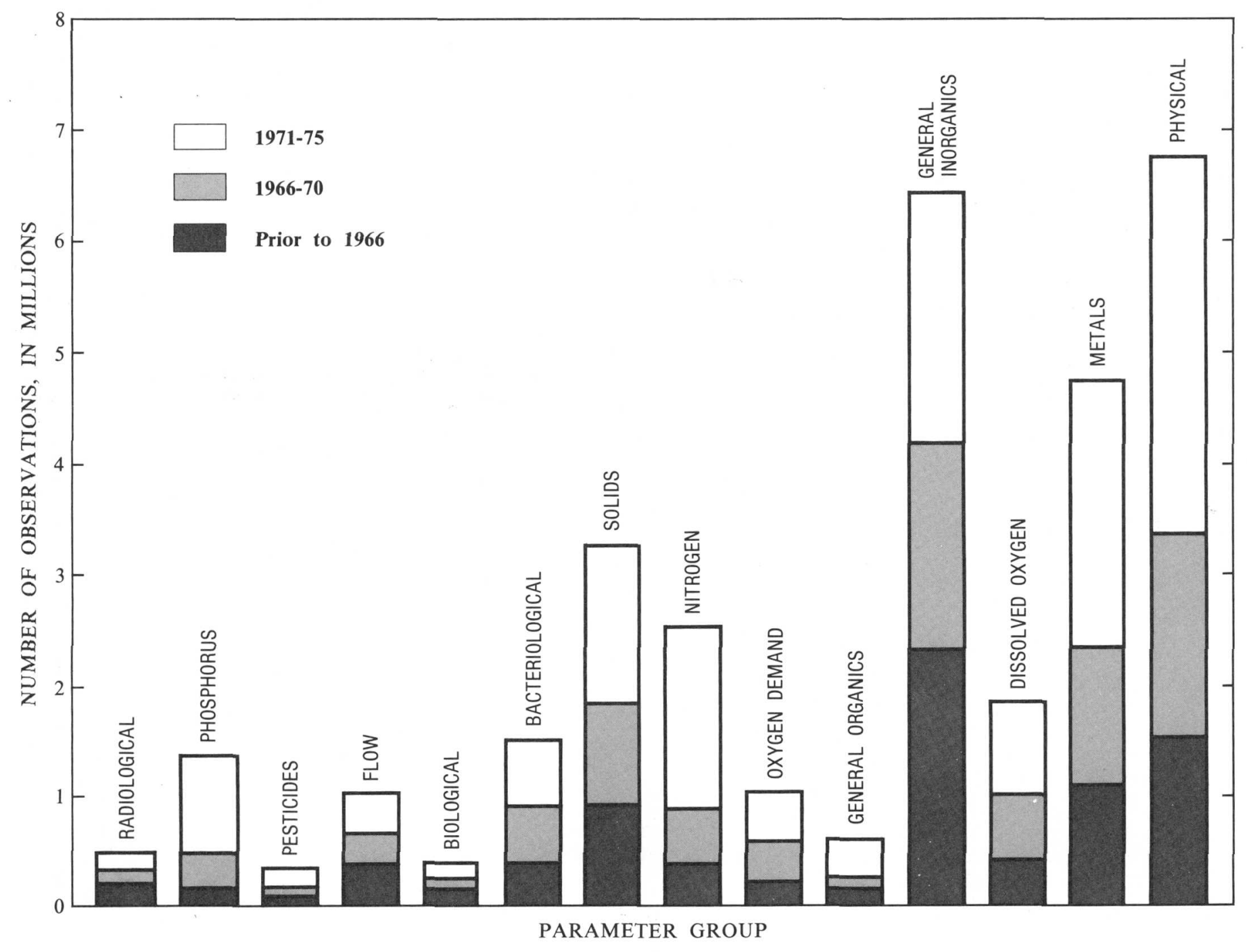

Figure 11.5-1 Parameter groups and numbers of observations in the Water Quality File. 


\subsection{SUPPLEMENTAL INFORMATION}

\subsection{Surface-Water Station index}

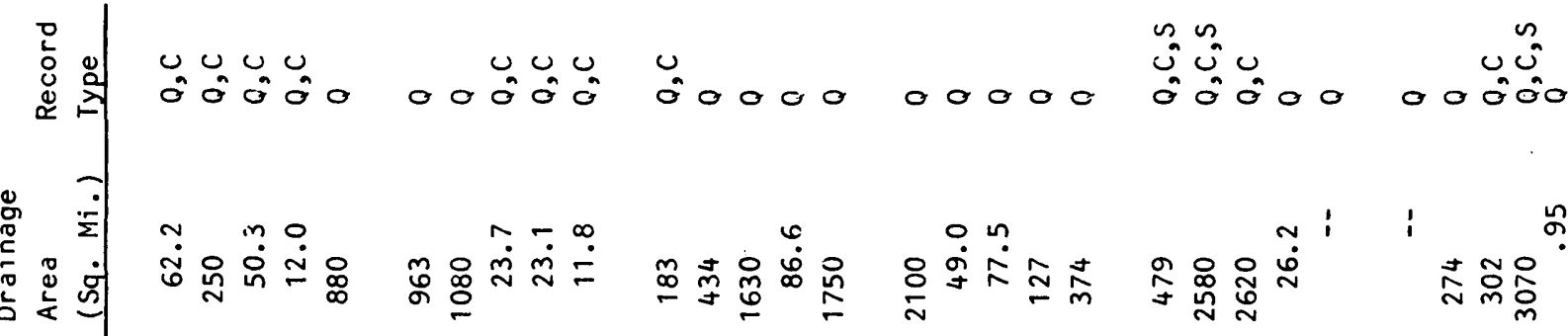

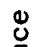

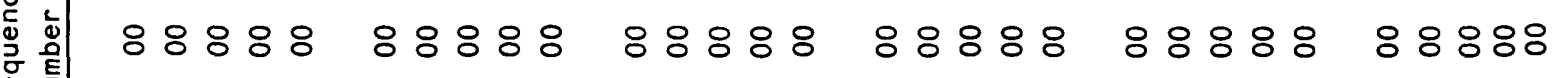
œ 2

\section{$\stackrel{0}{3}$}

ชิ

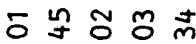

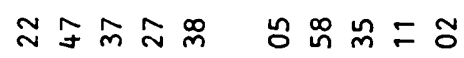

$\pm g=a$ in

- 음

$\approx$ กீกิ์̊

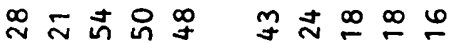

으 있 용 용요

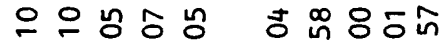

ஜํㅇ융

능ํㅇ능느응

ํํㄴ 능ํㅡ응 ํㅡ

ํํㄴ 농ํํㅇํํ은

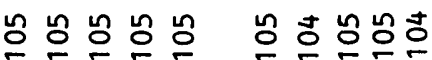

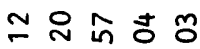

$\underline{I}=N \tilde{m}$

I

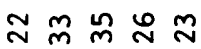

జิ $m$

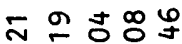

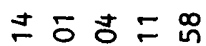

แี่

$\simeq$ ニ $8 \simeq \simeq$

ฝลลล

స స 요

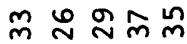

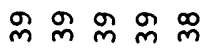

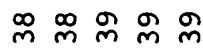

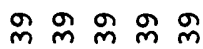

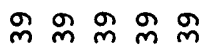

बे 요 क्

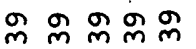

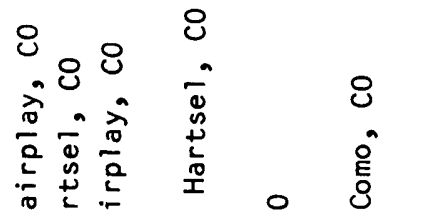

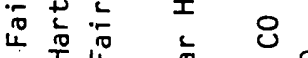

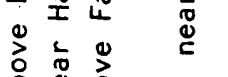

ن.

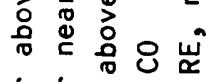

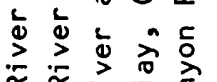

\&

व व व

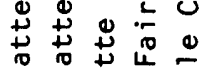

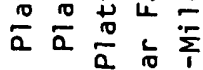

돈

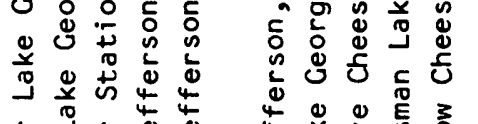

万ั

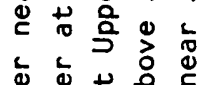

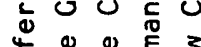

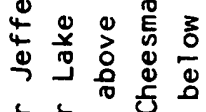

告

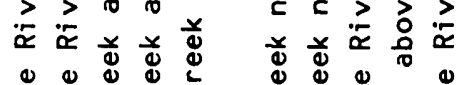

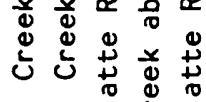

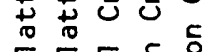

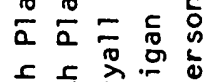

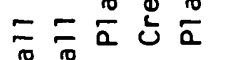

8 8

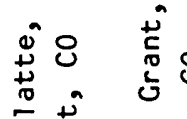

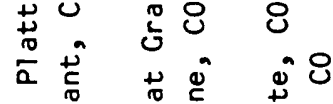

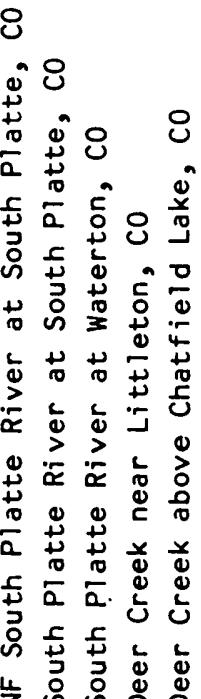

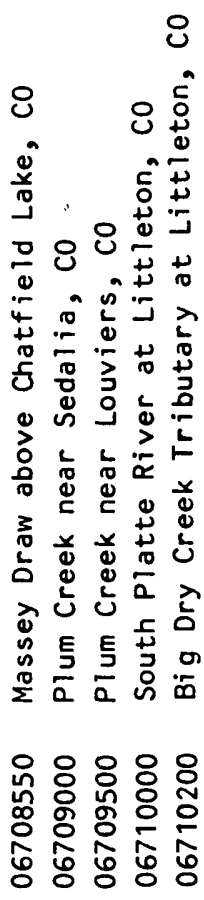

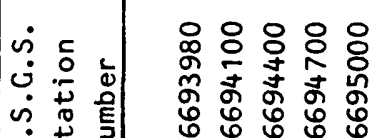

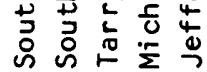

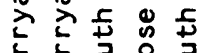

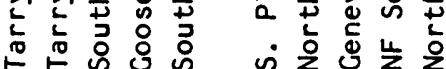

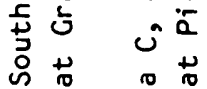

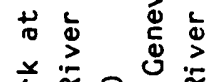

ᄂ

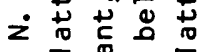

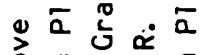

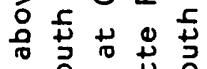

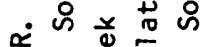

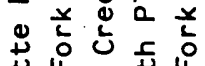

苗

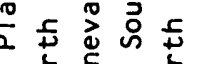

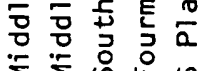

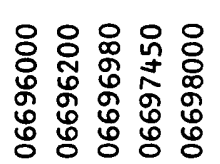

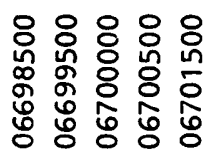

웅융ㅇㅇㅇํํ

융유윳ำ

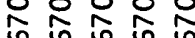

융융유

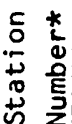

$-n m \pm n$

- $N$ a

$\Xi \approx m \pm \cong$

노용요

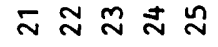

$\stackrel{\sim}{\sim} \stackrel{\infty}{\sim}$ 옹 


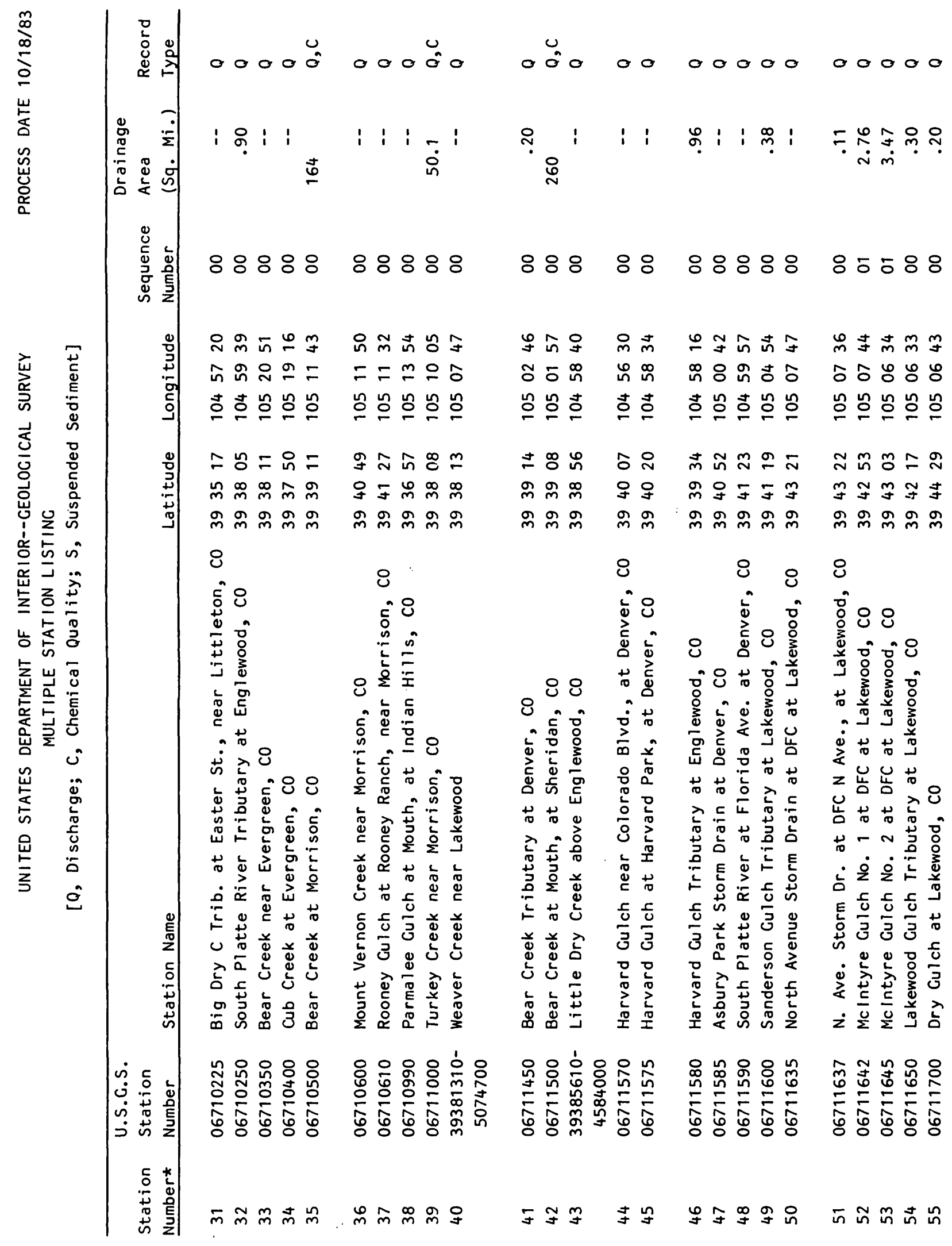




\subsection{SUPPLEMENTAL INFORMATION--Continued}

\subsection{Surface-Water Station index}

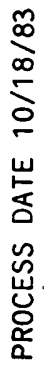

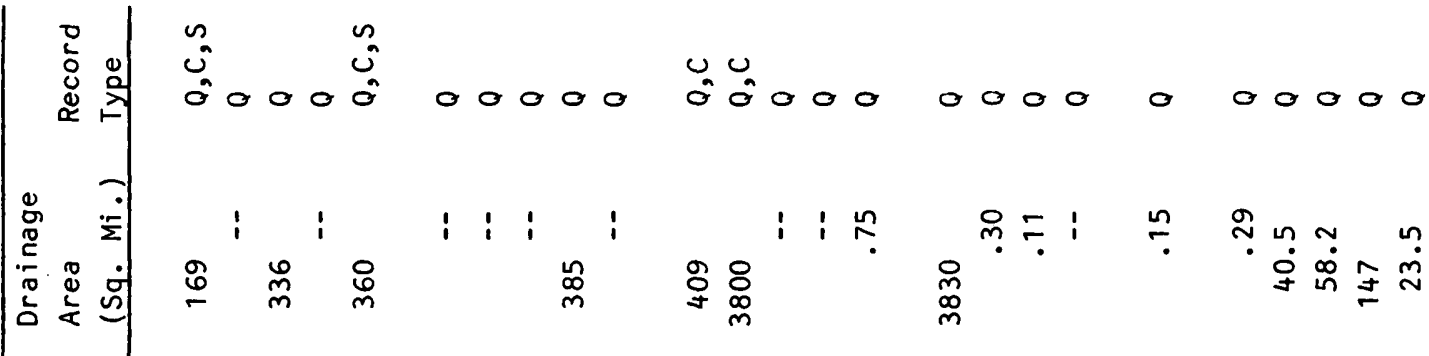

幽 œ 2

요용

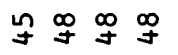

이뉴ำษ

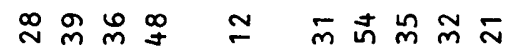

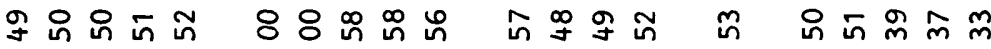

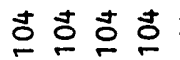

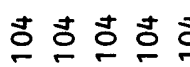

농응능흐문

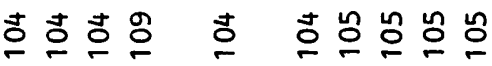

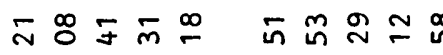

i̊n

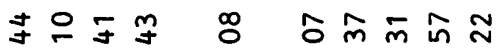

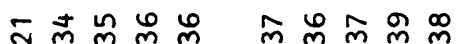

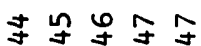

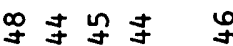

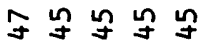

के

요 \%

के

or 90

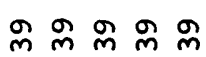

8

ㄴㅇㅇ

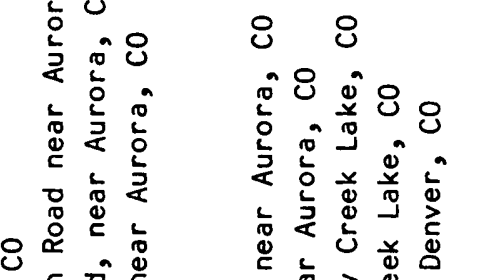

1888

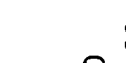

ن

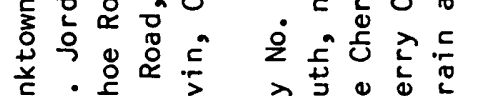

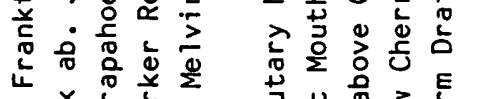

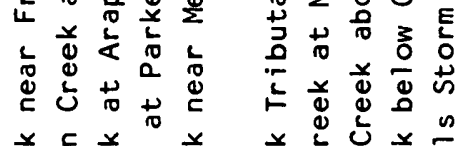

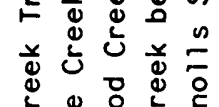

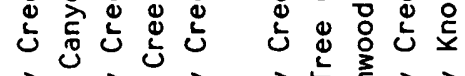

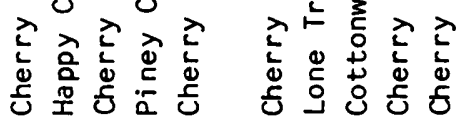

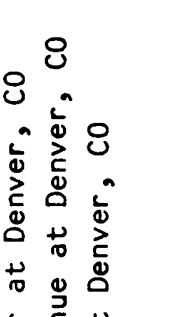

88

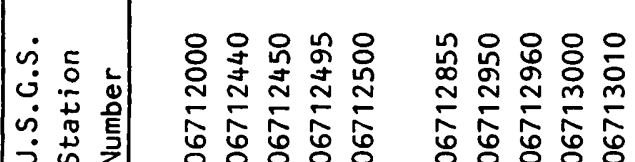

讨勇崩

○㐫心

O

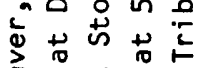

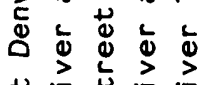

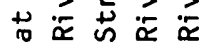

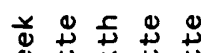

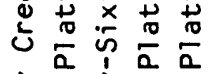

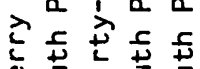

交

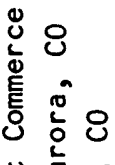

范艾

닌

मे

吉苔范范

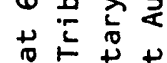

व

这上范

苟它

焉造离

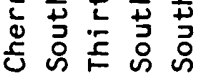

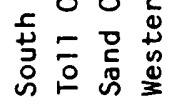

융ㅇㅇㅇ은 은

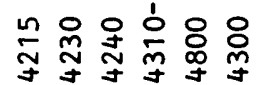

$\overline{1} \overline{1} \frac{1}{1}$

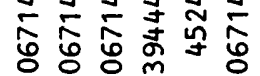

88

ช : ฆ

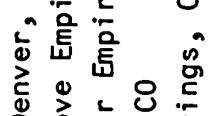

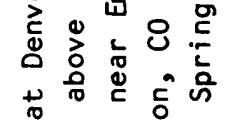

>

苟㐫充过

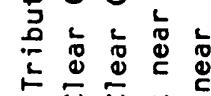

$上 \frac{0}{U} \div$

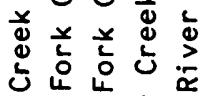

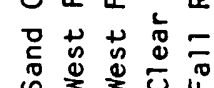

응 용용

는응

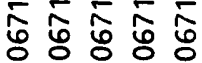




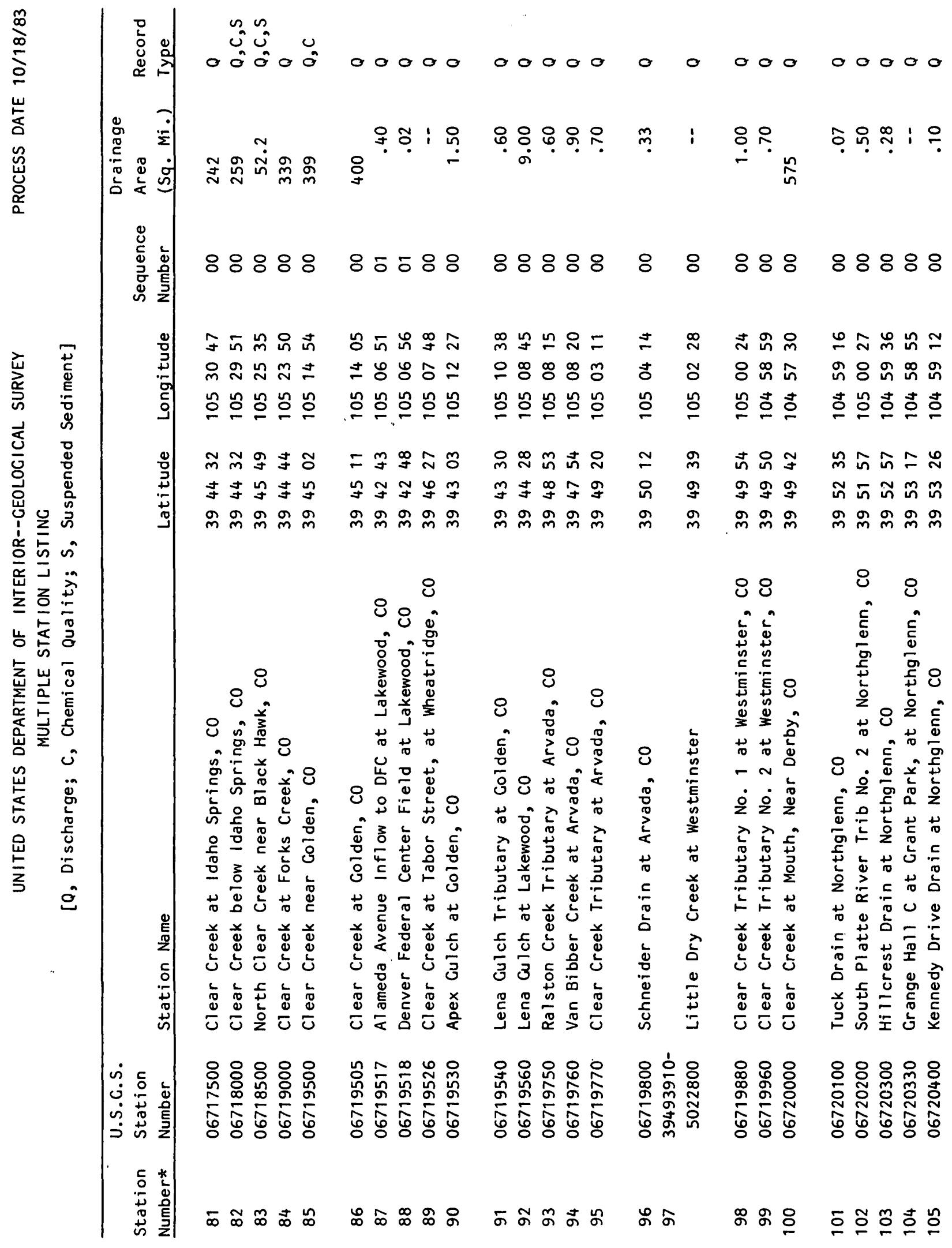




\subsection{SUPPLEMENTAL INFORMATION--Continued}

12.1 Surface-Water Station index

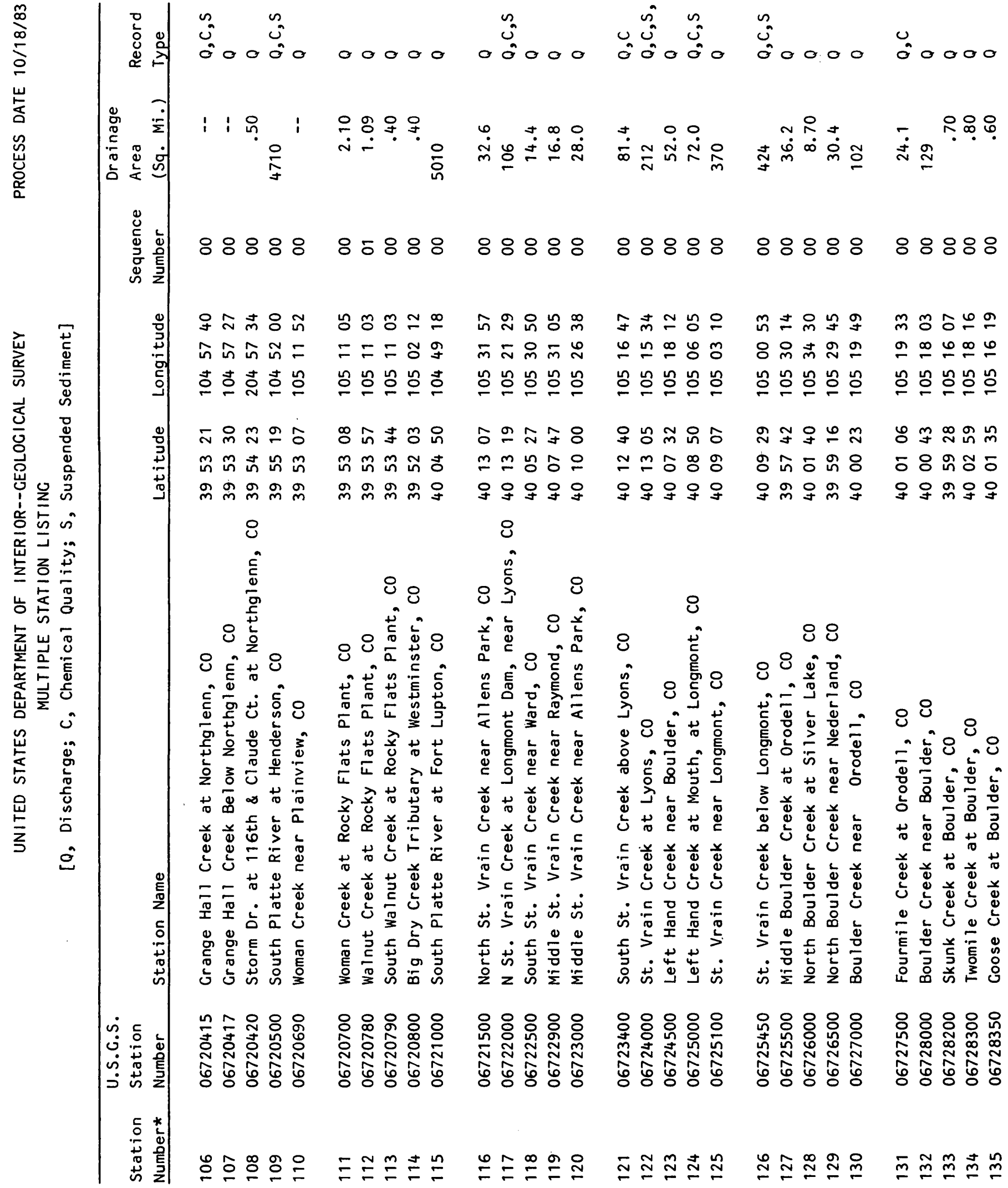




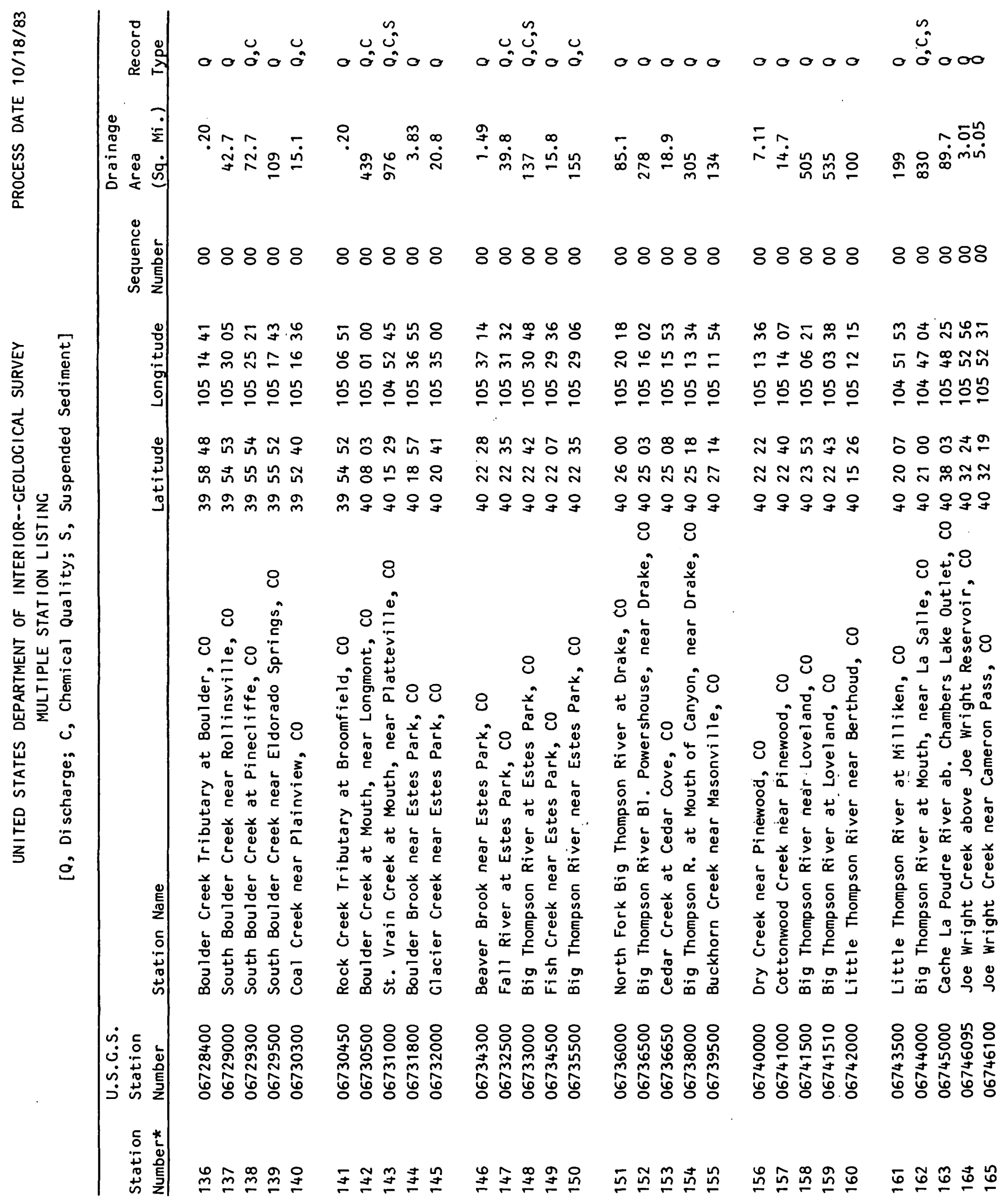

\subsection{SUPPLEMENTAL INFORMATION--Continued 12.1 Surface-Water Station index}




\subsection{SUPPLEMENTAL INFORMATION--Continued}

12.1 Surface-Water Station index

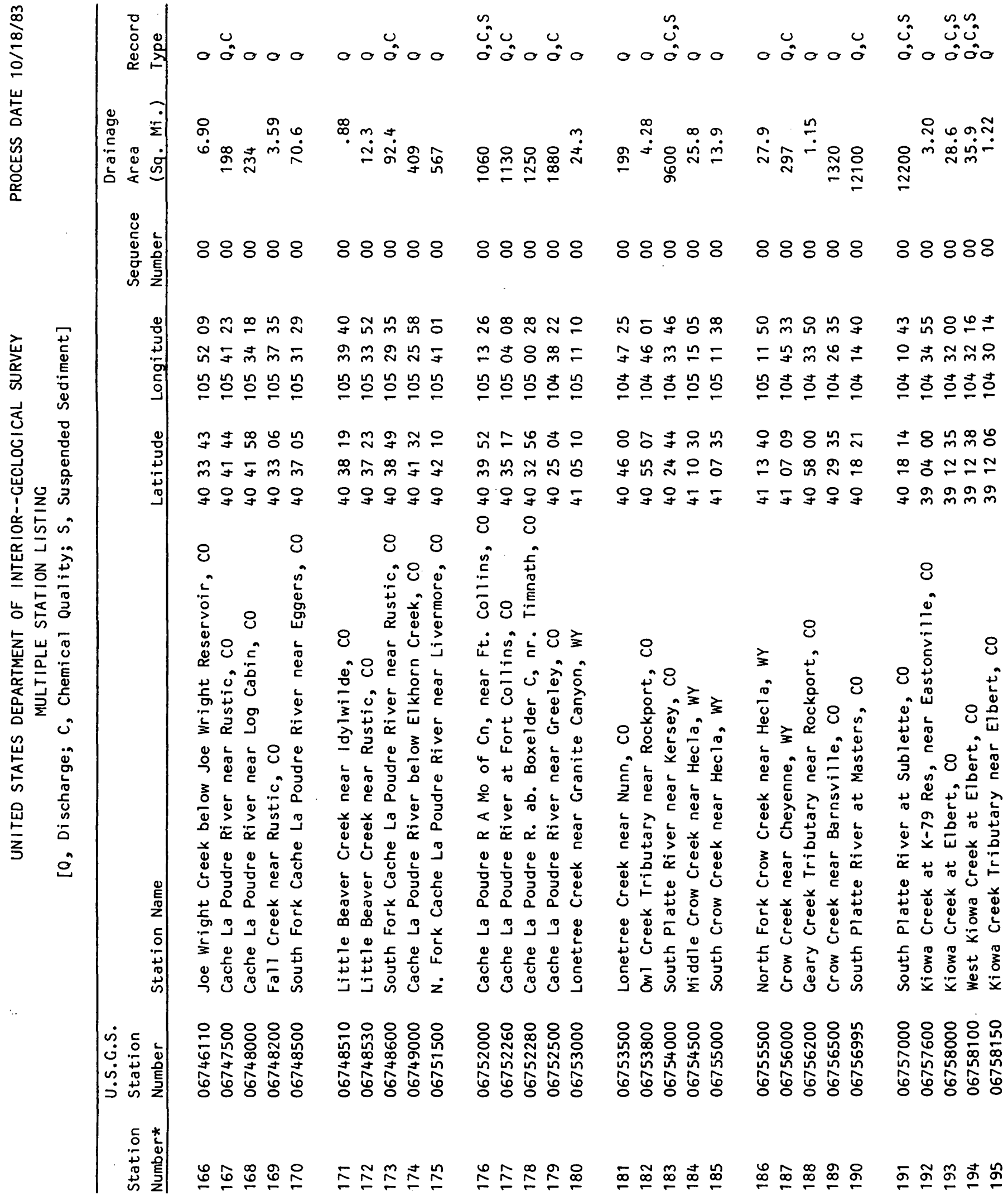




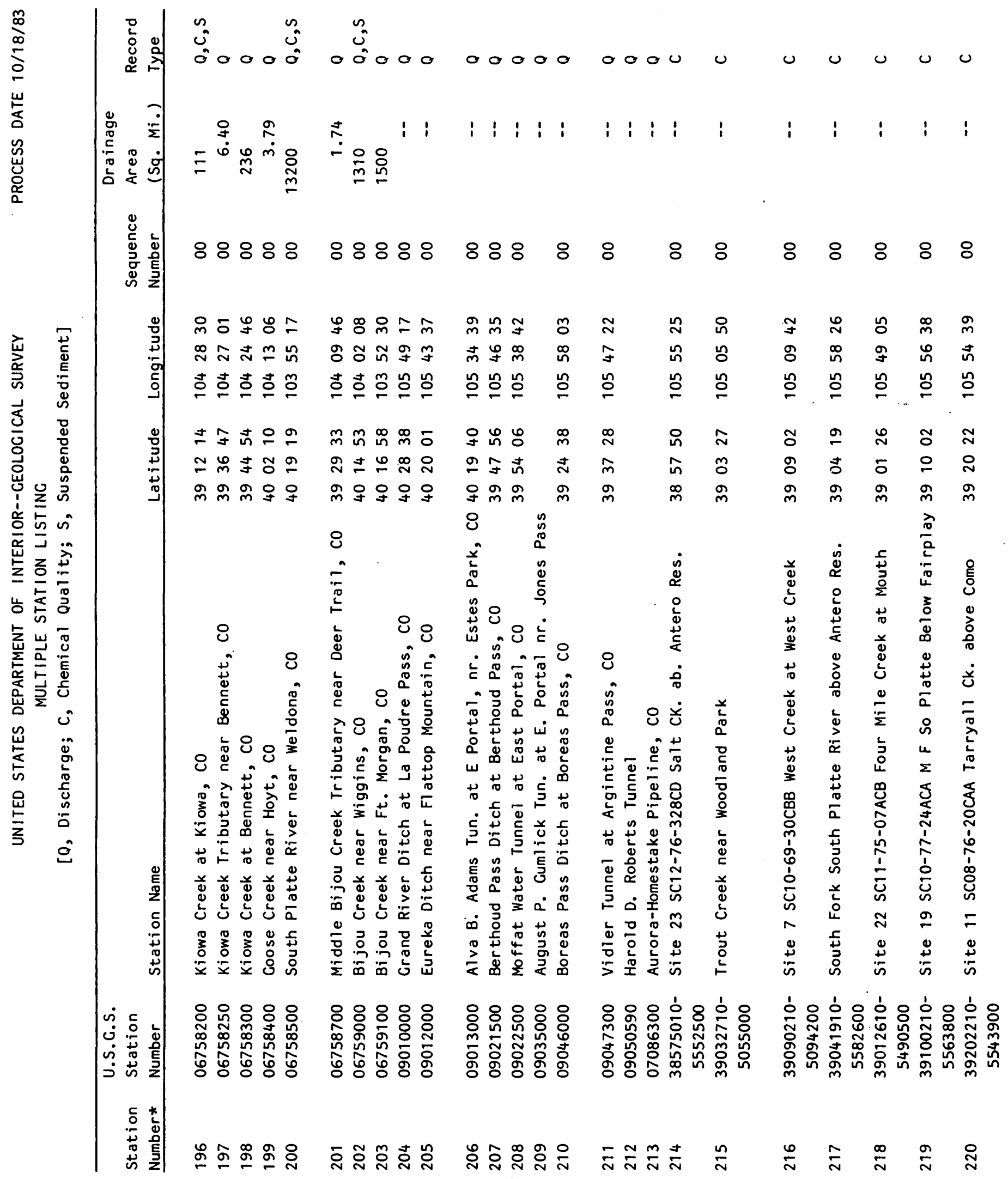




\subsection{SUPPLEMENTAL INFORMATION--Continued}

12.1 Surface-Water Station-index

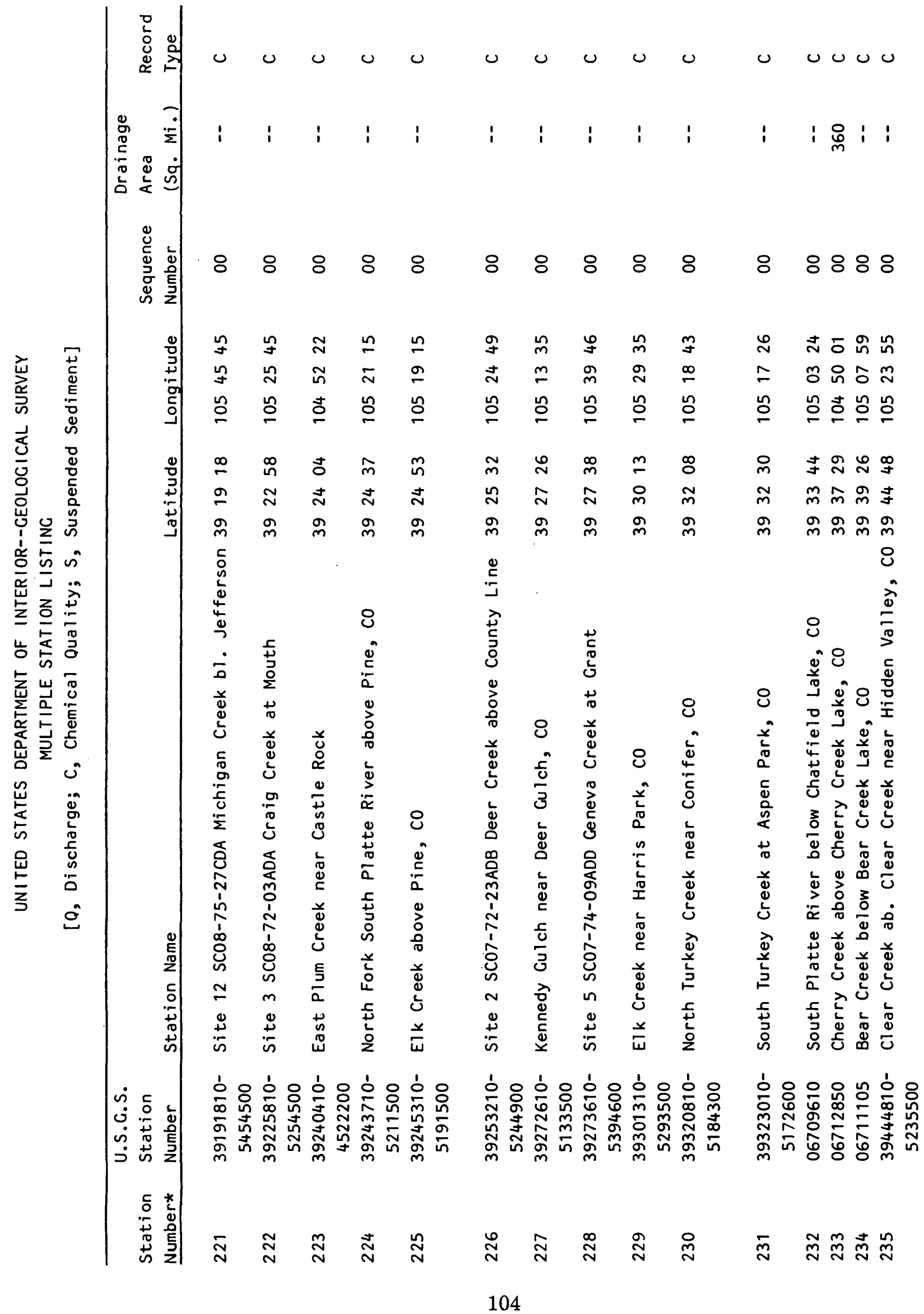




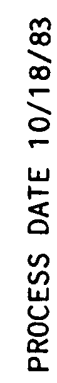

88888 8 8888 ㅇ 8888

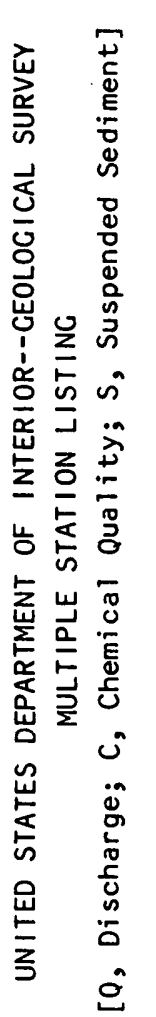

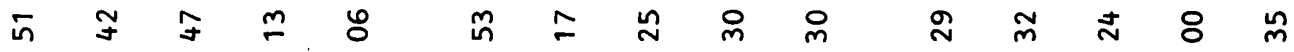

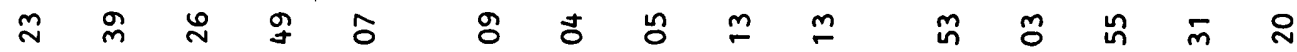

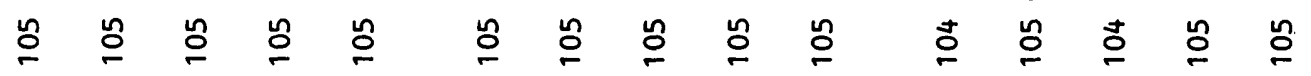

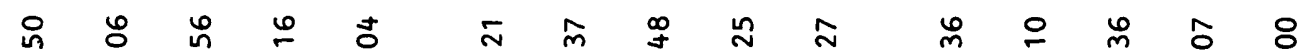

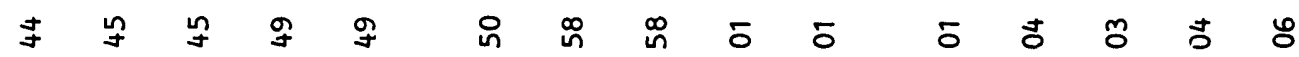

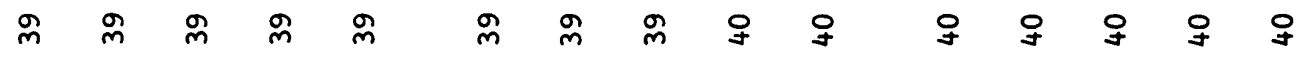
8 \& 8 \& $\quad \underset{0}{0}$

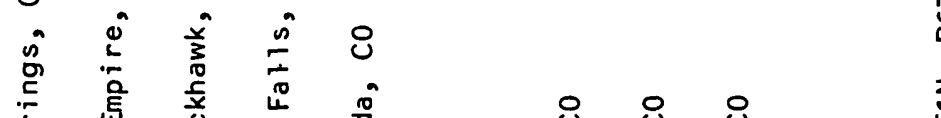

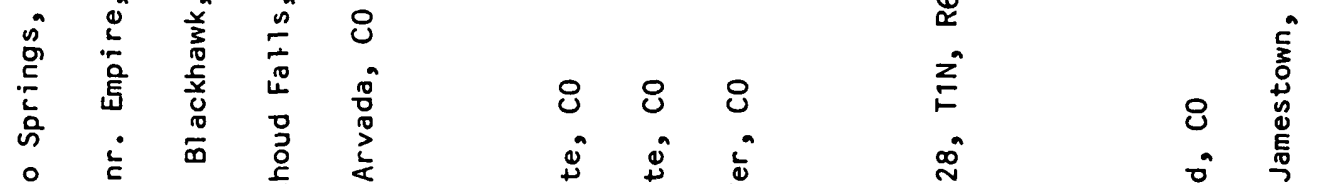

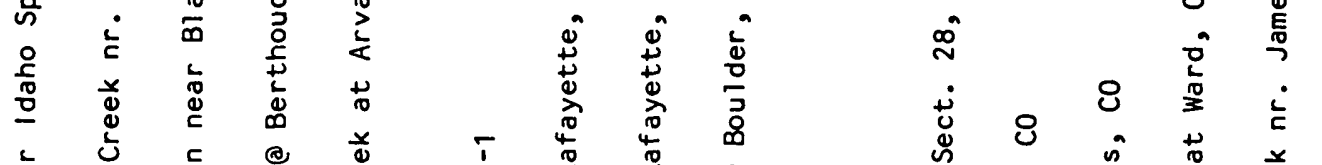

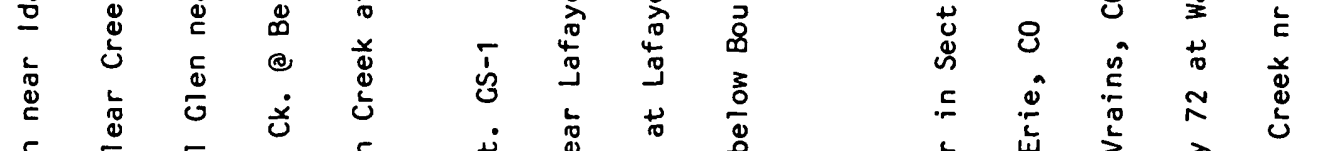

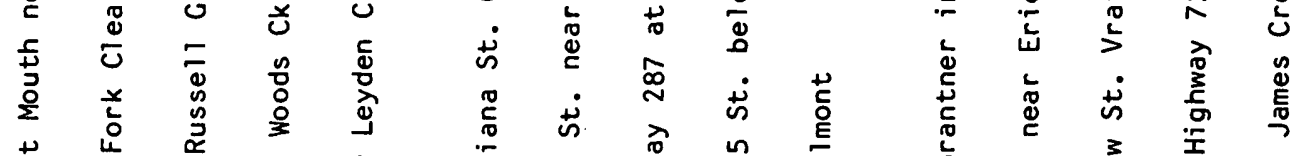
范

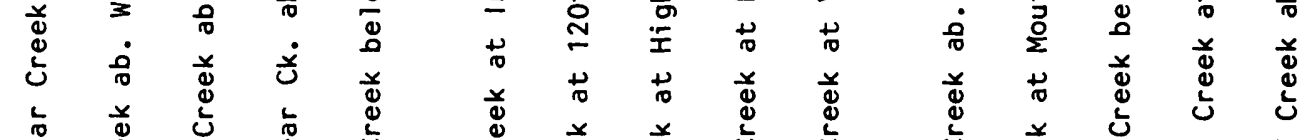

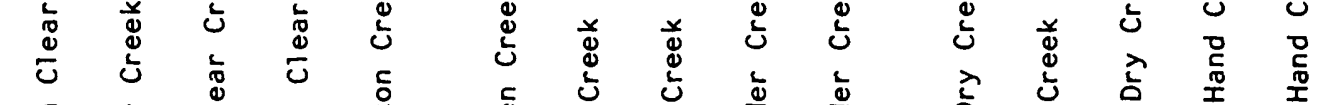

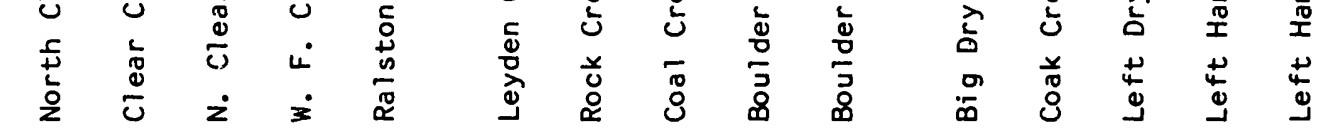

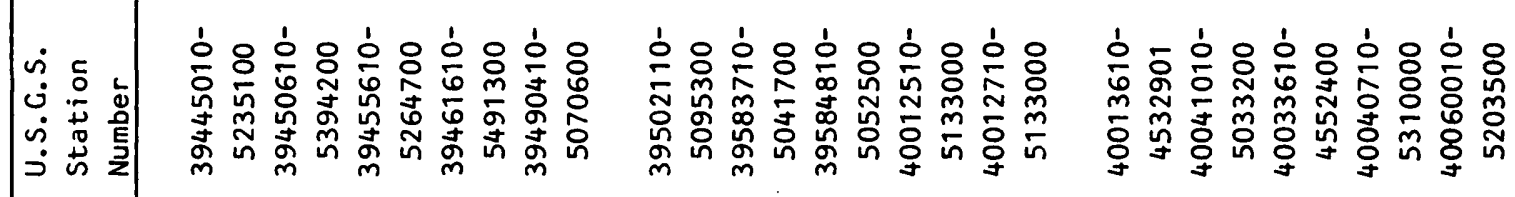

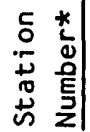

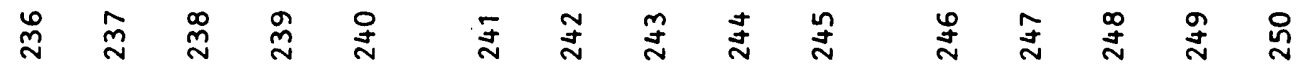




\subsection{SUPPLEMENTAL INFORMATION--Continued}

12.1 Surface-Water Station index

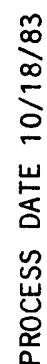

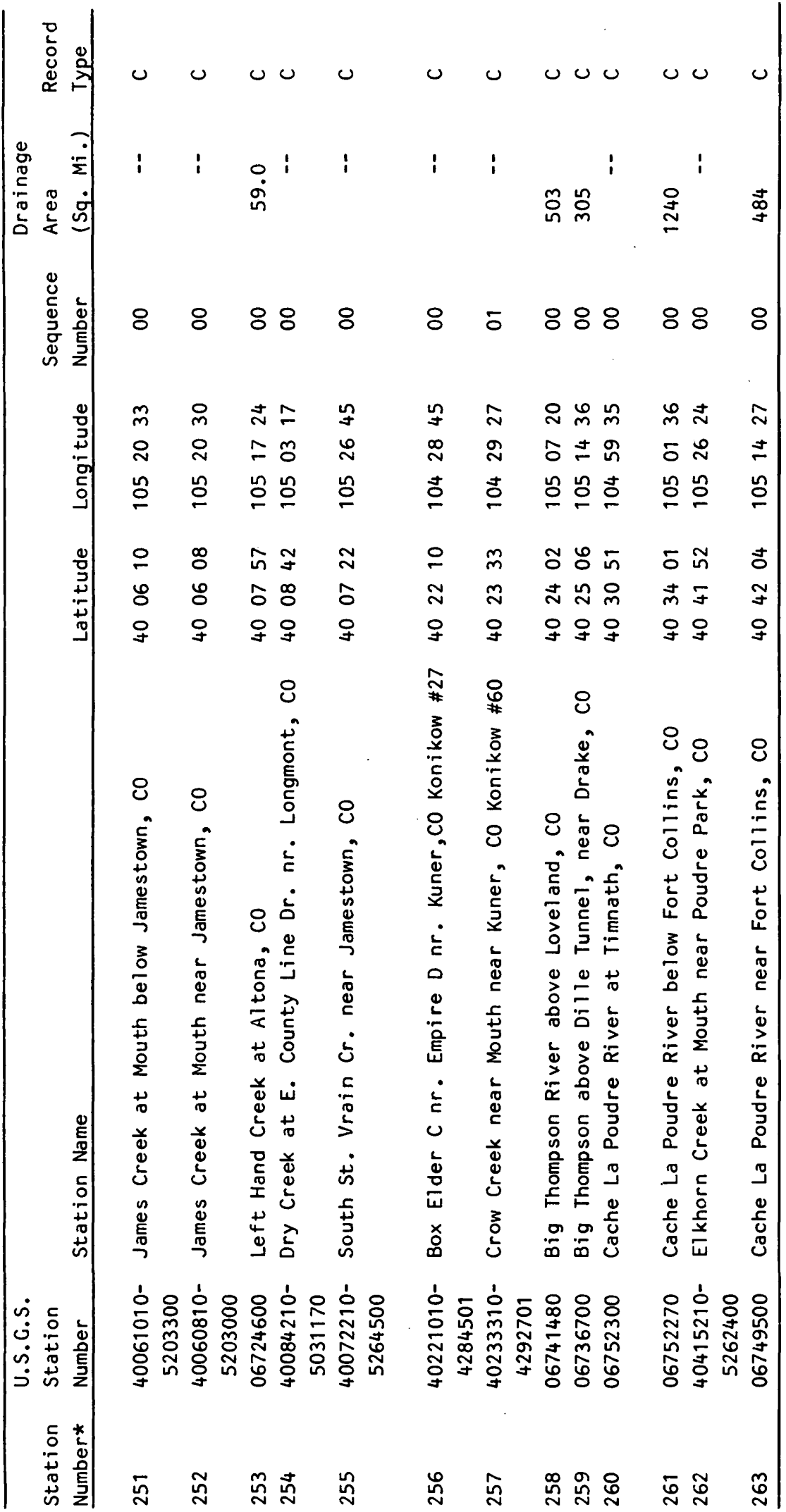

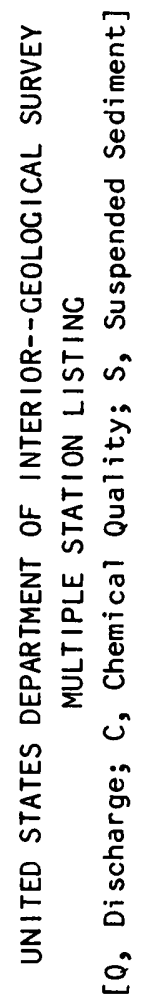




\subsection{SUPPLEMENTAL INFORMATION--Continued}

12.2 Summary of Surface Areas, Capacities, and Uses of Selected Lakes and Reservoirs

[C, Cooling for Thermal Power; FC, Flood Control; I, Irrigation;

$P$, Power; R, Recreation; WS, Water Supply]

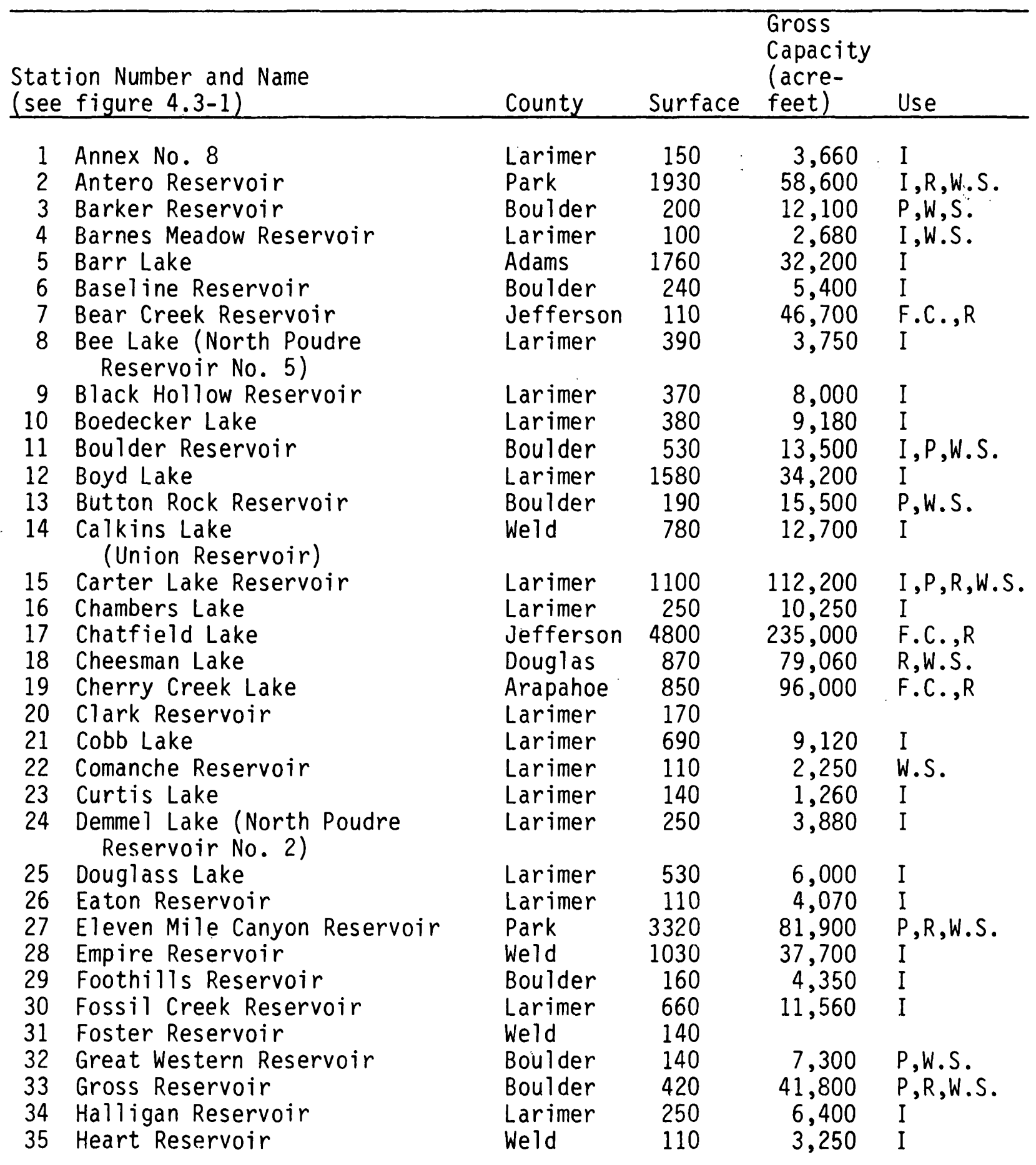




\subsection{SUPPLEMENTAL INFORMATION--Continued}

12.2 Summary of Surface Areas, Capacities, and Uses of Selected Lakes and Reservoirs

[C, Cooling for Thermal Power; FC, Flood Control; I, Irrigation;

$P$, Power; R, Recreation; WS, Water Supply]

\begin{tabular}{|c|c|c|c|c|c|}
\hline \multicolumn{2}{|c|}{$\begin{array}{l}\text { Station Number and Name } \\
\text { (see figure } 4.3-1 \text { ) }\end{array}$} & County & Surface & $\begin{array}{l}\text { Gross } \\
\text { Capacity } \\
\text { (acre- } \\
\text { feet) }\end{array}$ & Use \\
\hline 36 & Highland No. 2 Reservoir & Boulder & 150 & 3,770 & I \\
\hline 37 & Horse Creek Reservoir & Adams & 710 & 17,000 & I \\
\hline 38 & Horseshoe Lake & Larimer & 610 & 8,300 & $I, R$ \\
\hline 39 & Horsetooth Reservoir & Larimer & 1900 & 151,000 & $I, R, W . S$. \\
\hline 40 & Indian Creeek Reservoir & Larimer & 120 & 1,910 & I \\
\hline 41 & Ish Reservoir & Boulder & 310 & 7,100 & $I, R$ \\
\hline 42 & Jackson Reservoir & Weld & 2430 & 36,600 & $I$ \\
\hline 43 & Lake Estes & Larimer & 170 & 3,250 & $I, P$ \\
\hline 44 & Lake Loveland & Larimer & 450 & 14,200 & $I, P, W . S$. \\
\hline 45 & Left-hand Valley Reservoir & Boulder & 110 & 1,800 & $I, R$ \\
\hline 46 & Lonetree Reservoir & Larimer & 470 & 9,200 & $I, R$ \\
\hline 47 & Long Draw Reservoir & Larimer & 340 & 11,000 & I \\
\hline 48 & Lon Hagler Reservoir & Larimer & 150 & 5,300 & $I, R$ \\
\hline 49 & Loveland Reservoir & Larimer & 140 & 2,300 & $I, R$ \\
\hline 50 & Lower Latham Reservoir & Weld & 710 & 6,100 & F.C.,I, R \\
\hline 51 & Marshall Lake & Boulder & 210 & 10,300 & \\
\hline 52 & Marston Lake & Denver & 650 & 19,800 & W.S. \\
\hline 53 & McClellan Reservoir & Arapahoe & 190 & 6,000 & W.S. \\
\hline 54 & McIntosh Lake & Boulder & 250 & 2,450 & I \\
\hline 55 & Milton Reservoir & Weld & 850 & 31,100 & I \\
\hline 56 & Newell Lake & Weld & 140 & & \\
\hline 57 & North Poudre Reservoir No. 3 & Larimer & 160 & 2,760 & I \\
\hline 58 & North Poudre Reservoir No. 4 & Larimer & 100 & 1,390 & I \\
\hline 59 & North Poudre Reservoir No. 6 & Larimer & 480 & 10,200 & I \\
\hline 60 & Panama Reservoir No. 1 & Boulder & 330 & 3,900 & I \\
\hline 61 & Park Creek Reservoir & Larimer & 240 & 7,400 & I \\
\hline 62 & Prospect Reservoir & Weld & 380 & 5,700 & I \\
\hline 63 & Ralston Reservoir & Jefferson & 260 & 11,300 & P,W.S. \\
\hline 64 & Riverside Reservoir & Weld & 3650 & 57,600 & I \\
\hline 65 & $\begin{array}{l}\text { Rocky Ridge Lake (Water Supply } \\
\text { \& Storage Reservoir No. 1) }\end{array}$ & Larimer & 220 & 4,730 & I \\
\hline 66 & Seaman Reservoir & Larimer & 120 & 6,000 & I \\
\hline 67 & Seeley Lake & Weld & 130 & & \\
\hline 68 & Sixmile Reservoir & Boulder & 100 & 1,500 & I \\
\hline 69 & Sloan Lake & Denver & 180 & 990 & $I, R$ \\
\hline 70 & Standley Lake & Jefferson & 1230 & 50,000 & $I, R, W . S$. \\
\hline
\end{tabular}


[C, Cooling for Thermal Power; FC, Flood Control; I, Irrigation;

$P$, Power; R, Recreation; WS, Water Supply]

\begin{tabular}{|c|c|c|c|c|c|}
\hline \multicolumn{2}{|c|}{$\begin{array}{l}\text { Station Number and Name } \\
\text { (see figure } 4.3-1 \text { ) }\end{array}$} & County & Surface & $\begin{array}{l}\text { Gross } \\
\text { Capacity } \\
\text { (acre- } \\
\text { feet) }\end{array}$ & Use \\
\hline 71 & Terry Lake & Boulder & 320 & 8,140 & $I, R$ \\
\hline 72 & Timnath Reservoir & Larimer & 610 & 9,530 & \\
\hline 73 & Valmont Reservoir & Boulder & 290 & 11,200 & F.C. \\
\hline 74 & Warren Lake & Larimer & 150 & 2,300 & I \\
\hline 75 & $\begin{array}{l}\text { Water Supply and Storage } \\
\text { Reservoir No. } 3\end{array}$ & Larimer & 200 & 4,830 & I \\
\hline 76 & Welch Reservoir & Larimer & 470 & 6,700 & I \\
\hline 77 & Wellington Lake & Park & 170 & 4,400 & I \\
\hline 78 & Windsor Lake & Weld & 190 & 1,300 & $I, R$ \\
\hline 79 & Windsor Reservoir & Weld & 850 & 10,000 & $I, W . S$. \\
\hline 80 & Woods Lake & Weld & 160 & 2,900 & \\
\hline
\end{tabular}




\subsection{SUPPLEMENTAL INFORMATION--Continued}

12.3 Specific Conductance of Water Samples from Selected Surface-Water Stations

[Microhoms per centimeter at $25^{\circ}$ Celsius]

\begin{tabular}{|c|c|c|c|c|c|}
\hline $\begin{array}{l}\text { Station number } \\
\text { (see fig. } 7.2-1 \text { ) }\end{array}$ & $\begin{array}{l}\text { Number of } \\
\text { samples }\end{array}$ & Average & Minimum & Maximum & $\begin{array}{l}\text { Standard } \\
\text { deviation }\end{array}$ \\
\hline $\begin{array}{r}1 \\
2 \\
3 \\
4 \\
8 \\
9 \\
10 \\
11 \\
23 \\
28 \\
29 \\
35 \\
39 \\
42 \\
56 \\
66 \\
67 \\
85 \\
109 \\
117 \\
121 \\
122 \\
124 \\
126 \\
131 \\
138 \\
140 \\
142 \\
143 \\
147 \\
148 \\
162 \\
167 \\
173 \\
176 \\
177 \\
179 \\
183 \\
187 \\
190 \\
200 \\
214 \\
215\end{array}$ & $\begin{array}{r}35 \\
36 \\
34 \\
36 \\
48 \\
48 \\
46 \\
48 \\
22 \\
88 \\
51 \\
24 \\
19 \\
9 \\
80 \\
13 \\
13 \\
10 \\
255 \\
108 \\
133 \\
57 \\
36 \\
53 \\
14 \\
15 \\
54 \\
24 \\
210 \\
1 \\
6 \\
186 \\
70 \\
28 \\
143 \\
79 \\
220 \\
258 \\
47 \\
258 \\
168 \\
2 \\
15\end{array}$ & $\begin{array}{r}225 \\
368 \\
271 \\
217 \\
140 \\
114 \\
89 \\
202 \\
315 \\
202 \\
419 \\
189 \\
1,292 \\
361 \\
176 \\
1,082 \\
1,836 \\
278 \\
964 \\
34 \\
60 \\
70 \\
1,400 \\
1,331 \\
183 \\
62 \\
234 \\
817 \\
1,378 \\
79 \\
52 \\
1,942 \\
62 \\
45 \\
109 \\
426 \\
1,661 \\
1,459 \\
895 \\
1,459 \\
1,705 \\
20,600 \\
194\end{array}$ & $\begin{array}{r}65 \\
120 \\
85 \\
50 \\
50 \\
60 \\
50 \\
100 \\
200 \\
80 \\
190 \\
80 \\
190 \\
190 \\
80 \\
750 \\
669 \\
155 \\
225 \\
18 \\
25 \\
25 \\
400 \\
250 \\
43 \\
30 \\
95 \\
320 \\
315 \\
-.- \\
50 \\
325 \\
26 \\
17 \\
27 \\
45 \\
277 \\
370 \\
660 \\
370 \\
598 \\
17,200 \\
155\end{array}$ & $\begin{array}{r}340 \\
620 \\
370 \\
300 \\
280 \\
275 \\
210 \\
420 \\
450 \\
400 \\
650 \\
1,450 \\
2,200 \\
593 \\
330 \\
2,800 \\
2,590 \\
350 \\
1,470 \\
73 \\
105 \\
140 \\
1,820 \\
1,900 \\
380 \\
90 \\
600 \\
1,300 \\
2,080 \\
-- \\
60 \\
3,000 \\
100 \\
60 \\
285 \\
775 \\
2,350 \\
2,520 \\
1,180 \\
2,520 \\
2,870 \\
24,000 \\
275\end{array}$ & $\begin{array}{r}72.8 \\
137.2 \\
79.8 \\
217.9 \\
51.6 \\
44.6 \\
49.7 \\
62.8 \\
70.2 \\
70.6 \\
124.1 \\
272.6 \\
490.0 \\
148.9 \\
51.7 \\
529.7 \\
1025.1 \\
58.0 \\
319.1 \\
12.5 \\
17.1 \\
25.5 \\
366.9 \\
362.2 \\
94.6 \\
18.9 \\
118.3 \\
299.1 \\
314.9 \\
-.- \\
4.1 \\
518.7 \\
18.9 \\
11.6 \\
53.8 \\
225.2 \\
375.5 \\
377.8 \\
115.4 \\
377.8 \\
336.3 \\
4808.3 \\
26.4\end{array}$ \\
\hline & & 110 & & & \\
\hline
\end{tabular}


[Microhoms per centimeter at $25^{\circ}$ Celsius]

\begin{tabular}{|c|c|c|c|c|c|}
\hline $\begin{array}{l}\text { Station number } \\
\text { (see fig. } 7.2-1 \text { ) }\end{array}$ & $\begin{array}{c}\text { Number of } \\
\text { samples }\end{array}$ & Average & Minimum & Maximum & $\begin{array}{l}\text { Standard } \\
\text { deviation }\end{array}$ \\
\hline 216 & 2 & 155 & 134 & 176 & 29.7 \\
\hline 222 & 2 & 42 & 35 & 50 & 10.6 \\
\hline 223 & 1 & 264 & -- & --- & -- \\
\hline 224 & 4 & 92 & 70 & 107 & 15.9 \\
\hline 225 & 4 & 103 & 96 & 113 & 8.0 \\
\hline 226 & 2 & 74 & 61 & 86 & 17.7 \\
\hline 227 & 4 & 232 & 114 & 278 & 78.9 \\
\hline 228 & 2 & 76 & 55 & 97 & 29.7 \\
\hline 229 & 4 & 65 & 56 & 71 & 6.6 \\
\hline 230 & 4 & 112 & 83 & 139 & 23.5 \\
\hline 231 & 4 & 203 & 107 & 266 & 68.0 \\
\hline 232 & 19 & 347 & 190 & 450 & 67.0 \\
\hline 233 & 14 & 862 & 480 & 950 & 123.0 \\
\hline 234 & 7 & 285 & 120 & 420 & 98.8 \\
\hline 235 & 2 & 337 & 334 & 340 & 4.2 \\
\hline 236 & 4 & 447 & 130 & 587 & 212.0 \\
\hline 237 & 3 & 173 & 170 & 180 & 5.5 \\
\hline 238 & 2 & 655 & 590 & 719 & 91.2 \\
\hline 239 & 4 & 766 & 140 & 1,000 & 417.9 \\
\hline 240 & 2 & 971 & 950 & 992 & 29.7 \\
\hline 241 & 2 & 1,185 & 1,000 & 1,370 & 261.6 \\
\hline 242 & 1 & 1,890 & -.- & -.- &.-- \\
\hline 243 & 14 & 1,082 & 800 & 2,400 & 473.5 \\
\hline 244 & 14 & 183 & 43 & 380 & 94.6 \\
\hline 246 & 1 & 2,250 & -- & -- & -.- \\
\hline 247 & 1 & 969 & --- & --- & --- \\
\hline 248 & 2 & 4,400 & 4,400 & 4,400 & --- \\
\hline 249 & 53 & 40 & 20 & 72 & 9.6 \\
\hline 250 & 53 & 147 & 58 & 260 & 57.2 \\
\hline 251 & 53 & 65 & 27 & 220 & 64.6 \\
\hline 253 & 97 & 148 & 31 & 360 & 77.4 \\
\hline 254 & 1 & 1,780 & -- &.- &.- \\
\hline 255 & 13 & 51 & 28 & 68 & 13.6 \\
\hline 256 & 1 & 1,900 & -- & -- & -- \\
\hline 257 & 1 & 2,400 &.-- & -.- & -.- \\
\hline 258 & 28 & 622 & 68 & 1,600 & 431.9 \\
\hline 259 & 115 & 65 & 28 & 188 & 22.9 \\
\hline 260 & 123 & 515 & 150 & 2,400 & 713.0 \\
\hline 261 & 48 & 577 & 80 & 867 & 234.1 \\
\hline 262 & 1 & 106 & -.. & -- & -.. \\
\hline 263 & 24 & 78 & 34 & 130 & 30.5 \\
\hline
\end{tabular}

12.0 SUPPLEMENTAL INFORMATION--Continued 12.3 Specific Conductance of Water Samples from Selected Surface-Water Stations 


\subsection{SUPPLEMENTAL INFORMATION--Continued}

12.4 Trace-Element Concentrations in Water Samples from Selected Surface-Water Stations Exceeding the Recommended Water-Quality Criteria

\begin{tabular}{|c|c|c|c|c|c|c|c|c|c|c|}
\hline \multirow{2}{*}{$\begin{array}{l}\text { Sampling } \\
\text { Station No. } \\
\text { (see fig. } \\
7.7-1 \text { ) }\end{array}$} & \multicolumn{2}{|c|}{$\begin{array}{l}\text { No. of } \\
\text { samples }\end{array}$} & \multicolumn{2}{|c|}{ Average } & \multicolumn{2}{|c|}{ Minimum } & \multicolumn{2}{|c|}{ Maximum } & \multicolumn{2}{|c|}{$\begin{array}{l}\text { Standard } \\
\text { Deviation }\end{array}$} \\
\hline & $\begin{array}{l}\text { Dis- } \\
\text { solved }\end{array}$ & Total & $\begin{array}{l}\text { Dis- } \\
\text { solved }\end{array}$ & Tota 1 & $\begin{array}{l}\text { Dis- } \\
\text { solved }\end{array}$ & Total & $\begin{array}{l}\text { Dis- } \\
\text { solved }\end{array}$ & Total & $\begin{array}{l}\text { Dis- } \\
\text { solved }\end{array}$ & Total \\
\hline \multicolumn{11}{|c|}{ Cadmium } \\
\hline $\begin{array}{r}11 \\
215 \\
236 \\
239 \\
252\end{array}$ & 16 & $\begin{array}{r}10 \\
6 \\
2 \\
2 \\
1\end{array}$ & 6.6 & $\begin{array}{l}10 \\
\frac{20}{20} \\
\frac{20}{20} \\
\end{array}$ & 0.0 & $\begin{array}{r}0.0 \\
0.0 \\
20 \\
20\end{array}$ & 40 & $\frac{\frac{60}{20}}{20}$ & 10.4 & $\begin{array}{r}18.7 \\
8.2 \\
0.0 \\
0.0\end{array}$ \\
\hline
\end{tabular}

Copper

\begin{tabular}{|c|c|c|c|c|c|c|c|c|c|c|}
\hline $\begin{array}{r}42 \\
66 \\
236 \\
239\end{array}$ & & $\begin{array}{r}17 \\
6 \\
2 \\
2\end{array}$ & & $\begin{array}{r}20 \\
\frac{60}{220} \\
40\end{array}$ & & $\begin{array}{c}4.0 \\
20 \\
130 \\
20\end{array}$ & & $\frac{\frac{90}{150}}{\underline{300}}$ & & $\begin{array}{r}22.5 \\
45.9 \\
120.2 \\
21.2\end{array}$ \\
\hline \multicolumn{11}{|c|}{ Lead } \\
\hline $\begin{array}{r}11 \\
42 \\
66 \\
167 \\
176 \\
177 \\
215 \\
236 \\
239 \\
252\end{array}$ & 15 & $\begin{array}{r}10 \\
17 \\
6 \\
1 \\
1 \\
24 \\
6 \\
2 \\
2 \\
1\end{array}$ & 84 & $\begin{array}{l}\frac{\frac{110}{120}}{\frac{340}{200}} \\
\frac{200}{9.3} \\
\frac{200}{\frac{200}{130}} \\
\frac{200}{130}\end{array}$ & 0.0 & $\begin{array}{l}0.0 \\
\frac{200}{200} \\
\frac{50}{10}\end{array}$ & $\underline{370}$ & $\begin{array}{l}\frac{480}{530} \\
700 \\
120 \\
\frac{200}{200} \\
\underline{200} \\
\end{array}$ & 139.8 & $\begin{array}{r}23.8 \\
0.0 \\
0.0 \\
106.1\end{array}$ \\
\hline
\end{tabular}




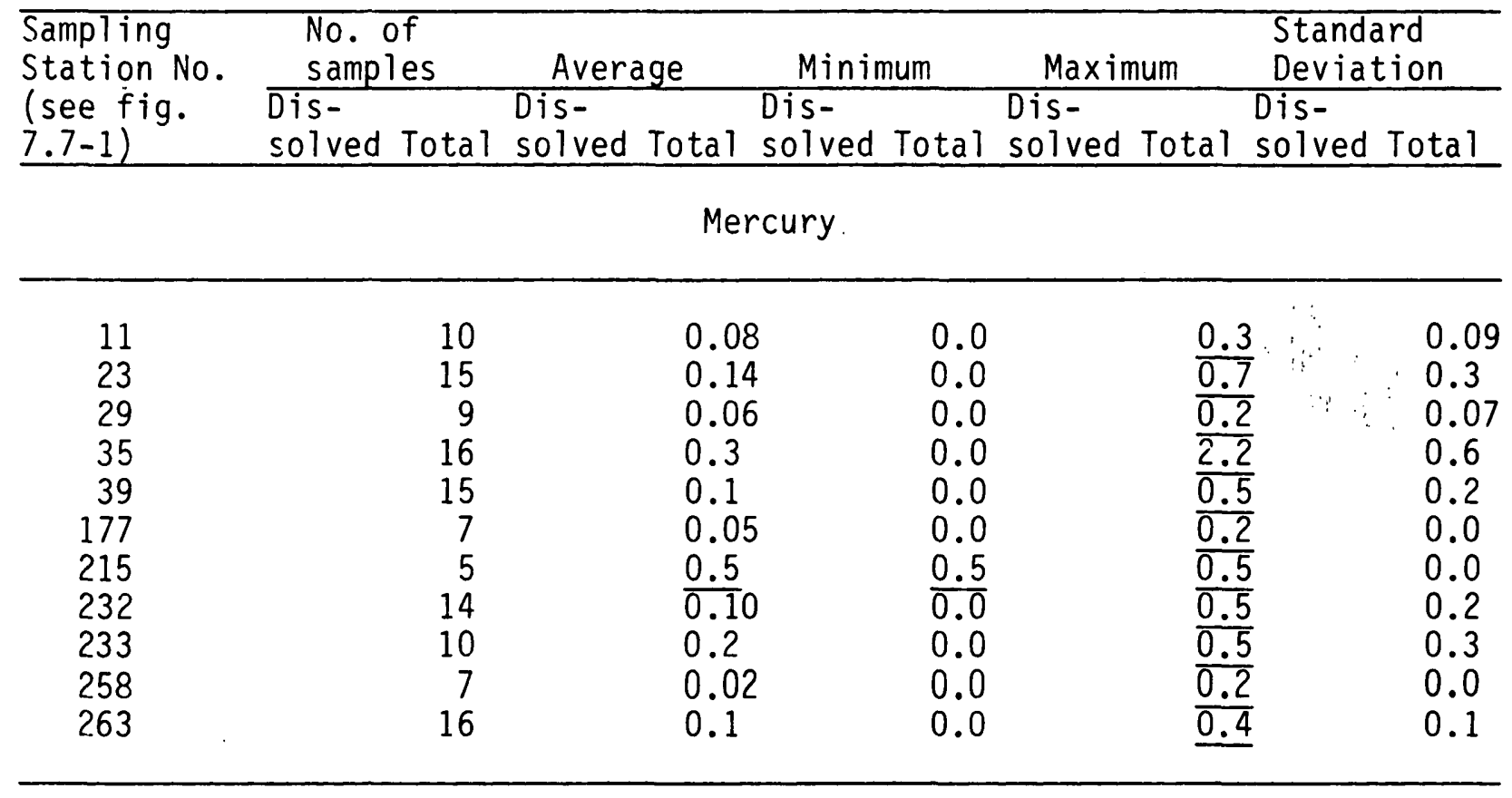

Selenium

\begin{tabular}{|c|c|c|c|c|c|c|c|c|c|c|}
\hline $\begin{array}{l}236 \\
238 \\
242 \\
258\end{array}$ & $\begin{array}{l}3 \\
1 \\
1\end{array}$ & 2 & $\frac{\frac{16}{24}}{\underline{35}}$ & $\begin{array}{l}37 \\
25\end{array}$ & 3 & $\begin{array}{l}6 \\
1.0\end{array}$ & 27 & $\begin{array}{r}67 \\
120\end{array}$ & 12.2 & $\begin{array}{l}43.1 \\
43.0\end{array}$ \\
\hline \multicolumn{11}{|c|}{ Zinc } \\
\hline $\begin{array}{r}66 \\
236\end{array}$ & & $\begin{array}{l}6 \\
2\end{array}$ & & $\begin{array}{r}360 \\
1700 \\
\end{array}$ & & $\begin{array}{r}50 \\
580\end{array}$ & & $2 \frac{830}{2900}$ & & $\begin{array}{r}261.2 \\
1640.5\end{array}$ \\
\hline
\end{tabular}

\subsection{SUPPLEMENTAL INFORMATION--Continued}

12.4 Trace-Element Concentrations in Water Samples from Selected Surface-Water Stations Exceeding the Recommended Water-Quality Criteria 


\subsection{REFERENCES}

\subsection{References Cited}

Boyd, David, 1897, Irrigation near Greeley, Colorado: U.S. Geological Survey Water Supply Paper 9, $90 \mathrm{p}$.

Bryant, Bruce, and Wobus, R. A., 1975, Preliminary geologic map of the south-western quarter of the Denver $1^{\circ} \times 2^{\circ}$ quadrangle: U.S. Geological Survey Open-File Report 75-340, scale 1:250,000.

Carpenter, L. G., 1911, Seepage and return waters: Colorado Agricultural Experiment Station Bulletin 180, Part 1, 70 p.; Part 2 and Part 3 $148 \mathrm{p}$.

Chronic, John, and Chronic, Halka, 1972, Prairie peak and plateau: Denver, Colorado Geological Survey Bulletin 32, $126 \mathrm{p}$.

Cochran, B. J., Hodges, H. E., Livingston, R. K., and Jarrett, R. D., 1979, Rainfall-runoff data from small watersheds in Colorado, October 1974 through September 1977: U.S. Geological Survey Open-File Report 79-1261, 673 p.

Cochran, B. J., Minges, D. R., Jarrett, R. D., and Veenhuis, J. E., 1983, Rainfall-runoff data from small watersheds in Colorado, October 1977 through September 1980: U.S. Geological Survey Open-File Report 82-873, 748 p.

Colorado Department of Health, Water Quality Control Commission, 1979, Regulations establishing basic standards and an antidegradation standard and establishing a system for classifying state waters, for assigning standards, and for granting temporary modifications: Denver, $40 \mathrm{p}$.

Colorado Mined Land Reclamation Division, Inactive Mine Program, 1982, Their silent profileInactive coal and metal mines of Colorado, v. 2: Denver, Colorado Department of Natural Resources.

Colorado Land-Use Commission, 1974, Colorado land-use map folio: Denver, Colorado Land Use Commission, 12 sheets.

Craig, G. S., Jr., and Rankl, J. G., 1978, Analysis of runoff from small drainage basins in Wyoming: U.S. Geological Survey Water-Supply Paper 2056, 70 p.

Danielson, T. W., 1975, Lakes in the greater Denver area, Front Range Urban Corridor, Colorado: U.S. Geological Survey, Miscellaneous Investigations Series, Map I-856-B.

Davies, P. H., and Goettl, J. P., Jr., 1976, Aquatic life-Water Quality recommendations for heavy metal and other inorganic toxicants in fresh water: Denver, Colorado Division of Wildlife, 29 p.

Dosch, T. R., 1982a, Flood-prone areas in Elbert County, Colorado: Elbert County Land Use Administration, map, Scale 1:12,000.

1982b, Flood-prone areas in Elbert County, Colorado-Technical Addendum, Kiowa, Colorado, Elbert County Board Land Use Administration, $41 \mathrm{p}$.

Ducret, G. L., Jr., and Hodges, H. E., 1972, Rainfall-runoff data from small watersheds in Colorado, June 1968 through September 1971: Denver, Colorado Water Conservation Board Basic-Data Release 27, $301 \mathrm{p}$.

1975, Rainfall-runoff data from small watersheds in Colorado, October 1971 through September 1974: Denver, Colorado Water Conservation Board Basic-Data Release 38, 539 p.

Engelke, M. J., Roth, D. K., and others, 1981, Hydrology of Area 7, Eastern coal province, Ohio: U.S. Geological Survey Water-Resources Investigations 81-815, $60 \mathrm{p}$.

Fenneman, N.M., 1946, Physical divisions of the United States: U.S. Geological Survey, scale $1: 7,000,000$.

Ficke, J. F., and Danielson, T. W., 1973, Lakes in the Boulder-Fort Collins-Greeley area, Front Range Urban Corridor, Colorado: U.S. Geological Survey Miscellaneous Investigations Series, Map I-855-A.

Freudenthal, P.B., 1979, Water quality data for the Hanna and Carbon Basins, Wyoming: U.S. Geological Survey Open-File Report 79-1277, $41 \mathrm{p}$.

Goolsby, S. M., Reade, N.B.S., 1978, Map of licensed coal mines in Colorado as of June 1, 1978: Denver, Colorado Geological Survey, Map Series 12.

Grozier, R. U., McCain, J. F., Lang, L. F., and Merriman, D. C., 1976, The Big Thompson River Flood of July 31-August 1, 1976, Larimer County, Colorado: Denver, Colorado Water Conservation Board Flood publication, pt 66, $12 \mathrm{p}$.

Hall, D. C., Hillier, D. E., Nickum, Edward, and 
Darrance, W. G., 1981, Effects of residential wastewater-treatment systems on groundwater quality, in west-central Jefferson County, Colorado: U.S. Geological Survey Water-Resources Investigations, Open-File Report 81-73, 65 p.

Hansen, W. R., Chronic, John, and Matclock, John, 1978, Climatography of the Front Range Urban Corridor and vicinity, Colorado: U.S. Geological Survey Professional Paper 1019, $59 \mathrm{p}$.

Heil, R. D., Romaine, D. S., Moreland, D. C., Dansdill, R. K., Montgomery, R. H., and Cipra, J. E., 1977, Soils of Colorado: Ft. Collins, Colorado State University Experiment Station, Bulletin 5665, $39 \mathrm{p}$.

Hem, J. D., 1970, Study and interpretation of the chemical characteristics of natural water (2nd ed.): U.S. Geological Survey Water-Supply Paper 1473, $363 \mathrm{p}$.

Hillier, D.E., Brogden, R.E., and Schneider, P.A., Jr., 1978, Hydrology of the Arapahoe aquifer in the Englewood-Castle Rock area south of Denver, Denver basin, Colorado: U.S. Geological Survey Miscellaneous Investigations Series Map I-1043.

Hurr, R. T., Schneider, P. A., Jr., and Minges, D. R., 1975, Hydrology of the South Platte River valley, northeastern Colorado: U.S. Geological Survey Circular 28, 24 p.

Kircher, J. E., 1981a, Sediment analysis for selected sites on the South Platte River in Colorado and Nebraska, and the North Platte and Platte River in Nebraska-Suspended sediment, bedload, and bed material: U.S. Geological Survey Open-File Report 81-207, $48 \mathrm{p}$.

1981b, Sediment transport and effective discharge of the North Platte, South Platte, and Platte rivers, Nebraska: U.S. Geological Survey Open-File Report 81-53, 26 p.

1982, Interpretation of sediment data for the South Platte River in Colorado and Nebraska, and the North Platte and Platte Rivers in Nebraska: U.S. Geological Survey Professional Paper 1277-D, p.

Kirkham, R.M., and Ladwig, L.R., 1979, Coal Resources of the Denver and Cheyenne Basins, Colorado: Denver, Colorado Geological Survey, Resource Series 5, pt. 5, 70 p.

Kirkham, R. M., and Ladwig, L. R., 1980,
Energy Resources of the Denver and Cheyenne Basins, Colorado, resource characteristics, Development potential, and environmental problems: Denver, Colorado Geological Survey, Environmental Geology Series 12, 258 p.

Kiteley, L.W., 1978, Stratigraphic sections of cretaceous rocks of the northern Denver basin, northeastern Colorado and southeastern Wyoming: U.S. Geological Survey Chart OC-78, 1 sheet, scale not given.

Lang, L. F., and McCain, J. G., 1975, Index to Flood-Plain Information in Colorado: U.S. Geological Survey open-file report map.

Leroy, L.W., 1946, Stratigraphy of the GoldenMorrison area, Jefferson County, Colorado: Colorado School of Mines Quarterly, v. 41, no. $2,115 \mathrm{p}$.

Livingston, R. K., 1970, Evaluation of the streamflow data program in Colorado: U.S. Geological Survey open-file report, $72 \mathrm{p}$.

Lowham, H. W., 1976, Techniques for estimating flow characteristics of Wyoming streams: U.S. Geological Survey Water-Resources Investigations 76-112, $83 \mathrm{p}$.

McCain, J. F., and Jarrett, R. D., 1976, Manual for estimating flood characteristics of natural-flow streams in Colorado: Denver, Colorado Water Conservation Board Technical Manual no. 1, $68 \mathrm{p}$.

McConaghy, J.A., Chase, G.H., Boettcher, A.J., and Major, T.J., 1964, Hydrogeologic data of the Denver basin, Denver, Colorado: Colorado Water Conservation Board Basic-Data Report $15,224 \mathrm{p}$.

McWhorter, D.B., Rowe, J.W., VanLiew, M.W., Chandler, R.L., Skogerboe, R.K., Sunada, D.K., and Skogerboe, G.B., 1977, Surface and subsurface water-quality hydrology in surface mined watersheds, pt. $1,313 \mathrm{p}$.

Major, T. J., Robson, S. G., and Zawistowski, Stanley, 1983, Hydrologic data from parts of the Denver basin: U.S. Geological Survey Open-File Report 83-274 (in press).

Minges, D. R., 1983, Selected hydrologic characteristics of the South Platte River in the vicinity of the proposed Narrows Reservoir near Fort Morgan, Colorado: U.S. Geological Survey Water-Resources Investigations 82-4071, $25 \mathrm{p}$.

Minges, D. R., and Livingston, R. K., 1983, Flood characteristics of small rural watersheds in the 
plains region of eastern Colorado: U.S. Geological Survey Water-Resources Investigations 83-xxx, xx p.

Moran, R. E., and Wentz, D. A., 1974, Effects of metal-mine drainage on water quality in selected areas of Colorado, 1972-73: Denver, Colorado Water Conservation Board Water Resources Circular 25, $250 \mathrm{p}$.

Mundorff, J. C., 1964, Fluvial sediment in Kiowa Creek basin, Colorado: U.S. Geological Survey Water-Supply Paper 1798-A, 70 p.

1968, Fluvial sediment in the drainage area of K-79 Reservoir, Kiowa Creek basin, Colorado: U.S. Geological Survey Water-Supply Paper 1798-D, $26 \mathrm{p}$.

Office of Surface Mining, 1979, Surface coal mining and reclamation operators-Permanent regulatory programs: Federal Register, v. 44, no. 50 , book 3, p. 15311-15463.

Parshall, R. L., 1922, Return of seepage water to the lower South Platte River in Colorado: Ft. Collins, Colorado Agricultural Experiment Station Bulletin 279, $72 \mathrm{p}$.

Ragsdale, J. O., 1982, Ground-water levels in Wyoming, 1971 through part of 1980: U.S. Geological Survey Open-File Report 82-859, $200 \mathrm{p}$.

Repplier, F. N., Healy, F. C., Collins, D. B., and Longmire, P. A., 1981, Atlas of ground water quality in Colorado: Denver, Colorado Geological Survey, Map Series no. 16, 7 sheets, scale 1:500,000.

Robson, S. G., and Romero, J. C., 1981a, Geologic structure, hydrology, and water quality of the Dawson aquifer in the Denver basin, Colorado: U.S. Geological Survey Hydrologic Investigations Atlas HA-643, 3 sheets, scale 1:250,000.

Robson, S.G., and Romero, J.C., 1981b, Geologic structure, hydrology, and water quality of the Denver aquifer in the Denver basin, Colorado: U.S. Geological Survey Hydrologic Investigations Atlas HA-646, 3 sheets, 1:500,000.

Robson, S. G., Romero, J. C., and Zawistowski, Stanley, 1981, Geologic structure hydrology, and water quality of the Arapahoe aquifer in the Denver basin, Colorado: U.S. Geological Survey Hydrologic Investigations Atlas HA-647, 3 sheets, scale 1:500,000.

Robson, S. G., Wacinski, Andrew, Zawistowski, Stanley, and Romero, J. C., 1981, Geologic structure, hydrology, and water quality of the
Laramie-Fox Hills aquifer in the Denver basin, Colorado: U.S. Geological Survey Hydrologic Investigations Atlas HA-650, 3 sheets, scale 1:500,000.

Romero, J. C., 1976, Ground-water resources of the bedrock aquifers of the Denver basin Colorado: Denver, Colorado Division of Water Resources, 12 plates, $109 \mathrm{p}$.

Searcy, J. K., 1959, Flow-duration curves, manual of hydrology-Part 2. Low-flow techniques: U.S. Geological Survey Water-Supply Paper 1542-A, $33 \mathrm{p}$.

Smith, R. O., Schneider, P. A., and Petri, L. R., 1964, Ground-water resources of the South Platte River basin in western Adams and southwestern Weld Counties, Colorado: U.S. Geological Survey Water Supply Paper 1658, $132 \mathrm{p}$.

Soister, P. E., 1974, A preliminary report on a zone containing thick lignite beds, Denver basin, Colorado: U.S. Geological Survey Open-File Report 74-27, 64 p., geologic map scale 1:250,000.

1982, Colorado lignite for underground coal gasifification, in Hudson, S. R., ed., Proceedings of the 8th Underground Coal Symposium: Livermore, Calif., Sandia National Laboratory, August 15, 1982, 10 p.

Trimble, D.E., 1980, The geologic history of the Great Plains: U.S. Geological Survey Bulletin 1493, 55 p.

Tweto, Ogden, 1979, compiler, Geologic map of Colorado: U.S. Geological Survey, scale 1:500,000.

U.S. Department of Agriculture, 1976, General soil map, Colorado: U.S. Soil Conservation Service, scale 1:500,000.

1981, General soil map, Albany County, Wyoming: U.S. Soil Conservation Service, scale 1:253,440.

U.S. Census Bureau, 1982, 1980 Census of population, General population characteristics, Colorado, v. 1, Chapter B, part 7, 190 p.

U.S. Environmental Protection Agency, 1976, Quality criteria for water: Washington, D.C., $256 \mathrm{p}$.

U.S. Geological Survey, 1980, Water resources data for Colorado, water year 1979, Missouri River basin, Arkansas River basin, Rio Grande basin: U.S. Geological Survey Water-Data Report CO-79-1, $499 \mathrm{p}$.

U.S. Weather Bureau, 1967, Normal annual 
precipitation, normal May-September precipitation 1931-60, Colorado: U.S. Weather Bureau map, scale 1:500,000, 2 sheets.

Van Voast, W.A., 1974, Hydrologic effects of strip coal mining in southeastern Montanaemphasis, one year of mining near Decker: Helena, Montana Bureau of Mines and Geology, Bulletin 93, 24 p.

Van Voast, W.A., Hedges, R.B., and McDermott, J.J., 1977, Hydrogeologic conditions and projections related to mining near Colstrip, southeastern Montana: Helena, Montana Bureau of Mines and Geology, Bulletin 102, $43 \mathrm{p}$.

Washburne, C. W., 1908, The South Park coal field,
Colorado: U.S. Geological Survey Bulletin 381, p. 307-316.

Wentz, D. A., 1974, Stream quality in relation to mine drainage in Colorado: American Water Resources Association proceedings v. 18, p. 158-172.

Wyoming Department of Environmental Quality, 1979, Water quality rules and regulations, Chapter I, Quality standards for Wyoming surface waters, $20 \mathrm{p}$.

Young, J. F., and Singleton, P. C., 1977, Wyoming general soil map: Laramie, Wyoming, University of Wyoming Agricultural Experiment Station, Research Journal 117, 40 p. 


\subsection{REFERENCES--Continued}

13.2 Selected References

\section{Coal}

Abernathy, R. F., Gibson, F. H., and Frederick, W. H., 1965, Phosphorus, chlorine, sodium, and potassium in United States coals: U.S. Bureau of Mines Report, Investigations 6579, $33 \mathrm{p}$.

Ashley, G. H., 1910, The value of coal land, in, The valuation of public coal lands: U.S. Geological Survey Bulletin 424, p. 1-47.

Atwood, Genevieve, 1975, The strip-mining of western coal: Scientific American, v. 233, no. 6, p. $23-29$.

Berthoud, E. L., 1874, Section of the lignitic strata at Golden City: Hayden Survey, 7th Annual Report, p. 109.

Botsford, M. L., and Botsford, Maria, 1977, An archaeological survey of the Watkins field investigations installation, Section 17, T.3S., R.65W., Adams County, Colorado: U.S. Geological Survey Open-File Report 77-772, $11 \mathrm{p}$.

Cargill, S. M., Olson, A. C., Medlin, A. L., and Carter, M. D., 1976, PACER-Data entry, retrieval, and update for the National Coal Resources Data System (Phase 1): U.S. Geological Survey Professional Paper 978, $107 \mathrm{p}$.

Colorado State Department of Health, Staff, 1970, Water Pollution Control Commission Guidelines for control of water pollution from mine drainage: Denver, Colorado Department of Health, $10 \mathrm{p}$.

Colorado State Planning Commission, 1940, Coal fields of Colorado: Denver, 22 maps.

Colton, R. B., and Lowrie, R. L., 1973, Map showing Boulder-Weld coal field, Colorado: U.S. Geological Survey Miscellaneous Field Studies Map MF-513, scale 1:24,000.

Fender, H. B., Jones, D. C., and Murray, D. K., 1978, Bibilography and index of publications related to coal in Colorado, 1972-1977: Denver, Colorado Geological Survey, Bulletin 41, 54 p.

Grim, E. C., and Hill, R. D., 1974, Environmental protection in surface mining of coal; EPA-670/2-74-093: Cincinnati, Ohio, U.S. Environmental Protection Agency, National Environmental Research Center, 227 p.
Grosvenor, N. E., and others, 1971, Series of 75 index maps showing locations of coal mines in Colorado, revised 1971: Golden, Colorado School of Mines Foundation.

Hatch, J. R., and Swanson, V. E., 1977, Trace elements in Rocky Mountain coals, in D. K. Murray, ed., Geology of Rocky Mountain coal, Proceedings of the 1976 Symposium: Colorado Geological Survey Resource Series 1, p. 143-163.

Henderson, C. W., 1926, Mining in Colorado-A history of discovery, development, and production: U.S. Geological Survey Professional Paper 138, 263 p.

Holt, R. D., 1972, Bibliography, Coal resources in Colorado: Colorado Geological Survey, Bulletin 34-A, $32 \mathrm{p}$.

Imhoff, E. A., 1976, A review of selected laws and governmental programs in Colorado as related to mineral resource management and surface mining: U.S. Geological Survey Open-File Report 76-649.

Imhoff, E. A., Fritz, T. O., and LaFevers, J. R., 1976, A guide to state programs for the reclamation of surface mined areas: U.S. Geological Survey Circular 731, 33 p.

Kim, A. G., and Douglas, L. J., 1973, Gases desorbed from five coals of low gas content: U.S. Bureau of Mines Report Investigations 7768, 9 p.

Kingman, Jerry., 1888, Coal mines of Jefferson County, Colorado: Golden, Colorado School of Mines, M.S. Thesis, IV.

Kirkham, R. M., and Ladwig, L. R., 1977, Preliminary investigation and feasibility study of environmental impact of energy resource development in the Denver basin: Colorado Geological Survey Open-File Report 77-1, 30 p.

Landis, E. R., and Cone, G. C., 1971, Coal resources of Colorado; tabulated by bed: U.S. Geological Survey Open-File Report 71-178, 518 p. (basic survey data is used in compilation of U.S. Geological Survey Bulletin 1072-C, 1959).

Levene, H. D., and Hand, J. W., 1975, Sulfur stays in the ash when lignite burns: Coal Mining and 
Processing, February, p. 46-48.

Linquist, A. E., 1977, Siting potential for coal gasification plants in the United States: U.S. Bureau of Mines Information Circular 8735, $43 \mathrm{p}$.

Lowrie, R. L., 1966, Analysis of the coal industry in Boulder-Weld coal field, Colorado: U.S. Bureau of Mines Report Investigations 6726, $79 \mathrm{p}$.

Martin, G. C., 1910, Coal of the Denver basin, Colorado: U.S. Geological Survey Bulletin 381-C, p. 297-306.

McFarlane, G. C., 1929, Igneous metamorphism of coal beds: Economic Geology, v. 24, p. 1-4.

Sanchez, J. D., 1976, Correlation of shallow lignite beds in the Denver Formation near Watkins, Colorado, using lithologic and gamma ray logs: U.S. Geological Survey Open-File Report 76-279.

Sanchez, J. D., and Hobbs, R. G., 1977, Chemical analysis, physical property tests, and lithologic description of cores and cuttings of lignite and overburden rocks from an area near Watkins, Colorado: U.S. Geological Survey Open-File Report 77-628, 22 p.

Sarnecki, J. C., 1977, Ecology and stratigraphy of some occurrances of peat on the eastern slope of the Front Range, Colorado, in Geological Society America Abstract, v. 9, no. 6, p. 759.

Soister, P. E., 1974, A preliminary report on a zone containing thick lignite beds Denver basin, Colorado: U.S. Geological Survey open-file report, $46 \mathrm{p}$.

Speltz, C. N., 1974, Strippable coal resources of Colorado-Location, tonnage, and characteristics: U.S. Department of the Interior, Bureau of Mines, Preliminary Report 195, 70 p.

Stone, G. H., 1903, Discovery of coal on Turkey Creek: American Geologist, v. 32, p. 132.

U.S. Congress, Office of Technology Assessment, Washington, D.C.: The office, 1981, An assessment of development and production potential of Federal coal leases, IX, $473 \mathrm{p}$.

U.S. Department of Interior, Office of Library Services, 1971, Bibliography of surface mined areas; control and reclamation of environmental damages: January 1, 1960 to June 1970: available as PS203-449 from 5865 Port Royal Road, National Technical Information Service, Springfield, Virginia 22151.

U.S. General Accounting Office, Energy and
Minerals Division, 1977, U.S. Coal Development-Promises, uncertainties, EMD-77-43: Washington, IV.

U.S. Geological Survey, 1976, Hydrologic studies of the U.S. Geological Survey related to coal development in Colorado: U.S. Geological Survey Open-File Report 76-549, 22 p.

Walters, A., 1868, The coal deposits of Boulder County: American Journal Mineralology, v. 4 p. 242.

Whiteside, F. W., 1912, Coal measures of the Front Range of the Rocky Mountains in Colorado: University of Colorado Journal of Engineering, no. 8 p. $50-55$.

Wood, G. H., Jr., compiler, 1977, National coal resource investigations of the United States Geological Survey: U.S. Geological Survey Open-File Report 77-763, 53 p.

\section{Climate}

Alyea, J. D., , Climatological summary, Rawlins, Wyoming: U.S. Weather Bureau, Climatography of the United States, no. 20-48, $2 \mathrm{p}$.

Hansen, W. R., Chronic, John, and Matelock, John, 1978, Climatology of the Front Range Urban Corridor and vicinity, Colorado: U.S. Geological Survey Professional Paper 1019, $59 \mathrm{p}$.

McCain, J. F., Hoxit, L. R., Maddox, R. A., Chappel, C. F., and Caracena, Fernando, 1979, Meterology and hydrology of Big Thompson River and Cache la Poudre River basins, in, Storm and flood of July 31-August 1, 1976, in the Big Thompson River: U.S. Geological Survey Professional Paper 1115-A, p. 1-85.

Miller, J. F., and Frederick, R. H., and Tracey, R. J., 1973, Precipitation-frequency Atlas of the Western United States, v. 2-Wyoming, v. 3-Colorado: U.S. National Oceanic and Atmospheric Administration, NOAA Atlas 2.

National Oceanic and Atmospheric Administration, (1980), Climatological data, annual summary, Wyoming, 1979 , v. 84 , no. 13,16 p.

U.S. Weather Bureau, 1958, Climatic summary of the United States-supplement for 1931 through 1952: Wyoming, v. 41, $44 \mathrm{p}$.

1965, Climatic summary of the United States, supplement for 1951 through 1960: Climatography of the United States, Wyoming, 
no. $86-42,77$ p.

U.S. Weather Bureau, 1931, Climatic summary of the United States, from the establishment of the stations to 1930, inclusive, Section 14, southeastern Wyoming: U.S. Department of Agriculture, p. 1-18.

Wyoming Water Planning Commission, 1970, Average annual precipitation as of 1965 in Water related land resources of the Green River basin, Wyoming: Cheyenne, Wyoming State Engineer, Water Planning Commission Report no. 3, p. 21.

\section{Geology}

Bastin, E. S., and Hill, J. M., 1917, Economic geology of Gilpin County and adjacent parts of Clear Creek and Boulder Counties, Colorado: U.S. Geological Survey Professional Paper 94, $376 \mathrm{p}$.

Beckwith, R. H., 1938, Structure of the southwest margin of the Laramie basin, Wyoming: Geological Society of America Bulletin, v. 49, no. 10 , scale $1: 48,000$, pl. 1 , scale $1: 62,500$.

Bradley, W. B., 1951, Geology between Little Thompson River and Carter Lake, Larimer County, Colorado: Golden, Colorado School of Mines, M.S. Thesis, 69 p.

Brandt, A. R., and White, J. L., 1907, Geology of a portion of Platte Canyon quadrangle: Golden, Colorado School of Mines, Senior Paper, 2 maps (no scale).

Broin, T. L., 1952, Geology of the Owl CanyonBelvue area, Larimer County, Colorado: Boulder, University of Colorado, M.A. Thesis, $66 \mathrm{p}$.

1956, Limestones and evaporites of the Lykins Formation, Front Range of Colorado: Geological Society of America Bulletin, v. 67, no. 12 , pt. 2 , p. 1791.

1957, Stratigraphy of the Lykins Formation of eastern Colorado: Boulder, University of Colorado, Ph.D. Thesis, 201 p.

Brown, C. L., Clapp, L. P., and Whitehouse, H. D., 1908, Topographical and geological survey of a portion of Platte Canyon quadrangle: Golden, Colorado School of Mines, Senior Paper, $20 \mathrm{p}$.

Brown, R. W., 1943, Cretaceous-Tertiary boundary in the Denver basin, Colorado: Geological Society of America Bulletin, v. 54, p. 65-86. 1949, Paleocene deposits of the Rocky Moun- tains and plains: U.S. Geological Survey General Mineral Resources Map, scale 1:1,000,000.

Butler, C. R., 1950, Structure of Post-Cambrian formations in the vicinity of Coal Creek, Colorado: Boulder, University of Colorado, M.S. Thesis, $44 \mathrm{p}$.

Chronic, Feliche, and Chronic, John, 1974, Bibliography and index of geology and hydrology, Front Range Urban Corridor, Colorado: U.S. Geological Survey Bulletin 1306, $102 \mathrm{p}$.

Clement, J. M., and Dotton, G. L., 1970, A chronicle of exploration in South Park basin, Park County, Colorado: The Mountain Geologist, Rocky Mountain Association of Geologists, v. 7, no. 3, p. 205-216.

Cotton, R. B., and Anderson, L. W., 1977, Preliminary geologic map of the Erie quadrangle, Boulder, Weld, and Adams Counties, Colorado: U.S. Geological Survey Miscellaneous Field Studies Map MF-882, scale $1: 24,000$.

Darton, N. H., Siebenthal, E. E., and Blackwelder, Eliot, 1910, Description of the LaramieSherman quadrangles, Wyoming: U.S. Geological Survey Geologic Atlas, Folio 173, scale 1:125,000.

Denson, N. M., and Bergendahl, M. H., 1961, Middle and upper Tertiary rocks of southeastern Wyoming and adjoining areas, in, Short papers in the geologic and hydrologic sciences, Article 209: U.S. Geological Survey Professional Paper 424-C, p. 168.

Desborough, G. A., Raymond, W. H., and Soule, Courtney, 1970, Placer gold of unique fineness in Douglas and Elbert Counties, Colorado, in Geological Survey Research 1970: U.S. Geological Survey Professional Paper 700-D, p. 134.

Ebens, R. J., and Shacklette, H. T., 1982, Geochemistry of some rocks, mine spoils, stream sediments, soils, plants, and waters in the Western Energy Region of the conterminous United States: U.S. Geological Survey Professional Paper 1237, 173 p.

Eggler, D. H., 1968, Virginia Dale Precambrian ring Dike complex, Colorado-Wyoming: Geological Society of American Bulletin, v. 79, no. 11 , pl. 3 .

Ettinger, M., 1964, Geology of the Hartsel area, 
South Park, Park County, Colorado: The Mountain Geologist, Rocky Mountain Association of Geologist, v. 1, no. 3, p. 127-132.

Finley, E. A., Dobbin, C. E., and Richardson, E. E., 1955, Preliminary structure contour map of the Colorado plains: U.S. Geological Survey Oil and Gas Investigations Map, OM-176.

Gable, D. J., 1980, The Boulder Creek batholith, Front Range Colorado: U.S. Geological Survey Professional Paper 1101, 88 p.

Girty, G. H., 1903, The Carboniferous formations and faunas of Colorado: U.S. Geological Survey Professional Paper 16, 546 p.

Harrison, J. E., and Moench, R. H., 1961, Joints in Precambrian rocks, Central City-Idaho Springs area, Colorado: U.S. Geological Survey Professional Paper 374-B, p. 1-14.

Harrison, J. E., and Wells, J. D., 1959, Geology and ore deposits of the Chicago Creek area, Clear Creek County, Colorado: U.S. Geological Survey Professional Paper 319, 92 p.

Hawley, C. C., and Wobus, R. A., 1977, General geology and petrology of the Precambrian cryatalline rocks, Park and Jefferson Counties, Colorado: U.S. Geological Survey Professional Paper 608-B, p. 1-77.

Henderson, J., 1903, The overturns of the Denver basin: Journal of Geology, v. 2, p. 584-588.

Hershey, L. A., and Schneider, P. A., Jr., 1972, Geologic map of the lower Cache la Poudre River basin, north-central Colorado: U.S. Geological Survey Miscellaneous Geologic Investigations Map I-687, scale 1:62,000.

Horner, W. P., 1954, The Fox Hills-Laramie contact in the Denver basin: Boulder, University of Colorado, M.A. Thesis, $62 \mathrm{p}$.

Hunter, Z. M., 1955, Areal geology of the foothills of the Front Range in northern Colorado: Geological Society of America Bulletin, v. 66, p. 1677.

Irwin, Dennis, 1978, ed., Subsurface cross sections of Colorado: Denver, Rocky Mountain Association of Geologists Special publication no. 2, $39 \mathrm{p}$.

Johnson, J. F., 1935, Geology of the Marshall district, Boulder County, Colorado: Boulder, University of Colorado, M.A. Thesis, 14 p.

King, P. B., 1969, The tectonics of North America-A discussion to accompany the tectonic map of North America: U.S. Geological Survey Professional Paper 628, 94 p.
Kirkham, R. M., O'Leary, W. O., and Warner, J. W., 1980, Hydrogeologic and stratigraphic data pertinent to uranium mining, Cheyenne basin, Colorado: Denver, Colorado Geological Survey, Information Series 12, $31 \mathrm{p}$.

Kittleman, L.O., 1956, The Post-Laramie sediments of the Denver-Colorado Springs Region, Colorado: Boulder, University of Colorado, M.S. Thesis, 127 p.

Kline, M. A., Jr., 1956, The structure and stratigraphy of Cretaceous rocks in northeastern Larimer County, Colorado: Golden, Colorado School of Mines, M.S. Thesis, $131 \mathrm{p}$.

Konikow, L. F., 1975, Hydrogeological maps of the alluvial aquifer in and adjacent to the Rocky Mountain Arsenal, Colorado: U.S. Geological Survey Open-File Report 74-342, scale $1: 48,000$.

Lakes, Arthur, 1902, South Park, Colorado-A description of its geology and economic resources in gold, silver, lead, coal, and oil: Mines and Minerals, v. 23, p. 78-79.

1905, Disturbances and other pecularities of the northeastern coal field of Colorado between Ralston Creek and Boulder: Mining Reporter, v. 51, p. 326-328.

Lee, F. T., Nichols, T. C., Jr., and Abel, J. F., Jr., 1969, Some relations between stress, geologic structure, and underground excavation in a metamorphic rock mass west of Denver, Colorado, in Geological Survey Research 1969: U.S. Geological Survey Professional Paper 650-C, p. C127.

Lowry, M. E., and Crist, M. A., 1967, Geology and ground-water resources of Laramie County, Wyoming: U.S. Geological Survey WaterSupply Paper 1834.

Machette, M. N., 1975, Geologic map of the Lafayette quadrangle, Adams, Boulder, and Jefferson Counties, Colorado: U.S. Geological Survey Miscellaneous Field Studies Map MF-656, scale 1:24,000.

Maughan, E. K., 1963, Mississippian rocks in the Laramie Range, Wyoming, and adjacent areas, in Short papers in geology and hydrology, Article 66: U.S. Geological Survey Professional Paper 475-C, p. C23.

McCoy, A. W. III, 1953, Tectonic history of the Denver basin: American Association Petroleum Geologist Bulletin, v. 37, no. 8, August 1953, p. 1873-1895. 
McLaughlin, T. G., 1946, Geology and groundwater resources of parts of Lincoln, Elbert, and El Paso Counties, Colorado, with special reference to Big Sandy Creek Valley above Limon: Denver, Colorado Water Conservation Board, Ground Water Series, Bulletin 1, 139 p.

Pearl, R. H., 1974, Geology of ground-water resources in Colorado-an introduction: Denver, Colorado Geological Survey, Special Publication 4, $47 \mathrm{p}$.

Rapp, J. R., Warner, D. A., and Morgan, A. M., 1953, Geology and ground-water resources of the Egbert-Pine Bluffs-Carpenter area, Laramie County, Wyoming: U.S. Geological Survey Water-Supply Paper 1140, pl. 1, scale 1:93,750.

Scott, G. R., 1972, Geologic map of the Morrison quadrangle, Jefferson County, Colorado: U.S. Geological Survey Miscellaneous Geological Investigations Map I-428, scale 1:24,000.

Soister, P. E., 1972, Geologic map of the Peoria quadrangle, Arapahoe and Adams Counties, Colorado: U.S. Geological Survey Geological quadrangle map GQ-875, scale 1:24,000.

1972, Preliminary geologic map and lignite deposits of the Strasburg northwest quadrangle, Arapahoe and Adams Counties, Colorado: U.S. Geological Survey open-file report, Geologic map, 2 sheets graphic coal sections, scale 1:24,000.

Taylor, R. B., and Sims, P. K., 1962, Precambrian gabbro in the central Front Range, Colorado, in Short papers in geology, hydrology, and topography, Article 154: U.S. Geological Survey Professional Paper 450-D, p. 118.

Tooker, E. W., 1963, Altered wall rocks in the central part of the Front Range mineral belt, Gilpin and Clear Creek Counties, Colorado: U.S. Geological Survey Professional Paper 439, $102 \mathrm{p}$.

Tourtelot, H. A., 1973, Regional geochemical investigations, Front Range Urban Corridor, Colorado: Geological Society of America Abstracts with Programs, v. 5 , no. 6 , p. 520-521.

Trimble, D. E., 1975, Geologic map of the Niwot quadrangle, Boulder County, Colorado: U.S. Geological Survey Geological quadrangle map GQ-1229, scale 1:24,000.

Tweto, O. L., 1964, Geology, in Mineral and water resources of Colorado, U.S. Congress, 88th, 2nd session, Government Printing Office, p. 11-27.
1975, Laramide (late Cretaceous-early Teriary) orogeny in the Southern Rocky Mountains, in Curtis, B. F., ed., Cenozoic history of the Southern Rocky Mountains: Boulder, Geologic Society of America Memoir 144, p. 1-44.

VanHorn, Richard, 1976, Geology of the Golden quadrangle, Colorado: U.S. Geological Survey Professional Paper 872, 116 p.

Varnes, K. L., and Dolton, G. L., 1982, Estimated areas and volumes of sedimentary rock in the United States by province-statistical background data for U.S. Geological Survey Circular 860: U.S. Geological Survey Open-File Report 81-666C, $11 \mathrm{p}$.

Waage', K. M., 1955, Dakota group in northern Front Range foothills, Colorado: U.S. Geological Survey Professional Paper 274-B, p. $15-51$.

Wells, J. D., Sheridan, D. M., and Albee, A. L., 1961, Metamorphism and structural history of the Coal Creek area, Front Range, Colorado, in Short papers in the geologic and hydrologic sciences, Article 196: U.S. Geological Survey Professional Paper 424-C, p. 127.

Welsch, F., 1969, The Geology of the Castle Rock area, Douglas County, Colorado: Golden, Colorado School of Mines, M.S. Theis, 93 p.

Young, R. G., 1960, Dakota Group of the Colorado Plateau: American Association of Petroleum Geologists Bulletin, v. 44, no. 2, p. 156-194.

\section{Surface Water}

Black, P. E., and others, 1959, Watershed analysis of the North Fork of the Cache la Poudre River, Larimer County, Colorado, and Albany County, Wyoming: Ft. Collins, Colorado State University, Watershed Management Paper 209, 1 sheet, scale 1:250,000.

Boyd, David, 1897, Irrigation near Greeley, Colorado: U.S. Geological Survey Water-Supply Paper 9, $90 \mathrm{p}$.

Hall, D. C., and Duncan, A. C., 1980, Hydrologic data from upper Grange Hall Creek basin, Northglenn, Adams County, Colorado: U.S. Geological Survey Open-File Report 80-578, $132 \mathrm{p}$.

U.S. Geological Survey, 1961, Floods at Boulder, Colorado: U.S. Geological Survey Hydrologic Investigations Atlas HA-41, scale 1:6,000. 


\section{Ground Water}

Ahrens, T. P., 1950, Ground-water investigation, Granby pump canal, Colorado Big Thompson project, Colorado: U.S. Bureau of Reclamation, Geology Report no. G-107, 48 p.

Babcock, H. M., Bjorklund, L. J., and Kister, L. R., 1956, Ground-water geology of parts of Laramie and Albany Counties Wyoming and Weld County, Colorado: U.S. Geological Survey Water-Supply Paper 1367, 61 p.

Brookman, J. A., 1968, Colorado ground-water levels, spring, 1968: Colorado State University Experimental Station, CER67-68JB2.

1969, Colorado ground-water levels, spring, 1969: Colorado State University Engineering Research Center, CER68-69JB39.

Crist, M. A., and Borchert, W: B., 1972, The ground-water system in south-eastern Laramie County, Wyoming: U.S. Geological Survey open-file report, scale 1:48,000.

Eakins, Wynn, 1981, Geophysical logs from the 1981 water well logging program, Castle Rock $1 / 2^{\circ} \times 1^{\circ}$ quadrangle: Denver, Colorado Geological Survey Open-File Report 81-8, 93 p.

Florquist, B. A., 1972, Exploration and development procedures for ground water in fractured crystalline rocks of the Colorado Rockies: American Geophysics Union, Transactions, v. 53 , no. 11 , p. 980 .

Goddard, K. E., 1978, Availability and quality of ground water in the Lake George area, southeastern Park County, Colorado: U.S. Geological Survey Water Resources Investigations 78-50, 28 p.

Hall, D. C., Boyd, E. L., and Cain, Doug, 1979, Hydrogeologic data for wells, springs and streams in Boulder County, Colorado: U.S. Geological Survey Open-File Report 79-979, $106 \mathrm{p}$.

LaRocque, G. A., Jr., 1966, General availability of ground water and depth to water level in the Missouri River basin: U.S. Geological Survey Hydrologic Investigation Atlas HA-217, scale $1: 2,500,000$.

Lowry, M. E., 1966, The White River Formation as an aquifer in southeastern Wyoming and adjacent parts of Nebraska and Colorado, in Geological Survey Research 1966: U.S. Geological Survey Professional Paper 550-D, p. 217.
Taylor, O. J., 1978, Summary appraisals of the nation's ground-water resources-Missouri River basin region: U.S. Geological Survey Professional Paper 813-Q, p. 1-41.

White, N. F., and Sunada, D. K., 1966, Groundwater quality study of Severance basin, Weld County, Colorado: Ft. Collins, Colorado State University, Department of Civil Engineering, CER66NFW-DKS5, 29 p.

Wyoming Department of Environmental Quality, 1980, in Quality standards for Wyoming ground waters, Water quality rules and regulations: Chapter VIII, $13 \mathrm{p}$.

\section{Water Resources}

Klein, J. M., Goddard, K. E., and Livingston, R. K., 1978, Appraisal of the water resources of Park and Teller Counties, Colorado: Colorado Water Conservation Board, Water Resources Circular no. 36,79 p.

Lowry, M. E., Rucker, S. J., IV, and Wahl, K. L., 1973, Water resources of the Laramie, Shirley, Hanna basins and adjacent areas, southeastern Wyoming: U.S. Geological Survey Hydrologic Investigations Atlas HA-471, scale 1:250,000.

Millon, E. R., 1970, Water pollution, Red Feather Lakes area (Larimer County), Colorado: Ft. Collins, Colorado State University, M.S. Thesis, $78 \mathrm{p}$.

Robinson, G. D., and Spieker, A. M., 1978, editors, Nature to be commanded. ...: U.S. Geological Survey Professional Paper 950, 95 p.

\section{Land Use}

Anderson, J. R., Hardy, E. E., Roach, J. T., and Witmer, R. E., 1976, A land use and land cover classification system for use with remote sensor data: U.S. Geological Survey Professional Paper 964, $28 \mathrm{p}$.

U.S. Geological Survey, 1980, Land use and land cover, 1972-76, Greeley Quadrangle, Colorado; Wyoming: U.S. Geological Survey Land Use map L-188, scale 1:250,000.

\section{Soils}

Branson, F. A., Miller, R. F., and McQueen, I. S., 1961, Soil-water availability and use of grassland on adjacent stoney and shale-derived 
soils in Colorado, in, Short papers in the geologic and hydrologic sciences: Professional Paper 424-C, Article 239, p. 251.

Bunker, C. M., and Bush, C. A., 1968, Radio element composition of surface soil in Adams County, Colorado, in, Geological Survey Research 1968: U.S. Geological Survey Professional paper 600-B, p. 71.

Gerrard, A. J., 1981, Soils and landforms-An integration of geomorphology and pedology, London, George Allen and Unwin., 219 p.
U.S. Department of Agriculture, 1975, Soil toxnomy, a basic system of soil classification for making and interpreting soil surveys: U.S. Department of Agriculture Handbook 436, $754 \mathrm{p}$.

1974-75, 1977, 1979-80, Wyoming soil interpretations record, Blazon, Corpening, Delphill, Fossilon, Freddle, Garsid, Hatermus, Havre, McFadden, Ryark, Simmont, Sinkson, Starley, Thermopolis, Ulric, and Yetull series: U.S. Soil Conservation Service, 1 p. 